2003 Wastewater Land Application Site Performance Reports for the Idaho National Engineering and Environmental Laboratory

February 2004 


\section{Wastewater Land Application Site Performance Reports for the Idaho National Engineering and Environmental Laboratory}

Central Facilities Area Sewage Treatment Plant Idaho Nuclear Technology and Engineering Center New Percolation Ponds Idaho Nuclear Technology and Engineering Center Sewage Treatment Plant Test Area North/Technical Support Facility Sewage Treatment Plant

February 2004

Idaho National Engineering and Environmental Laboratory

Idaho Falls, Idaho 83415

Prepared for the

U.S. Department of Energy

Assistant Secretary for Environmental Management

Under DOE Idaho Operations Office

Contract DE-AC07-99ID13727 


\begin{abstract}
The 2003 Wastewater Land Application Site Performance Reports for the Idaho National Engineering and Environmental Laboratory describe site conditions for the facilities with State of Idaho Wastewater Land Application Permits. Permit-required monitoring data are summarized, and permit exceedences or environmental impacts relating to the operation of the facilities during the 2003 permit year are discussed.
\end{abstract}




\section{SUMMARY}

The 2003 Wastewater Land Application Site Performance Reports for the Idaho National Engineering and Environmental Laboratory (INEEL) describe site conditions for the following facilities as required by the applicable State of Idaho Wastewater Land Application Permits (WLAPs):

- Central Facilities Area (CFA) Sewage Treatment Plant (STP), Permit Number LA-000141-01

- Idaho Nuclear Technology and Engineering Center (INTEC) New Percolation Ponds, Permit Number LA-000130-03

- INTEC STP, Permit Number LA-000115-02

- Test Area North/Technical Support Facility (TAN/TSF) STP, Permit Number LA-000153-01.

These reports contain the following information:

- Site description

- Facility and system description

- Status of special compliance conditions

- Permit-required monitoring data

- Discussions of environmental impacts by the facilities.

The CFA report covers from December 1, 2002, through November 30, 2003, while the INTEC and TAN reports cover from November 1, 2002, through October 31, 2003. These reporting periods are based on the individual facility permits.

The original WLAP issued for the CFA STP expired August 7, 1999. A renewal application was submitted February 9, 1999. A letter authorizing the continued operation of the CFA STP under the original WLAP was issued by the Idaho Department of Environmental Quality (DEQ) on September 18, 2000.

The original WLAP issued for the INTEC STP expired September 17, 2000. A renewal application was submitted during March 2000. Authorization to continue to operate the INTEC STP was received in January 2001. The initial WLAP for the INTEC New Percolation Ponds was issued on September 10, 2001, and amended on March 28, 2002.

The original WLAP issued for the TAN/TSF STP expired on May 8, 2001. The renewal application for this facility was submitted on November 2, 2000. Authorization to continue to operate the TAN/TSF STP was received from DEQ on July 12, 2001. 
Authorization by DEQ to continue to operate the CFA, INTEC, and TAN/TSF STPs is in effect until new WLAPs are issued for each of these facilities.

During the 2003 permit year, approximately 5.98 million gallons of treated wastewater was land applied in the irrigation area at CFA. Soil and weather conditions combined with the relatively low volume of wastewater applied during the 2003 permit year resulted in a very low leaching loss ( $0.10 \mathrm{in}$.) for the year, compared to the permit limit of 3 in. per year. As a result, land application of wastewater appeared to have negligible impact on soils and groundwater. While sodium adsorption ratios were elevated relative to preapplication sodium adsorption ratios, they remain well below those in soils classified with sodium problems.

Evaluations conducted to date regarding the high nitrate + nitrite concentrations detected in groundwater near the new CFA STP determined that the new STP was not the likely source. Because the source is not believed to be the STP, sampling of these wells in not required under the CFA STP WLAP. However, Waste Area Group (WAG) 4 (under the INEEL Federal Facilities Agreement/ Consent Order) will continue to monitor the groundwater nitrate + nitrite concentrations.

The INTEC New Percolation Ponds became operational on August 26, 2002, when wastewater from CPP-797 was diverted from the existing INTEC Percolation Ponds, which were then removed from service. During the 2003 permit year, daily and annual flow volume to the New Percolation Ponds remained within permit limits. The permit for the New Percolation Ponds does not specify concentration limits for the effluent to the ponds. However, in order to aid in monitoring plant efficiency, effluent concentrations were compared to the groundwater quality standards. During permit year 2003, when comparing the effluent concentrations to the groundwater quality standards as an indicator of plant efficiency, only total dissolved solids (TDS) and chloride fell above the standards (during 4 months of the permit year). However, because no permit limits are set for the effluent, these levels do not reflect permit noncompliances. During these same 4 months, the sodium concentrations in the effluent were also high. High concentrations of TDS, chloride, and sodium in the service waste effluent are usually indicative of a problem with the CPP-606 water treatment system. During the permit year, several evaluations were conducted in support of a project to upgrade the current INTEC water treatment system. These evaluations included a survey of the treated water demands, water quality requirements, and candidate conservation measures. Several design options to upgrade the water treatment system are currently being evaluated.

The concentrations of aluminum and manganese in April 2003 and of aluminum, iron, and manganese in October 2003 in aquifer well ICPP-MON-A-166 were above the applicable permit limits. Aluminum and iron concentrations were also above the applicable permit limits in April 2003 and October 2003 in well ICPP-MON-V-200. The concentrations of aluminum, iron, and manganese in the background aquifer well (ICPP-MON-A-167) also exceeded the applicable groundwater quality standards in both April 2003 and October 2003. These elevated concentrations are not believed to be related to 
operational activities at the INTEC New Percolation Ponds. Concentrations of these parameters in the effluent are well below their applicable groundwater quality standards. One possible explanation may be that the wells were insufficiently developed during construction activities. Another possible explanation is that the annular seals were placed incorrectly, thus allowing bentonite slurry to affect the water quality. Prior to each sampling event, additional purging was performed on these wells to try to remove any residual slurry that may be in the wells as a result of the well construction activities. In addition, filtered samples were collected along with the permit-required unfiltered samples during the October 2003 sampling event for each of these wells. The filtered sample concentrations were below the groundwater quality standards and were significantly less than the concentrations in the unfiltered samples. The filters have been submitted to the laboratory for additional analysis to try to verify the source of the aluminum, iron, and manganese in these wells.

Well ICPP-MON-V-200 also exceeded the permit limit for TDS in October 2003. This is expected to be directly related to the TDS concentrations in the effluent. Although not exceeding the permit limits, chloride and sodium concentrations have also increased significantly in this well.

INTEC STP effluent flow volumes and groundwater concentrations were all within permit limits. Both total nitrogen and total suspended solids concentrations in the effluent exceeded the permit limit $(20 \mathrm{mg} / \mathrm{L}$ and $100 \mathrm{mg} / \mathrm{L}$, respectively) 1 month during the 2003 permit year. Numerous maintenance and operational corrective actions have been implemented in the past to manage the total nitrogen concentration in the effluent. In 2003, a proposal to expand the operations associated with the New Percolation Ponds and reroute treated sanitary wastewater from the STP to the New Percolation Ponds was submitted to DEQ. As a result of this operation, the infiltration trenches associated with the STP would be closed and the WLAP for the STP would be terminated.

Concentrations of permit-required parameters in groundwater samples collected from the aquifer compliance well (USGS-052) near the INTEC STP were all within permit limits during 2003. Total and fecal coliform were detected in the perched water well (ICPP-MON-PW-024) in October 2003. Fecal coliform consists of various genera and species of coliform that are specifically associated with human and animal wastes. The treatment processes at the INTEC STP do not include disinfecting the wastewater. Therefore, the source of coliform bacteria found in well ICPP-MON-PW-024 is probably the INTEC STP effluent.

The TAN/TSF effluent flow volumes and concentrations were within permit limits. Elevated iron concentrations historically have been detected in the TAN WLAP monitoring wells. Due to this, a corrosion evaluation was performed in 2000. The evaluation confirmed that the riser pipes for these wells were significantly corroded. The riser pipes attached to the dedicated pumps were replaced with stainless steel riser pipes in all four TAN WLAP monitoring wells during August 2001. Since then, the iron concentrations in three of the wells (TAN-13A, TANT-MON-A-001, and TANT-MON-A-002) have decreased. The iron concentrations in these three wells were below the groundwater quality standard in both April 2003 and October 2003. Iron concentrations in the remaining well (TAN-10A) exceeded the permit limit in both April 2003 and October 2003. 
Of the four TAN WLAP wells, TAN-10A is cased with carbon steel well casing and video logging shows that the casing is corroded most of the way to the water table. The iron concentrations in TAN-10A increased after the riser pipes were replaced, and the October 2002 iron concentrations for TAN-10A were the highest reported for the four wells. The condition of the well casing, coupled with the residual effects from replacing the galvanized riser pipe, may have resulted in the increased iron concentrations in TAN-10A.

Fecal coliform was absent in all TAN/TSF samples and wells during the 2003 permit year. In addition, total coliform was absent in all wells during April 2003. However, total coliform was identified in the October 2003 samples from monitoring wells TANT-MON-A-001 (upgradient, background well), TANT-MON-A-002 (compliance well), and TAN-13A (compliance well). The groundwater standard for total coliform is 1 colony/100 $\mathrm{ml}$. The total coliform in wells TANT-MON-A-001, TANT-MON-A-002, and TAN-13A were 4 colonies/100 mL, 17 colonies $/ 100 \mathrm{~mL}$ ( 26 colonies/100 ml, duplicate), and 72 colonies/100 ml, respectively. The coliform species identified by the laboratory was Hafnia alvei in wells TANT-MON-A-001 and TANT-MON-A-002. Two coliform species, Hafnia alvei and Serratia marcescens were identified in well TAN-13A. The TAN/TSF Disposal Pond effluent contains total coliform bacteria; however, it is unlikely the coliform detected in wells TANT-MON-A-001 and TANT-MON-A-002 was the result of the Disposal Pond effluent. TANT-MON-A-001 is the background well and is not influenced by the Disposal Pond. TANT-MON-A-002 is west/southwest of the Disposal Pond, and groundwater flows at TAN are primarily to the south or southeast; therefore, it is unlikely that bacteria could be transported into the well without significant transverse dispersivity in the vadose zone. For well TAN-13A, the October 2003 detection is the first time that coliform has been detected in this well since 1996. Because well TAN-13A is located southeast of the disposal pond, it is possible that the coliform in the effluent discharged to the pond has affected this well. However, fecal coliform is also present in the effluent but was not detected in TAN-13A. There are many possible sources for the total coliform detected in the samples from these three wells. Further evaluation will be required to try and identify the specific source of the coliform contamination. If the source can be identified, then appropriate corrective actions can be taken.

Four monitoring wells associated with the TAN/TSF facility have been approved for a "no-longer-contained-in" determination from DEQ. These wells include two monitoring wells associated with the Wastewater Land Application Permit (TAN-10A and TAN-13A) and wells TAN-27 and TSFAG-05. During the 2003 permit year, no purge water was discharged to the TAN/TSF Disposal Pond as a result of sampling these wells. 


\section{CONTENTS}

ABSTRACT

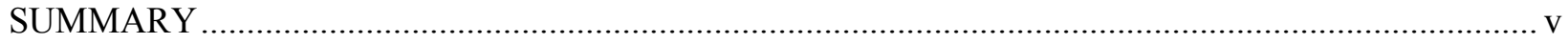

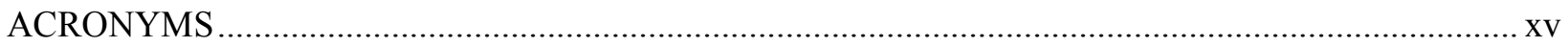

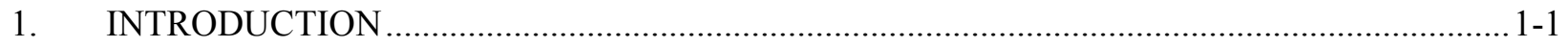

1.1 Idaho National Engineering and Environmental Laboratory Site Description .................... 1-2

1.2 Liquid Effluent Monitoring Program .................................................................... 1-4

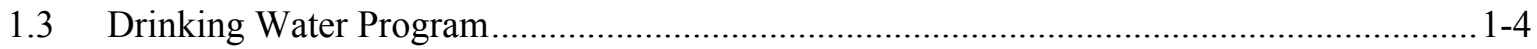

1.4 Groundwater Monitoring Program........................................................................... 1-4

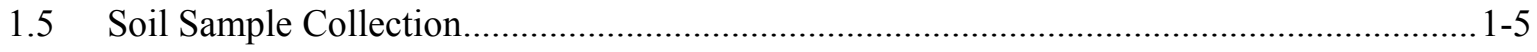

2. CENTRAL FACILITIES AREA SEWAGE TREATMENT PLANT DATA SUMMARY

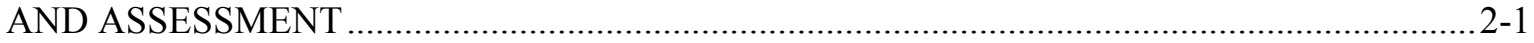

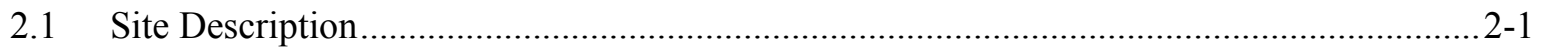

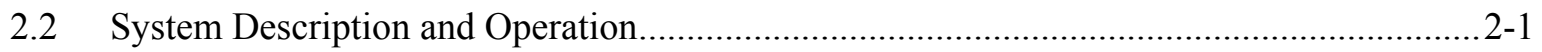

2.3 Status of Special Compliance Conditions …............................................................... 2-3

2.4 Influent and Effluent Monitoring Results ................................................................ 2-3

2.4.1 Flow Volumes and Loading Rates........................................................................2-5

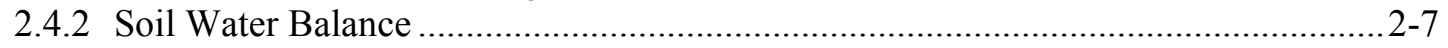

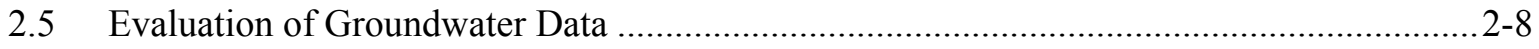

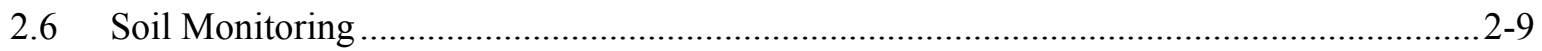

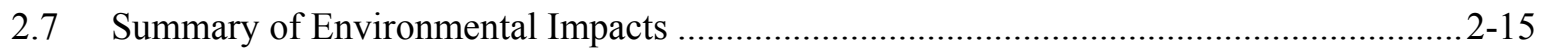

3. IDAHO NUCLEAR TECHNOLOGY AND ENGINEERING CENTER NEW

PERCOLATION PONDS DATA SUMMARY AND ASSESSMENT ....................................... $3-1$

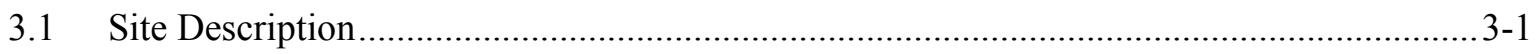

3.2 System Description and Operation.......................................................................... $3-1$

3.3 Status of Special Compliance Conditions .................................................................... 3-4

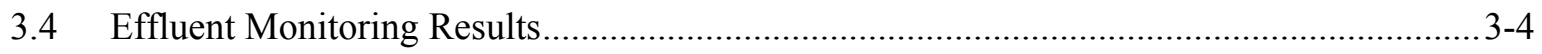

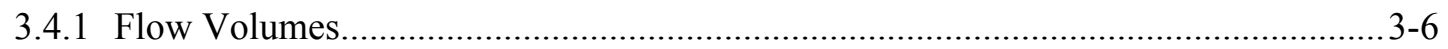


3.5 Evaluation of Water Quality Testing for the Weapons Range ......................................... 3-6

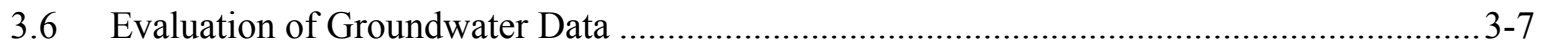

3.7 Summary of Environmental Impacts …................................................................ $3-15$

4. IDAHO NUCLEAR TECHNOLOGY AND ENGINEERING CENTER SEWAGE

TREATMENT PLANT DATA SUMMARY AND ASSESSMENT …........................................4-1

4.1 System Description and Operation......................................................................... $4-1$

4.2 Status of Special Compliance Conditions .................................................................... 4-2

4.3 Influent and Effluent Monitoring Results .............................................................. 4-3

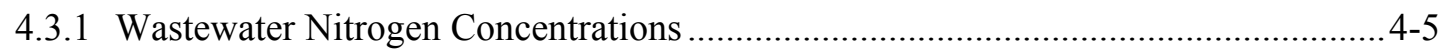

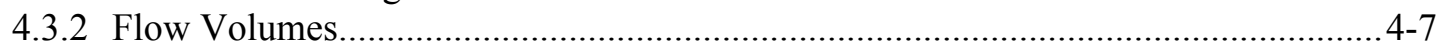

4.4 Evaluation of Groundwater Data …........................................................................ $4-9$

4.5 Summary of Environmental Impacts ….................................................................. 4 -13

5. TEST AREA NORTH/TECHNICAL SUPPORT FACILITY SEWAGE

TREATMENT PLANT DATA SUMMARY AND ASSESSMENT …....................................... $5-1$

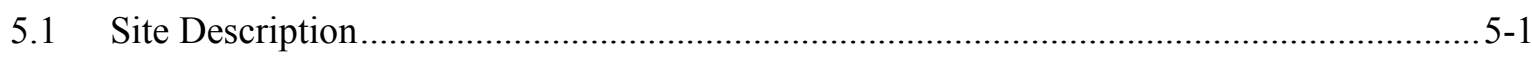

5.2 System Description and Operation....................................................................... $5-1$

5.3 Status of Special Compliance Conditions ….............................................................. $5-2$

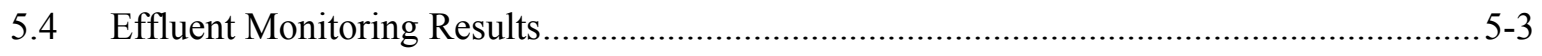

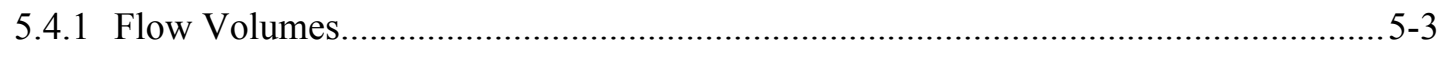

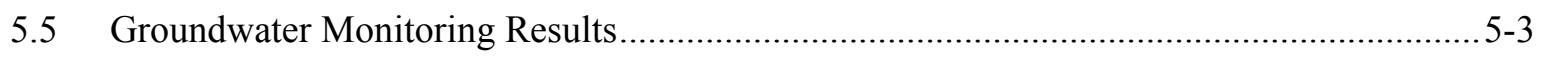

5.6 Summary of Environmental Impacts ….............................................................. $5-11$

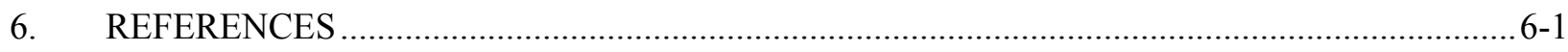

Appendix A - Central Facilities Area Sewage Treatment Plant Daily Influent and Effluent Flow Readings, Sewage Treatment Plant Photographs, and Electronic

Data Files.

Appendix B - Idaho Nuclear Technology and Engineering Center New Percolation Ponds

Daily Effluent Flow Readings and Electronic Data Files.

Appendix C-Idaho Nuclear Technology and Engineering Center Sewage Treatment

Plant Daily Influent and Effluent Flow Readings and Electronic Data Files 
Appendix D-Test Area North/Technical Support Facility Sewage Treatment Plant Daily

Effluent Flow Readings and Electronic Data Files

\section{FIGURES}

1-1. Idaho National Engineering and Environmental Laboratory.................................................... 1-3

2-1. Central Facilities Area Sewage Treatment Plant......................................................................2-2

2-2. Locations of monitoring wells in the vicinity of the Central Facilities Area

Sewage Treatment Plant.

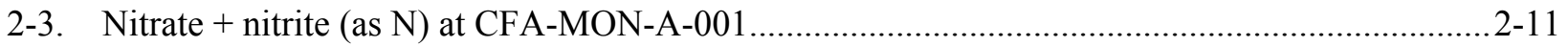

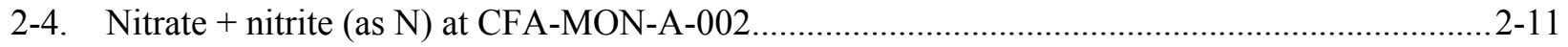

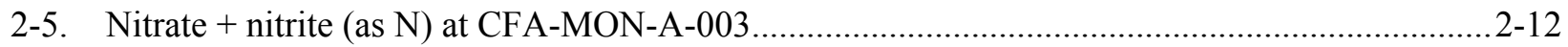

2-6. Central Facilities Area Wastewater Land Application Permit soil monitoring locations.............2-13

3-1. Location of Idaho Nuclear Technology and Engineering Center New Percolation Ponds..............3-2

3-2. Detail of Idaho Nuclear Technology and Engineering Center New Percolation Ponds.................3-3

3-3. Location of Idaho Nuclear Technology and Engineering Center New Percolation Ponds

WLAP monitoring wells

4-1. Idaho Nuclear Technology and Engineering Center Sewage Treatment Plant and rapid infiltration trenches.

4-2. Idaho Nuclear Technology and Engineering Center Sewage Treatment Plant influent (CPP-769) and effluent (CPP-773) total nitrogen concentrations.

4-3. Locations of Idaho Nuclear Technology and Engineering Center Sewage Treatment Plant WLAP monitoring wells

4-4. Total nitrogen concentrations in Sewage Treatment Plant effluent, ICPP-MON-PW-024, and USGS-052.

5-1. Test Area North/Technical Support Facility Sewage Treatment Plant and Wastewater Disposal Pond.

5-2. Locations of Test Area North/Technical Support Facility WLAP monitoring wells.

5-3. Total dissolved solids concentration from Test Area North/Technical Support Facility

Well TAN-10A and the effluent (TAN-655).

A-1. Central Facilities Area Sewage Treatment Plant, 1995 (95-627-7-4) ........................................ A-10

A-2. Central Facilities Area Sewage Treatment Plant, 1996 (96-174-9-8) ...................................... A-11

A-3. Central Facilities Area Sewage Treatment Plant, 1997 (97-620-5-14) ..................................... A-12 
A-4. Central Facilities Area Sewage Treatment Plant, 1998 (98-454-11-6) ...................................... A-13

A-5. Central Facilities Area Sewage Treatment Plant, 1999 (99-344-10-9) ...................................... A-14

A-6. Central Facilities Area Sewage Treatment Plant, 2000 (00-296-2-2) ....................................... A-15

A-7. Central Facilities Area Sewage Treatment Plant, 2002 (PD020741-02) .................................... A-16

A-8. Central Facilities Area Sewage Treatment Plant, 2003 (PD030339-01) .................................... A-17

\section{TABLES}

1-1. Idaho National Engineering and Environmental Laboratory facilities and permit numbers...........1-1

2-1. Central Facilities Area Sewage Treatment Plant influent water quality data from lift station (WW-014101)

2-2. Central Facilities Area Sewage Treatment Plant effluent water quality data prior to pivot (WW-014102).

2-3. 2003 removal efficiency percentages for Central Facilities Area Sewage Treatment Plant permit monitoring parameters.

2-4. Central Facilities Area Sewage Treatment Plant flow summaries.

2-5. 2003 hydraulic and nutrient loading rates.

2-6. Central Facilities Area Sewage Treatment Plant monthly water balance for 5.98 MG wastewater applied to the irrigation area.

2-7. Central Facilities Area Sewage Treatment Plant application area soil monitoring results.

3-1. Idaho Nuclear Technology and Engineering Center New Percolation Ponds effluent data (WW-013001)

3-2. Idaho Nuclear Technology and Engineering Center New Percolation Ponds flow summaries. ...... 3-7

3-3. Idaho Nuclear Technology and Engineering Center New Percolation Ponds groundwater quality data from aquifer wells for April and October 2003.

3-4. Idaho Nuclear Technology and Engineering Center New Percolation Ponds groundwater quality data from perched water wells for April and October 2003.

3-5. Preoperational concentrations of TKN, aluminum, iron, and manganese in wells ICPP-MON-A-167 and ICPP-MON-A-166.

4-1. Idaho Nuclear Technology and Engineering Center Sewage Treatment Plant influent data (WW-011501).

4-2. Idaho Nuclear Technology and Engineering Center Sewage Treatment Plant effluent data (WW-011502). 
4-3. Removal efficiency for permit monitoring parameters at the Idaho Nuclear Technology

and Engineering Center Sewage Treatment Plant.

4-4. Idaho Nuclear Technology and Engineering Center Sewage Treatment Plant

flow summaries.

4-5. Monthly flow to each trench......

4-6. Idaho Nuclear Technology and Engineering Center Sewage Treatment Plant groundwater data for April and October 2003.

5-1. Test Area North/Technical Support Facility water data for effluent to the TAN/TSF Disposal Pond (WW-015301).

5-2. Test Area North/Technical Support Facility flow summaries.

5-3. Test Area North/Technical Support Facility Sewage Treatment Plant groundwater data for April and October 2003.

A-1. Central Facilities Area Sewage Treatment Plant daily influent and effluent flows.

A-2. Hydraulic Worksheet from WLAP Data Entry for LA-141-1.XLS

A-3. MU Summary Worksheet from WLAP Data Entry for LA-141-1.XLS

A-4. Soils Worksheet from WLAP Data Entry for LA-141-1.XLS

A-5. Wastewater Worksheet from WLAP Data Entry for LA-141-1.XLS

A-6. Site Summary Worksheet from WLAP Data Entry for LA-141-1.XLS.

B-1. Idaho Nuclear Technology and Engineering Center New Percolation Ponds daily effluent flows.....

B-2. Hydraulic Worksheet from WLAP Data Entry for LA-130-3.XLS B-11

B-3. Groundwater Worksheet from WLAP Data Entry for LA-130-3.XLS B-12

B-4. Wastewater Worksheet from WLAP Data Entry for LA-130-3.XLS B-14

B-5. Site Summary Worksheet from WLAP Data Entry for LA-130-3.XLS. B-16

C-1. Idaho Nuclear Technology and Engineering Center Sewage Treatment Plant influent and effluent flows

C-2. Hydraulic Worksheet from WLAP Data Entry for LA-115-2.XLS C-11

C-3. Groundwater Worksheet from WLAP Data Entry for LA-115-2.XLS C-13

C-4. Wastewater Worksheet from WLAP Data Entry for LA-115-2.XLS C-15

C-5. Site Summary Worksheet from WLAP Data Entry for LA-115-2.XLS. C-17 
D-1. Test Area North/Technical Support Facility Sewage Treatment Plant daily effluent flows .......... D-3

D-2. Hydraulic Worksheet from WLAP Data Entry for LA-153-1.XLS ….................................... D-11

D-3. Groundwater Worksheet from WLAP Data Entry for LA-153-1.XLS ................................... D-12

D-4. Wastewater Worksheet from WLAP Data Entry for LA-153-1.XLS ...................................... D-14

D-5. Site Summary Worksheet from WLAP Data Entry for LA-153-1.XLS.................................... D-17 


\section{ACRONYMS}

BBWI Bechtel BWXT Idaho, LLC

BOD biochemical oxygen demand

CERCLA Comprehensive Environmental Response, Compensation, and Liability Act

CES

CFA

Cascade Earth Sciences, Ltd.

CFR

Central Facilities Area

chemical oxygen demand

d day

DEQ Department of Environmental Quality

EPA Environmental Protection Agency

ESRP eastern Snake River Plain

ESRPA eastern Snake River Plain aquifer

FFA/CO Federal Facilities Agreement/Consent Order

$\mathrm{ft} \quad$ foot

$\mathrm{gal} / \mathrm{d} / \mathrm{ft} \quad$ gallons/day/foot

gpd gallons per day

ICPP Idaho Chemical Processing Plant

IDAPA Idaho Administrative Procedures Act

INEEL Idaho National Engineering and Environmental Laboratory

INTEC Idaho Nuclear Technology and Engineering Center

MG million gallons

$\mathrm{mg} / \mathrm{L} \quad$ milligram per liter

mi mile

$\mathrm{N} \quad$ nitrogen

NE-ID Department of Energy, Idaho Operations Office

$\mathrm{NH}_{3}-\mathrm{N} \quad$ ammonia as nitrogen

$\mathrm{NH}_{4}-\mathrm{N} \quad$ ammonium

NLCI no-longer-contained-in

$\mathrm{NNN} \quad$ nitrate + nitrite as nitrogen

$\mathrm{NO}_{2}-\mathrm{N} \quad$ nitrite as nitrogen

$\mathrm{NO}_{3}-\mathrm{N} \quad$ nitrate as nitrogen

O\&M Operations and Maintenance

OOS out of service

OU Operable Unit

PCS primary constituent standard

RCRA Resource Conservation and Recovery Act

RE removal efficiency

RI rapid infiltration 
ROD Record of Decision

SAR Sodium adsorption ratio

SCS secondary constituent standard

STP Sewage Treatment Plant

TAN Test Area North

TDS total dissolved solids

TKN total Kjeldahl nitrogen

TSF Technical Support Facility

TSS total suspended solids

USGS United States Geological Survey

WAG Waste Area Group

WLAP Wastewater Land Application Permit

WGS Waste Generator Services 


\section{Wastewater Land Application Site Performance Reports for the Idaho National Engineering and Environmental Laboratory}

\section{INTRODUCTION}

The 2003 Wastewater Land Application Site Performance Reports for the Idaho National Engineering and Environmental Laboratory (INEEL) describe site conditions for the facilities listed in Table 1-1 as required by the State of Idaho Wastewater Land Application Permits (WLAPs).

Table 1-1. Idaho National Engineering and Environmental Laboratory facilities and permit numbers.

\begin{tabular}{ll}
\hline \multicolumn{1}{c}{ Facility } & Permit Number \\
\hline Central Facilities Area (CFA) Sewage Treatment Plant (STP) & LA-000141-01 \\
Idaho Nuclear Technology and Engineering Center (INTEC) & LA-000130-03 \\
New Percolation Ponds & \\
INTEC STP & LA-000115-02 \\
Test Area North/Technical Support Facility (TAN/TSF) STP & LA-000153-01 \\
\hline
\end{tabular}

These reports contain the following information:

- $\quad$ Site description

- $\quad$ Facility and system description

- $\quad$ Status of special compliance conditions

- $\quad$ Permit-required monitoring data

- $\quad$ Discussions of environmental impacts by the facilities.

The Central Facilities Area (CFA) report covers from December 1, 2002, through November 30, 2003, while the Idaho Nuclear Technology and Engineering Center (INTEC) and Test Area North/Technical Support Facility (TAN/TSF) reports cover from November 1, 2002, through October 31,2003 . These reporting periods are based on the individual facility permits.

The original WLAP issued for the CFA Sewage Treatment Plant (STP) expired August 7, 1999 (Green 1994). A renewal application was submitted February 9, 1999 (Bennett 1999). A letter authorizing the continued operation of the CFA STP under the original WLAP was issued September 18, 2000 (Johnston 2000).

The original WLAP issued for the INTEC STP (Green 1995) expired September 17, 2000. A renewal application was submitted during March 2000 (Graham 2000). Authorization to continue operation was received in January 2001 for the INTEC STP (Johnston 2001). The initial WLAP for the INTEC New Percolation Ponds was issued by the Department of Environmental Quality (DEQ) on September 10, 2001 
(Eager 2001), and was amended on March 28, 2002 (Eager 2002). The amended permit is effective as of March 28, 2002, and expires on April 1, 2007. On August 26, 2002, wastewater discharge to the existing Percolation Ponds ceased. The existing Percolation Ponds were permanently taken out of service and will be closed under the Comprehensive Environmental Response, Compensation, and Liability Act (CERCLA) requirements. A letter (Guymon 2002a) requesting cancellation of the WLAP (LA-000130-02) was submitted to DEQ on October 23, 2002. DEQ acknowledged that the existing Percolation Ponds permit was considered ineffective as of November 4, 2002 (Rackow 2002a). Because there are no post-WLAP closure or monitoring requirements for the existing Percolation Ponds or their associated groundwater monitoring wells, WLAP Performance Reports are no longer required for the existing Percolation Ponds.

The original WLAP issued for the TAN/TSF STP expired on May 8, 2001 (Green 1996). A renewal application was submitted on November 2, 2000 (Guymon 2000). Authorization to continue operating the TAN/TSF STP was received in July 2001 (Teuscher 2001).

Operations at all facilities are conducted by Bechtel BWXT Idaho, LLC (BBWI) for the Department of Energy, Idaho Operations Office (NE-ID).

\subsection{Idaho National Engineering and Environmental Laboratory Site Description}

The INEEL is approximately $890 \mathrm{mi}^{2}$ and is located on the eastern Snake River Plain (ESRP) in southeastern Idaho (Figure 1-1). It was established as a nuclear energy research and development testing station in the late 1940s and was designated a National Environmental Research Park in 1975. All land within the INEEL is protected as an outdoor laboratory where the effects of energy development and industrial activities on the environment and the complex ecological relationships of this cool desert ecosystem can be studied. The INEEL serves as a research area for scientists from several universities and state and federal agencies.

Subsurface geology at the INEEL consists of successive layers of basalt and sedimentary strata, overlaid at the surface by wind- and water-deposited sediments. The primary groundwater source of the region is the eastern Snake River Plain aquifer (ESRPA). Most of the INEEL is located in the Mud Lake-Lost River Basin (Pioneer Basin), which is an informally named, closed drainage basin. Surface water within the Pioneer Basin includes that from the Big Lost River, the Little Lost River, and Birch Creek, all of which drain mountain watersheds located to the north and northwest of the INEEL. All three water bodies may flow onto the INEEL during high flow years, but are otherwise intermittent. In addition, local rainfall and snowmelt contribute to surface water mainly during the spring. The portion of surface water that is not lost to evapotranspiration infiltrates into the subsurface. Both aquifer and surface waters are used for irrigating crops and other applications outside the INEEL.

The ESRPA is approximately $199 \mathrm{mi}$ long and 20 to $60 \mathrm{mi}$ wide and encompasses an area of about $9,650 \mathrm{mi}^{2}$. The depth to the ESPRA varies from $200 \mathrm{ft}$ in the northern part of the INEEL to over $900 \mathrm{ft}$ in the southern part. The ESRPA is the ESRP's source of groundwater. It is also the source of process water and drinking water both on and off the INEEL. The aquifer is recharged from infiltration of precipitation and irrigation seepage, runoff from the surrounding highlands, and groundwater underflows from the surrounding watersheds (DOE-ID 2002). Groundwater in the ESRPA flows generally to the 


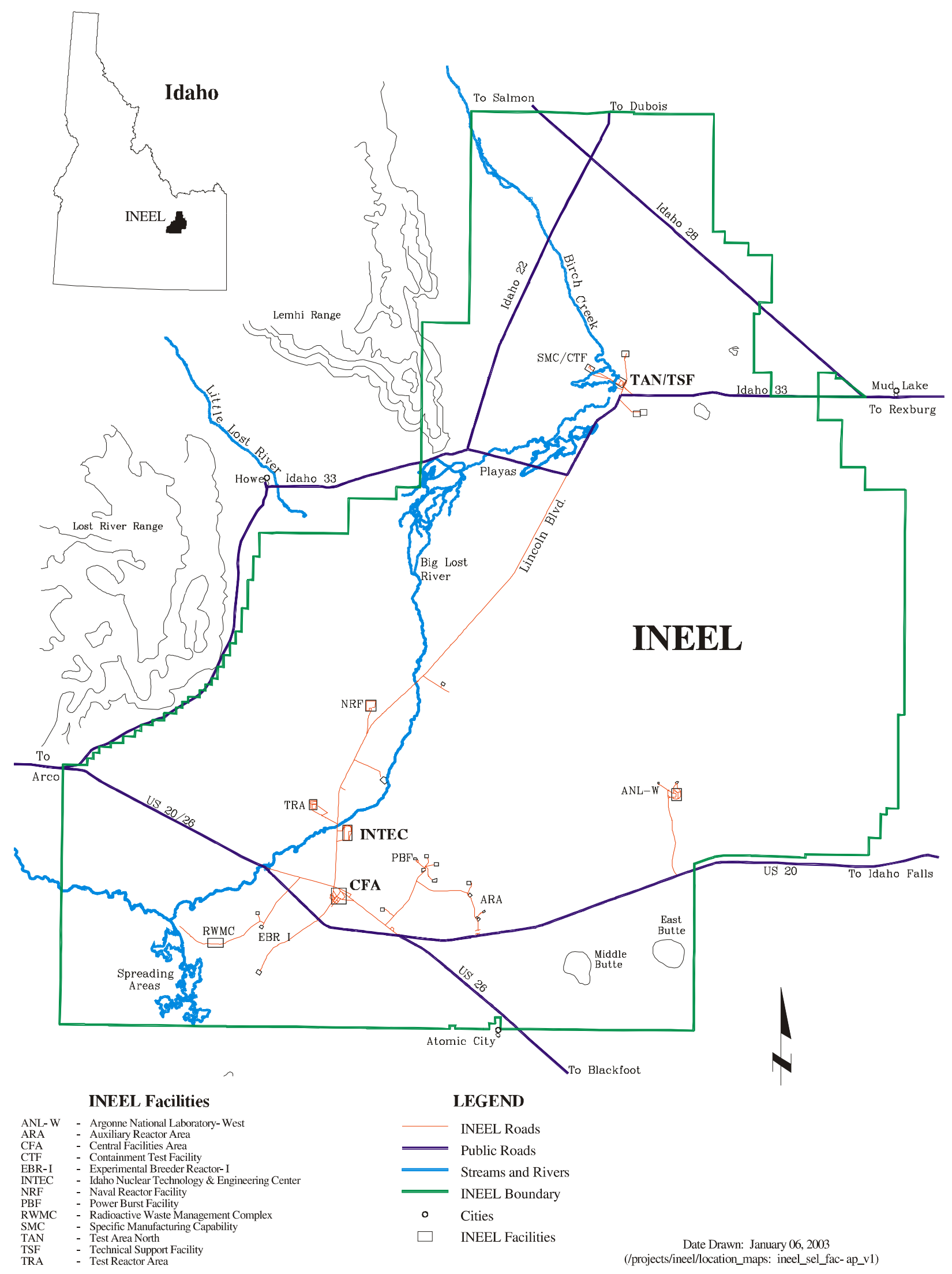

Figure 1-1. Idaho National Engineering and Environmental Laboratory. 
southwest, although locally the direction of flow is influenced by recharge from rivers, surface water, spreading areas, and heterogeneities in the aquifer. Tracer studies at the INEEL indicate that natural flow rates range from 5 to $20 \mathrm{ft} / \mathrm{d}$. Aquifer transmissivities range from $3 \times 10^{4}$ to $1.8 \times 10^{7} \mathrm{gal} / \mathrm{d} / \mathrm{ft}$; storage coefficients range from 0.01 to 0.06 (Robertson, Shoen, and Barrachlough 1974).

Meteorological and climatological data that apply to the INEEL region are collected and compiled from several meteorological stations operated by the National Oceanic and Atmospheric Administration field office in Idaho Falls, Idaho. Thirteen stations are located on the INEEL. Annual rainfall at the INEEL is light, and the region is classified as arid to semiarid (Clawson, Start, and Ricks 1989). The long-term average (from March 1950 through 2002) annual precipitation at the INEEL is 8.5 in. (at the CFA station). Monthly precipitation is usually highest in April, May, and June and lowest in July and October. The average daytime maximum temperature is $87^{\circ} \mathrm{F}$ (July), while the average daytime minimum temperature is $5^{\circ} \mathrm{F}$ (January) (Hukari 2003). The INEEL is in the belt of prevailing westerly winds, which are channeled within the plain to produce a west-southwesterly or southwesterly wind at most locations on the INEEL.

\subsection{Liquid Effluent Monitoring Program}

The INEEL Liquid Effluent Monitoring Program monitors effluent discharges at facilities operated by Bechtel BWXT Idaho, LLC (BBWI) at the INEEL. This program involves sampling, analysis, and data interpretation carried out under a quality assurance program. The INEEL Liquid Effluent Monitoring Program conducted effluent and influent monitoring as required by the Wastewater Land Application Permits (WLAPs) for the CFA STP, the INTEC STP, and the TAN/TSF STP during the 2003 permit year. INTEC Operations monitored effluent to the INTEC New Percolation Ponds.

Daily flow and monthly coliform readings were taken by CFA Wastewater Operations for the CFA STP, the INTEC STP, and the TAN/TSF STP during the 2003 permit year. Daily flow readings for the INTEC New Percolation Ponds were taken by INTEC Operations.

Effluent samples were collected each month according to INEEL sampling procedures and a randomly generated sampling schedule. Effluent samples were analyzed using methods described in 40 Code of Federal Regulations (CFR) 136, (40 CFR 136), with the following exceptions. For the INTEC New Percolation Ponds effluent samples, anions were analyzed using Environmental Protection Agency (EPA) Method 300.0 (EPA 1984) approved for drinking water. For the INTEC New Percolation Pond effluent samples, total phosphorus was analyzed using EPA Method 200.7 (MacConnel 2002). CFA Wastewater Operations and INTEC Operations personnel follow INEEL technical procedures to take the daily flow readings.

\subsection{Drinking Water Program}

For the INTEC New Percolation Ponds, Section G of the permit requires reporting the results of water quality testing performed at the Weapons Range B21-608 Building, which is monitored in accordance with the DEQ Drinking Water Program. These samples are collected by the INEEL Drinking Water Program and analyzed using approved drinking water methods.

\subsection{Groundwater Monitoring Program}

Groundwater was monitored in support of the WLAPs for the INTEC New Percolation Ponds, the INTEC STP, and the TAN/TSF STP following the sampling and analysis plan and INEEL procedures. All 
samples were collected in spring (April) and fall (October) at INTEC and TAN facilities. All samples were analyzed using EPA-approved methods.

\subsection{Soil Sample Collection}

The CFA STP WLAP requires the soil within the land application area to be sampled annually during each permit period. Five soil subsamples are collected from the land application area at two depths and then are composited in accordance with INEEL procedures and as specified in the permit. The samples are analyzed using Methods of Soil Analysis (Page 1982). 
1-6 


\section{CENTRAL FACILITIES AREA SEWAGE TREATMENT PLANT DATA SUMMARY AND ASSESSMENT}

\subsection{Site Description}

The Central Facilities Area (CFA) is about 50 mi west of Idaho Falls, Idaho, in Butte County Idaho, approximately $5 \mathrm{mi}$ from the INEEL southern boundary. The CFA provides functional space for crafts, offices, services, and laboratories for approximately 900 employees. CFA includes approximately 72 buildings and 62 other structures.

The CFA STP serves all major facilities at CFA. The STP is southeast of CFA (Figure 2-1), approximately $2,200 \mathrm{ft}$ downgradient of the nearest drinking water well. A public road passes approximately $0.75 \mathrm{mi}$ south of the STP, and the nearest inhabited building is approximately $2,000 \mathrm{ft}$ from the wastewater land application area.

\subsection{System Description and Operation}

The CFA STP was built in 1994 and put into service on February 6, 1995. Approximately 103,000 gallons per day (gpd) of water were processed from sanitary sewage drains throughout CFA during the 2003 permit year. Wastewater is derived from restrooms, showers, and the cafeteria, a significant portion of which is comprised of noncontact cooling water from air conditioners and heating systems. This large volume of cooling water dilutes the wastewater effluent. Other contributing discharge sources include those from bus and vehicle maintenance areas, analytical laboratories, and a medical dispensary.

The STP consists of:

- 1.7-acre partial-mix, aerated lagoon (Lagoon No. 1)

- 10.3-acre facultative lagoon (Lagoon No. 2)

- $\quad$ 0.5-acre polishing pond (Lagoon No. 3)

- $\quad$ Sprinkler pivot irrigation system, which applies wastewater on up to 73.5 acres of native desert rangeland.

Lagoon sizes presented for Lagoon Nos. 1 and No. 2 are based on the 8-foot design depth (INEEL 2003a). Under existing flow conditions, the winter storage capacity of the lagoons or ponds has been at least 8 months. Aeration can be used to mix, aerate, and agitate the wastewater within the cell of Lagoon No. 1.

A 400-gallon-per-minute pump applies wastewater from the lagoons to the land through a computerized center pivot system. The center pivot operates at low pressures $\left(30 \mathrm{lbs} / \mathrm{in}^{2}{ }^{2}\right)$ to minimize aerosols and spray drift. The permit limits wastewater application to 25 acre-in./acre/year from March 15 through November 15 and limits leaching losses to 3 in./year.

In 2003, wastewater application began June 16 and continued through September 25. The end gun on the pivot was used during 2003, resulting in an application area of approximately 73.5 acres. Aerial photographs of the STP area are presented in Appendix A as a visual record of changes in vegetation due 


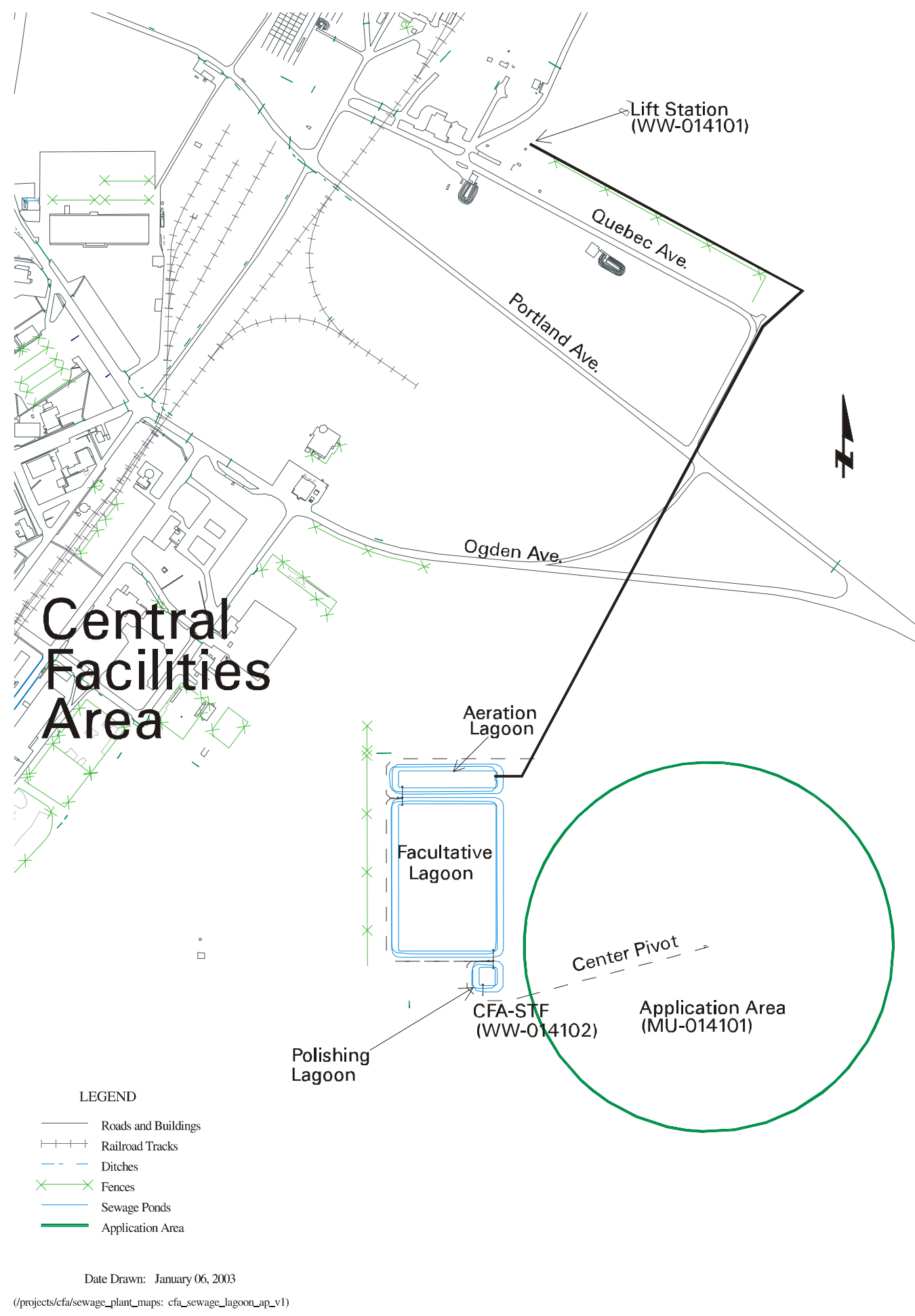

Figure 2-1. Central Facilities Area Sewage Treatment Plant. 
to the operation of the pivot. A photograph is included for each year since the permit was issued, except for the 2001 permit year. Photographs were scheduled to be taken in late fall 2001. However, due to the increased security and closed airspace over the INEEL after September 11, 2001, aerial photographs could not be taken prior to the end of the 2001 permit year.

The original WLAP issued for the CFA STP expired August 7, 1999 (Green 1994). A renewal application was submitted February 9, 1999 (Bennett 1999). A letter authorizing the continued operation of the CFA STP under the original WLAP was issued September 18, 2000 (Johnston 2000). In compliance with Section 1 of the WLAP, which states that "wastewater shall be managed substantially in accordance with the plan of operation," the CFA STP Operations and Maintenance (O\&M) Manual was modified to reflect current operating methodologies. The manual was submitted to DEQ on November 29, 2001 (Rugg 2001). DEQ provided comments (Rackow 2002b) on the modified O\&M Manual, the INEEL submitted a response to DEQ on April 9, 2002 (Rugg 2002), and the INEEL provided additional supporting information on January 20, 2003 (Guymon 2003a). The O\&M Manual, dated November 2001, was approved by the DEQ on April 2, 2003 (Rackow 2003a).

\subsection{Status of Special Compliance Conditions}

No special compliance conditions were in effect during the 2003 permit year.

\subsection{Influent and Effluent Monitoring Results}

The permit year is from November 16, 2002, through November 15, 2003. However, to provide a more complete data set and for water balance calculations, data are reported from December 1, 2002, through November 30, 2003.

Influent samples were collected monthly from the lift station at CFA (prior to Lagoon No. 1) during the permit year. Effluent samples were collected from the pump pit (prior to the pivot) starting in June and continued through the months of pivot operation. All samples collected were 24-hour composite samples, except the $\mathrm{pH}$ and coliform samples, which are grab samples. CFA Wastewater Operations personnel collect coliform samples. Tables 2-1 and 2-2 summarize the influent and effluent results.

Yearly average concentrations for all parameters measured in the influent to the lagoons were at or below concentrations typically classified as "weak" municipal wastewater (biochemical oxygen demand $[\mathrm{BOD}]<110$, chemical oxygen demand $[\mathrm{COD}]<250$, total suspended solids $[\mathrm{TSS}]<100$, and total nitrogen $[\mathrm{N}]<20 \mathrm{mg} / \mathrm{L}$ ) (Metcalf and Eddy 1979). The average TSS and BOD concentrations in the influent were greater than those for the 2002 permit year, while the yearly average concentrations for the remainder of the permit parameters were less than those for the 2002 permit year. However, all permit parameters were within historical ranges.

The yearly average concentrations for TSS and $\mathrm{pH}$ measured in the effluent discharged to the pivot were lower than those of the 2002 permit year, while the remaining parameters were higher than those for the 2002 permit year. However, all parameters were within the historical ranges.

Removal efficiencies (REs) were calculated to estimate treatment in the lagoons (Table 2-3). Average REs were lower than the previous year for total nitrogen, BOD, and COD, but equal to the previous year for TSS. Only BOD and TSS achieved the projected efficiency (i.e., total nitrogen, BOD, and TSS of $80 \%$ and COD of 70\%). During the 2003 permit year, the average REs indicate that treatment in the lagoons was sufficient to produce a good quality effluent for land application. 
Table 2-1. Central Facilities Area Sewage Treatment Plant influent water quality data from lift station (WW-014101).

\begin{tabular}{|c|c|c|c|c|c|c|c|}
\hline Sample Month & $\begin{array}{c}\text { Sample } \\
\text { Date }\end{array}$ & $\begin{array}{c}\mathrm{TKN} \\
(\mathrm{mg} / \mathrm{L})\end{array}$ & $\begin{array}{l}\mathrm{NNN}^{\mathrm{a}} \\
(\mathrm{mg} / \mathrm{L})\end{array}$ & $\begin{array}{c}\text { BOD } \\
(\mathrm{mg} / \mathrm{L})\end{array}$ & $\begin{array}{c}\text { COD } \\
(\mathrm{mg} / \mathrm{L})\end{array}$ & $\begin{array}{c}\mathrm{TSS} \\
(\mathrm{mg} / \mathrm{L}) \\
\end{array}$ & $\mathrm{pH}$ \\
\hline December & $12 / 10 / 2002$ & 18.20 & 0.420 & 58.4 & 119.0 & 76.0 & 7.92 \\
\hline January & $01 / 22 / 2003$ & 19.50 & 0.499 & 49.7 & 196.0 & 28.3 & 7.65 \\
\hline February & $02 / 04 / 2003$ & 1.73 & 0.336 & 51.2 & 147.0 & 95.7 & 7.92 \\
\hline March & $03 / 05 / 2003$ & 24.90 & 0.774 & 54.6 & 93.3 & 55.9 & 8.15 \\
\hline April & $04 / 29 / 2003$ & $1.60^{\mathrm{b}}$ & $0.481^{\mathrm{b}}$ & $29.85^{\mathrm{b}}$ & $102.5^{\mathrm{b}}$ & $36.45^{\mathrm{b}}$ & 8.21 \\
\hline May & $05 / 28 / 2003$ & 12.80 & 1.220 & 56.8 & 77.4 & 40.5 & 7.70 \\
\hline June & $06 / 19 / 2003$ & 12.30 & 0.642 & 53.5 & 56.5 & 31.1 & 7.62 \\
\hline July & $07 / 30 / 2003$ & 10.30 & 0.979 & 23.0 & 73.5 & 18.9 & 7.66 \\
\hline August & $08 / 20 / 2003$ & 11.60 & 0.409 & 37.4 & 41.8 & 33.8 & 7.95 \\
\hline September & $09 / 24 / 2003$ & 5.13 & 0.765 & 44.1 & 54.6 & 48.4 & 7.76 \\
\hline October & $10 / 14 / 2003$ & 17.70 & 0.354 & 47.8 & 79.2 & 68.5 & 7.75 \\
\hline November & $11 / 04 / 2003$ & 14.60 & 0.479 & 59.1 & 120.0 & 324.0 & 7.82 \\
\hline Yearly Average $\mathrm{c}^{\mathrm{c}}$ & & 12.53 & 0.613 & 47.1 & 96.7 & 71.5 & 7.84 \\
\hline $\begin{array}{ll}\text { a. } & \text { NNN }- \text { Nitrate }+ \text { ni } \\
\text { b. } & \text { The result shown is } \\
\text { c. } & \text { Yearly average is d } \\
\end{array}$ & $\begin{array}{l}\text { as nitrogen.. } \\
\text { average of the dur } \\
\text { nined from the av }\end{array}$ & $\begin{array}{l}\text { samples tak } \\
\text { of the month }\end{array}$ & $\begin{array}{l}\text { he month. } \\
\text { es. }\end{array}$ & & & & \\
\hline
\end{tabular}

Table 2-2. Central Facilities Area Sewage Treatment Plant effluent water quality data prior to pivot (WW-014102).

\begin{tabular}{|c|c|c|c|c|c|c|c|c|c|c|}
\hline $\begin{array}{l}\text { Sample } \\
\text { Month }\end{array}$ & $\begin{array}{c}\text { Sample } \\
\text { Date }\end{array}$ & $\begin{array}{c}\text { TKN } \\
(\mathrm{mg} / \mathrm{L})\end{array}$ & $\begin{array}{l}\mathrm{NNN}^{\mathrm{a}} \\
(\mathrm{mg} / \mathrm{L})\end{array}$ & $\begin{array}{c}\text { BOD } \\
(\mathrm{mg} / \mathrm{L})\end{array}$ & $\begin{array}{c}\text { COD } \\
(\mathrm{mg} / \mathrm{L})\end{array}$ & $\begin{array}{c}\mathrm{TSS} \\
(\mathrm{mg} / \mathrm{L})\end{array}$ & $\mathrm{pH}$ & $\begin{array}{c}\text { Total } \\
\text { Phosphorus } \\
(\mathrm{mg} / \mathrm{L})\end{array}$ & $\begin{array}{c}\text { Fecal } \\
\text { Coliform } \\
(\mathrm{col} / 100 \mathrm{~mL})\end{array}$ & $\begin{array}{c}\text { Total } \\
\text { Coliform }^{\mathrm{b}} \\
(\mathrm{col} / 100 \mathrm{~mL})\end{array}$ \\
\hline June & $6 / 19 / 2003$ & 1.81 & 0.071 & 4.35 & 35.3 & 6.5 & 9.89 & 0.316 & 1 & 8 \\
\hline July & $7 / 30 / 2003$ & 4.25 & 0.034 & 2.14 & 34.5 & $4.0 \mathrm{U}^{\mathrm{c}}$ & $9.13^{\mathrm{d}}$ & 0.408 & 1 & 6 \\
\hline August & $8 / 20 / 2003$ & 6.70 & 0.012 & 7.38 & 40.1 & $4.0 \mathrm{U}$ & 9.48 & 0.235 & 29 & 80 \\
\hline September & $9 / 24 / 2003$ & 2.90 & 0.012 & 3.15 & 41.6 & $4.0 \mathrm{U}$ & 9.56 & 0.213 & 1 & 1 \\
\hline \multicolumn{2}{|c|}{ Yearly Average $^{\mathrm{e}}$} & 3.92 & 0.032 & 4.26 & 37.9 & 3.1 & 9.52 & 0.293 & 8 & 24 \\
\hline \multicolumn{11}{|c|}{ a. $\quad \mathrm{NNN}-$ Nitrate + nitrite as nitrogen. } \\
\hline \multicolumn{11}{|c|}{ b. Coliform samples were collected independent of the composite samples on $6 / 18 / 2003,7 / 31 / 2003,8 / 20 / 2003$, and $9 / 25 / 2003$. } \\
\hline \multicolumn{11}{|c|}{ c. $\quad \mathrm{U}$ flag indicates that the result was reported as below the detection limit. } \\
\hline \multicolumn{11}{|c|}{ d. The result shown represents the average of multiple samples taken for the month. } \\
\hline \multicolumn{11}{|c|}{$\begin{array}{l}\text { e. Yearly average is determined from the average of the monthly values. Half the reported detection limit was used in the yearly average calculation for those results } \\
\text { reported as below the detection limit. }\end{array}$} \\
\hline
\end{tabular}


Table 2-3. 2003 removal efficiency ${ }^{\mathrm{a}}$ percentages for Central Facilities Area Sewage Treatment Plant permit monitoring parameters.

\begin{tabular}{lcccc}
\hline \multicolumn{1}{c}{ Sample Month } & $\begin{array}{c}\text { Total Nitrogen } \\
(\%)\end{array}$ & $\begin{array}{c}\text { BOD } \\
(\%)\end{array}$ & $\begin{array}{c}\text { COD } \\
(\%)\end{array}$ & $\begin{array}{c}\text { TSS } \\
(\%)\end{array}$ \\
\hline June 2003 & 85 & 92 & 38 & 79 \\
July 2003 & 62 & 91 & 53 & $89^{\mathrm{c}}$ \\
August 2003 & 44 & 80 & 4 & $94^{\mathrm{c}}$ \\
September 2003 & 51 & 93 & 24 & $96^{\mathrm{c}}$ \\
Yearly Average RE & 61 & 89 & 30 & 90
\end{tabular}

a. Removal efficiency $(\mathrm{RE})=[($ average monthly influent concentration - average monthly effluent concentration $) \div$ average monthly influent concentration] $\times 100$.

b. Total nitrogen is calculated as the sum of the TKN and NNN results.

c. For TSS, half the detection limit was used in the RE calculation for the effluent concentration because the effluent result was reported as below the detection limit.

\subsubsection{Flow Volumes and Loading Rates}

Daily influent flow readings were recorded at the flow meter prior to the first lagoon during the permit year. Daily effluent flow readings were recorded at the pivot control panel when the pivot was operating. All flow readings were recorded in gallons per day (gpd). Table 2-4 summarizes monthly and annual flow data, and Appendix A presents daily flow readings and copies of the required electronic WLAP data files (DEQ 2002a).

Daily influent flows averaged less than 104,000 gpd, which was much less than the design flow of $250,000 \mathrm{gpd}$. Average daily flows continued to be greatest during the summer. Total influent flow volume was approximately 38 million gallons (MG) for the permit year. Discharge to the pivot averaged less than $158,000 \mathrm{gpd}$. The end gun was used during the entire 2003 application period (June 16, 2003, through September 25, 2003). Application rates ranged from 0.07 to 0.08 acre-in./day.

Table 2-5 presents hydraulic and nutrient loading rates. The total volume of applied wastewater for 2003 was approximately 5.98 MG, which is significantly less than the design hydraulic loading of 40.5 MG. Hydraulic loading peaked in September. Nitrogen loading rates were significantly lower $(2.7 \mathrm{lb} / \mathrm{acre} / \mathrm{yr})$ than the projected maximum loading rate of $32 \mathrm{lb} / \mathrm{acre} / \mathrm{year}$. As a general rule, nitrogen loading should not exceed the amount necessary for crop utilization plus $50 \%$. However, wastewater is applied to native rangeland without nitrogen removal via crop harvest. To estimate nitrogen buildup in the soil under this condition, a nitrogen balance was prepared by Cascade Earth Sciences, Ltd. (CES), which estimated it would take 20 to 30 years to reach normal nitrogen agricultural levels in the soil (based on a loading rate of $32 \mathrm{lb} /$ acre/year) (CES 1993). The extremely low 2003 nitrogen loading rate of $2.7 \mathrm{lb} /$ acre/year had a negligible effect on nitrogen accumulation.

The 2003 annual total COD loading rate at CFA STP (26 lb/acre/year) was less than the previous year and was substantially less than the state guidelines of $50 \mathrm{lb} /$ acre/day (which is equivalent to $18,250 \mathrm{lb} / \mathrm{acre} / \mathrm{year})$. 
Table 2-4. Central Facilities Area Sewage Treatment Plant flow summaries.

\begin{tabular}{|c|c|c|c|c|c|c|c|c|}
\hline \multirow[b]{2}{*}{ Sample Month } & \multicolumn{4}{|c|}{ Influent to Pond (WW-014101) } & \multicolumn{4}{|c|}{ Effluent to Pivot (WW-014102) } \\
\hline & $\begin{array}{c}\text { Average } \\
\left(\operatorname{gpd}^{\mathrm{a}}\right)\end{array}$ & $\begin{array}{l}\text { Minimum } \\
\text { (gpd) }\end{array}$ & $\begin{array}{l}\text { Maximum } \\
\text { (gpd) }\end{array}$ & $\begin{array}{l}\text { Total } \\
(\mathrm{MG})^{\mathrm{b}}\end{array}$ & $\begin{array}{l}\text { Average } \\
\text { (gpd) }\end{array}$ & $\begin{array}{l}\text { Minimum } \\
\text { (gpd) }\end{array}$ & $\begin{array}{l}\text { Maximum } \\
\text { (gpd) }\end{array}$ & $\begin{array}{c}\text { Total to } \\
\text { Field } 1 \\
(\mathrm{MU}-014101) \\
(\mathrm{MG})^{\mathrm{b}}\end{array}$ \\
\hline December 2002 & 76,770 & 49,298 & 104,673 & 2.38 & $\mathrm{NF}^{\mathrm{c}}$ & NF & NF & $\mathrm{NF}$ \\
\hline January 2003 & 81,294 & 58,886 & 106,169 & 2.52 & $\mathrm{NF}$ & $\mathrm{NF}$ & $\mathrm{NF}$ & $\mathrm{NF}$ \\
\hline February 2003 & 79,717 & 58,806 & 103,273 & 2.23 & NF & $\mathrm{NF}$ & NF & $\mathrm{NF}$ \\
\hline March 2003 & 82,097 & 50,963 & 114,566 & 2.55 & $\mathrm{NF}$ & $\mathrm{NF}$ & $\mathrm{NF}$ & NF \\
\hline April 2003 & 85,701 & 59,748 & 108,291 & 2.57 & NF & $\mathrm{NF}$ & NF & $\mathrm{NF}$ \\
\hline May 2003 & 96,605 & 62,695 & 153,865 & 2.99 & NF & $\mathrm{NF}$ & NF & $\mathrm{NF}$ \\
\hline June 2003 & 119,263 & 74,027 & 178,156 & 3.58 & 155,863 & 139,600 & 163,200 & 1.25 \\
\hline July 2003 & 135,727 & 20,637 & 188,795 & 4.21 & 157,967 & 150,700 & 165,400 & 1.42 \\
\hline August 2003 & 152,026 & 95,065 & 188,256 & 4.71 & 157,670 & 148,900 & 159,300 & 1.58 \\
\hline September 2003 & 130,676 & 96,830 & 168,057 & 3.92 & 157,336 & 150,300 & 162,500 & 1.73 \\
\hline October 2003 & 112,646 & 69,239 & 174,677 & 3.49 & $\mathrm{NF}$ & $\mathrm{NF}$ & $\mathrm{NF}$ & $\mathrm{NF}$ \\
\hline November 2003 & 86,377 & 66,633 & 114,132 & 2.59 & $\mathrm{NF}$ & $\mathrm{NF}$ & $\mathrm{NF}$ & $\mathrm{NF}$ \\
\hline Yearly Summary & 103,410 & 20,637 & 188,795 & 37.74 & 157,263 & 139,600 & 165,400 & 5.98 \\
\hline $\begin{array}{ll}\text { a. } & \text { gpd-Gallons } \\
\text { b. } & \text { Monthly and a } \\
\text { c. } & \text { NF-No flow. }\end{array}$ & $\begin{array}{l}\text { er day. } \\
\text { nual totals }\end{array}$ & shown in & on gallons & & & & & \\
\hline
\end{tabular}

Table 2-5. 2003 hydraulic and nutrient loading rates. ${ }^{a}$

\begin{tabular}{|c|c|c|c|c|c|}
\hline \multirow[b]{2}{*}{ Sample Month } & \multicolumn{2}{|c|}{ Applied Wastewater } & \multirow[b]{2}{*}{$\begin{array}{c}\text { Total } \\
\text { Nitrogen }^{\mathrm{c}} \\
\text { (lb/acre) }\end{array}$} & \multirow[b]{2}{*}{$\begin{array}{c}\mathrm{COD} \\
(\mathrm{lb} / \mathrm{acre})\end{array}$} & \multirow[b]{2}{*}{$\begin{array}{c}\text { Total } \\
\text { Phosphorus } \\
\text { (lb/acre) }\end{array}$} \\
\hline & $\begin{array}{l}\text { Total } \\
(\mathrm{MG})^{\mathrm{b}}\end{array}$ & $\begin{array}{c}\text { Per Acre } \\
\text { (MG) }\end{array}$ & & & \\
\hline June & 1.25 & 0.017 & 0.266 & 4.997 & 0.045 \\
\hline July & 1.42 & 0.019 & 0.678 & 5.458 & 0.065 \\
\hline August & 1.58 & 0.021 & 1.174 & 7.012 & 0.041 \\
\hline September & 1.73 & 0.024 & 0.582 & 8.314 & 0.043 \\
\hline Yearly Total & 5.98 & 0.081 & 2.700 & 25.781 & 0.194 \\
\hline \multicolumn{6}{|c|}{$\begin{array}{l}\text { a. Loading rates calculated for wastewater application on up to } 73.5 \text { acres (hydraulic management unit MU-014101). } \\
\text { b. MG-Million gallons. } \\
\text { c. Total nitrogen is determined from the sum of the TKN and NNN results. }\end{array}$} \\
\hline
\end{tabular}


The annual total phosphorus loading rate $(0.194 \mathrm{lb} / \mathrm{acre} / \mathrm{year})$ was well below the projected maximum loading rate of $4.5 \mathrm{lb} /$ acre/year. The small amount of phosphorus applied was probably removed by sorption reactions in the soil and utilized by vegetation, rather than lost to groundwater.

\subsubsection{Soil Water Balance}

A monthly water balance software package was prepared by Cascade Earth Sciences, Ltd. to determine leaching losses (Maloney 1993; Bruner 1994). This water balance software calculates leaching losses based on:

- $\quad$ Soil available water capacity

- Precipitation

- Wastewater application

- Evapotranspiration.

This calculation:

- $\quad$ Assumes full soil profile water storage on April 1

- $\quad$ Applies an adjustment factor of $84 \%$ to the measured precipitation values to account for interception by vegetation onsite

- Applies an irrigation efficiency factor to the measured wastewater flows to account for evaporation resulting from spraying. (Irrigation efficiencies of $70 \%$ were used for the center pivot for June, July, and August, and 80\% for September.)

Potential and actual evapotranspiration values are estimated based on average monthly temperatures and the volume of water stored in the soil, respectively. The National Oceanic and Atmospheric Administration measures monthly precipitation and temperature at the CFA Weather Station.

A projected water balance was submitted with the original WLAP application to the DEQ. Table 2-6 shows the water balance for the 2003 permit year. A total of 2.99 acre-in./acre of wastewater was applied over approximately 73.5 acres during the 2003 permit year, which was 4.26 in. less than that applied in 2002. This total, when adjusted for irrigation efficiency and added to the total adjusted precipitation for the permit year, yields 5.62 acre-in./acre, which is well below the permit limit of 25 acre-in./acre/year. The relatively low volume of wastewater, coupled with below average annual precipitation (lower by $4.4 \mathrm{in}$.) and above average monthly temperatures for all months of the permit year (with the exception of November 2003), resulted in a leaching loss of only $0.10 \mathrm{in}$.

The leaching loss of 0.10 in. occurred in April 2003 when the model assumes full soil profile water storage. While there was no wastewater applied during the month of April 2003, the calculated leaching loss can be attributed to the model's assumed full soil profile and the addition of 1.56 inches of precipitation during the month (more than double the monthly average). The assumption of a full soil profile in April and the calculated leaching loss of 0.10 in. are considered very conservative based on the below average annual precipitation volumes for the previous several years. 
Table 2-6. Central Facilities Area Sewage Treatment Plant monthly water balance for 5.98 MG wastewater applied to the irrigation area. ${ }^{\mathrm{a}}$

\begin{tabular}{|c|c|c|c|c|c|c|c|c|c|}
\hline \multirow[b]{2}{*}{ Month } & \multicolumn{4}{|c|}{$\begin{array}{l}\text { Water Applied } \\
\text { (in.) }\end{array}$} & \multirow[b]{2}{*}{$\begin{array}{l}\text { Total } \\
\text { (in.) }\end{array}$} & \multicolumn{2}{|c|}{$\begin{array}{l}\text { Evapotranspiration }{ }^{\mathrm{b}} \\
\text { (in.) }\end{array}$} & \multirow{2}{*}{$\begin{array}{l}\text { Stored } \\
\text { in Soil } \\
\text { (in.) } \\
\end{array}$} & \multirow{2}{*}{$\begin{array}{c}\text { Leaching } \\
\text { Loss }^{\mathrm{e}} \\
\text { (in.) }\end{array}$} \\
\hline & $\mathrm{PPT}^{\mathrm{c}}$ & $\begin{array}{l}\mathrm{ADJ} \\
\mathrm{PPT}^{\mathrm{c}}\end{array}$ & Waste $^{\mathrm{d}}$ & $\begin{array}{c}\text { ADJ } \\
\text { Waste }^{d}\end{array}$ & & PET & $\mathrm{ACT}$ & & \\
\hline December 2002 & 0.25 & 0.21 & 0 & 0 & 0.21 & 0.25 & 0.25 & 0 & 0 \\
\hline January 2003 & 0.16 & 0.13 & 0 & 0 & 0.13 & 0.24 & 0.24 & 0 & 0 \\
\hline February 2003 & 0.42 & 0.35 & 0 & 0 & 0.35 & 0.25 & 0.25 & 0.11 & 0 \\
\hline March 2003 & 0.26 & 0.22 & 0 & 0 & 0.22 & 0.69 & 0.67 & 0 & 0 \\
\hline April 2003 & 1.56 & 1.31 & 0 & 0 & 1.31 & 1.22 & 1.22 & 8.22 & 0.10 \\
\hline May 2003 & 0.46 & 0.39 & 0 & 0 & 0.39 & 2.74 & 2.32 & 6.29 & 0 \\
\hline June 2003 & 0.03 & 0.03 & 0.62 & 0.43 & 0.46 & 4.14 & 3.08 & 3.67 & 0 \\
\hline July 2003 & 0.00 & 0.00 & 0.71 & 0.50 & 0.50 & 6.20 & 3.43 & 0.74 & 0 \\
\hline August 2003 & 0.18 & 0.15 & 0.79 & 0.55 & 0.70 & 5.28 & 3.52 & 0 & 0 \\
\hline September 2003 & 0.44 & 0.37 & 0.87 & 0.70 & 1.07 & 2.52 & 2.29 & 0 & 0 \\
\hline October 2003 & 0.08 & 0.07 & 0 & 0 & 0.07 & 1.32 & 1.21 & 0 & 0 \\
\hline November 2003 & 0.26 & 0.22 & 0 & 0 & 0.22 & 0.30 & 0.30 & 0 & 0 \\
\hline \multirow[t]{2}{*}{ Total: } & 4.10 & 3.44 & 2.99 & 2.18 & 5.62 & 25.14 & 18.75 & 0 & 0.10 \\
\hline & & & \multicolumn{5}{|c|}{ Soil Available Water Capacity ${ }^{\mathrm{f}}$ : } & \multicolumn{2}{|l|}{8.22} \\
\hline \multicolumn{2}{|c|}{ b. PET—potential evapotranspiration; ACT—actual evapotranspiration. } & & & & & & & & \\
\hline \multicolumn{10}{|c|}{$\begin{array}{l}\text { c. PPT— precipitation. ADJ PPT—adjusted precipitation. An efficiency factor was applied to the raw monthly data to account for interception by } \\
\text { native vegetation (Linsley, Kohler, and Paulhus 1982). }\end{array}$} \\
\hline \multicolumn{10}{|c|}{$\begin{array}{l}\text { d. Waste-applied wastewater. ADJ Waste_-applied wastewater adjusted for irrigation losses. A monthly efficiency factor was applied to correct } \\
\text { for irrigation losses due to evaporation (Department of Agriculture 1986). }\end{array}$} \\
\hline \multicolumn{10}{|c|}{ e. Leaching losses of water moving below the rooting zone (assumed to be a depth of $52 \mathrm{in}$.). } \\
\hline f. Soil available water & ity was & xin & field measu & ments and te & cural anal & & & & \\
\hline
\end{tabular}

\subsection{Evaluation of Groundwater Data}

Groundwater monitoring is not required by the current permit based on the following:

- $\quad$ Quantity and quality of water discharged

- $\quad$ Local geology and hydrology

- $\quad$ Distance to nearest downgradient drinking water well (Experimental Breeder Reactor-I production well approximately $3.5 \mathrm{mi}$ southwest).

However, as discussed in previous WLAP reports, groundwater sampling results of several wells downgradient of the STP identified nitrate + nitrite near or above the applicable state groundwater quality concentration limits of $10 \mathrm{mg} / \mathrm{L}$. These limits are the primary constituent standards (PCSs) specified in IDAPA 58.01.11, "Ground Water Quality Rule." 
Three wells, which were constructed as part of the CFA regional groundwater monitoring network in 1995 (CFA-MON-A-001, -002, and -003), are located generally downgradient of the new CFA STP (Figure 2-2). Since 1995, nitrate + nitrite concentrations in well CFA-MON-A-001 were well below the primary constituent standard of $10 \mathrm{mg} / \mathrm{L}$ (Figure 2-3). Over the same period, the nitrate + nitrite concentrations in wells CFA-MON-A-002 and -003 (Figures 2-4 and 2-5, respectively) were above or near the primary constituent standard.

Previous evaluations have indicated that the new CFA STP is not a likely source of nitrate + nitrite based on effluent concentrations and the vadose zone and groundwater travel time between the new CFA STP and the wells (INEEL 2000). Total nitrogen concentrations in the CFA STP effluent are consistently too low to provide a steady source of nitrate + nitrite from lagoon seepage at the concentrations detected in the wells. In addition, based on water balance calculations showing minimal leaching losses from land application, it is unlikely that the effluent is migrating from the land application area to the aquifer.

Several evaluations have been conducted to determine the potential source of the nitrate + nitrite. Waste Area Group (WAG) 4, which is responsible for implementing characterization and cleanup activities at CFA under the INEEL's Federal Facilities Agreement and Consent Order (FFA/CO) as part of the Comprehensive Environmental Response, Compensation, and Liability Act (CERCLA) Program, continues to monitor and evaluate the nitrate concentrations in these three wells. Based on current information, the two most likely sources of nitrate found in these wells are the CFA-04 dry pond and the CFA-08 drainfield (INEEL 2003b). Because the source of the nitrate + nitrite concentrations are still not believed to be from the new CFA STP, the wells will continue to be monitored by the INEEL FFA/CO Program.

\subsection{Soil Monitoring}

Cascade Earth Sciences, Ltd. characterized soils at the CFA STP prior to construction. Soils in the upper 6 in. are predominantly silty clay loam and from 6 to 52 in. are predominantly silt loam. Soils at CFA were determined to be suitable for slow-rate wastewater application (EG\&G 1993).

Soils have since been sampled from the land application area (locations 1 through 5 shown in Figure 2-6) following each application season. Subsamples were taken from 0-12 in. and 12-24 in. at each location and composited, yielding two composite samples, one from each depth. These results are presented in Table 2-7. In addition, preapplication data collected by Cascade Earth Sciences, Ltd. are presented for comparison purposes.

During 2003, pH levels and percent organic matter at both the $0-12$ in. and the 12-24 in. intervals were similar to preapplication levels. The soil salinity levels were within acceptable ranges based on electrical conductivity results. Soil salinity levels between $0-2 \mathrm{mmhos} / \mathrm{cm}$ are generally accepted to have negligible effects on plant growth. During 2003, while the electrical conductivity in the 0-12 in. interval represented the historic high, both intervals remained within the $0-2 \mathrm{mmhos} / \mathrm{cm}$ range.

Soils with sodium adsorption ratios (SARs) below 15 and electrical conductivity levels below $2 \mathrm{mmhos} / \mathrm{cm}$ are generally classified as not having sodium or salinity problems (Bohn, McNeal, and O'Connor 1985). During 2003, SARs were elevated at both depths relative to preapplication SARs. However, they remain well below 15. The SAR is an indicator of the exchangeable sodium levels in the soil. Soils with high exchangeable sodium levels tend to crust badly or disperse, which greatly decreases soil hydraulic conductivity. 


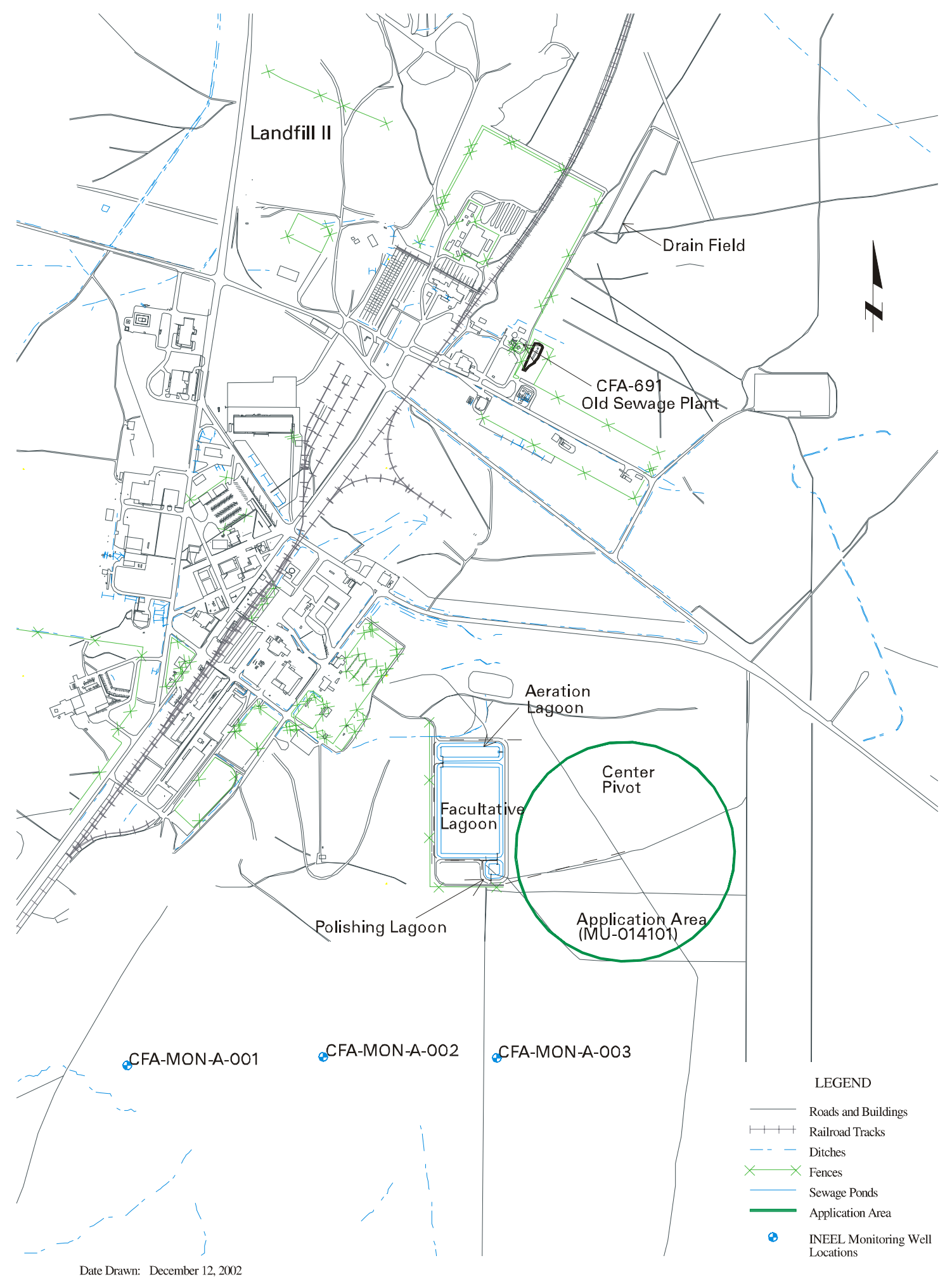

(projects/cfa/sewage_plant_maps: cfa_sewage_lagoon_wells-ap_v5)

Figure 2-2. Locations of monitoring wells in the vicinity of the Central Facilities Area Sewage Treatment Plant. 


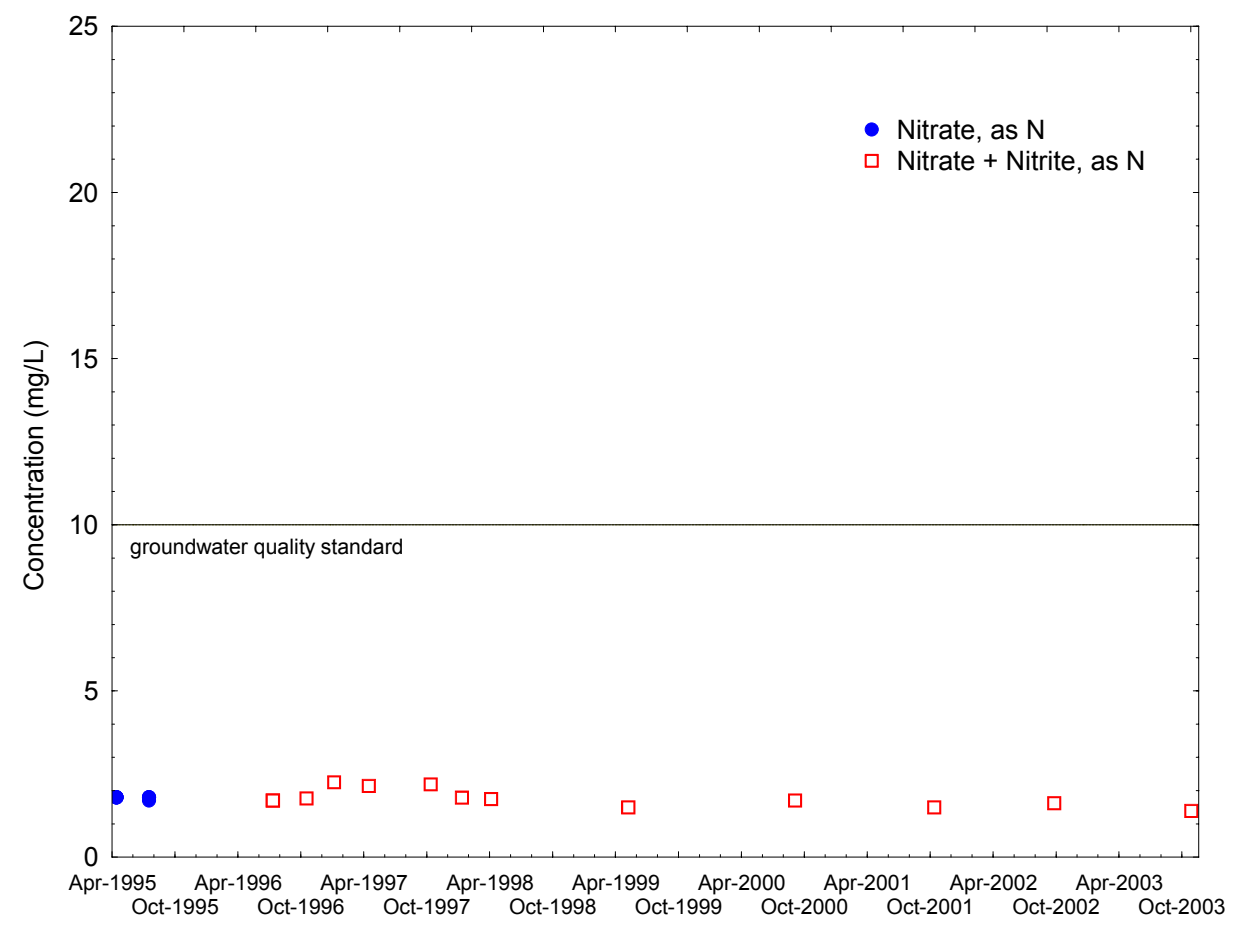

Figure 2-3. Nitrate + nitrite (as N) at CFA-MON-A-001.

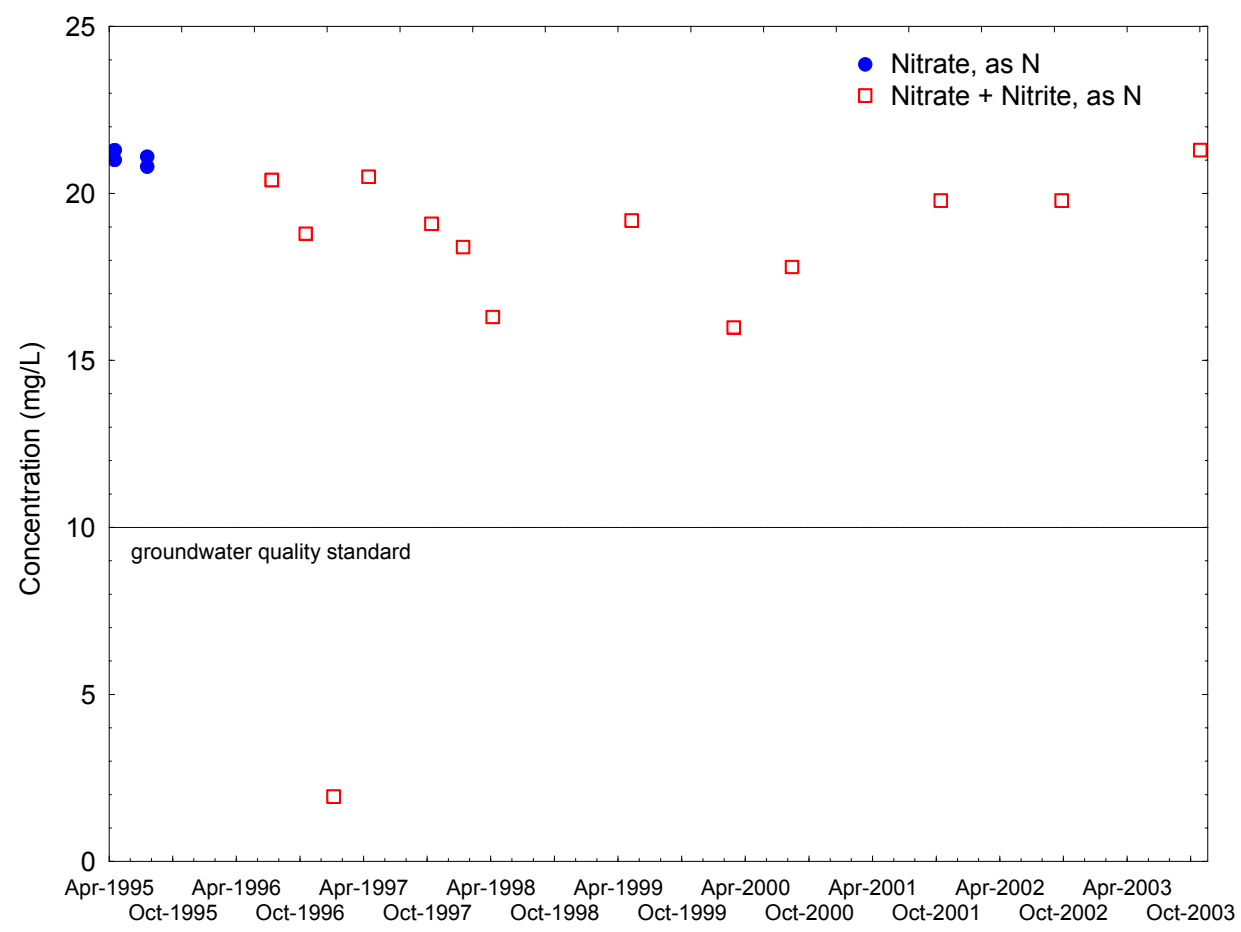

Figure 2-4. Nitrate + nitrite (as N) at CFA-MON-A-002. 


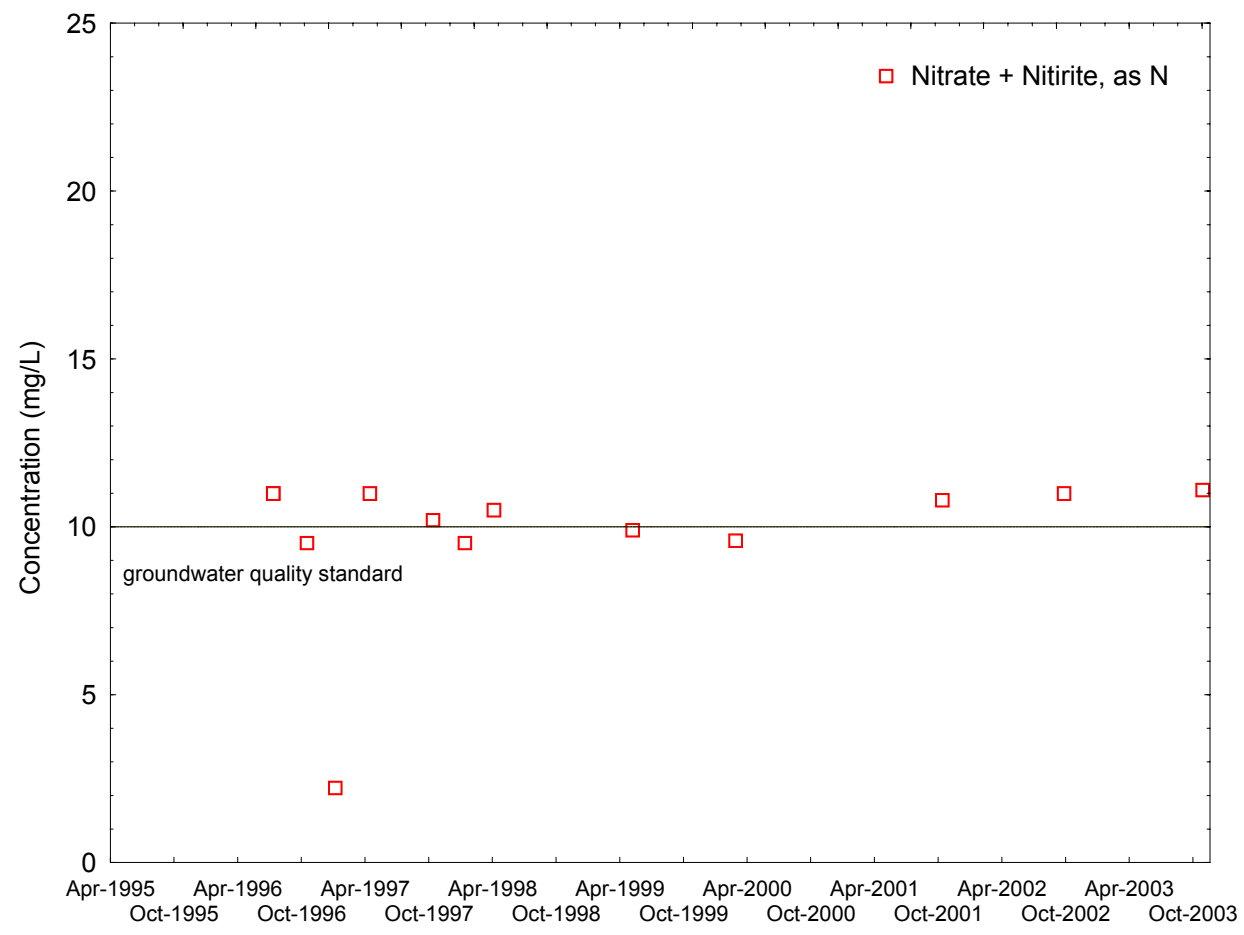

Figure 2-5. Nitrate + nitrite (as N) at CFA-MON-A-003.

Nitrogen data suggest negligible nitrogen accumulation from wastewater application. Ammonium $\left(\mathrm{NH}_{4}-\mathrm{N}\right)$ and nitrate as nitrogen $\left(\mathrm{NO}_{3}-\mathrm{N}\right)$ concentrations continue to be well below preapplication concentrations. The low soil-available nitrogen $\left(\mathrm{NH}_{4}-\mathrm{N}\right.$ and $\left.\mathrm{NO}_{3}-\mathrm{N}\right)$ concentrations suggest that the native sagebrush and grass vegetation utilize all of the plant-available nitrogen and that the total nitrogen application is low. Increased nutrients and water from wastewater application may be stimulating plant growth, which in turn rapidly utilizes plant-available nitrogen. The ammonium and nitrate as nitrogen concentrations are comparable to those of nonfertilized, background agricultural soils.

The original permit required total phosphorus analysis of soils; however, because the total phosphorous content includes the digestion of phosphate minerals, the results of total phosphorous analyses are not indicative of plant-available phosphorous or water-soluble phosphorous that could leach to groundwater. Phosphorous soluble in sodium bicarbonate is the common method for determining plant-available and soil-solution phosphorous, which can then be correlated to fertilizer needs or environmental concerns. Therefore, this analysis was requested since the 1996 soil monitoring. Written notification was received from DEQ that use of the sodium bicarbonate method was appropriate and did not constitute a noncompliance (Rackow 2003a). In 2003, available phosphorous concentrations remained below preapplication concentrations and at concentrations less than that considered adequate for range and pasture crop growth (EPA 1981). 


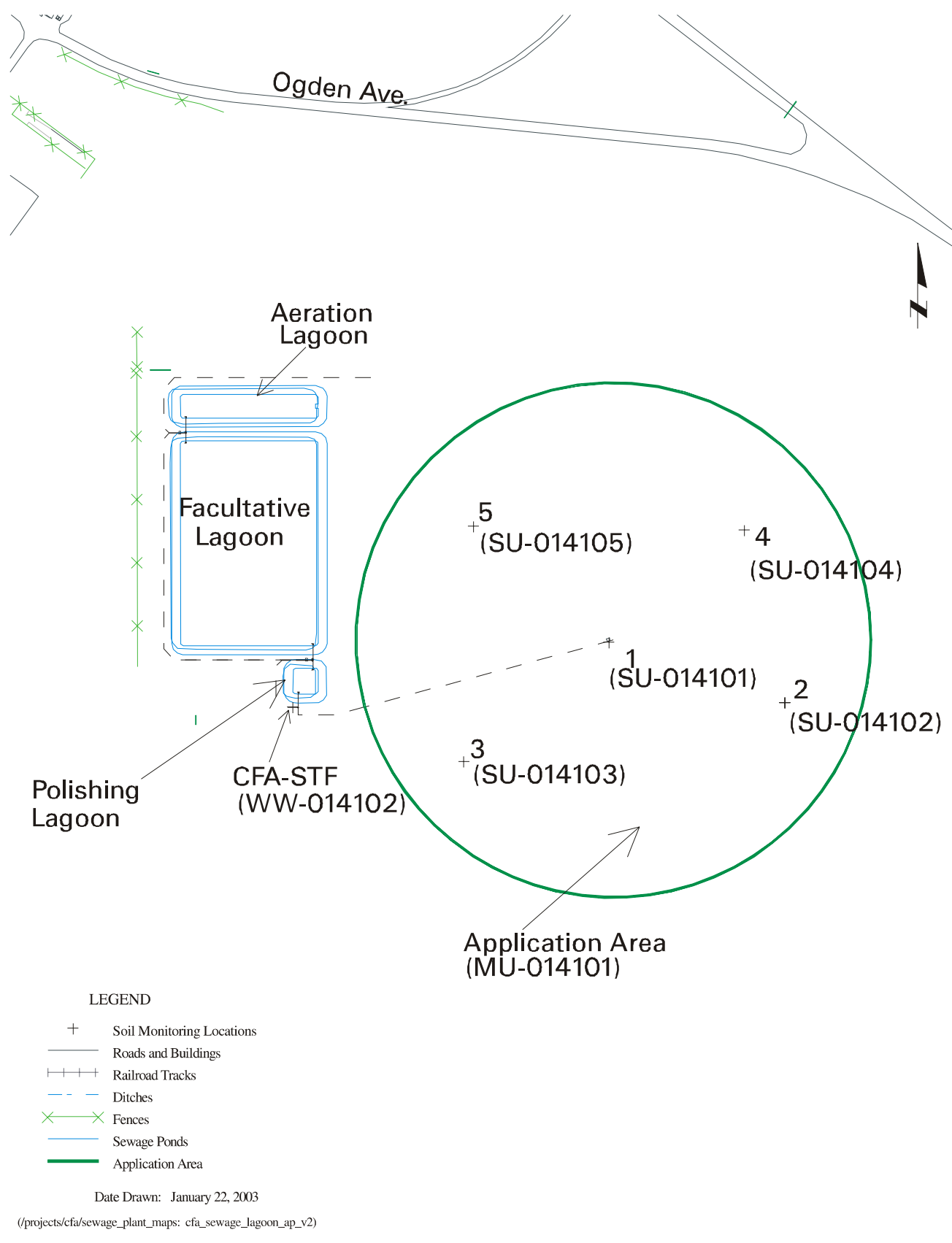

Figure 2-6. Central Facilities Area Wastewater Land Application Permit soil monitoring locations. 
Table 2-7. Central Facilities Area Sewage Treatment Plant application area soil monitoring results.

\begin{tabular}{|c|c|c|c|c|c|c|c|}
\hline \multirow[b]{3}{*}{ Parameter } & \multicolumn{2}{|c|}{$\begin{array}{c}\text { Preapplication } \\
\text { Period }^{\mathrm{a}}\end{array}$} & \multicolumn{5}{|c|}{ Application Period } \\
\hline & \multirow[b]{2}{*}{$\begin{array}{l}\text { Depth } \\
\text { (in.) }\end{array}$} & \multirow[b]{2}{*}{1993} & \multirow[b]{2}{*}{$\begin{array}{l}\text { Depth } \\
\text { (in.) }\end{array}$} & \multicolumn{3}{|c|}{1995 through 2002} & \multirow[b]{2}{*}{2003} \\
\hline & & & & Minimum & Maximum & Average & \\
\hline \multirow[t]{3}{*}{$\mathrm{pH}$} & $0-6$ & 7.6 & $0-12$ & $7.6^{\mathrm{b}}$ & $8.4^{\mathrm{b}}$ & $8.1^{\mathrm{b}}$ & 7.97 \\
\hline & $6-16$ & 8.0 & $12-24$ & $7.6^{\mathrm{b}}$ & $8.6^{\mathrm{b}}$ & $8.2^{\mathrm{b}}$ & 8.02 \\
\hline & $16-30$ & 8.1 & & & & & \\
\hline \multirow{3}{*}{$\begin{array}{l}\text { Electrical } \\
\text { Conductivity } \\
\text { (mmhos/cm) }\end{array}$} & $0-6$ & 0.6 & $0-12$ & 0.36 & 1.20 & 0.77 & 1.22 \\
\hline & $6-16$ & 0.7 & $12-24$ & 0.20 & 1.64 & 0.70 & 1.27 \\
\hline & $16-30$ & 0.6 & & & & & \\
\hline \multirow{3}{*}{$\begin{array}{l}\text { Organic } \\
\text { Matter } \\
(\%)\end{array}$} & $0-6$ & 2.2 & $0-12$ & $0.44^{\mathrm{b}}$ & $3.09^{\mathrm{b}}$ & $1.65^{\mathrm{b}}$ & 1.15 \\
\hline & $6-16$ & 1.6 & $12-24$ & $0.56^{\mathrm{b}}$ & $2.29^{\mathrm{b}}$ & $1.12^{\mathrm{b}}$ & 0.62 \\
\hline & $16-30$ & 1.4 & & & & & \\
\hline \multirow{3}{*}{$\begin{array}{l}\text { Nitrate as } \\
\text { Nitrogen } \\
\text { (ppm) }\end{array}$} & $0-6$ & 16 & $0-12$ & $0.68^{\mathrm{c}}$ & 6.00 & $3.10^{\mathrm{d}}$ & 4.03 \\
\hline & $6-16$ & 6 & $12-24$ & $0.43^{\mathrm{c}}$ & 5.20 & $2.10^{\mathrm{d}}$ & 1.06 \\
\hline & $16-30$ & 3 & & & & & \\
\hline \multirow{3}{*}{$\begin{array}{l}\text { Ammonium } \\
\text { Nitrogen } \\
(\mathrm{ppm})\end{array}$} & $0-6$ & 7.9 & $0-12$ & $0.81 \mathrm{U}^{\mathrm{e}}$ & 6.10 & $3.11^{\mathrm{d}}$ & $4.07 \mathrm{U}$ \\
\hline & $6-16$ & 7.6 & $12-24$ & $0.84 \mathrm{U}$ & 6.00 & $2.76^{\mathrm{d}}$ & $4.00 \mathrm{U}$ \\
\hline & $16-30$ & 7.4 & & & & & \\
\hline \multirow{3}{*}{$\begin{array}{l}\text { Phosphorous } \\
\text { (ppm) }^{\mathrm{f}}\end{array}$} & $0-6$ & 29 & $0-12$ & 3.69 & 12.00 & $7.79^{\mathrm{d}}$ & 8.85 \\
\hline & $6-16$ & 18 & $12-24$ & $2 \mathrm{U}$ & 10.20 & $3.79^{\mathrm{d}}$ & $4.09 \mathrm{U}$ \\
\hline & $16-30$ & 12 & & & & & \\
\hline \multirow{3}{*}{$\begin{array}{l}\text { Sodium } \\
\text { Adsorption } \\
\text { Ratio }\end{array}$} & $0-6$ & 1.0 & $0-12$ & 0.35 & 6.72 & 2.72 & 6.20 \\
\hline & $6-16$ & 1.4 & $12-24$ & 0.31 & 4.03 & 1.59 & 9.12 \\
\hline & $16-30$ & 2.6 & & & & & \\
\hline
\end{tabular}

a. Preapplication sample results were based on a composite of three representative samples taken at each depth. Preapplication soil depths and locations differ from permit samples.

b. The summary statistics shown do not reflect a result from 1995 . While samples were collected in 1995, the analytical laboratory failed to analyze them.

c. The minimum shown is the minimum of the detected results. For the 0-12 in. depth, a result of less than 25 ppm was reported in 1997. For the 12-24 in. depth, a result of less than 1 ppm was reported in 1999, a result of less than 2.25 ppm was reported in both 2000 and 2001, and a result of less than 2.5 ppm was reported in 1997.

d. Where applicable, half the reported detection limit was used to calculate the average.

e. U flag indicates that the reported value for the minimum shown is below the detection limit. In addition, for the 12-24 in. depth, a result of less than 1 ppm was reported in 1998.

f. Available phosphorus was analyzed rather than the total phosphorus analysis specified in the permit. DEQ has indicated that plant available phosphorous is the appropriate soil-monitoring constituent (Rackow 2003a). The total phosphorus reported for 1995 is not included in the summary statistics presented. 


\subsection{Summary of Environmental Impacts}

Operations of the CFA STP continued to have little environmental impact during the 2003 permit year. The relatively weak wastewater influent, followed by treatment in the CFA STP lagoons, produced a good quality effluent for application for the 2003 permit year. When combined with an annual hydraulic loading rate that was lower than that of the design criteria, the nutrient loading rates were below projected levels. Soil and weather conditions, combined with the relatively low volume of wastewater applied during the permit year, resulted in a very low leaching loss $(0.10 \mathrm{in}$.) for the year, compared to the permit limit of 3 in. per year. As a result, land application of wastewater appeared to have negligible impact on soils and groundwater. While SARs were elevated at both depths relative to preapplication SARs, they remain well below those in soils classified with sodium problems.

Evaluations conducted to date into the high nitrate + nitrite concentrations detected in the groundwater near the new STP have determined that the new STP was not the likely source. Since the source is not believed to be the STP, WAG 4 (under the INEEL FFA/CO) will continue to monitor the groundwater nitrate + nitrite concentrations. 
2-16 


\section{IDAHO NUCLEAR TECHNOLOGY AND ENGINEERING CENTER NEW PERCOLATION PONDS DATA SUMMARY AND ASSESSMENT}

\subsection{Site Description}

The Idaho Nuclear Technology and Engineering Center (INTEC) is an approximately 265-acre, multipurpose plant located on the INEEL (Figure 3-1). It was constructed in 1951 and presently includes approximately 280 buildings and structures. Within INTEC are all of the facilities necessary to receive and store spent nuclear fuel, process the fuel to recover uranium-235, and handle waste generated by those functions. However, due to a change in mission in 1992, uranium-235 is no longer recovered at INTEC. Currently, INTEC receives and stores spent nuclear fuel, prepares the spent nuclear fuel for shipment to an off-Site repository, and manages the waste fission products resulting from the spent fuel recovery process. In addition, research and development work is conducted to develop and improve fuel management and waste processing technologies. Environmental restoration and remediation activities are also conducted as part of the INEEL's commitment to clean up the legacy of nuclear operations.

INTEC generates 1 to $2 \mathrm{MG}$ /day on average of process wastewater (commonly called service waste) during normal operations. Prior to August 26, 2002, this wastewater was discharged to Percolation Pond No. 1 or No. 2 (Figure 3-1), referred to as the existing Percolation Ponds, via the service waste system. On August 26, 2002, discharge of this wastewater ceased to the existing Percolation Ponds and was transferred to the New Percolation Ponds (Figure 3-2).

The INTEC New Percolation Ponds receive only discharge of nonhazardous wastewater. Hazardous wastewater from INTEC processes and laboratories is disposed of in accordance with applicable Resource Conservation and Recovery Act (RCRA) regulations. Sanitary wastes from restrooms and the INTEC cafeteria are either discharged to the STP or directed to on-Site septic tank systems.

\subsection{System Description and Operation}

The Comprehensive Environmental Response, Compensation, and Liability Act (CERCLA) Record of Decision for Operable Unit 3-13 (DOE-ID 1999) recommended ceasing use of the existing Percolation Ponds as the preferred alternative to decrease the perched water volume in the subsurface around INTEC. In response to this action, an alternative discharge location was identified approximately 2 miles southwest of INTEC (Figures 3-1 and 3-2). Upon completion of the New Percolation Ponds, the wastewater previously discharged to the existing Percolation Ponds was routed to the New Percolation Ponds on August 26, 2002.

The service waste system serves all major facilities at INTEC. This process-related wastewater from INTEC operations consists of:

- $\quad$ Steam condensates

- $\quad$ Noncontact cooling water

- $\quad$ Reverse osmosis, and water softener and demineralizer regenerate

- $\quad$ Boiler blowdown wastewater

- $\quad$ Other nonhazardous liquids. 


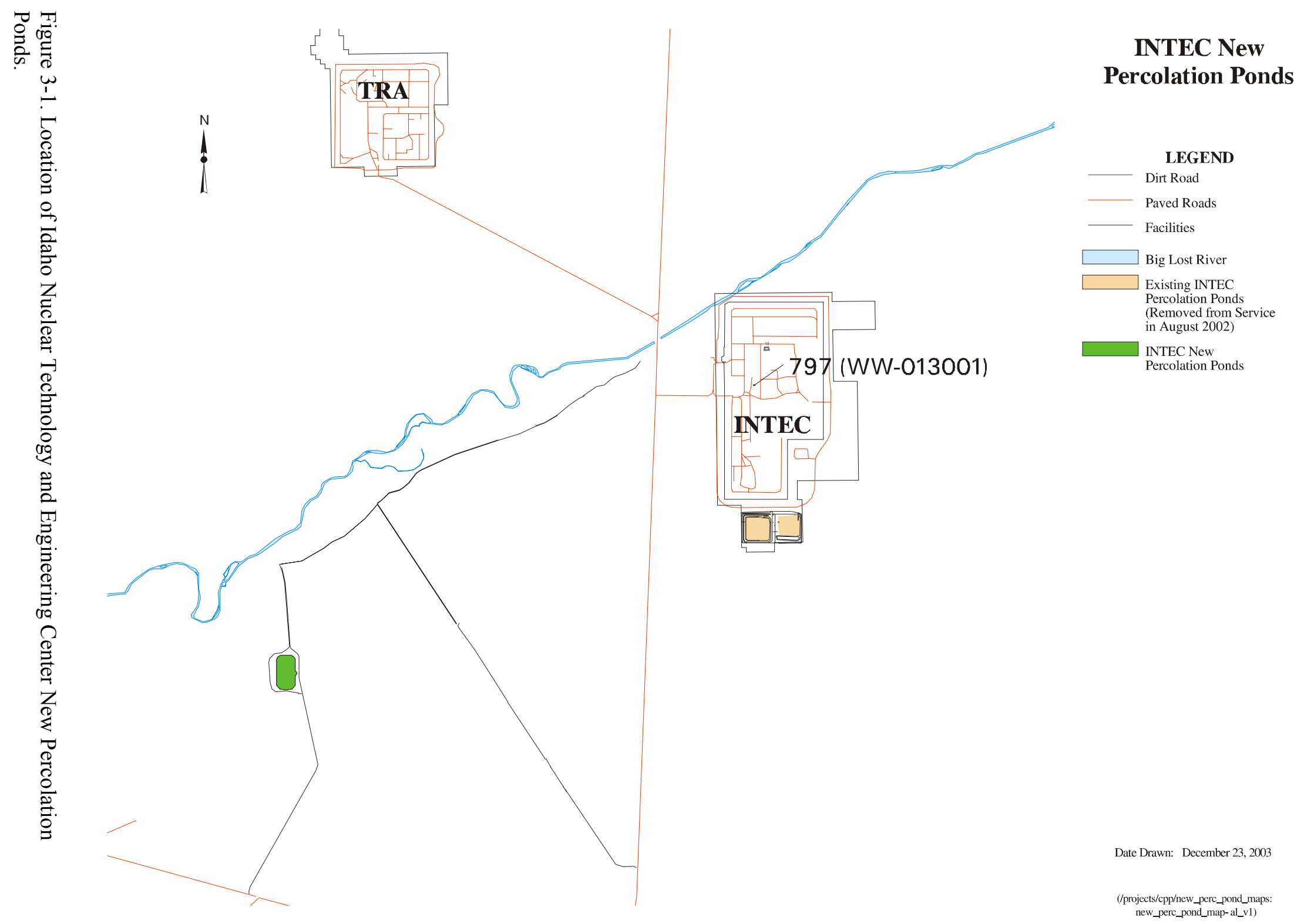




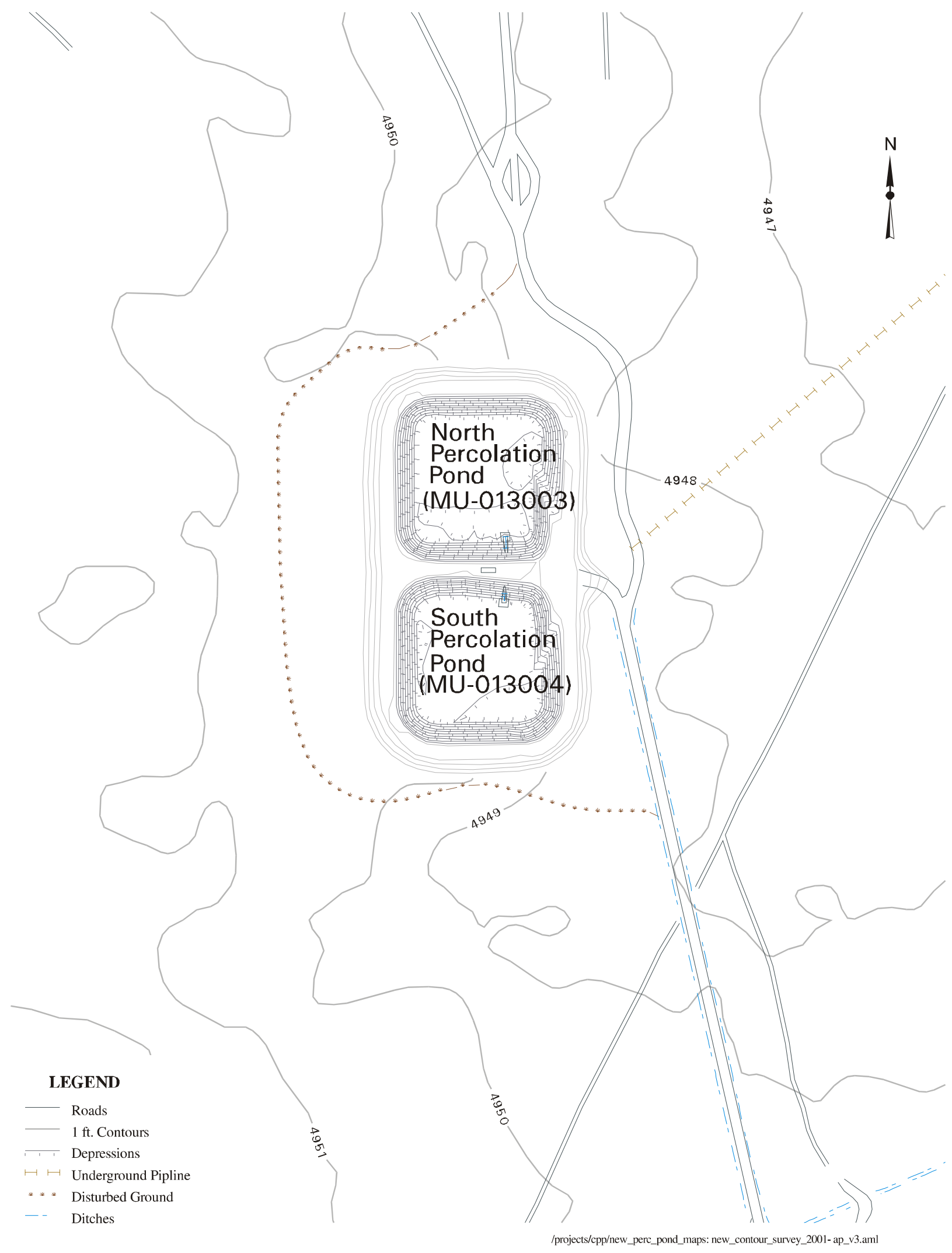

Figure 3-2. Detail of Idaho Nuclear Technology and Engineering Center New Percolation Ponds. 
All service waste entering CPP-797 is discharged to the New Percolation Ponds. In CPP-797, the combined effluent is measured for flow rate, and samples are collected for analyses.

Two sets of electric pumps transfer wastewater from CPP-797 to the New Percolation Ponds. Stainless steel header piping was replaced with high-density polyethylene piping to minimize the effects of microbial corrosion. Two 16-inch lines (primary and redundant) are available to transport the wastewater from CPP-797 to the ponds. Typically, the primary line is used. The redundant line is used as a backup in case the primary line is taken out of service. Additionally, a diesel-driven pumping system is used as the backup for the electric motor systems.

The new pond complex is a rapid infiltration system and is comprised of two ponds excavated into the surficial alluvium and surrounded by bermed alluvial material. Each pond is approximately $305 \times 305$ feet at the top of the berm and is about 10 feet deep. Each pond is designed to accommodate a continuous wastewater discharge rate of approximately 3 million gallons/day.

During normal operation, wastewater is discharged to only one pond at a time. Periodically, the pond receiving the wastewater will be alternated to minimize algae growth and maintain good percolation rates. Ponds are routinely inspected, and the depth is recorded via permanently mounted staff gauges.

\subsection{Status of Special Compliance Conditions}

Section F of the amended WLAP for the New Percolation Ponds (issued March 28, 2002) identifies four special compliance conditions. Compliance activities CA-130-01 and CA-130-04 were completed during the 2002 permit year (INEEL 2003a).

Compliance activity CA-130-02 requires submittal of a final O\&M Manual to the DEQ for review and approval 15 months after startup of the New Percolation Ponds. The manual must incorporate the requirements of the permit and any operational modifications made during the first year of operation, and it must reference written procedures required for operating the system. The New Percolation Ponds became operational on August 26, 2002, making the final O\&M Manual due to DEQ on or before November 26, 2003. On June 26, 2003, a request for a major modification to the New Percolation Pond WLAP and an extension to the completion date for the manual was submitted to DEQ (Guymon 2003b). The major modification would expand the operations associated with the New Percolation Ponds and reroute treated sanitary wastewater from the INTEC STP to the New Percolation Ponds. Because the facility expansion to combine the two effluents would coincide with the submittal and subsequent revision of the manual, an extension on the completion date was requested. Approval for the extension, until 6 months after the new permit is issued, was received in November 2003 after the close of the 2003 permit year (Rackow 2003b).

Compliance activity CA-130-03 requires submittal of a report describing the fate of nutrients (nitrogen and phosphorous) and their potential groundwater impact at the New Percolation Ponds site to the DEQ for review within 12 months after permit issuance. The amended permit for the New Percolation Ponds was issued March 28, 2002, making this report due to DEQ on or before March 28, 2003. The fate of nutrients report was transmitted to DEQ on March 25, 2003 (Guymon 2003c).

\subsection{Effluent Monitoring Results}

The WLAP (LA-000130-03) issued by the DEQ for the New Percolation Ponds specifies a permit year from November 1 through October 31. Compliance samples are collected monthly from CPP-797, based on a random sampling schedule and analyzed for parameters listed in the permit. Table 3-1 presents 
Table 3-1. Idaho Nuclear Technology and Engineering Center New Percolation Ponds effluent data (WW-013001).

\begin{tabular}{|c|c|c|c|c|c|c|c|c|c|c|c|c|c|}
\hline $\begin{array}{c}\text { Sample Month } \\
\text { Sample Date }\end{array}$ & $\begin{array}{r}\text { November } \\
11 / 4 / 2002 \\
\end{array}$ & $\begin{array}{l}\text { December } \\
12 / 2 / 2002 \\
\end{array}$ & $\begin{array}{c}\text { January } \\
1 / 7 / 2003 \\
\end{array}$ & $\begin{array}{c}\text { February } \\
2 / 10 / 2003\end{array}$ & $\begin{array}{c}\text { March } \\
3 / 17 / 2003 \\
\end{array}$ & $\begin{array}{c}\text { April } \\
4 / 8 / 2003 \\
\end{array}$ & $\begin{array}{c}\text { May } \\
5 / 6 / 2003 \\
\end{array}$ & $\begin{array}{c}\text { June } \\
6 / 3 / 2003 \\
\end{array}$ & $\begin{array}{c}\text { July } \\
7 / 14 / 2003 \\
\end{array}$ & $\begin{array}{c}\text { August } \\
8 / 25 / 2003 \\
\end{array}$ & $\begin{array}{c}\text { September } \\
9 / 8 / 2003\end{array}$ & $\begin{array}{c}\text { October } \\
10 / 27 / 2003 \\
\end{array}$ & $\begin{array}{c}\text { Yearly } \\
\text { Average }^{\mathrm{a}}\end{array}$ \\
\hline $\mathrm{pH}$ (grab) & 8.10 & 7.90 & $7.90^{\mathrm{b}}$ & 8.00 & 8.00 & 7.50 & 8.10 & 8.30 & 8.10 & 8.20 & 8.20 & 8.03 & 8.03 \\
\hline $\mathrm{TKN}(\mathrm{mg} / \mathrm{L})$ & $0.24 \mathrm{U}^{\mathrm{c}}$ & $0.24 \mathrm{U}$ & $0.24 \mathrm{U}$ & $0.19 \mathrm{U}$ & $0.19 \mathrm{U}$ & $0.19 \mathrm{U}$ & $0.19 \mathrm{U}$ & $0.19 \mathrm{U}$ & $0.13 \mathrm{U}$ & $0.13 \mathrm{U}$ & $0.13 \mathrm{U}$ & $0.13 \mathrm{U}$ & $0.09 \mathrm{U}$ \\
\hline $\mathrm{NO}_{3}-\mathrm{N}(\mathrm{mg} / \mathrm{L})$ & 0.890 & 0.930 & 0.530 & 0.890 & 0.910 & 1.000 & 0.960 & 0.930 & 0.880 & 0.990 & 1.000 & 0.960 & 0.906 \\
\hline $\mathrm{NO}_{2}-\mathrm{N}(\mathrm{mg} / \mathrm{L})$ & $0.006 \mathrm{U}$ & $3.000 \mathrm{U}$ & $1.700 \mathrm{U}$ & $0.020 \mathrm{U}$ & $0.017 \mathrm{U}$ & $0.004 \mathrm{U}$ & $0.004 \mathrm{U}$ & $0.004 \mathrm{U}$ & $0.004 \mathrm{U}$ & $0.004 \mathrm{U}$ & $0.004 \mathrm{U}$ & $0.006 \mathrm{U}$ & $0.199 \mathrm{U}$ \\
\hline $\begin{array}{l}\text { Total Phosphorous } \\
\text { (mg/L) }\end{array}$ & 0.0231 & 0.0684 & 0.0276 & 0.0219 & 0.0271 & 0.0243 & 0.0242 & 0.0255 & 0.0230 & 0.0200 & 0.0282 & 0.0295 & 0.0286 \\
\hline TDS (mg/L) & 338.0 & $1,265.0$ & $1,210.0$ & 243.0 & 242.0 & 327.0 & 314.0 & 448.0 & 412.0 & 671.0 & 893.0 & 330.0 & 557.8 \\
\hline Chloride $(\mathrm{mg} / \mathrm{L})$ & 76.1 & 806.0 & 647.0 & 15.9 & 17.2 & 72.7 & 67.3 & 139.0 & 132.0 & 278.0 & 427.0 & 73.8 & 229.3 \\
\hline Fluoride (mg/L) & 0.20 & 0.16 & 0.12 & $0.01 \mathrm{U}$ & 0.16 & 0.21 & 0.26 & 0.20 & 0.19 & 0.21 & 0.19 & 0.20 & 0.18 \\
\hline Aluminum (mg/L) & $0.0061 \mathrm{U}$ & 0.0198 & $0.0054 \mathrm{U}$ & $0.0054 \mathrm{U}$ & $0.0093 \mathrm{U}$ & $0.0093 \mathrm{U}$ & $0.0093 \mathrm{U}$ & $0.0107 \mathrm{U}$ & 0.0121 & $0.0107 \mathrm{U}$ & $0.0073 \mathrm{U}$ & $0.0077 \mathrm{U}$ & 0.0060 \\
\hline Arsenic (mg/L) & $0.0043 \mathrm{U}$ & $0.0049 \mathrm{U}$ & $0.0040 \mathrm{U}$ & $0.0040 \mathrm{U}$ & $0.0043 \mathrm{U}$ & $0.0043 \mathrm{U}$ & $0.0043 \mathrm{U}$ & $0.0043 \mathrm{U}$ & $0.0035 \mathrm{U}$ & $0.0043 \mathrm{U}$ & $0.0053 \mathrm{U}$ & $0.0047 \mathrm{U}$ & $0.0022 \mathrm{U}$ \\
\hline Cadmium (mg/L) & $0.0006 \mathrm{U}$ & $0.0006 \mathrm{U}$ & 0.0004 & $0.0003 \mathrm{U}$ & $0.0004 \mathrm{U}$ & $0.0004 \mathrm{U}$ & $0.0004 \mathrm{U}$ & $0.0007 \mathrm{U}$ & $0.0004 \mathrm{U}$ & $0.0007 \mathrm{U}$ & $0.0004 \mathrm{U}$ & 0.0021 & 0.0004 \\
\hline Chromium (mg/L) & 0.0057 & 0.0072 & 0.0057 & 0.0056 & 0.0060 & 0.0058 & 0.0063 & 0.0063 & 0.0060 & 0.0056 & 0.0058 & 0.0060 & 0.0060 \\
\hline Copper (mg/L) & 0.0043 & 0.0112 & 0.0036 & 0.0022 & 0.0104 & 0.0046 & 0.0069 & 0.0019 & 0.0025 & $0.0009 \mathrm{U}$ & 0.0033 & 0.0026 & 0.0045 \\
\hline Iron $(\mathrm{mg} / \mathrm{L})$ & $0.0161 \mathrm{U}$ & 0.2780 & $0.0132 \mathrm{U}$ & 0.0111 & 0.0302 & 0.0198 & $0.0107 \mathrm{U}$ & 0.0190 & 0.0141 & $0.0055 \mathrm{U}$ & 0.0096 & $0.0063 \mathrm{U}$ & 0.0340 \\
\hline Manganese $(\mathrm{mg} / \mathrm{L})$ & 0.0008 & 0.0032 & 0.0005 & 0.0005 & 0.0009 & 0.0010 & 0.0008 & 0.0007 & 0.0009 & $0.0003 \mathrm{U}$ & 0.0005 & $0.0003 \mathrm{U}$ & 0.0008 \\
\hline Mercury (mg/L) & $0.0001 \mathrm{U}$ & $0.0001 \mathrm{U}$ & $0.0001 \mathrm{U}$ & $0.0001 \mathrm{U}$ & $0.0001 \mathrm{U}$ & $0.0001 \mathrm{U}$ & $0.0001 \mathrm{U}$ & $0.0001 \mathrm{U}$ & $0.0001 \mathrm{U}$ & $0.0001 \mathrm{U}$ & $0.0001 \mathrm{U}$ & $0.0001 \mathrm{U}$ & $0.0001 \mathrm{U}$ \\
\hline Selenium (mg/L) & $0.0030 \mathrm{U}$ & 0.0046 & $0.0036 \mathrm{U}$ & $0.0036 \mathrm{U}$ & $0.0039 \mathrm{U}$ & $0.0039 \mathrm{U}$ & $0.0039 \mathrm{U}$ & $0.0037 \mathrm{U}$ & $0.0038 \mathrm{U}$ & $0.0037 \mathrm{U}$ & $0.0035 \mathrm{U}$ & $0.0049 \mathrm{U}$ & 0.0021 \\
\hline Silver (mg/L) & $0.0020 \mathrm{U}$ & $0.0030 \mathrm{U}$ & $0.0015 \mathrm{U}$ & $0.0015 \mathrm{U}$ & $0.0017 \mathrm{U}$ & $0.0017 \mathrm{U}$ & $0.0017 \mathrm{U}$ & $0.0016 \mathrm{U}$ & $0.0022 \mathrm{U}$ & $0.0016 \mathrm{U}$ & $0.0032 \mathrm{U}$ & $0.0016 \mathrm{U}$ & $0.0010 \mathrm{U}$ \\
\hline Sodium $(\mathrm{mg} / \mathrm{L})$ & 64.1 & 95.8 & 351.0 & 39.2 & 43.1 & 46.8 & 69.6 & 57.6 & 58.1 & 172.0 & 258.0 & 61.8 & 109.8 \\
\hline \multicolumn{14}{|c|}{$\begin{array}{l}\text { a. Yearly average is determined from the average of the monthly values. Half the detection limit was used in the yearly average calculations for those results reported as below the detection limit for those parameters with varying detection limits. For mercury, the detection limit } \\
\text { did not vary and the yearly average reflects the detection limit. }\end{array}$} \\
\hline $\begin{array}{ll}\text { b. The result shown } \\
\text { c. }\end{array}$ & & & & & & & & & 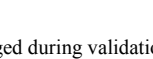 & & & & \\
\hline
\end{tabular}


effluent water quality data applicable to the New Percolation Ponds for the 2003 permit year. A 24-hour flow-proportional composite sample was collected from the sample point in CPP-797 for all parameters except $\mathrm{pH}$, which was taken as a grab sample as required by the permit.

The permit for the New Percolation Ponds does not specify concentration limits for the effluent to the ponds. However, in order to aid in monitoring plant efficiency, effluent concentrations were compared to the groundwater quality standards. During permit year 2003, when comparing the effluent concentrations to the groundwater quality standards as an indicator of plant efficiency, only TDS and chloride fell above the standards (during 4 months of the permit year). However, because no permit limits are set for the effluent, these levels do not reflect permit noncompliances. During these same 4 months, the sodium concentrations in the effluent were also high and the TDS, chloride, and sodium concentrations were some of the highest reported to date for the CPP-797 service waste effluent. High concentrations of TDS, chloride, and sodium in the service waste effluent are usually indicative of a problem with the CPP-606 water treatment system. During the permit year, several evaluations were conducted in support of a project to upgrade the current INTEC water treatment system. These evaluations included a survey of the treated water demands, water quality requirements, and candidate conservation measures. Several design options to upgrade the water treatment system are currently being evaluated.

\subsubsection{Flow Volumes}

The flow volumes to the New Percolation Ponds were recorded daily from the flow meter in CPP-797. Table 3-2 presents monthly and total flow volumes for the permit year, and Appendix B presents daily flow readings and copies of the required electronic WLAP data files (DEQ 2002a). From the start of the permit year until August 1, 2003, all flow was directed to the north pond (MU-013003). From August 1, 2003, until the end of the permit year, all flow was directed to the south pond (MU-013004). During the 2003 permit year, daily flow was below $2 \mathrm{MG} /$ day and total flow (approximately $500 \mathrm{MG} /$ year) was well below the permit limit of 1,095 MG/year.

\subsection{Evaluation of Water Quality Testing for the Weapons Range}

Section $\mathrm{G}$ of the WLAP requires reporting of water quality testing results for the Weapons Range drinking water well as required by the DEQ Drinking Water Program. The sampling location for the Weapons Range drinking water well was clarified by DEQ to be the point of compliance at Building B21-608 (Allred 2001). The water quality of the Weapons Range B21-608 Building is monitored by the INEEL Drinking Water Program in accordance with the DEQ Drinking Water Program. The Weapons Range is considered a transient, noncommunity water system. As such, monitoring is required yearly for nitrates and quarterly for bacteria. The Weapons Range water system is a chlorinated system.

The annual nitrate sample of the Weapons Range distribution system was collected on June 24,2003 . The concentration of nitrate was $0.81 \mathrm{mg} / \mathrm{L}$, well below the primary constituent standard of $10 \mathrm{mg} / \mathrm{L}$.

Quarterly sampling of bacteria is required of the Weapons Range water system. As a best management practice, the INEEL Drinking Water Program samples more frequently than quarterly. During the 2003 permit year, the Weapons Range water system was sampled monthly for bacteria. No bacteria were detected in the Weapons Range water system during the 2003 permit year. 
Table 3-2. Idaho Nuclear Technology and Engineering Center New Percolation Ponds flow summaries.

\begin{tabular}{|c|c|c|c|c|c|c|}
\hline \multirow[b]{2}{*}{ Sample Month } & \multicolumn{3}{|c|}{$\begin{array}{l}\text { Effluent (WW-013001) } \\
\left(\mathrm{gpd}^{\mathrm{a}}\right)\end{array}$} & \multicolumn{3}{|c|}{$\begin{array}{c}\text { Total } \\
\left(\mathrm{MG}^{\mathrm{b}}\right)\end{array}$} \\
\hline & Average & Minimum & Maximum & $\begin{array}{l}\text { North Pond } \\
\text { (MU-013003) }\end{array}$ & $\begin{array}{l}\text { South Pond } \\
\text { (MU-013004) }\end{array}$ & $\begin{array}{c}\text { North \& South } \\
\text { Ponds }\end{array}$ \\
\hline November 2002 & $1,643,503$ & $1,489,600$ & $1,853,200$ & 49.305 & $\mathrm{NF}^{\mathrm{c}}$ & 49.305 \\
\hline December 2002 & $1,553,445$ & $1,478,200$ & $1,625,200$ & 48.157 & NF & 48.157 \\
\hline January 2003 & $1,558,326$ & $1,519,300$ & $1,662,400$ & 48.308 & $\mathrm{NF}$ & 48.308 \\
\hline February 2003 & $1,530,764$ & $1,400,200$ & $1,626,200$ & 42.861 & $\mathrm{NF}$ & 42.861 \\
\hline March 2003 & $1,412,507$ & $1,376,700$ & $1,451,900$ & 43.788 & $\mathrm{NF}$ & 43.788 \\
\hline April 2003 & $1,361,177$ & 763,200 & $1,485,000$ & 40.835 & $\mathrm{NF}$ & 40.835 \\
\hline May 2003 & $1,278,319$ & $1,017,200$ & $1,505,400$ & 39.628 & $\mathrm{NF}$ & 39.628 \\
\hline June 2003 & $1,428,827$ & $1,240,900$ & $1,552,400$ & 42.865 & $\mathrm{NF}$ & 42.865 \\
\hline July 2003 & $1,442,555$ & $1,287,200$ & $1,562,400$ & 44.719 & $\mathrm{NF}$ & 44.719 \\
\hline August 2003 & $1,083,097$ & 663,400 & $1,280,500$ & $\mathrm{NF}$ & 33.576 & 33.576 \\
\hline September 2003 & $1,019,060$ & 863,000 & $1,128,900$ & $\mathrm{NF}$ & 30.572 & 30.572 \\
\hline October 2003 & $1,153,898$ & 766,200 & $1,299,100$ & $\mathrm{NF}$ & 35.771 & 35.771 \\
\hline Yearly Summary & $1,372,123$ & 663,400 & $1,853,200$ & 400.470 & 99.919 & 500.385 \\
\hline $\begin{array}{l}\text { b. Monthly and ann } \\
\text { c. NF-No flow to }\end{array}$ & $\begin{array}{l}\text { Is are shown } \\
\text { ad occurred d }\end{array}$ & $\begin{array}{l}\text { lion gallons }( \\
\text { the month. }\end{array}$ & & & & \\
\hline
\end{tabular}

\subsection{Evaluation of Groundwater Data}

To measure potential impacts to groundwater from the New Percolation Ponds, the permit requires that groundwater samples be collected from six monitoring wells (see Figure 3-3):

- One background aquifer well (ICPP-MON-A-167) upgradient of the New Percolation Ponds.

- One background perched water well (ICPP-MON-V-191) north of the New Percolation Ponds and just south of the Big Lost River.

- Two aquifer wells (ICPP-MON-A-165 and -166) downgradient of the New Percolation Ponds.

- $\quad$ Two perched water wells (ICPP-MON-V-200 and ICPP-MON-V-212) adjacent to the New Percolation Ponds. Well ICPP-MON-V-200 is north of the New Percolation Ponds, and well ICPP-MON-V-212 is between the two ponds.

The permit requires that samples be collected semiannually during April and October and provides a specified list of parameters to be analyzed for in the groundwater samples. Aquifer wells ICPP-MON-A-165 and ICPP-MON-A-166 and perched water wells ICPP-MON-V-200 and ICPP-MON-V-212 are the permit compliance points. Aquifer well ICPP-MON-A-167 and perched water 


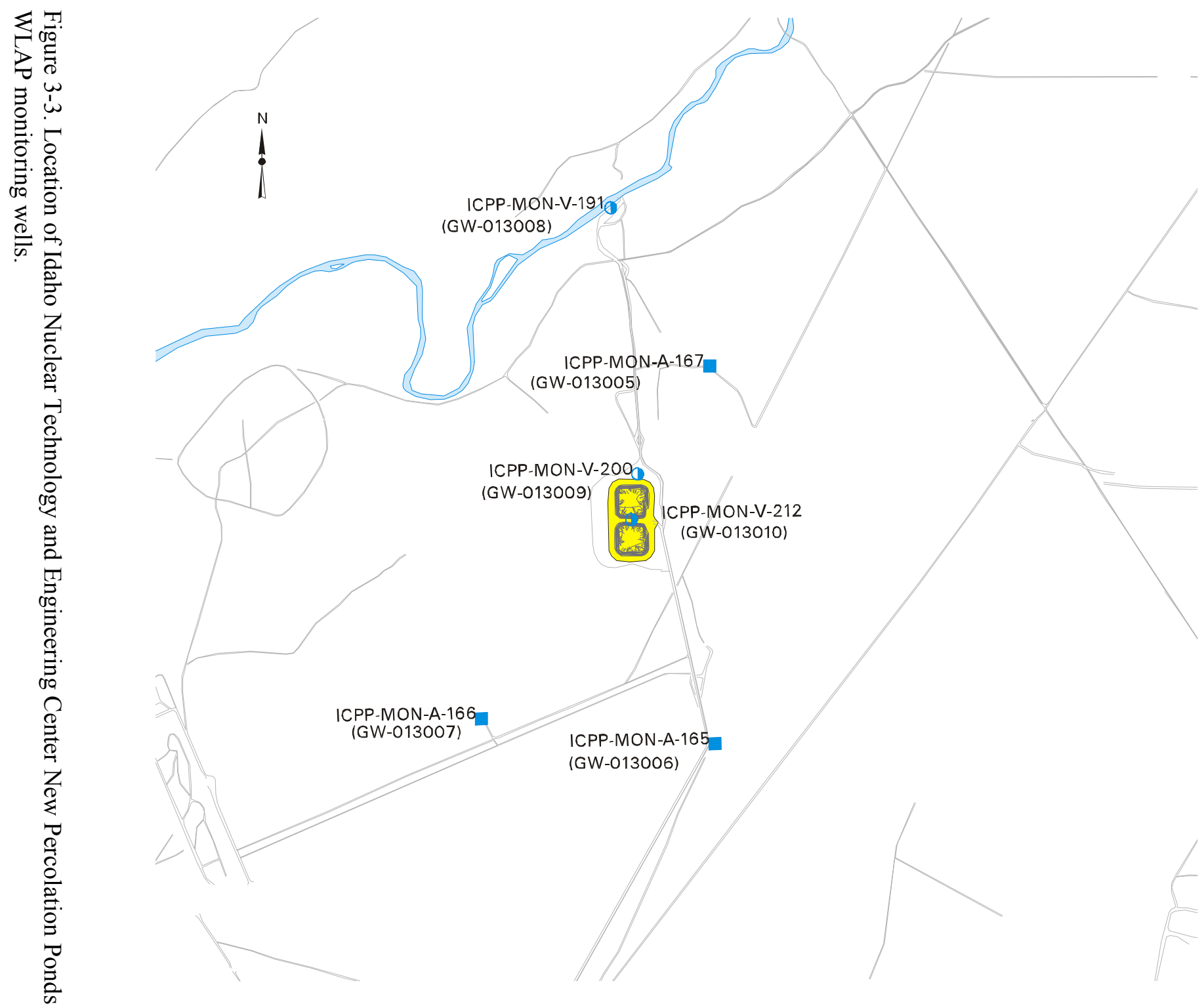

INTEC New

Percolation Ponds

\section{LEGEND}

- Perched Water Wells

- Aquifer Wells

Dirt Road

$\square$ Big Lost River

$\square$ Big Lost River
$\square$ INTEC New

Percolation Pond 
well ICPP-MON-V-191 are listed in the permit as upgradient, noncompliance points. Contaminant concentrations in the compliance wells are limited by the primary constituent standards (PCSs) and secondary constituent standards (SCSs) in IDAPA 58.01.11. All permit-required samples are collected as unfiltered samples.

Tables 3-3 and 3-4 show water levels (recorded prior to purging and sampling) and analytical results for all parameters specified by the permit for aquifer and perched water wells, respectively. Samples were collected from wells ICPP-MON-A-165, ICPP-MON-A-166, ICPP-MON-A-167, ICPP-MON-V-200, and ICPP-MON-V-212. Perched water well ICPP-MON-V-191 was dry during both the April and October 2003 sampling events. Well ICPP-MON-V-191 is expected to remain dry until there is sufficient flow in the Big Lost River to recharge the perched water at this well.

Perched water wells ICPP-MON-V-200 and ICPP-MON-V-212 were dry prior to discharge of service waste wastewater into the new ponds. Discharge of wastewater began on August 26, 2002. After approximately $1 \frac{1}{2}$ months of wastewater disposal to the ponds, a sufficient volume of water had accumulated in well ICPP-MON-V-200 to collect samples in October 2002. The data from this sampling event indicated that no PCS or SCS levels were exceeded. Samples were collected again in April and October 2003 (Table 3-4). The sample results show that the TDS concentration has increased from $323 \mathrm{mg} / \mathrm{L}$ in October 2002, to $407 \mathrm{mg} / \mathrm{L}$ in April 2003, and to $554 \mathrm{mg} / \mathrm{L}$ in October 2003. The October 2003 TDS sample result was above the SCS of $500 \mathrm{mg} / \mathrm{L}$. Although chloride has not exceeded its respective SCS $(250 \mathrm{mg} / \mathrm{L})$, the chloride concentration has also increased from $33.6 \mathrm{mg} / \mathrm{L}$ in October 2002 to $213 \mathrm{mg} / \mathrm{L}$ in October 2003. Sodium concentrations have also increased over time in this well. The increase in these parameters has likely been caused by the effluent concentrations in the service waste wastewater and the application of this wastewater to the New Percolation Ponds. Aluminum and iron concentrations in well ICPP-MON-V-200 were also above their respective SCSs. These parameters will be discussed in further detail later in this section.

Perched water well ICPP-MON-V-212 had insufficient volume to collect a sample in October 2002. Therefore, the first samples from this well were obtained in April 2003. Samples were also collected in October 2003. No parameters from these two sampling events were above their respective PCS or SCS. However, TDS, chloride, and sodium concentrations appear to be increasing. Both TDS and chloride were significantly higher in well ICPP-MON-V-212 (Table 3-4) than in upgradient well ICPP-MON-A-167 (Table 3-3).

The concentrations for aluminum, iron, and manganese were above the SCSs in aquifer well ICPP-MON-A-167 in both April 2003 and October 2003 (Table 3-3). Well ICPP-MON-A-166 exceeded the SCSs for aluminum and manganese in April 2003 (Guymon 2003d) and October 2003 (Gibby 2004), and for iron in October 2003 (Gibby 2004). Well ICPP-MON-A-166 is a compliance monitoring well and is regulated by the permit not to exceed the PCSs and SCSs. Well ICPP-MON-A-167 is the background aquifer monitoring well and is not regulated to these standards by the permit.

Concentrations of aluminum and iron in well ICPP-MON-A-166 in October 2003 (Table 3-3) increased from those in April 2003 and were higher than those in the preoperational baseline samples for this well (Table 3-5). The manganese concentrations in April 2003 and October 2003 were lower than preoperational baseline concentrations.

The aluminum, iron, and manganese concentrations in April 2003 and October 2003 from well ICPP-MON-A-167 were lower than preoperational baseline concentrations (Table 3-5). And while the aluminum concentrations from April 2003 and October 2003 were similar to the October 2002 
Table 3-3. Idaho Nuclear Technology and Engineering Center New Percolation Ponds groundwater quality data from aquifer wells for April and October 2003.

\begin{tabular}{|c|c|c|c|c|c|c|c|c|c|}
\hline \multirow{2}{*}{$\begin{array}{l}\text { Depth to Water } \\
\text { Table (ft) }\end{array}$} & \multicolumn{3}{|c|}{$\begin{array}{l}\text { ICPP-MON-A-167 } \\
\text { (GW-013005) }\end{array}$} & \multicolumn{2}{|c|}{$\begin{array}{l}\text { ICPP-MON-A-165 } \\
(\mathrm{GW}-013006)\end{array}$} & \multicolumn{3}{|c|}{$\begin{array}{c}\text { ICPP-MON-A-166 } \\
\text { (GW-013007) }\end{array}$} & \multirow{2}{*}{$\mathrm{PCS} / \mathrm{SCS}^{\mathrm{a}}$} \\
\hline & 495.53 & 495.29 & 495.29 & 500.62 & 500.62 & 505.13 & 505.13 & 506.48 & \\
\hline $\begin{array}{l}\text { Sample Date } \\
\left.\text { (units }{ }^{b}\right)\end{array}$ & $\begin{array}{c}4 / 14 / 2003 \\
(\mathrm{mg} / \mathrm{L})\end{array}$ & $\begin{array}{c}10 / 6 / 2003 \\
(\mathrm{mg} / \mathrm{L})\end{array}$ & $\begin{array}{c}10 / 6 / 2003^{\mathrm{c}} \\
(\mathrm{mg} / \mathrm{L})\end{array}$ & $\begin{array}{c}4 / 15 / 2003 \\
(\mathrm{mg} / \mathrm{L})\end{array}$ & $\begin{array}{c}10 / 6 / 2003 \\
(\mathrm{mg} / \mathrm{L})\end{array}$ & $\begin{array}{c}4 / 14 / 2003 \\
(\mathrm{mg} / \mathrm{L})\end{array}$ & $\begin{array}{c}4 / 14 / 2003^{\mathrm{c}} \\
(\mathrm{mg} / \mathrm{L})\end{array}$ & $\begin{array}{c}10 / 6 / 2003 \\
(\mathrm{mg} / \mathrm{L})\end{array}$ & $(\mathrm{mg} / \mathrm{L})$ \\
\hline $\mathrm{pH}$ & 8.46 & 7.88 & 7.88 & 8.20 & 7.55 & 8.06 & 8.06 & 7.52 & $6.5-8.5$ \\
\hline TKN & $0.90 \mathrm{U}^{\mathrm{d}}$ & $1.0 \mathrm{U}$ & $1.0 \mathrm{U}$ & $1.8 \mathrm{U}$ & $1.0 \mathrm{U}$ & $0.90 \mathrm{U}$ & $0.90 \mathrm{U}$ & $1.0 \mathrm{U}$ & $\mathrm{NA}^{\mathrm{e}}$ \\
\hline $\mathrm{NO}_{3}-\mathrm{N}$ & 0.48 & 0.46 & 0.43 & 0.76 & 0.62 & 0.26 & 0.23 & 0.14 & 10 \\
\hline $\mathrm{NO}_{2}-\mathrm{N}$ & $0.10 \mathrm{U}$ & $0.10 \mathrm{U}$ & $0.10 \mathrm{U}$ & $0.10 \mathrm{U}$ & $0.10 \mathrm{U}$ & $0.10 \mathrm{U}$ & $0.10 \mathrm{U}$ & $0.10 \mathrm{U}$ & 1 \\
\hline Total Phosphorous & 0.20 & 0.31 & 0.27 & 0.074 & $0.10 \mathrm{U}$ & $0.03 \mathrm{U}$ & 0.062 & $0.10 \mathrm{U}$ & NA \\
\hline TDS & 205 & 203 & 213 & 224 & 234 & 185 & 175 & 178 & 500 \\
\hline Chloride & 12.5 & 7.1 & 7.2 & 16.2 & 17.5 & 6.8 & 13.6 & 6.8 & 250 \\
\hline Fluoride & 0.19 & 0.11 & 0.13 & 0.21 & 0.12 & 0.26 & 0.24 & 0.14 & 4 \\
\hline Aluminum & 6.61 & 5.82 & 6.74 & $0.025 \mathrm{U}$ & $0.025 \mathrm{U}$ & 0.199 & 0.231 & 1.06 & 0.2 \\
\hline Aluminum-filtered & $\mathrm{NT}^{\mathrm{f}}$ & 0.0362 & 0.0392 & NT & NT & NT & NT & $0.025 \mathrm{U}$ & 0.2 \\
\hline Arsenic & 0.0026 & 0.0033 & $0.0025 \mathrm{U}$ & $0.0025 \mathrm{U}$ & $0.0025 \mathrm{U}$ & $0.0025 \mathrm{U}$ & $0.0025 \mathrm{U}$ & $0.0025 \mathrm{U}$ & 0.05 \\
\hline Arsenic-filtered & NT & $0.0025 \mathrm{U}$ & $0.0033 \mathrm{U}$ & NT & NT & NT & NT & $0.0025 \mathrm{U}$ & 0.05 \\
\hline Cadmium & $0.001 \mathrm{U}$ & $0.001 \mathrm{U}$ & $0.001 \mathrm{U}$ & $0.001 \mathrm{U}$ & $0.001 \mathrm{U}$ & $0.001 \mathrm{U}$ & $0.001 \mathrm{U}$ & $0.001 \mathrm{U}$ & 0.005 \\
\hline Cadmium-filtered & NT & $0.001 \mathrm{U}$ & $0.001 \mathrm{U}$ & NT & NT & NT & NT & $0.001 \mathrm{U}$ & 0.005 \\
\hline Chromium & 0.0136 & 0.0147 & 0.0186 & 0.0105 & 0.0084 & 0.0078 & 0.0091 & 0.0177 & 0.1 \\
\hline Chromium-filtered & NT & 0.0053 & $0.0063 \mathrm{U}$ & NT & NT & NT & NT & 0.0052 & 0.1 \\
\hline
\end{tabular}


Table 3-3. (continued).

\begin{tabular}{|c|c|c|c|c|c|c|c|c|c|}
\hline \multirow{2}{*}{$\begin{array}{l}\text { Depth to Water } \\
\text { Table (ft) }\end{array}$} & \multicolumn{3}{|c|}{$\begin{array}{l}\text { ICPP-MON-A-167 } \\
\text { (GW-013005) }\end{array}$} & \multicolumn{2}{|c|}{$\begin{array}{l}\text { ICPP-MON-A-165 } \\
(\mathrm{GW}-013006)\end{array}$} & \multicolumn{3}{|c|}{$\begin{array}{l}\text { ICPP-MON-A-166 } \\
\text { (GW-013007) }\end{array}$} & \multirow{3}{*}{$\begin{array}{l}\mathrm{PCS} / \mathrm{SCS}^{\mathrm{a}} \\
(\mathrm{mg} / \mathrm{L})\end{array}$} \\
\hline & 495.53 & 495.29 & 495.29 & 500.62 & 500.62 & 505.13 & 505.13 & 506.48 & \\
\hline $\begin{array}{l}\text { Sample Date } \\
\left.\text { (units }{ }^{b}\right)\end{array}$ & $\begin{array}{c}4 / 14 / 2003 \\
(\mathrm{mg} / \mathrm{L})\end{array}$ & $\begin{array}{c}10 / 6 / 2003 \\
(\mathrm{mg} / \mathrm{L})\end{array}$ & $\begin{array}{c}10 / 6 / 2003^{\mathrm{c}} \\
(\mathrm{mg} / \mathrm{L})\end{array}$ & $\begin{array}{c}4 / 15 / 2003 \\
(\mathrm{mg} / \mathrm{L})\end{array}$ & $\begin{array}{c}10 / 6 / 2003 \\
(\mathrm{mg} / \mathrm{L})\end{array}$ & $\begin{array}{c}4 / 14 / 2003 \\
(\mathrm{mg} / \mathrm{L})\end{array}$ & $\begin{array}{c}4 / 14 / 2003^{\mathrm{c}} \\
(\mathrm{mg} / \mathrm{L})\end{array}$ & $\begin{array}{c}10 / 6 / 2003 \\
(\mathrm{mg} / \mathrm{L})\end{array}$ & \\
\hline Copper & 0.0157 & 0.0174 & 0.0182 & $0.001 \mathrm{U}$ & 0.0014 & $0.001 \mathrm{U}$ & $0.001 \mathrm{U}$ & 0.004 & 1.3 \\
\hline Copper-filtered & NT & 0.0013 & 0.0017 & NT & NT & NT & NT & $0.001 \mathrm{U}$ & 1.3 \\
\hline Iron & 3.92 & 3.68 & 4.13 & 0.0613 & 0.0655 & 0.217 & 0.238 & 0.939 & 0.3 \\
\hline Iron-filtered & NT & 0.077 & 0.0824 & NT & NT & NT & NT & 0.0612 & 0.3 \\
\hline Manganese & 0.0696 & 0.0681 & 0.0758 & $0.0025 \mathrm{U}$ & $0.0025 \mathrm{U}$ & 0.0697 & 0.0692 & 0.072 & 0.05 \\
\hline Manganese-filtered & NT & 0.009 & 0.0098 & NT & NT & NT & NT & 0.0376 & 0.05 \\
\hline Mercury & $0.0002 \mathrm{U}$ & $0.0002 \mathrm{U}$ & $0.0002 \mathrm{U}$ & $0.0002 \mathrm{U}$ & $0.0002 \mathrm{U}$ & $0.0002 \mathrm{U}$ & $0.0002 \mathrm{U}$ & $0.0002 \mathrm{U}$ & 0.002 \\
\hline Mercury-filtered & NT & $0.0002 \mathrm{U}$ & $0.0002 \mathrm{U}$ & NT & NT & NT & NT & $0.0002 \mathrm{U}$ & 0.002 \\
\hline Selenium & $0.0025 \mathrm{U}$ & $0.0025 \mathrm{U}$ & $0.0025 \mathrm{U}$ & $0.0025 \mathrm{U}$ & $0.0025 \mathrm{U}$ & $0.0025 \mathrm{U}$ & $0.0025 \mathrm{U}$ & $0.0025 \mathrm{U}$ & 0.05 \\
\hline Selenium -filtered & NT & $0.0025 \mathrm{U}$ & $0.0025 \mathrm{U}$ & NT & NT & NT & NT & $0.0025 \mathrm{U}$ & 0.05 \\
\hline Silver & $0.0025 \mathrm{U}$ & $0.0025 \mathrm{U}$ & $0.0025 \mathrm{U}$ & $0.0025 \mathrm{U}$ & $0.0025 \mathrm{U}$ & $0.0025 \mathrm{U}$ & $0.0025 \mathrm{U}$ & $0.0025 \mathrm{U}$ & 0.1 \\
\hline Silver-filtered & NT & $0.0025 \mathrm{U}$ & $0.0025 \mathrm{U}$ & NT & NT & NT & NT & $0.0025 \mathrm{U}$ & 0.1 \\
\hline Sodium & 13.4 & 13.9 & 14.0 & 8.08 & 10.0 & 9.15 & 9.22 & 9.75 & NA \\
\hline Sodium-filtered & NT & 12.7 & 12.9 & NT & NT & NT & NT & 9.66 & NA \\
\hline $\begin{array}{ll}\text { a. } & \text { Primary constituent } \\
\text { b. The units for all par } \\
\text { c. Duplicate sample. } \\
\text { d. U flag indicates that } \\
\text { e. NA-Not applicabl } \\
\text { f. NT-No filtered me }\end{array}$ & $\begin{array}{l}\text { standards (PCS } \\
\text { ameters listed a } \\
\text { the result was } \\
\text { e. } \\
\text { tal sample was }\end{array}$ & $\begin{array}{l}\text { eported as belo } \\
\text { aken. }\end{array}$ & $\begin{array}{l}\text { onstituent stand } \\
\text { pt for } \mathrm{pH} \text { which }\end{array}$ & $\begin{array}{l}\text { ds (SCS) in grou } \\
\text { unitless. }\end{array}$ & dwater referenc & in IDAPA $58 .($ & $1.11 .200 .01 . \mathrm{a}$ an & & \\
\hline
\end{tabular}


Table 3-4. Idaho Nuclear Technology and Engineering Center New Percolation Ponds groundwater quality data from perched water wells for April and October 2003.

\begin{tabular}{|c|c|c|c|c|c|c|c|}
\hline \multirow{2}{*}{$\begin{array}{c}\text { Depth to Water } \\
\text { Table }(\mathrm{ft})\end{array}$} & \multicolumn{2}{|c|}{$\begin{array}{l}\text { ICPP-MON-V-191 } \\
(\mathrm{GW}-013008)\end{array}$} & \multicolumn{2}{|c|}{$\begin{array}{l}\text { ICPP-MON-V-200 } \\
(\mathrm{GW}-013009)\end{array}$} & \multicolumn{2}{|c|}{$\begin{array}{c}\text { ICPP-MON-V-212 } \\
(\mathrm{GW}-013010)\end{array}$} & \multirow[t]{2}{*}{$\mathrm{PCS} / \mathrm{SCS}^{\mathrm{a}}$} \\
\hline & Dry $^{\mathrm{b}}$ & Dry $^{b}$ & 117.85 & 111.04 & 238.25 & 234.94 & \\
\hline $\begin{array}{c}\text { Sample Date } \\
\left(\text { units }^{\mathrm{c}}\right)\end{array}$ & $\begin{array}{c}\text { April } 2003 \\
\text { Not Sampled }\end{array}$ & $\begin{array}{l}\text { October } 2003 \\
\text { Not Sampled }\end{array}$ & $\begin{array}{c}4 / 17 / 2003 \\
(\mathrm{mg} / \mathrm{L})\end{array}$ & $\begin{array}{c}10 / 7 / 2003 \\
(\mathrm{mg} / \mathrm{L})\end{array}$ & $\begin{array}{c}4 / 22 / 2003 \\
(\mathrm{mg} / \mathrm{L})\end{array}$ & $\begin{array}{c}10 / 7 / 2003 \\
(\mathrm{mg} / \mathrm{L})\end{array}$ & $(\mathrm{mg} / \mathrm{L})$ \\
\hline $\mathrm{pH}$ & $-^{\mathrm{d}}$ & $-^{\mathrm{d}}$ & 8.04 & 7.52 & 8.13 & 7.56 & $6.5-8.5$ \\
\hline TKN & - & - & $1.8 \mathrm{U}^{\mathrm{e}}$ & $1.0 \mathrm{U}$ & $1.8 \mathrm{U}$ & $1.0 \mathrm{U}$ & $\mathrm{NA}^{\mathrm{f}}$ \\
\hline $\mathrm{NO}_{3}-\mathrm{N}$ & - & - & 0.82 & 0.93 & 0.69 & 0.84 & 10 \\
\hline $\mathrm{NO}_{2}-\mathrm{N}$ & - & - & $0.10 \mathrm{U}$ & $0.10 \mathrm{U}$ & $0.10 \mathrm{U}$ & $0.10 \mathrm{U}$ & 1 \\
\hline Total Phosphorous & - & - & 0.043 & $0.10 \mathrm{U}$ & 0.074 & $0.10 \mathrm{U}$ & NA \\
\hline TDS & - & - & 407 & 554 & 404 & 412 & 500 \\
\hline Chloride & - & - & 91.4 & 213 & 66.8 & 112 & 250 \\
\hline Fluoride & - & - & 0.28 & 0.39 & 0.14 & 0.21 & 4 \\
\hline Aluminum & - & - & 0.707 & 0.251 & 0.0321 & 0.0591 & 0.2 \\
\hline Aluminum-filtered & - & - & $\mathrm{NT}^{\mathrm{g}}$ & $0.025 \mathrm{U}$ & NT & NT & 0.2 \\
\hline Arsenic & - & - & 0.0029 & $0.0025 \mathrm{U}$ & $0.0025 \mathrm{U}$ & $0.0025 \mathrm{U}$ & 0.05 \\
\hline Arsenic-filtered & - & - & NT & 0.0029 & NT & NT & 0.05 \\
\hline Cadmium & - & - & $0.001 \mathrm{U}$ & $0.001 \mathrm{U}$ & $0.001 \mathrm{U}$ & $0.001 \mathrm{U}$ & 0.005 \\
\hline Cadmium-filtered & - & - & NT & $0.001 \mathrm{U}$ & NT & NT & 0.005 \\
\hline Chromium & - & - & 0.0063 & 0.0075 & 0.0061 & 0.0066 & 0.1 \\
\hline Chromium-filtered & - & - & NT & 0.0063 & NT & NT & 0.1 \\
\hline
\end{tabular}


Table 3-4. (continued).

\begin{tabular}{|c|c|c|c|c|c|c|c|}
\hline \multirow{2}{*}{$\begin{array}{c}\text { Depth to Water } \\
\text { Table (ft) }\end{array}$} & \multicolumn{2}{|c|}{$\begin{array}{c}\text { ICPP-MON-V-191 } \\
\text { (GW-013008) }\end{array}$} & \multicolumn{2}{|c|}{$\begin{array}{c}\text { ICPP-MON-V-200 } \\
(\mathrm{GW}-013009)\end{array}$} & \multicolumn{2}{|c|}{$\begin{array}{c}\text { ICPP-MON-V-212 } \\
(\mathrm{GW}-013010)\end{array}$} & \multirow[t]{2}{*}{$\mathrm{PCS} / \mathrm{SCS}^{\mathrm{a}}$} \\
\hline & Dry $^{b}$ & Dry $^{\mathrm{b}}$ & 117.85 & 111.04 & 238.25 & 234.94 & \\
\hline $\begin{array}{l}\text { Sample Date } \\
\left(\text { units }^{c}\right)\end{array}$ & $\begin{array}{c}\text { April } 2003 \\
\text { Not Sampled }\end{array}$ & $\begin{array}{l}\text { October } 2003 \\
\text { Not Sampled }\end{array}$ & $\begin{array}{c}4 / 17 / 2003 \\
(\mathrm{mg} / \mathrm{L})\end{array}$ & $\begin{array}{c}10 / 7 / 2003 \\
(\mathrm{mg} / \mathrm{L})\end{array}$ & $\begin{array}{c}4 / 22 / 2003 \\
(\mathrm{mg} / \mathrm{L})\end{array}$ & $\begin{array}{c}10 / 7 / 2003 \\
(\mathrm{mg} / \mathrm{L})\end{array}$ & $(\mathrm{mg} / \mathrm{L})$ \\
\hline Copper & - & - & 0.0026 & 0.0029 & 0.001 & 0.001 & 1.3 \\
\hline Copper-filtered & - & - & NT & 0.0024 & NT & NT & 1.3 \\
\hline Iron & - & - & 1.240 & 0.355 & 0.0631 & 0.147 & 0.3 \\
\hline Iron-filtered & - & - & NT & 0.0566 & NT & NT & 0.3 \\
\hline Manganese & - & - & 0.0202 & 0.0054 & $0.0025 \mathrm{U}$ & $0.0025 \mathrm{U}$ & 0.05 \\
\hline Manganese-filtered & - & - & NT & $0.0025 \mathrm{U}$ & NT & NT & 0.05 \\
\hline Mercury & - & - & $0.0002 \mathrm{U}$ & $0.0002 \mathrm{U}$ & $0.0002 \mathrm{U}$ & $0.0002 \mathrm{U}$ & 0.002 \\
\hline Mercury-filtered & - & - & NT & $0.0002 \mathrm{U}$ & NT & NT & 0.002 \\
\hline Selenium & - & - & $0.0025 \mathrm{U}$ & $0.0025 \mathrm{U}$ & $0.0025 \mathrm{U}$ & $0.0025 \mathrm{U}$ & 0.05 \\
\hline Selenium-filtered & - & - & NT & $0.0025 \mathrm{U}$ & NT & NT & 0.05 \\
\hline Silver & - & - & $0.0025 \mathrm{U}$ & $0.0025 \mathrm{U}$ & $0.0025 \mathrm{U}$ & $0.0025 \mathrm{U}$ & 0.1 \\
\hline Silver-filtered & - & - & NT & $0.0025 \mathrm{U}$ & NT & NT & 0.1 \\
\hline Sodium & - & - & 47.10 & 134.0 & 11.40 & 21.2 & NA \\
\hline Sodium-filtered & - & - & NT & 133.0 & NT & NT & NA \\
\hline $\begin{array}{ll}\text { a. } & \text { Primary constituent s } \\
\text { b. } & \text { ICPP-MON-V-191 is } \\
\text { c. } & \text { The units for all para } \\
\text { d. } & \text { Since the well could } \\
\text { e. } & \text { U flag indicates that } \\
\text { f. } & \text { NA-Not applicable } \\
\text { g. } & \text { NT-No filtered met }\end{array}$ & $\begin{array}{l}\text { andards (PCS) and } \\
\text { a perched well and } \\
\text { heters listed are as } \\
\text { ot be sampled, no } \\
\text { he result was report } \\
1 \text { sample was taken }\end{array}$ & $\begin{array}{l}\text { secondary constitue } \\
\text { was dry in April } 20 \\
\text { hown, except for pl } \\
\text { nalyte-specific resu } \\
\text { ed as below the dete }\end{array}$ & $\begin{array}{l}\text { standards (SCS) } \\
\text { and October } 200 \\
\text { which is unitless. } \\
\text { are available. } \\
\text { on limit. }\end{array}$ & $\begin{array}{l}\text { roundwater refer } \\
\text { hen permit-requi }\end{array}$ & $\begin{array}{l}\text { ed in IDAPA } 58 \\
\text { sampling was pe }\end{array}$ & $\begin{array}{l}\text { 1.200.01.a and } b \\
\text { ned. Therefore, }\end{array}$ & ld not be sampled. \\
\hline
\end{tabular}


Table 3-5. Preoperational concentrations of TKN, aluminum, iron, and manganese in wells ICPP-MON-A-167 and ICPP-MON-A-166.

\begin{tabular}{|c|c|c|c|c|c|c|c|c|}
\hline & \multirow[b]{2}{*}{$\begin{array}{c}\text { November } \\
2000\end{array}$} & \multicolumn{3}{|c|}{ ICPP-MON-A-167 } & \multicolumn{4}{|c|}{ ICPP-MON-A-166 } \\
\hline & & $\begin{array}{c}\text { January } \\
2001 \\
\end{array}$ & $\begin{array}{c}\text { February } \\
2001\end{array}$ & $\begin{array}{c}\text { March } \\
2001 \\
\end{array}$ & $\begin{array}{c}\text { May } \\
2001^{\mathrm{a}}\end{array}$ & $\begin{array}{c}\text { March } \\
2001\end{array}$ & $\begin{array}{l}\text { May } \\
2001 \\
\end{array}$ & SCS \\
\hline TKN (mg/L) & $0.1 \mathrm{U}^{\mathrm{b}}$ & 0.141 & 0.143 & 0.705 & 0.315 & $0.1 \mathrm{U}$ & 0.240 & $\mathrm{NA}^{\mathrm{c}}$ \\
\hline Aluminum (mg/L) & 32.8 & 27.2 & 17.7 & 23.7 & 14.9 & 0.401 & 0.27 & 0.2 \\
\hline $\operatorname{Iron}(\mathrm{mg} / \mathrm{L})$ & 19.2 & 16.6 & 10.2 & 14.2 & 10.4 & 0.383 & 0.285 & 0.3 \\
\hline Manganese (mg/L) & 0.355 & 0.3 & 0.218 & 0.205 & 0.165 & 0.265 & 0.168 & 0.05 \\
\hline $\begin{array}{l}\text { a. Concentrations sl } \\
\text { b. U flag indicates t } \\
\text { c. NA-Not applica }\end{array}$ & $\begin{array}{l}\text { wn are the av } \\
\text { the result } w \\
\text { le. There is } n\end{array}$ & $\begin{array}{l}\text { rage of the } \\
\text { reported a } \\
\text { SCS. }\end{array}$ & $\begin{array}{l}\text { Imple and du } \\
\text { below the de }\end{array}$ & $\begin{array}{l}\text { icate sampl } \\
\text { ction limit. }\end{array}$ & collected i & May. & & \\
\hline
\end{tabular}

concentration, iron and manganese concentrations in April 2003 and October 2003 were approximately half of those in October 2002.

The April 2003 aluminum $(0.707 \mathrm{mg} / \mathrm{L})$, iron $(1.24 \mathrm{mg} / \mathrm{L})$, and manganese $(0.0202 \mathrm{mg} / \mathrm{L})$ concentrations in well ICPP-MON-V-200 showed a significant increase when compared to the October 2002 concentrations for aluminum $(0.137 \mathrm{mg} / \mathrm{L})$, iron $(0.213 \mathrm{mg} / \mathrm{L})$, and manganese $(0.0047 \mathrm{mg} / \mathrm{L})$. The concentrations for these parameters then showed a significant decrease in the October 2003 sample.

It is unlikely that the elevated levels of aluminum, iron, and manganese in the two aquifer wells and the perched well could be the result of the disposal of wastewater to the new ponds for the following reasons:

- Well ICPP-MON-A-167 was selected as the upgradient (background) monitoring well and should not be affected by discharges to the new ponds

- The concentrations of aluminum, iron, and manganese in the effluent since August 26, 2002, are considerably lower than the concentrations in the two-aquifer wells and the perched well

- Aluminum, iron, and manganese had been detected above their respective SCSs in the two aquifer wells in the preoperational samples.

One possible explanation for the elevated levels of aluminum, iron, and manganese may be that the wells were insufficiently developed during construction activities. Another possible explanation is that the annular seals were placed incorrectly, thus allowing bentonite slurry to affect the water quality. Prior to each sampling event, additional purging was performed on wells ICPP-MON-A-166, ICPP-MON-A-167, and ICPP-MON-V-200 to try to remove any residual slurry that may be in the wells as a result of the well construction activities. Even with the additional purging, the October 2003 samples from wells ICPP-MON-A-166 and ICPP-MON-A-167 were described in the sampling logbook as murky and gray in color and containing sediment. In contrast, the October samples from well ICPP-MON-V-200 were described as clear.

As discussed previously in this section, all permit-required samples are collected as unfiltered samples. However, during the October 2003 sampling event, an additional filtered (45 micron) sample 
was collected from wells ICPP-MON-A-166, ICPP-MON-A-167, and ICPP-MON-V-200, and was analyzed for metals. The aluminum, iron, and manganese concentrations in all three wells were significantly less in the filtered samples and were all below the applicable SCSs. Refer to Tables 3-3 and 3-4 for the filtered results. The filters were submitted for additional analysis to try to verify the source of the higher-than-expected aluminum, iron, and manganese concentrations in these three wells. Based on the filter results and further evaluation, corrective actions will be implemented as applicable.

The October 2002 total Kjeldahl nitrogen (TKN) results for wells ICPP-MON-A-166 and ICPP-MON-A-167 were higher than expected at $2.2 \mathrm{mg} / \mathrm{L}$. The reason for the higher-than-expected TKN concentrations in the October 2002 samples from wells ICPP-MON-A-166 and ICPP-MON-A-167 is unknown. However, the TKN concentrations in these two wells were lower in both April 2003 and October 2003. The TKN sample results for wells ICPP-MON-A-166 and ICPP-MON-A-167 were reported as undetected by the laboratory.

\subsection{Summary of Environmental Impacts}

During the 2003 permit year, daily and annual flow volumes to the New Percolation Ponds remained within limits established by the permit. The permit for the New Percolation Ponds does not specify concentration limits for the effluent to the ponds. However, in order to aid in monitoring plant efficiency, effluent concentrations were compared to the groundwater quality standards. During permit year 2003, when comparing the effluent concentrations to the groundwater quality standards as an indicator of plant efficiency, only total dissolved solids (TDS) and chloride fell above the standards (during 4 months of the permit year). However, because no permit limits are set for the effluent, these levels do not reflect permit noncompliances. During these same 4 months, the sodium concentrations in the effluent were also high. High concentrations of TDS, chloride, and sodium in the service waste effluent are usually indicative of a problem with the CPP-606 water treatment system. During the permit year, several evaluations were conducted in support of a project to upgrade the current INTEC water treatment system. These evaluations included a survey of the treated water demands, water quality requirements, and candidate conservation measures. Several design options to upgrade the water treatment system are currently being evaluated.

The October 2003 TDS sample result of $554 \mathrm{mg} / \mathrm{L}$ from well ICPP-MON-V-200 was above the SCS of $500 \mathrm{mg} / \mathrm{L}$. The TDS levels have increased since the first sample was collected in October 2002. Chloride and sodium concentrations have also increased in this well. The increased concentrations for these parameters can be attributed to the CPP-606 water treatment system and the application of this wastewater to the New Percolation Ponds.

The concentrations of aluminum and manganese in April 2003 and of aluminum, iron, and manganese in October 2003 in aquifer well ICPP-MON-A-166 were above the applicable permit limits. Aluminum and iron concentrations were also above the applicable permit limits in April 2003 and October 2003 in well ICPP-MON-V-200. The concentrations of aluminum, iron, and manganese in the background aquifer well (ICPP-MON-A-167) also exceeded the applicable groundwater quality standards in both April 2003 and October 2003. These elevated concentrations are not believed to be related to operational activities at the INTEC New Percolation Ponds. Concentrations of these parameters in the effluent are well below their applicable groundwater quality standards. One possible explanation may be that the wells were insufficiently developed during construction activities. Another possible explanation is that the annular seals were placed incorrectly, thus allowing bentonite slurry to affect the water quality. Prior to each sampling event, additional purging was performed on these wells to try to remove any residual slurry that may be in the wells as a result of the well construction activities. In addition, filtered samples were collected along with the permit-required unfiltered samples during the October 2003 sampling event for each of these wells. The filtered sample concentrations were below the groundwater 
quality standards and were significantly less than the concentrations in the unfiltered samples. The filters were submitted to the laboratory for additional analysis to try to verify the source of the aluminum, iron, and manganese in these wells. 


\section{IDAHO NUCLEAR TECHNOLOGY AND ENGINEERING CENTER SEWAGE TREATMENT PLANT DATA SUMMARY AND ASSESSMENT}

\subsection{System Description and Operation}

The Sewage Treatment Plant (STP) is east of INTEC, outside the INTEC security fence. The STP treats and disposes of sanitary and other related wastes at INTEC. Approximately 43 permanent buildings associated with INTEC are connected to the STP. The sewage system consists of six lift stations, each with two pumps (except CPP-1713, which has only one). Four of the lift stations (CPP-768, CPP-1713, CPP-1772, and CPP-724) pump the waste into one of the two main lift stations (CPP-728). This main lift station and the eastside main lift station (CPP-733) both contain a sewage grinder that the wastewater passes through before being pumped to the STP. The INTEC STP (Figure 4-1) consists of:

- $\quad$ Three aerated lagoons (Cell Nos. 1, 2, and 3)

- $\quad$ One quiescent, facultative stabilization lagoon (Cell No. 4)

- $\quad$ Four rapid infiltration (RI) trenches

- $\quad$ Six control stations (weir boxes) (CPP-769, CPP-770, CPP-771, CPP-772, CPP-773, and CPP-774).

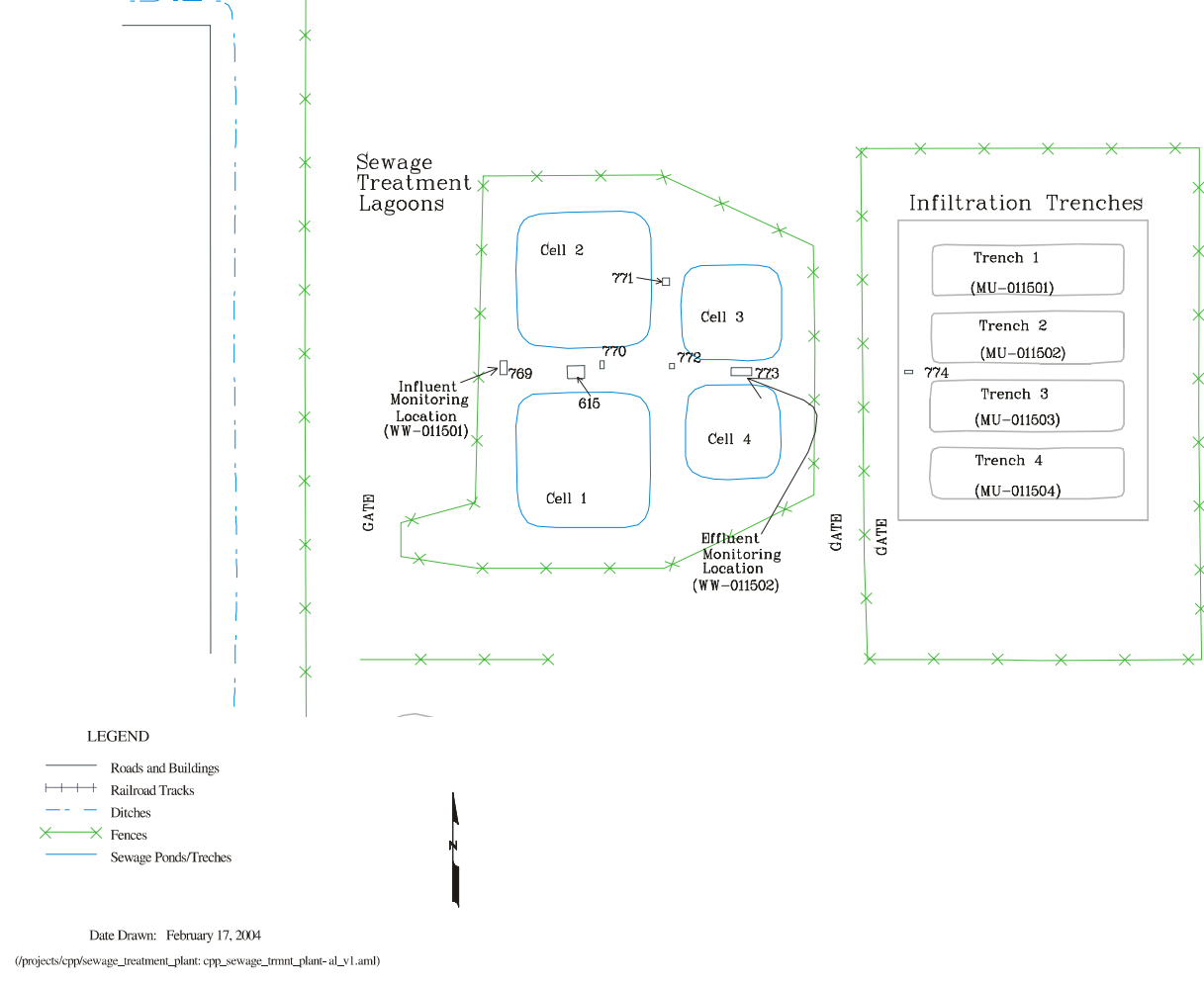

Figure 4-1. Idaho Nuclear Technology and Engineering Center Sewage Treatment Plant and rapid infiltration trenches. 
The six control stations direct the wastewater flow to the proper sequence of lagoons and infiltration trenches. Automatic flow-proportional composite samplers are located at control stations CPP-769 (influent) and CPP-773 (wastewater from the STP to the RI trenches). The composite samplers are connected to flow meters, thus allowing flow-proportional samples to be taken.

The influent wastewater is normally routed to aerated lagoon Cell No. 1. The wastewater then passes from Cell No. 1 through control station CPP-770 to aerated lagoon Cell No. 2. From Cell No. 2, all flow is divided in control station CPP-771, where half goes to aerated Cell No. 3 and the other half to quiescent facultative lagoon Cell No. 4. The INTEC STP depends on natural biological and physical processes (digestion, oxidation, photosynthesis, respiration, aeration, and evaporation) to treat the wastewater.

The STP was originally designed to treat a flow of 80,000 gallons per day (gpd). However, the average daily influent flow for reporting year 2003 was approximately 45,000 gpd. Lagoon Cell Nos. 1 and 2 each have a retention time of 11 days at the designed flow of 80,000 gpd and 22 days at 40,000 gpd. Lagoon Cell Nos. 3 and 4 each has a designed retention time of 4.5 days at the maximum flow of 80,000 gpd to each cell. Because the flow splits, with half the flow going to each cell, the calculated retention time for each cell based on a flow of $40,000 \mathrm{gpd}$ is approximately 18 days.

As discussed in more detail in Section 4.2, the additional aeration from operating both blowers in Cell Nos. 1 and 2 and the surface aerators in Cell No. 3 was expected to increase the removal of ammonia from the wastewater. Ammonia is removed primarily through the process of air stripping and thereby, reduces the concentration of total nitrogen in the effluent.

The liner in Cell No. 1 had inflated around the edges of the cell above the water level. To determine whether the liner was leaking, a seepage test was performed on Cell No. 1. The seepage test was performed in accordance with the "State of Idaho Procedure for Evaluating Wastewater Treatment Lagoon Seepage Rates" (DEQ 2002b). The test began on September 2, 2003, and was completed on September 18, 2003. It was concluded that there was no seepage loss during the testing period.

It is suspected that air is escaping from a hole in an aeration pipe under the liner, thus causing the liner to inflate around the edges. When the blowers are turned off, the liner deflates. The cause of the inflated liner is being evaluated and corrective actions are expected to be implemented in 2004.

\subsection{Status of Special Compliance Conditions}

In accordance with the permit, the INTEC STP was required to meet the total nitrogen limit of $20 \mathrm{mg} / \mathrm{L}$ measured at the influent to the RI trenches (CPP-773, effluent) within 2 years of permit issuance or submit a preliminary engineering report outlining modifications that would bring the STP into compliance. Because the total nitrogen had not exceeded $20 \mathrm{mg} / \mathrm{L}$ since permit issuance (September 20, 1995), it was agreed during a conference call on April 1, 1997, between DEQ and the INEEL that an approved engineering plan was not required. However, in December of 1997, the total nitrogen limit was exceeded for the first time. Due to this and several subsequent exceedences, an engineering study and a corrective action plan were submitted to DEQ on November 11, 1998 (Graham 1998).

The majority of corrective actions identified in the corrective action plan were completed prior to the start of the 2002 permit year. The Shear Gate Replacement Project, a corrective action identified in the 1998 corrective action plan, was completed in 2002. The as-built drawings were submitted to DEQ on December 17, 2002, (Guymon 2002b) and approved by DEQ on December 23, 2002 (Teuscher 2002). The intent of the Shear Gate Replacement Project was to bring the existing STP up to maximum treatment capability by preventing water from bypassing the treatment system and increasing retention time. 
In addition to the corrective actions identified in the corrective action plan, the effects of additional aeration to strip ammonia from the wastewater were evaluated. The simultaneous operation of two blowers, providing increased aeration to lagoon Cell Nos. 1 and 2, and the installation and operation of two surface aerators in lagoon Cell No. 3 were tested. Section 4.3.1 discusses the removal of nitrogen in the STP lagoons.

The effects of the corrective actions and the additional aeration were evaluated. As discussed in last year's report, it was determined that the implementation of the corrective actions and increased aeration would not ensure that the effluent would remain below the permit limit of $20 \mathrm{mg} / \mathrm{L}$ for total nitrogen. Subsequently, the engineering evaluations conducted over the past several years were comprehensively reviewed. A preferred alternative for maintaining the total nitrogen in the effluent below $20 \mathrm{mg} / \mathrm{L}$ was selected in this review. The preferred alternative is to combine the INTEC STP and the INTEC Service Waste System effluent streams into a single effluent stream. This combined effluent stream would then be discharged to the INTEC New Percolation Ponds.

The following activities in support of the preferred alternative have occurred:

- January 28, 2003-Proposal to combine the INTEC STP effluent with the INTEC Service Waste System effluent was submitted to DEQ. The proposal contained a discussion of potential impacts the proposed alternative would have on nutrient and chemical constituent concentrations

(Guymon 2003e).

- $\quad$ March 6, 2003-Meeting with DEQ, NE-ID, and BBWI personnel to discuss combining the INTEC STP effluent and the INTEC Service Waste System effluent.

- $\quad$ April 14, 2003-Letter from DEQ stating that "combining the waste streams is acceptable through a major modification of WLAP LA-000130-03" (Rackow 2003c). The DEQ requested the INEEL to submit a request for a major modification and submit preliminary plans and specifications for review and approval prior to issuance of the permit modification.

- June 26, 2003 - The request for a major modification to WLAP LA-000130-03 was submitted to DEQ (Guymon 2003b).

- $\quad$ September 25, 2003-A meeting was held between DEQ and BBWI personnel to discuss DEQ's comments concerning the plans and specifications (previously submitted) for the proposed project to combine the two effluent streams. BBWI personnel committed to revise and resubmit the plans and specifications based on DEQ's comments.

\subsection{Influent and Effluent Monitoring Results}

The permit sets effluent (CPP-773, wastewater from the STP to the RI trenches) limits for total nitrogen (TKN $+\mathrm{NNN})$ and total suspended solids (TSS) and requires that the influent and effluent be sampled and analyzed monthly for several parameters. Influent samples were collected from control station CPP-769, and effluent samples were collected from control station CPP-773. The samples were analyzed for the parameters required by Schedule B of the permit. The permit-required data are summarized in Tables 4-1 and 4-2. Except for the monthly total coliform grab sample, all samples are to be collected as 24-hour flow-proportional composites. All permit-required samples were collected as scheduled. 
Table 4-1. Idaho Nuclear Technology and Engineering Center Sewage Treatment Plant influent data (WW-011501).

\begin{tabular}{lcccccc}
\hline \multicolumn{1}{c}{ Sample Month } & Sample Date & $\begin{array}{c}\mathrm{TKN} \\
(\mathrm{mg} / \mathrm{L})\end{array}$ & $\begin{array}{c}\mathrm{NNN}^{\mathrm{a}} \\
(\mathrm{mg} / \mathrm{L})\end{array}$ & $\begin{array}{c}\text { Total } \\
\text { Phosphoru } \\
(\mathrm{mg} / \mathrm{L})\end{array}$ & $\begin{array}{c}\mathrm{TSS} \\
(\mathrm{mg} / \mathrm{L})\end{array}$ & $\begin{array}{c}\text { BOD } \\
(\mathrm{mg} / \mathrm{L})\end{array}$ \\
\hline November & $11 / 20 / 2002$ & 27.2 & 0.096 & 3.75 & 228.0 & 81.0 \\
December & $12 / 3 / 2002$ & 36.2 & 0.209 & 5.05 & 260.0 & 137.0 \\
January & $1 / 29 / 2003$ & 29.2 & 0.302 & 5.87 & 236.0 & 169.0 \\
February & $2 / 19 / 2003$ & 48.5 & 0.365 & 5.12 & 132.0 & 137.0 \\
March & $3 / 25 / 2003$ & 36.4 & 0.309 & 5.79 & 133.0 & 135.0 \\
April & $4 / 16 / 2003$ & 36.8 & 0.245 & 5.35 & 195.0 & 180.0 \\
May & $5 / 15 / 2003$ & 68.0 & 0.144 & 8.79 & 280.0 & 365.0 \\
June & $6 / 11 / 2003$ & 46.5 & 0.210 & 6.92 & 163.0 & 879.0 \\
July & $7 / 8 / 2003$ & $65.2^{\mathrm{b}}$ & $0.072^{\mathrm{b}}$ & $6.37^{\mathrm{b}}$ & $73.7^{\mathrm{b}}$ & $121.5^{\mathrm{b}}$ \\
August & $8 / 14 / 2003$ & 52.9 & 0.133 & 5.83 & 175.0 & 255.0 \\
September & $9 / 3 / 2003$ & 41.9 & 0.073 & 6.32 & 164.0 & 162.0 \\
October & $10 / 1 / 2003$ & 73.4 & 0.156 & 10.40 & 388.0 & 534.0 \\
Yearly Average ${ }^{\mathrm{c}}$ & & 46.9 & 0.193 & 6.30 & 202.3 & 263.0 \\
\hline a. NNN—Nitrate + nitrite as nitrogen. & & & & & \\
b. The result shown is a monthly average of duplicate samples taken for the month. & & & \\
c. Yearly average is determined from the average of the monthly values. &
\end{tabular}

With the exception of the December 2002 TSS sample result of $107 \mathrm{mg} / \mathrm{L}$ (Guymon 2003f), monthly average effluent TSS concentrations remained below the limit of $100 \mathrm{mg} / \mathrm{L}$, with an annual average of $37.5 \mathrm{mg} / \mathrm{L}$. During the 2003 permit year, the average monthly total nitrogen exceeded the monthly average limit of $20 \mathrm{mg} / \mathrm{L}$ during March (Guymon 2003g). Typically, the highest nitrogen concentrations occur during the colder months. The nitrogen results are discussed further in Section 4.3.1.

Yearly average concentrations were above the 2002 reported yearly averages for all influent permit-required parameters, except for nitrate + nitrite as nitrogen. The June 2003 concentration $(879 \mathrm{mg} / \mathrm{L})$ represents the historical high for 5-day biological oxygen demand (BOD). For the effluent, yearly average concentrations were above the 2002 reported yearly averages for all permit-required parameters, except for nitrate + nitrite as nitrogen, electrical conductivity, and total coliform. With the exception of BOD and TDS, all permit-required parameters were within the range of concentrations reported in past years. The June 2003 BOD concentration $(387 \mathrm{mg} / \mathrm{L})$ and the October 2003 TDS concentration $(873 \mathrm{mg} / \mathrm{L})$ represented historical high concentrations for the effluent.

Table 4-3 summarizes calculated removal efficiencies (REs) for total nitrogen, BOD, and TSS. As in previous years, in general, BOD and TSS continue to be treated more efficiently than total nitrogen by the INTEC STP, with yearly average REs of $85 \%$ for BOD, $76 \%$ for TSS, and $64 \%$ for total nitrogen. 
Table 4-2. Idaho Nuclear Technology and Engineering Center Sewage Treatment Plant effluent data (WW-011502).

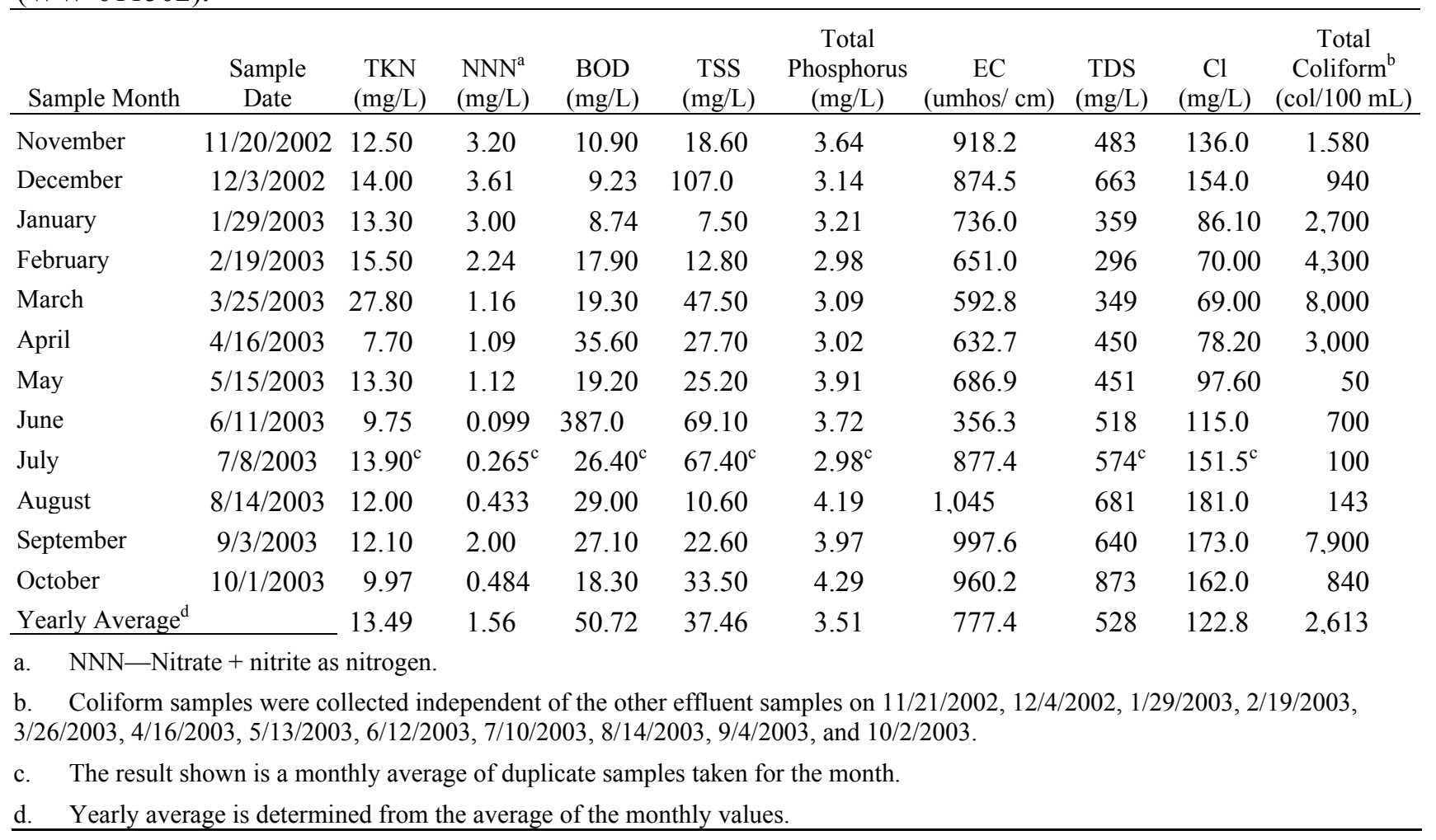

\subsubsection{Wastewater Nitrogen Concentrations}

As discussed in the 2002 WLAP report (INEEL 2003a), it had been determined through sampling and analysis that the majority of total nitrogen in the wastewater entering the STP (CPP-769) is in the form of ammonia. It had also been determined that the majority of ammonia is being removed in lagoon Cell Nos. 1 and 2 through the process of air stripping.

Two blowers are available to aerate lagoon Cell Nos. 1 and 2. Normal operation had been to operate one blower at a time. However, in an effort to remove additional ammonia, both blowers were put into operation in mid-June of 2000. Operating both blowers approximately doubles the airflow rate to Cell Nos. 1 and 2. Winter conditions (i.e., ice formation on pond Cell No. 2) can prevent the operation of the two blowers. For the 2003 permit year, blower operation was as follows:

- November 1, 2002, through December 1, 2002, both blowers were in operation.

- December 2, 2002, through February 18, 2003, only one blower was in operation.

- $\quad$ February 19, 2003, through August 25, 2003, both blowers were in operation.

- August 26, 2003, through September 18, 2003, only one blower was in operation. During this period, a seepage test was being performed on Cell No. 1 and aeration was shut off to this cell.

- $\quad$ September 19, 2003, through October 31, 2003, both blowers were in operation. 
Table 4-3. Removal efficiency ${ }^{\mathrm{a}}$ for permit monitoring parameters at the Idaho Nuclear Technology and Engineering Center Sewage Treatment Plant.

\begin{tabular}{lccc}
\hline \multicolumn{1}{c}{ Sample Month } & $\begin{array}{c}\text { Total Nitrogen } \\
(\%)\end{array}$ & $\begin{array}{c}\text { BOD } \\
(\%)\end{array}$ & $\begin{array}{c}\text { TSS } \\
(\%)\end{array}$ \\
\hline November 2002 & 42 & 87 & 92 \\
December 2002 & 52 & 93 & 59 \\
January 2003 & 45 & 95 & 97 \\
February 2003 & 64 & 87 & 90 \\
March 2003 & 21 & 86 & 64 \\
April 2003 & 76 & 80 & 86 \\
May 2003 & 79 & 95 & 91 \\
June 2003 & 79 & 56 & 58 \\
July 2003 & 78 & 78 & 9 \\
August 2003 & 77 & 89 & 94 \\
September 2003 & 66 & 83 & 86 \\
October 2003 & 86 & 97 & 91 \\
Yearly Average RE & 64 & 85 & 76 \\
\hline a. Removal efficiency (RE) $=[($ average monthly influent concentration - average monthly effluent concentration $) \div$ average \\
monthly influent concentration)] $\times 100$. \\
b. Total nitrogen includes NNN and TKN.
\end{tabular}

In addition to operating the two blowers, two 5-horsepower surface aerators were installed in lagoon Cell No. 3 on April 26, 2001, and placed into operation on June 4, 2001. No aerators were installed in lagoon Cell No. 4. For the 2003 permit year, only one surface aerator in lagoon Cell No. 3 operated from November 1, 2002, through March 17, 2003. From March 18, 2003, through the end of the permit year, both aerators operated.

A study was performed to determine whether increasing aeration would be an effective method for maintaining effluent total nitrogen levels below the permit limit of $20 \mathrm{mg} / \mathrm{L}$ (INEEL 2002). The aeration study found that surface aeration in lagoon Cell No. 3 worked well during the summer but not the winter. Total nitrogen in the effluent typically increases during the winter months when the cold temperatures decrease removal efficiencies. The study concluded that using aeration to remove ammonia nitrogen from the wastewater would not guarantee the total nitrogen concentration in the effluent would remain below the permit limit of $20 \mathrm{mg} / \mathrm{L}$.

As shown in Figure 4-2, the total nitrogen concentration in the effluent (CPP-773) exceeded the permit limit in March 2003. 


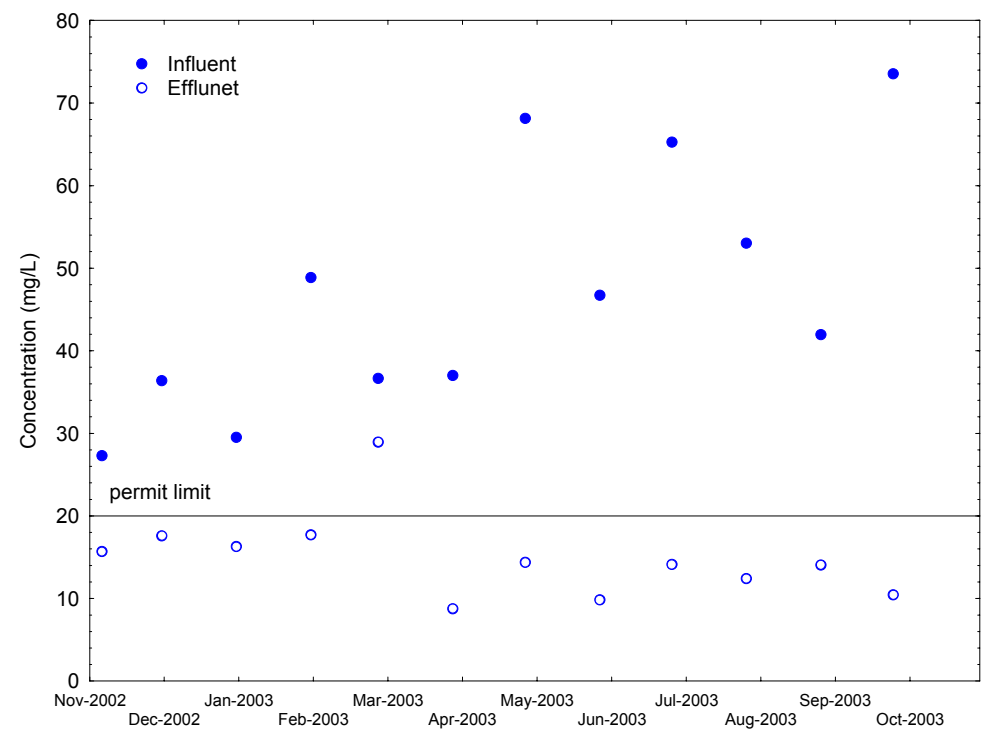

Figure 4-2. Idaho Nuclear Technology and Engineering Center Sewage Treatment Plant influent (CPP-769) and effluent (CPP-773) total nitrogen concentrations.

\subsubsection{Flow Volumes}

Influent flow is measured by two ultrasonic, dual transducer, clamp-on-design flow meters attached to the force main lines coming from final lift stations CPP-728 and CPP-733. These flow meters are located just prior to the CPP-769 (influent to the STP) control structure. The effluent (CPP-773, wastewater from the STP to the RI trenches) flow meter consists of an ultrasonic level sensor and a V-notch weir plate. The two influent flow meters and the effluent flow meter provide continuous flow data. However, the point of compliance is the effluent flow measurement. Daily flow readings are taken and recorded in gpd. Table 4-4 summarizes monthly and total flow volume, and Appendix $\mathrm{C}$ presents daily flow readings and copies of the required electronic WLAP data files (DEQ 2002a).

Beginning March 17, 1997, the rotation frequency of the infiltration trenches was changed from 2 weeks to 1 week. This increased rotation frequency allowed greater soil wetting and drying in an effort to maximize nitrogen removal. Table 4-5 summarizes the monthly flow to each trench. The 1-week rotation frequency was maintained during the 2003 permit year, even during periods of no flow.

Total annual effluent flow to the trenches (measured by the flow meters) was $7.53 \mathrm{MG}$ during the 2003 permit year, which is well below the permit limit of $30 \mathrm{MG} /$ year. During 1997, a disparity between the measured influent and effluent values was identified. Since 1997 (as documented in past annual reports), engineering studies, corrective actions, and flow studies have been performed to address the disparity. During the 2003 permit year, several discrepancies were identified with both influent and effluent flow measurements:

- $\quad$ The accuracy of the influent flow reading is suspect from November 1, 2002, through February 12, 2003, due to the south influent flow meter being out of service (OOS) during this period

- $\quad$ No influent reading was taken on December 13, 2002

- $\quad$ Effluent meter readings from March 29, 2003, through May 21, 2003, are suspect due to a leaking weir plate discharge valve 
Table 4-4. Idaho Nuclear Technology and Engineering Center Sewage Treatment Plant flow summaries.

\begin{tabular}{|c|c|c|c|c|c|c|c|c|}
\hline \multirow[b]{2}{*}{$\begin{array}{l}\text { Sample } \\
\text { Month }\end{array}$} & \multicolumn{4}{|c|}{ Influent (WW-011501) ${ }^{\mathrm{a}}$} & \multicolumn{4}{|c|}{ Effluent (WW-011502) } \\
\hline & $\begin{array}{c}\text { Average } \\
\left(\mathrm{gpd}^{\mathrm{c}}\right)\end{array}$ & $\begin{array}{l}\text { Minimum } \\
(\mathrm{gpd})\end{array}$ & $\begin{array}{l}\operatorname{Maximum}^{\mathrm{b}} \\
(\mathrm{gpd})\end{array}$ & $\begin{array}{l}\text { Total } \\
\left(\mathrm{MG}^{\mathrm{d}}\right)\end{array}$ & $\begin{array}{l}\text { Average } \\
\text { (gpd) }\end{array}$ & $\begin{array}{l}\text { Minimum } \\
(\text { gpd })\end{array}$ & $\begin{array}{l}\text { Maximum } \\
\text { (gpd) }\end{array}$ & $\begin{array}{l}\text { Total } \\
\left(\mathrm{MG}^{\mathrm{d}}\right)\end{array}$ \\
\hline November 2002 & 43,849 & 3,430 & 57,647 & 1.32 & 33,110 & 11,810 & 48,583 & 0.99 \\
\hline December 2002 & 42,267 & 20,688 & 77,914 & 1.27 & 33,294 & 20,800 & 48,182 & 1.03 \\
\hline January 2003 & 37,257 & 18,106 & 53,140 & 1.16 & 26,260 & 13,955 & 39,893 & 0.81 \\
\hline February 2003 & 45,132 & 24,058 & 62,144 & 1.26 & 23,834 & 10,949 & 36,633 & 0.67 \\
\hline March 2003 & 47,279 & 27,114 & 62,927 & 1.47 & 13,493 & 328 & 23,362 & 0.42 \\
\hline April 2003 & 40,012 & 14,239 & 58,945 & 1.00 & 6,289 & 18 & 18,951 & 0.18 \\
\hline May 2003 & 35,375 & 14,074 & 61,415 & 0.99 & 5,324 & 31 & 22,350 & 0.15 \\
\hline June 2003 & 47,211 & 28,499 & 79,739 & 1.42 & 16,009 & 2,553 & 32,204 & 0.48 \\
\hline July 2003 & 48,778 & 26,900 & 69,611 & 1.51 & 17,930 & 1,010 & 36,658 & 0.56 \\
\hline August 2003 & 51,770 & 38,297 & 67,747 & 1.35 & 27,284 & 10,012 & 43,815 & 0.74 \\
\hline September 2003 & 42,417 & 18,368 & 62,980 & 1.27 & 21,777 & 4,829 & 46,954 & 0.65 \\
\hline October 2003 & 54,973 & 35,662 & 83,072 & 1.32 & 27,083 & 5,462 & 41,881 & 0.84 \\
\hline Yearly Summary & 44,693 & 3,430 & 83,072 & 15.34 & 20,974 & 18 & 48,583 & 7.52 \\
\hline \multicolumn{9}{|c|}{$\begin{array}{l}\text { a. The accuracy of the influent flow reading is suspect from November } 1,2002 \text {, through February } 12,2003 \text {, due to the south influent flow } \\
\text { meter being out of service (OOS) during this period. No influent reading was taken on December } 13,2002 \text {. Effluent meter readings from } \\
\text { March } 29,2003 \text {, through May } 21,2003 \text { are suspect due to a leaking weir plate discharge valve. No influent reading was taken on April } 23 \text {, } \\
2003 \text {, due to work being performed on the new power supply. No influent readings were available from May } 24,2003 \text {, through May } 26 \text {, } \\
2003 \text {, due to the readings being taken incorrectly. Due to power outages, the influent flow meters were OOS from April } 11,2003 \text {, through } \\
\text { April } 14,2003 \text {, from August } 2,2003 \text {, through August } 6,2003 \text {, and from October } 3,2003 \text {, through October } 9,2003 \text {; and the effluent flow } \\
\text { meters were OOS from August } 2,2003 \text {, through August } 5,2003 \text {, and from October } 3,2003 \text {, through October } 8,2003 \text {. }\end{array}$} \\
\hline \multirow{2}{*}{\multicolumn{9}{|c|}{$\begin{array}{l}\text { b. Values shown for the month are based on days when the flow meters were operational. } \\
\text { c. gpd-Gallons per day. }\end{array}$}} \\
\hline & & & & & & & & \\
\hline \multicolumn{9}{|c|}{ d. Monthly and annual permit totals are shown in million gallons (MG). } \\
\hline
\end{tabular}

- $\quad$ No influent reading was taken on April 23, 2003, due to work being performed on the new power supply

- $\quad$ No influent readings were available from May 24, 2003, through May 26, 2003, due to the readings being taken incorrectly

- $\quad$ Due to power outages, the influent flow meters were OOS from April 11, 2003, through April 14, 2003; from August 2, 2003, through August 6, 2003; and from October 3, 2003, through October 9, 2003; and the effluent flow meters were OOS from August 2, 2003, through August 5, 2003; and from October 3, 2003, through October 8, 2003.

For each of these discrepancies, average daily flows were estimated based on historical flow data and assumed worst-case scenarios. Using these estimated average daily flows, the total annual effluent flow is estimated to be $8.95 \mathrm{MG}$. While this is above the total annual flow reported by the flow meters (7.53 MG), it is well below the permit limit (30 MG). 
Table 4-5. Monthly flow to each trench.

\begin{tabular}{lcccc}
\hline $\begin{array}{c}\text { Sample } \\
\text { Month }\end{array}$ & $\begin{array}{c}\text { Trench 1 } \\
(\text { MU-011501) } \\
(\text { MG) }\end{array}$ & $\begin{array}{c}\text { Trench 2 } \\
(\text { MU-011502) } \\
(\text { MG) }\end{array}$ & $\begin{array}{c}\text { Trench 3 } \\
(\text { MU-011503) } \\
(\text { MG })\end{array}$ & $\begin{array}{c}\text { Trench 4 } \\
\text { (MU-011504) } \\
(\text { MG) }\end{array}$ \\
\hline November 2002 & 0.210 & 0.223 & 0.285 & 0.276 \\
December 2002 & 0.261 & 0.277 & 0.238 & 0.257 \\
January 2003 & 0.219 & 0.165 & 0.165 & 0.266 \\
February 2003 & 0.160 & 0.191 & 0.171 & 0.145 \\
March 2003 & 0.127 & 0.135 & 0.071 & 0.085 \\
April 2003 & 0.069 & 0.032 & 0.061 & 0.021 \\
May 2003 & 0.081 & 0.010 & 0.031 & 0.033 \\
June 2003 & 0.152 & 0.105 & 0.112 & 0.110 \\
July 2003 & 0.142 & 0.213 & 0.109 & 0.091 \\
August 2003 & 0.189 & 0.248 & 0.117 & 0.182 \\
September 2003 & 0.133 & 0.123 & 0.228 & 0.169 \\
October 2003 & 0.175 & 0.201 & 0.289 & 0.175 \\
Yearly Total & 1.918 & 1.923 & 1.877 & 1.810 \\
\hline a. Trench totals are in million gallons (MG). & & & \\
\hline
\end{tabular}

\subsection{Evaluation of Groundwater Data}

To measure potential STP impacts to groundwater, the permit requires that groundwater samples be collected from three monitoring wells (see Figure 4-3):

- $\quad$ One background aquifer well (USGS-121) upgradient of INTEC

- $\quad$ One perched water well (ICPP-MON-PW-024) immediately adjacent to the STP

- $\quad$ One aquifer well (USGS-052) downgradient of the STP, which serves as the point of compliance.

Sampling must be conducted semiannually (April and October) and must include a list of specified parameters for analysis. Contaminant concentrations in USGS-052 are limited by primary constituent standards (PCS) and secondary constituent standards (SCS) specified in IDAPA 58.01.11, "Ground Water Quality Rule.” All permit-required samples are collected as unfiltered samples.

During the 2003 permit year, groundwater samples were collected in April and October. Duplicate samples were collected from USGS-052 in April and October. Table 4-6 shows the water levels (collected prior to purging and sampling) and analytical results for all parameters required by the permit. Groundwater samples collected from USGS-052 were in compliance with all permit limits during 2003. Chloride and nitrate concentrations in USGS-052 were elevated compared to USGS-121, as in previous years. 


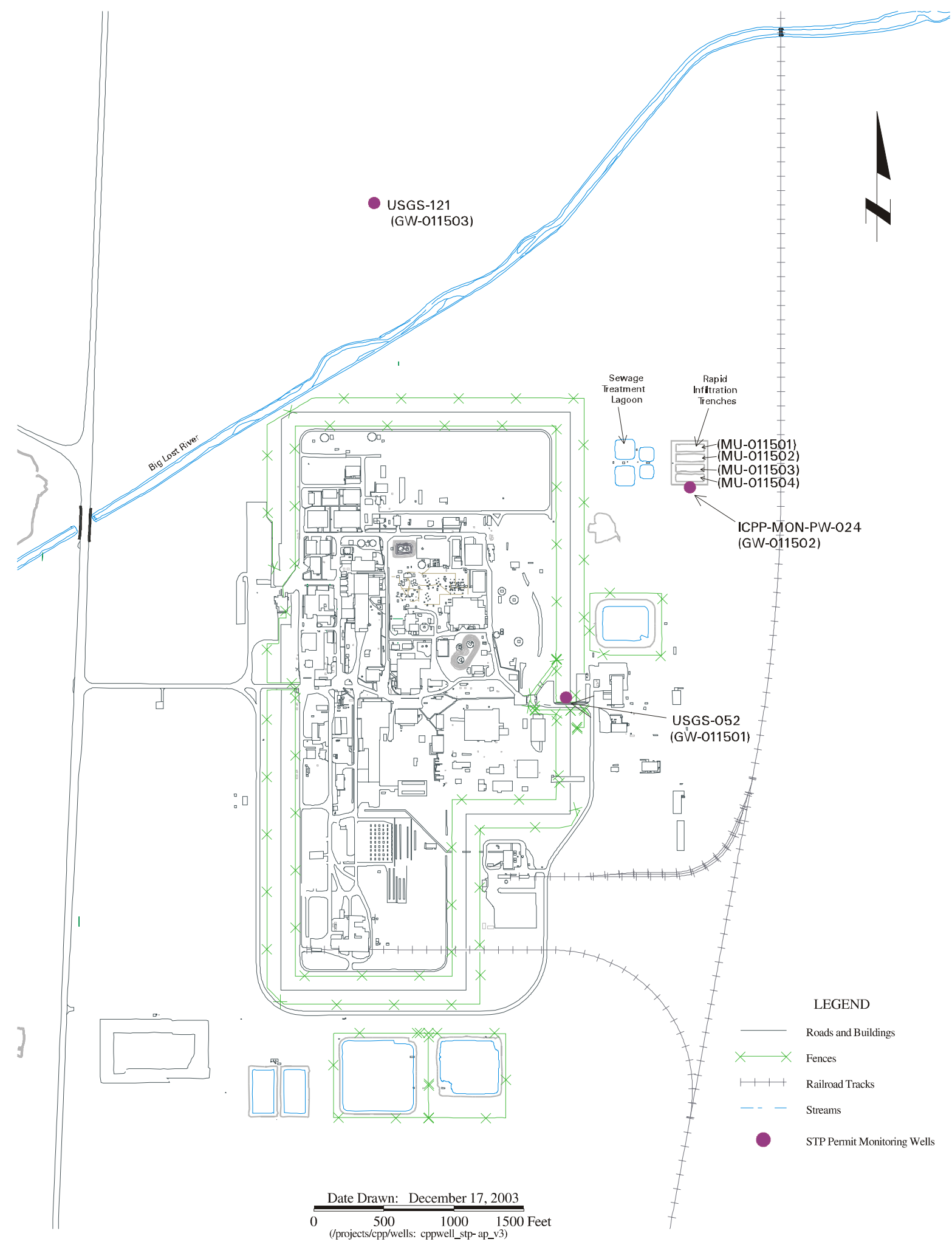

Figure 4-3. Locations of Idaho Nuclear Technology and Engineering Center Sewage Treatment Plant WLAP monitoring wells. 
Table 4-6. Idaho Nuclear Technology and Engineering Center Sewage Treatment Plant groundwater data for April and October 2003.

\begin{tabular}{|c|c|c|c|c|c|c|c|c|c|}
\hline \multirow{2}{*}{$\begin{array}{l}\text { Depth to Water } \\
\text { Table (ft) }\end{array}$} & \multicolumn{2}{|c|}{$\begin{array}{l}\text { ICPP-MON-PW-024 } \\
\quad(\mathrm{GW}-011502)\end{array}$} & \multicolumn{4}{|c|}{$\begin{array}{c}\text { USGS-52 } \\
(\mathrm{GW}-011501)\end{array}$} & \multicolumn{2}{|c|}{$\begin{array}{c}\text { USGS-121 } \\
(\mathrm{GW}-011503)\end{array}$} & \multirow[t]{2}{*}{$\mathrm{PCS} / \mathrm{SCS}^{\mathrm{a}}$} \\
\hline & 61.55 & 63.8 & 457.26 & 457.26 & 459.32 & 459.32 & 460.92 & 460.94 & \\
\hline $\begin{array}{l}\text { Sample Date } \\
\text { (units) }\end{array}$ & $\begin{array}{c}4 / 15 / 2003 \\
(\mathrm{mg} / \mathrm{L}) \\
\end{array}$ & $\begin{array}{c}10 / 8 / 2003 \\
(\mathrm{mg} / \mathrm{L}) \\
\end{array}$ & $\begin{array}{c}4 / 14 / 2003 \\
(\mathrm{mg} / \mathrm{L})\end{array}$ & $\begin{array}{c}4 / 14 / 2003^{\mathrm{b}} \\
(\mathrm{mg} / \mathrm{L})\end{array}$ & $\begin{array}{c}10 / 21 / 2003 \\
(\mathrm{mg} / \mathrm{L})\end{array}$ & $\begin{array}{c}10 / 21 / 2003^{b} \\
(\mathrm{mg} / \mathrm{L})\end{array}$ & $\begin{array}{c}4 / 15 / 2003 \\
(\mathrm{mg} / \mathrm{L}) \\
\end{array}$ & $\begin{array}{c}10 / 8 / 2003 \\
(\mathrm{mg} / \mathrm{L})\end{array}$ & $(\mathrm{mg} / \mathrm{L})$ \\
\hline $\mathrm{TKN}$ & $0.90 \mathrm{U}^{\mathrm{c}}$ & $1.0 \mathrm{U}$ & $0.90 \mathrm{U}$ & $0.90 \mathrm{U}$ & $1.0 \mathrm{U}$ & $1.0 \mathrm{U}$ & $0.90 \mathrm{U}$ & $1.0 \mathrm{U}$ & $\mathrm{NA}^{\mathrm{d}}$ \\
\hline Chloride & 91.0 & 139 & 31.3 & 31.5 & 25.8 & 25.8 & 12.2 & 12.0 & 250 \\
\hline TDS & 422 & 569 & 261 & 214 & 254 & 257 & 178 & 219 & 500 \\
\hline $\mathrm{NO}_{3}-\mathrm{N}$ & 10.8 & 5.8 & 3.7 & 3.7 & 2.7 & 2.6 & 0.70 & 0.70 & 10 \\
\hline $\mathrm{NO}_{2}-\mathrm{N}$ & $0.10 \mathrm{U}$ & $0.10 \mathrm{U}$ & $0.10 \mathrm{U}$ & $0.10 \mathrm{U}$ & $0.10 \mathrm{U}$ & $0.10 \mathrm{U}$ & $0.10 \mathrm{U}$ & $0.10 \mathrm{U}$ & 1 \\
\hline $\mathrm{NH}_{4}-\mathrm{N}$ & $0.10 \mathrm{U}$ & $0.10 \mathrm{U}$ & $0.10 \mathrm{U}$ & $0.10 \mathrm{U}$ & $0.10 \mathrm{U}$ & $0.10 \mathrm{U}$ & $0.10 \mathrm{U}$ & $0.10 \mathrm{U}$ & NA \\
\hline BOD & 3.8 & $2.0 \mathrm{U}$ & 2.5 & 2.8 & $2.0 \mathrm{U}$ & $2.0 \mathrm{U}$ & 3.0 & $2.0 \mathrm{U}$ & NA \\
\hline Total Phosphorous & 2.1 & 2.4 & 0.068 & 0.085 & $0.10 \mathrm{U}$ & $0.10 \mathrm{U}$ & 0.077 & $0.10 \mathrm{U}$ & NA \\
\hline Total Coliform & Absent & $500^{\mathrm{e}}$ & Absent & Absent & Absent & Absent & Absent & Absent & $1 \mathrm{col} / 100 \mathrm{~mL}$ \\
\hline Fecal Coliform & Absent & $2^{f}$ & Absent & Absent & Absent & Absent & Absent & Absent & NA \\
\hline $\begin{array}{l}\text { a. Primary constituent } \\
\text { b. Duplicate sample. } \\
\text { c. U flag indicates tha } \\
\text { d. NA- not applicabl } \\
\text { e. Klebsiella ozanae v } \\
\text { f. Klebsiella ozanae a }\end{array}$ & $\begin{array}{l}\text { tandards (PCS) } \\
\text { the result was } \mathrm{r} \\
\text { is speciated in } \mathrm{t} \\
\text { d Escherichia c }\end{array}$ & $\begin{array}{l}\text { id secondary c } \\
\text { orted as below } \\
\text { sample. } \\
\text { were speciate }\end{array}$ & $\begin{array}{l}\text { tituent standarc } \\
\text { detection limi } \\
\text { a this sample. }\end{array}$ & (SCS) in groun & water reference & d in IDAPA 58.0 & $.11 .200 .01 . \mathrm{a}$ an & & \\
\hline
\end{tabular}


Monitoring well ICPP-MON-PW-024 was constructed in the perched water zone approximately $70 \mathrm{ft}$ below the surface of the infiltration trenches. It is used as an indicator of treatment efficiency of the soil rather than serving as a point of compliance. As in previous years, TDS and chloride concentrations in ICPP-MON-PW-024 approximated those of the effluent. For permit year 2003, the TDS concentration in well ICPP-MON-A-024 increased from $422 \mathrm{mg} / \mathrm{L}$ in the April sample to $569 \mathrm{mg} / \mathrm{L}$ in the October sample. The October result was above the SCS of $500 \mathrm{mg} / \mathrm{L}$.

Total coliform was not detected in the April sample from ICPP-MON-PW-024. However, total coliform was identified in the October sample at a concentration of 500 colonies/100 mL. The laboratory performing the analysis identified the species of bacteria detected in ICPP-MON-PW-024 as Klebsiella ozanae.

Similar to the total coliform results, fecal coliform was absent in the April sample but was detected in the October sample at $2 \mathrm{col} / 100 \mathrm{ml}$. The fecal coliform species identified were Klebsiella ozanae and Escherichia coli.

Fecal coliform consists of various genera and species of coliform that are specifically associated with human and animal wastes. The treatment processes at the INTEC STP do not include disinfection of the wastewater. Therefore, the source of coliform bacteria found in well ICPP-MON-PW-024 is probably the INTEC STP effluent.

Total nitrogen concentrations (comprised of $\mathrm{NO}_{2}-\mathrm{N}, \mathrm{NO}_{3}-\mathrm{N}$ and $\mathrm{TKN}$ ) in the perched water closely followed those of the effluent prior to 1997 (Figure 4-4), the difference being that nearly all the total nitrogen in the perched water was comprised of $\mathrm{NO}_{3}-\mathrm{N}$, while the effluent was primarily comprised of $\mathrm{NH}_{3}-\mathrm{N}$. This suggests significant nitrification (a process whereby $\mathrm{NH}_{3}-\mathrm{N}$ is converted to $\mathrm{NO}_{3}-\mathrm{N}$ ) by the soil, but little denitrification to a gas. This can be seen in the April 2003 sample from well ICPP-MON-PW-024 where the $\mathrm{NO}_{3}-\mathrm{N}$ concentration was above the PCS of $10 \mathrm{mg} / \mathrm{L}$.

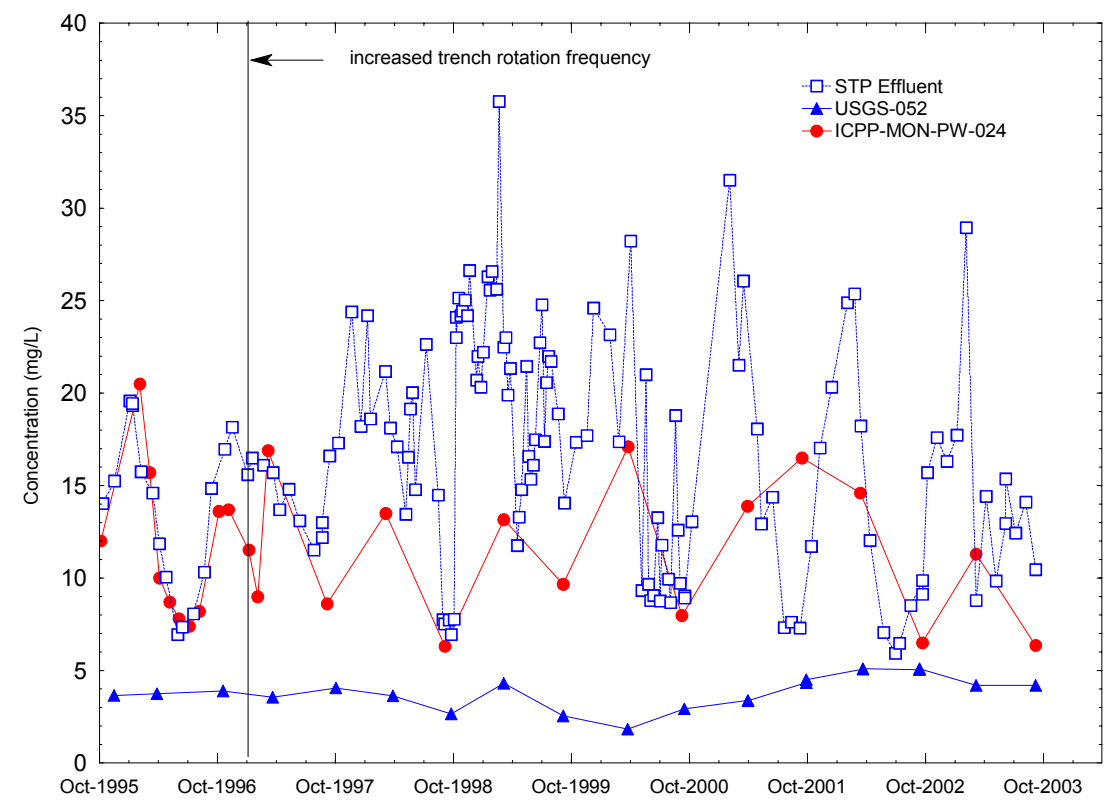

Figure 4-4. Total nitrogen concentrations in Sewage Treatment Plant effluent, ICPP-MON-PW-024, and USGS-052. 
In March 1997, the trench rotation frequency was increased from biweekly to weekly to increase denitrification in the soil column. As shown in Figure 4-4, total nitrogen concentrations in the perched water appear to be reduced compared to that of the effluent, with concentrations generally falling between that of the effluent and that measured at USGS-052. Weekly trench rotation will continue, and concentrations of these parameters will continue to be observed and tracked.

\subsection{Summary of Environmental Impacts}

INTEC STP effluent flow volumes and groundwater concentrations were all within permit limits. The total nitrogen concentration in the effluent exceeded the permit limit $(20 \mathrm{mg} / \mathrm{L})$ in March 2003, and the TSS concentration in the effluent exceeded the permit limit in December $2002(107 \mathrm{mg} / \mathrm{L})$, but the yearly averages for both remained below the applicable permit limit. Numerous maintenance and operational corrective actions have been implemented in the past to manage the total nitrogen concentration in the effluent. In 2003, a proposal to expand the operations associated with the New Percolation Ponds and reroute treated sanitary wastewater from the STP to the New Percolation Ponds was submitted to DEQ. As a result of this operation, the infiltration trenches associated with the STP would be closed and the WLAP for the STP would be terminated.

Concentrations of permit-required parameters in groundwater samples collected from the aquifer compliance well (USGS-052) near the INTEC STP were all within permit limits during 2003. Monitoring well ICPP-MON-PW-024 was constructed in the perched water zone approximately $70 \mathrm{ft}$ below the surface of the infiltration trenches. It is used as an indicator of treatment efficiency of the soil rather than serving as a point of compliance. As in previous years, TDS and chloride concentrations in ICPP-MON-PW-024 approximated those of the effluent. For permit year 2003, the TDS concentration in the October sample was above the SCS of $500 \mathrm{mg} / \mathrm{L}$. Total and fecal coliform were also detected in ICPP-MON-PW-024 in October 2003. Fecal coliform consists of various genera and species of coliform that are specifically associated with human and animal wastes. The treatment processes at the INTEC STP do not include disinfection of the wastewater. Therefore, the source of coliform bacteria found in well ICPP-MON-PW-024 is probably the INTEC STP effluent. 
4-14 


\section{TEST AREA NORTH/TECHNICAL SUPPORT FACILITY SEWAGE TREATMENT PLANT DATA SUMMARY AND ASSESSMENT}

\subsection{Site Description}

The Test Area North (TAN) is located at the north end of the INEEL. Major facilities at TAN include:

- $\quad$ Technical Support Facility (TSF)

- $\quad$ Containment Test Facility (formerly the Loss-of-Fluid-Test Facility)

- $\quad$ Specific Manufacturing Capability Facilities.

Test Area North was initially built between 1954 and 1961 to support the Aircraft Nuclear Propulsion Program sponsored by the U.S. Air Force and the Atomic Energy Commission.

The TSF area currently has approximately 33 buildings and a work force of about 120 people. The TAN/TSF STP only serves the buildings in the TSF area. The TAN/TSF STP and Disposal Pond are southwest of the TSF area and over 1,500 ft away from the nearest drinking water well. A public road passes approximately $1 / 4 \mathrm{mi}$ southeast of the area, and the nearest inhabited building is approximately $1,000 \mathrm{ft}$ from the wastewater application area (Figure 5-1). Groundwater generally flows to the southeast.

\subsection{System Description and Operation}

The TAN/TSF STP was constructed in 1956. It was designed to treat raw wastewater by biologically digesting the majority of the organic waste and other major contaminants, then applying it to land for infiltration and evaporation. The STP consists of:

- Wastewater-collection manhole

- $\quad$ Imhoff tank

- $\quad$ Sludge drying beds

- $\quad$ Trickle filter and settling tank

- $\quad$ Contact basin

- Infiltration disposal pond.

The TAN/TSF Disposal Pond was constructed in 1971; prior to that, treated wastewater was disposed of through an injection well.

The Disposal Pond consists of a primary disposal area and an overflow section, both of which are located within an unlined, fenced 35-acre area. The overflow pond is rarely used; it is used only when the water is diverted to it for brief periods of cleanup and maintenance. The Disposal Pond and overflow pond areas are approximately $39,000 \mathrm{ft}^{2}(0.9$ acres $)$ and $14,400 \mathrm{ft}^{2}(0.330$ acres $)$, respectively, for a combined area of approximately $53,400 \mathrm{ft}^{2}$ (1.23 acres). In addition to receiving treated sewage wastewater, the Disposal Pond also receives process wastewater, which enters the facility at the TAN-655 lift station. 


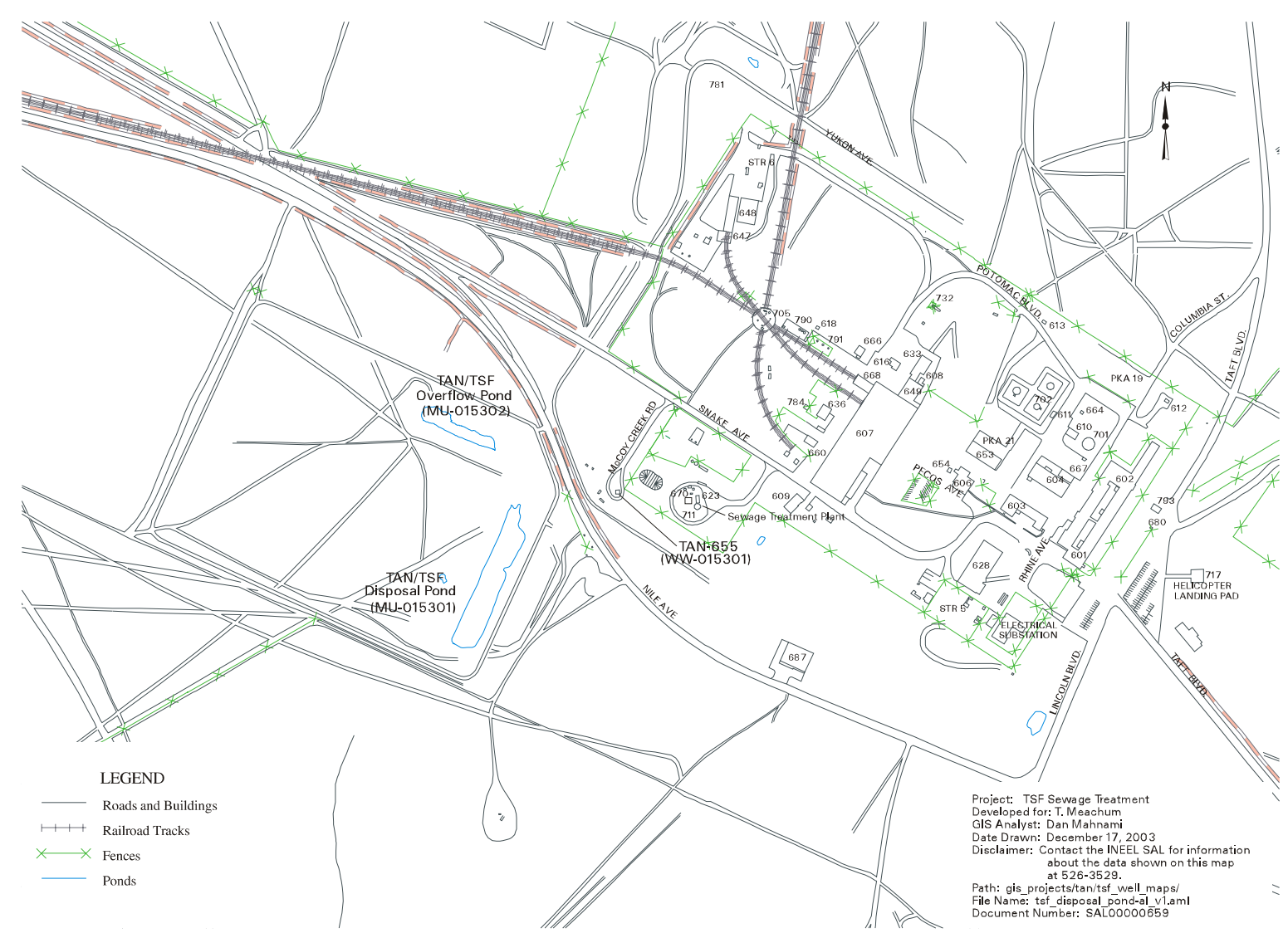

Figure 5-1. Test Area North/Technical Support Facility Sewage Treatment Plant and Wastewater Disposal Pond.

The TSF sewage primarily consists of spent water containing wastes from rest rooms, sinks, and showers. The wastewater goes to the TAN-623 STP, and then to the TAN-655 lift station, which pumps to the Disposal Pond.

The process drain system collects wastewater from process drains and building sources originating from various TAN facilities. The process wastewater consists of effluent, such as steam condensate; water softener and demineralizer discharges; and cooling water, heating, ventilating, air conditioning, and air scrubber discharges. The process wastewater is transported directly to the TAN-655 lift station, where it is mixed with treated sanitary wastewater before being pumped to the Disposal Pond.

Designed output of the STP is 28,800 gpd, but can go up to 36,000 gpd, if necessary. The TAN-655 lift station has a capacity of about 800 gallons per minute (well over 1 million gpd). The pond's capacity, taking into consideration volume losses from evaporation and infiltration, is estimated at $33 \mathrm{MG} / \mathrm{yr}$ (Kaminsky et al. 1993).

\subsection{Status of Special Compliance Conditions}

No special compliance conditions were in effect during the 2003 permit year. 


\subsection{Effluent Monitoring Results}

The permit for the TAN/TSF STP sets concentration limits for TSS and total nitrogen (measured at the effluent to the Disposal Pond) and requires that the effluent be sampled and analyzed monthly for several parameters. During the 2003 permit year, 24-hour composite samples (except fecal and total coliform, which were grab samples) were collected at the TAN-655 lift station effluent monthly. The permit requires that monthly samples be collected as 24-hour, flow-proportional composites. However, due to the configuration of the piping and location of the flow meter, a compositor that collects flow-proportional samples based on real-time measurement of the two incoming waste streams could not be installed. As a result, an annual flow study was started in 1997 to determine the average fluctuations in flow over a 24-hour period. The flow study is repeated every year, and the compositor is reprogrammed based on the average flows measured during different periods of the day to simulate a flow-proportional sample for the year. This method has been used to collect time-weighted, flow-proportional samples since August 1997. The DEQ verbally authorized this method of flow-proportional sampling, and written approval was received in March 2003 (Guymon 2003c).

Table 5-1 shows the effluent monitoring results for the 2003 permit year. Monthly concentrations of TSS were well below the permit limits $(100 \mathrm{mg} / \mathrm{L})$ throughout the entire permit year, with a maximum monthly concentration of $13.6 \mathrm{mg} / \mathrm{L}$ in December 2002. All monthly total nitrogen (TKN + NNN) concentrations were well below the permit limit of $20 \mathrm{mg} / \mathrm{L}$, with the maximum monthly concentration of $11.11 \mathrm{mg} / \mathrm{L}$ in June 2003. Compared to permit year 2002, yearly average concentrations for some of the permit-required parameters were higher. However, all yearly average concentrations were within historic ranges.

\subsubsection{Flow Volumes}

In addition to effluent concentration limits, the permit also specifies a limit for annual effluent flow volume to the Disposal Pond. The flow meter at TAN-655 measures the combined STP and the process wastewater flows, which are joined at the TAN-655 sump before being pumped to the TAN/TSF Disposal Pond. The Disposal Pond consists of a primary disposal area (MU-015301) and an overflow section (MU-015302), which is rarely used. All of the flow during 2003 went to the primary disposal area. Table 5-2 summarizes monthly and total flow volumes, and Appendix D presents daily flow readings and copies of the required electronic WLAP data files (DEQ 2002a).

The permit flow limit is $34 \mathrm{MG}$ per year discharged to the pond. Total effluent to the pond for the 2003 permit year was $8.98 \mathrm{MG}$ based on actual flow meter readings. However, during the permit year, the effluent flow meter failed on March 19, 2003, and was not repaired until June 20, 2003. During this time, the majority of the flows were recorded as zero. Average daily flows for this period are estimated to have been 30,400 gpd based on historical flow data and assumed worst-case scenarios. Using these worst-case estimates, the total effluent to the pond for the permit year is estimated to be approximately $11.78 \mathrm{MG}$, which while higher than that recorded by the flow meters, is still well within the permitted limit.

\subsection{Groundwater Monitoring Results}

To measure potential Disposal Pond impacts to groundwater, the permit requires that groundwater samples be collected from four monitoring wells (see Figure 5-2):

- $\quad$ One background aquifer well (TANT-MON-A-001) upgradient of the Disposal Pond

- Three aquifer wells (TAN-10A, TAN-13A, and TANT-MON-A-002) that serve as points of compliance. 
Table 5-1. Test Area North/Technical Support Facility water data for effluent to the TAN/TSF Disposal Pond (WW-015301).

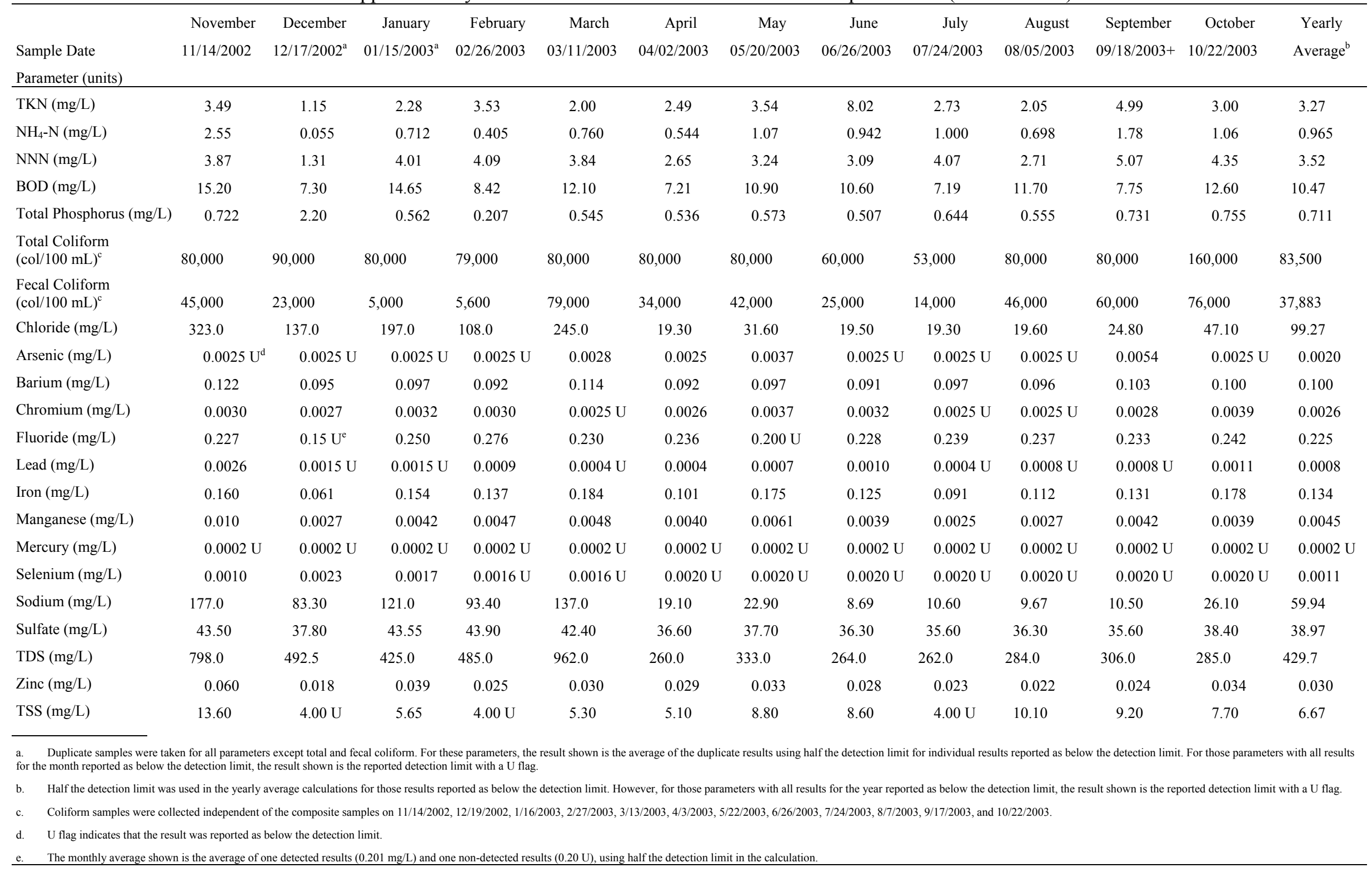


Table 5-2. Test Area North/Technical Support Facility flow summaries.

\begin{tabular}{|c|c|c|c|c|}
\hline \multirow[b]{2}{*}{ Sample Month } & \multicolumn{4}{|c|}{$\begin{array}{l}\text { Effluent to Disposal Pond } \\
\text { (WW-015301) }\end{array}$} \\
\hline & $\begin{array}{l}\text { Average } \\
(\mathrm{gpd})^{\mathrm{a}}\end{array}$ & $\begin{array}{l}\text { Minimum } \\
(\mathrm{gpd})\end{array}$ & $\begin{array}{l}\text { Maximum } \\
(\mathrm{gpd})\end{array}$ & $\begin{array}{c}\text { Total to Primary Disposal } \\
\text { Pond (MU-015301) } \\
(\mathrm{MG})^{\mathrm{b}}\end{array}$ \\
\hline November 2002 & 23,700 & 5,000 & 41,000 & 0.71 \\
\hline December 2002 & 32,161 & 25,000 & 42,000 & 1.00 \\
\hline January 2003 & 32,903 & 28,000 & 37,000 & 1.02 \\
\hline February 2003 & 32,786 & 26,000 & 43,000 & 0.92 \\
\hline March $2003^{c}$ & 19,387 & 1,000 & 35,000 & 0.60 \\
\hline April $2003^{c}$ & 267 & 1,000 & 2,000 & 0.01 \\
\hline May $2003^{c}$ & 32 & 1,000 & 1,000 & 0.00 \\
\hline June $2003^{c}$ & 12,233 & 30,000 & $67,000^{\mathrm{d}}$ & 0.37 \\
\hline July 2003 & 36,968 & 25,000 & 46,000 & 1.15 \\
\hline August 2003 & 40,581 & 30,000 & 50,000 & 1.26 \\
\hline September 2003 & 33,933 & 26,000 & 43,000 & 1.02 \\
\hline October 2003 & 30,226 & 26,000 & 35,000 & 0.94 \\
\hline Yearly Summary & 24,608 & 1,000 & 67,000 & 8.98 \\
\hline \multicolumn{5}{|c|}{$\begin{array}{l}\text { a. gpd-Gallons per day. } \\
\text { b. Annual flow totals are shown in million gallons (MG). } \\
\text { c. The effluent flow meter failed on March 19, 2003, and was repaired on June 20,2003. During this time, the majority of the flows were } \\
\text { recorded as zero. However, a few flows were recorded as either 1,000 gpd or 2,000 gpd. The average and minimum monthly flows shown during } \\
\text { this period are based on the non-zero flow readings. }\end{array}$} \\
\hline \multicolumn{5}{|c|}{$\begin{array}{l}\text { The high flow on June } 25,2003 \text {, was the result of a complete water outage occurring on that day, in which all water hydrants were opened } \\
\text { to allow for the lines to drain. }\end{array}$} \\
\hline
\end{tabular}

Sampling must be conducted semiannually and must include several specified parameters for analysis. Contaminant concentrations in TAN-10A, TAN-13A, and TANT-MON-A-002 are limited by the permit to the PCS and SCS levels in IDAPA 58.01.11, "Ground Water Quality Rule." All permit-required samples are collected as unfiltered samples.

During the 2003 permit year, groundwater samples were collected in April and October. Table 5-3 shows water levels (recorded prior to purging and sampling) and analytical results for all parameters specified by the permit. Iron concentrations exceeded the SCS of $0.3 \mathrm{mg} / \mathrm{L}$ in TAN-10A in April (Guymon 2003d) and October (Gibby 2004). Iron concentrations in additional filtered samples collected in April and October 2003 from TAN-10A also exceeded the SCS. Elevated iron concentrations historically have been detected in the TAN WLAP monitoring wells. Due to increased iron concentrations in all four of the TAN WLAP wells in 1999, a corrosion evaluation (CORRPRO 2000) was performed at TAN wells that exhibited similar increases. This evaluation confirmed that the riser pipes at several TAN wells were significantly corroded and attributed the increased iron concentrations to the corrosion. The riser pipes attached to the dedicated submersible pumps were replaced with stainless steel riser pipes in all four TAN WLAP monitoring wells during August 2001. Video log information gathered during the well maintenance showed that the stainless steel well casings in wells TAN-13A, TANT-MON-A-001, and TANT-MON-A-002 appeared relatively free of rust to the water table. Iron concentrations have decreased 


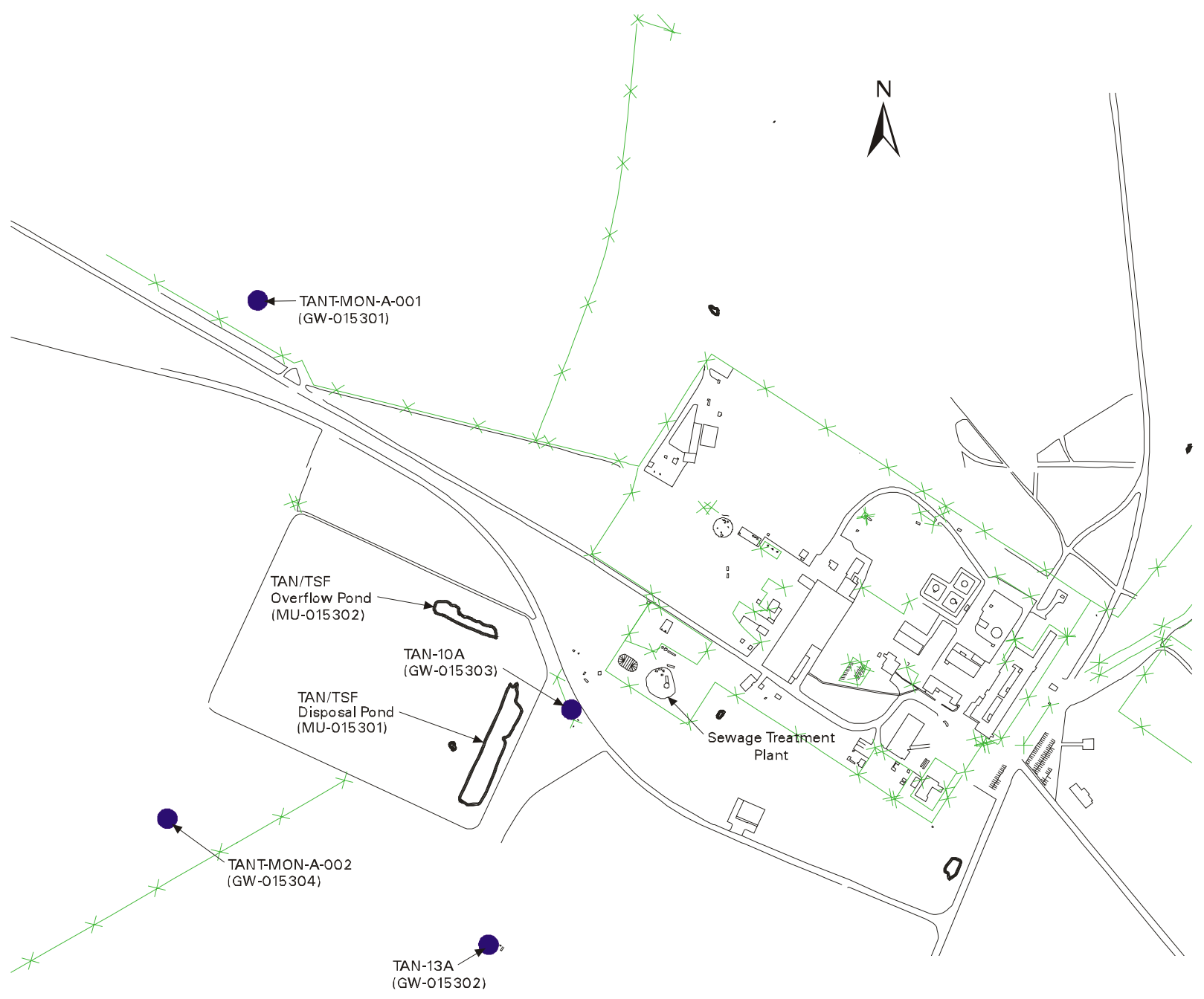

\section{LEGEND}

Roads and Buildings

Fences $\quad$ Date Drawn: December 17, 2003

$\vdash++$ Railroad Tracks

WLAP Monitoring Wells

Path: /gis_projects/tan/wells/

File Name: tan_wlap_sap- ap_v2.aml

Figure 5-2. Locations of Test Area North/Technical Support Facility WLAP monitoring wells. 
Table 5-3. Test Area North/Technical Support Facility Sewage Treatment Plant groundwater data for April and October 2003.

\begin{tabular}{|c|c|c|c|c|c|c|c|c|c|c|c|}
\hline \multirow{2}{*}{$\begin{array}{l}\text { Depth to Water } \\
\text { Table (ft) }\end{array}$} & \multicolumn{2}{|c|}{$\begin{array}{l}\text { TANT-MON-A-001 } \\
\quad(\mathrm{GW}-015301)\end{array}$} & \multicolumn{4}{|c|}{$\begin{array}{l}\text { TANT-MON-A-002 } \\
(\text { GW-015304) }\end{array}$} & \multicolumn{2}{|c|}{$\begin{array}{c}\text { TAN-10A } \\
(\mathrm{GW}-015303)\end{array}$} & \multicolumn{2}{|c|}{$\begin{array}{c}\text { TAN-13A } \\
(\mathrm{GW}-15302)\end{array}$} & \multirow[t]{2}{*}{$\mathrm{PCS} / \mathrm{SCS}^{\mathrm{a}}$} \\
\hline & 206.31 & 207.96 & 210.73 & 210.73 & 211.41 & 211.41 & 206.93 & 209.79 & 209.35 & 209.05 & \\
\hline $\begin{array}{l}\text { Sample Date } \\
\left(\text { units }^{c}\right)\end{array}$ & $\begin{array}{c}4 / 21 / 2003 \\
(\mathrm{mg} / \mathrm{L})\end{array}$ & $\begin{array}{c}10 / 14 / 2003 \\
(\mathrm{mg} / \mathrm{L})\end{array}$ & $\begin{array}{c}4 / 21 / 2003 \\
(\mathrm{mg} / \mathrm{L})\end{array}$ & $\begin{array}{c}4 / 21 / 2003^{b} \\
(\mathrm{mg} / \mathrm{L})\end{array}$ & $\begin{array}{c}10 / 14 / 2003 \\
(\mathrm{mg} / \mathrm{L})\end{array}$ & $\begin{array}{c}10 / 14 / 2003^{\mathrm{b}} \\
(\mathrm{mg} / \mathrm{L})\end{array}$ & $\begin{array}{c}4 / 16 / 2003 \\
(\mathrm{mg} / \mathrm{L})\end{array}$ & $\begin{array}{c}10 / 1 / 2003 \\
(\mathrm{mg} / \mathrm{L})\end{array}$ & $\begin{array}{c}4 / 16 / 2003 \\
(\mathrm{mg} / \mathrm{L})\end{array}$ & $\begin{array}{c}10 / 1 / 2003 \\
(\mathrm{mg} / \mathrm{L})\end{array}$ & $(\mathrm{mg} / \mathrm{L})$ \\
\hline TKN & $0.90 \mathrm{U}^{\mathrm{d}}$ & 2.2 & $1.8 \mathrm{U}$ & $1.8 \mathrm{U}$ & 2.0 & 1.7 & $1.8 \mathrm{U}$ & $1.0 \mathrm{U}$ & $0.90 \mathrm{U}$ & $1.0 \mathrm{U}$ & $\mathrm{NA}^{\mathrm{e}}$ \\
\hline BOD & 2.9 & $2.0 \mathrm{U}$ & 2.6 & 2.8 & $2.0 \mathrm{U}$ & $2.0 \mathrm{U}$ & 3.1 & $2.0 \mathrm{U}$ & $2.0 \mathrm{U}$ & $2.0 \mathrm{U}$ & NA \\
\hline Chloride & 121 & 10.9 & 3.6 & 3.1 & 3.3 & 3.2 & 101 & 99.6 & 7.2 & 3.2 & 250 \\
\hline TDS & 248 & 225 & 225 & 216 & 196 & 188 & 424 & 479 & 147 & 95 & 500 \\
\hline Total Phosphorous & 0.084 & 0.12 & $0.030 \mathrm{U}$ & 0.084 & $0.10 \mathrm{U}$ & $0.10 \mathrm{U}$ & 0.21 & $0.10 \mathrm{U}$ & $0.030 \mathrm{U}$ & $0.50 \mathrm{U}$ & NA \\
\hline Sodium & 7.56 & 7.14 & 5.49 & 5.56 & 5.87 & 5.83 & 51.9 & 48.6 & 5.63 & 5.54 & NA \\
\hline $\mathrm{NO}_{3}-\mathrm{N}$ & 0.83 & 0.79 & 0.48 & 0.51 & 0.50 & 0.52 & 1.1 & 0.83 & 0.40 & 0.40 & 10 \\
\hline $\mathrm{NO}_{2}-\mathrm{N}$ & $0.10 \mathrm{U}$ & $0.10 \mathrm{U}$ & $0.10 \mathrm{U}$ & $0.10 \mathrm{U}$ & $0.10 \mathrm{U}$ & $0.10 \mathrm{U}$ & $0.10 \mathrm{U}$ & $0.10 \mathrm{U}$ & $0.10 \mathrm{U}$ & $0.10 \mathrm{U}$ & 1 \\
\hline $\mathrm{NH}_{4}-\mathrm{N}$ & $0.10 \mathrm{U}$ & $0.10 \mathrm{U}$ & $0.10 \mathrm{U}$ & $0.10 \mathrm{U}$ & $0.10 \mathrm{U}$ & $0.10 \mathrm{U}$ & $0.10 \mathrm{U}$ & $0.10 \mathrm{U}$ & $0.10 \mathrm{U}$ & $0.10 \mathrm{U}$ & NA \\
\hline Arsenic & $0.0025 \mathrm{U}$ & 0.0027 & 0.0027 & $0.0025 \mathrm{U}$ & 0.0027 & 0.0038 & $0.0025 \mathrm{U}$ & $0.0025 \mathrm{U}$ & $0.0025 \mathrm{U}$ & J $0.0025 \mathrm{U}$ & 0.05 \\
\hline Barium & 0.0806 & 0.078 & 0.0800 & 0.0796 & 0.0773 & 0.0769 & 0.241 & 0.242 & 0.0752 & 0.0748 & 2 \\
\hline Chromium & 0.0043 & 0.0042 & 0.0089 & 0.0057 & 0.0079 & 0.0064 & $0.0025 \mathrm{U}$ & $0.0025 \mathrm{U}$ & 0.0044 & 0.0058 & 0.1 \\
\hline Mercury & $0.0002 \mathrm{U}$ & $0.0002 \mathrm{U}$ & $0.0002 \mathrm{U}$ & $0.0002 \mathrm{U}$ & $0.0002 \mathrm{U}$ & $0.0002 \mathrm{U}$ & $0.0002 \mathrm{U}$ & $0.0002 \mathrm{U}$ & $0.0002 \mathrm{U}$ & J $0.0002 \mathrm{U}$ & 0.002 \\
\hline Selenium & $0.0025 \mathrm{U}$ & $0.0025 \mathrm{U}$ & $0.0025 \mathrm{U}$ & $0.0025 \mathrm{U}$ & $0.0025 \mathrm{U}$ & $0.0025 \mathrm{U}$ & $0.0025 \mathrm{U}$ & $0.0025 \mathrm{U}$ & $0.0025 \mathrm{U}$ & J $0.0025 \mathrm{U}$ & 0.05 \\
\hline Fluoride & 0.16 & 0.17 & 0.18 & 0.19 & 0.16 & 0.12 & 0.11 & 0.17 & 0.18 & 0.21 & 4 \\
\hline Iron & 0.0356 & 0.0538 & 0.172 & 0.158 & 0.0935 & 0.0777 & 0.433 & 1.07 & 0.0387 & 0.0932 & 0.3 \\
\hline Iron (filtered) & - & - & - & - & - & - & 0.347 & 0.918 & $0.025 \mathrm{U}$ & 0.0427 & - \\
\hline Lead & $0.0015 \mathrm{U}$ & $0.0015 \mathrm{U}$ & $0.0015 \mathrm{U}$ & $0.0015 \mathrm{U}$ & $0.0015 \mathrm{U}$ & $0.0015 \mathrm{U}$ & $0.0015 \mathrm{U}$ & $0.0015 \mathrm{U}$ & $0.0015 \mathrm{U}$ & $0.0015 \mathrm{U}$ & 0.015 \\
\hline Manganese & $0.0025 \mathrm{U}$ & $0.0025 \mathrm{U}$ & 0.0039 & 0.0034 & $0.0025 \mathrm{U}$ & $0.0025 \mathrm{U}$ & 0.0082 & 0.0111 & $0.0025 \mathrm{U}$ & $0.0025 \mathrm{U}$ & 0.05 \\
\hline Sulfate & 32.8 & 30.8 & 13.3 & 13.4 & 14.0 & 13.6 & 39.6 & 39.5 & 14.2 & 13.8 & 250 \\
\hline Zinc & 0.0506 & 0.0398 & 0.201 & 0.188 & 0.107 & 0.103 & 0.0291 & 0.0226 & 0.171 & 0.174 & 5 \\
\hline Total Coliform & Absent & $4^{\mathrm{f}}$ & Absent & Absent & $17^{\mathrm{f}}$ & $26^{\mathrm{f}}$ & Absent & Absent & Absent & $72^{\mathrm{g}}$ & $1 \mathrm{col} / 100 \mathrm{~mL}$ \\
\hline
\end{tabular}


Table 5-3. (continued).

\begin{tabular}{|c|c|c|c|c|c|c|c|c|c|c|c|}
\hline \multirow{2}{*}{$\begin{array}{c}\text { Depth to Water } \\
\text { Table (ft) }\end{array}$} & \multicolumn{2}{|c|}{$\begin{array}{l}\text { TANT-MON-A-001 } \\
(\text { GW-015301) }\end{array}$} & \multicolumn{4}{|c|}{$\begin{array}{c}\text { TANT-MON-A-002 } \\
\text { (GW-015304) }\end{array}$} & \multicolumn{2}{|c|}{$\begin{array}{c}\text { TAN-10A } \\
(\mathrm{GW}-015303)\end{array}$} & \multicolumn{2}{|c|}{$\begin{array}{l}\text { TAN-13A } \\
\text { (GW-15302) }\end{array}$} & \multirow[t]{2}{*}{$\mathrm{PCS} / \mathrm{SCS}^{\mathrm{a}}$} \\
\hline & 206.31 & 207.96 & 210.73 & 210.73 & 211.41 & 211.41 & 206.93 & 209.79 & 209.35 & 209.05 & \\
\hline $\begin{array}{l}\text { Sample Date } \\
\left(\text { units }^{\text {c }}\right)\end{array}$ & $\begin{array}{c}4 / 21 / 2003 \\
(\mathrm{mg} / \mathrm{L})\end{array}$ & $\begin{array}{c}10 / 14 / 2003 \\
(\mathrm{mg} / \mathrm{L})\end{array}$ & $\begin{array}{c}4 / 21 / 2003 \\
(\mathrm{mg} / \mathrm{L})\end{array}$ & $\begin{array}{c}4 / 21 / 2003^{\mathrm{b}} \\
(\mathrm{mg} / \mathrm{L})\end{array}$ & $\begin{array}{c}10 / 14 / 2003 \\
(\mathrm{mg} / \mathrm{L})\end{array}$ & $\begin{array}{c}10 / 14 / 2003^{\mathrm{b}} \\
(\mathrm{mg} / \mathrm{L})\end{array}$ & $\begin{array}{c}4 / 16 / 2003 \\
(\mathrm{mg} / \mathrm{L})\end{array}$ & $\begin{array}{c}10 / 1 / 2003 \\
(\mathrm{mg} / \mathrm{L})\end{array}$ & $\begin{array}{c}4 / 16 / 2003 \\
(\mathrm{mg} / \mathrm{L})\end{array}$ & $\begin{array}{c}10 / 1 / 2003 \\
(\mathrm{mg} / \mathrm{L})\end{array}$ & $(\mathrm{mg} / \mathrm{L})$ \\
\hline Fecal Coliform & Absent & Absent & Absent & Absent & Absent & Absent & Absent & Absent & Absent & Absent & NA \\
\hline \multicolumn{12}{|c|}{$\begin{array}{l}\text { a. Primary constituent standards (PCS) and secondary constituent standards (SCS) in groundwater referenced in IDAPA 58.01.11.200.01.a and b. } \\
\text { b. Duplicate sample. }\end{array}$} \\
\hline \multicolumn{12}{|c|}{ b. Duplicate sample. } \\
\hline \multicolumn{12}{|c|}{ c. The units for all parameters listed are in $\mathrm{mg} / \mathrm{L}$, except for total and fecal coliform, which are listed as colonies $/ 100 \mathrm{ml}$. } \\
\hline \multicolumn{12}{|c|}{ d. U flag indicates that the result was reported as below the detection limit. } \\
\hline \multicolumn{12}{|c|}{ e. NA-Not applicable } \\
\hline \multicolumn{12}{|c|}{ f. Hafnia alvei was speciated in this sample. } \\
\hline g. Hafnia alvei and & Serratia marc & escens were spe & ciated in this & ample. & & & & & & & \\
\hline
\end{tabular}


in all three of these wells based on samples collected prior to the maintenance (April 2001) and those collected after the maintenance. The iron concentrations in these three wells were below the SCS in both the April and October 2003 sampling events (Table 5-3).

The April 2001 video log information gathered on TAN-10A showed that the carbon steel well casing appeared to be corroded most of the way to the water table. The iron concentrations in TAN-10A increased after the maintenance as reported in the 2002 annual report. In 2003, the iron concentrations in well TAN-10A were again above the SCS in both the April $(0.433 \mathrm{mg} / \mathrm{L})$ and October $(1.07 \mathrm{mg} / \mathrm{L})$ samples. However, the 2003 iron concentrations were lower then those in the October $(3.02 \mathrm{mg} / \mathrm{L}$ and $3.22 \mathrm{mg} / \mathrm{L}$, duplicate) 2002 samples. The condition of the well casing, coupled with the residual effects relating to the replacement of the galvanized riser pipe, may have resulted in the iron concentrations exceeding the SCS in TAN-10A.

All WLAP-required samples and duplicate samples collected from well TAN-10A in 2002 exceeded the SCS for TDS of $500 \mathrm{mg} / \mathrm{L}$. The TDS increased from $509 \mathrm{mg} / \mathrm{L}$ and $540 \mathrm{mg} / \mathrm{L}$ in the April 2002 samples to $568 \mathrm{mg} / \mathrm{L}$ and $627 \mathrm{mg} / \mathrm{L}$ in the October 2002 samples. However, the April 2003 and October 2003 TDS results in TAN-10A were below the SCS at $424 \mathrm{mg} / \mathrm{L}$ and $479 \mathrm{mg} / \mathrm{L}$ (Table 5-3), respectively. The condition of the well casing and the residual effects from replacing the riser pipe (August 2001) may have contributed to well TAN-10A exceeding the TDS SCS in 2002.

In addition to the condition of the well casing and the maintenance activities, TDS in the effluent may also be impacting well TAN-10A. The TDS concentrations in the effluent began to show a significant increase beginning in late 1998 (Figure 5-3). The annual average (permit year) TDS concentration increased from $422 \mathrm{mg} / \mathrm{L}$ in 1998 to $677 \mathrm{mg} / \mathrm{L}$ in 2000 . After installation and subsequent startup of the new water softener system in late 2000, the annual average effluent TDS concentrations began to decrease, until 2003. The annual permit year average TDS concentration in the effluent was $438 \mathrm{mg} / \mathrm{L}$ in $2001,347 \mathrm{mg} / \mathrm{L}$ in 2002, and $430 \mathrm{mg} / \mathrm{L}$ in 2003.

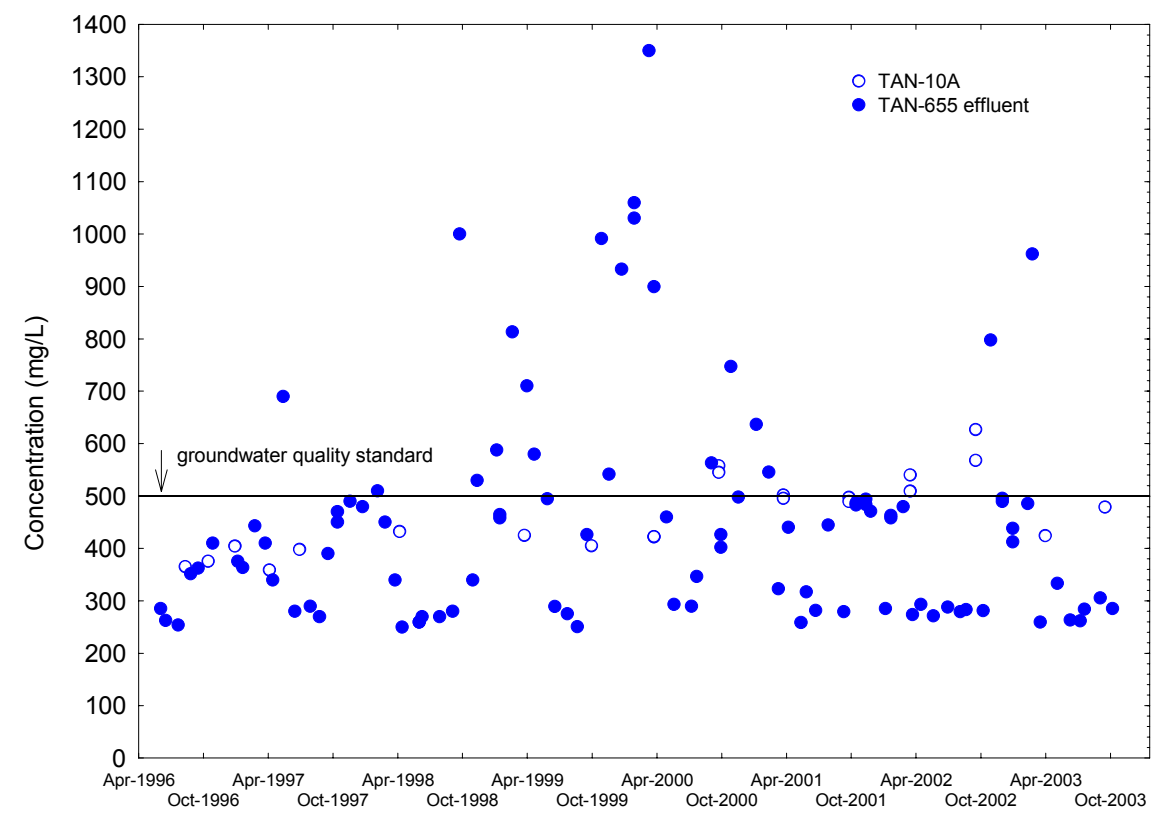

Figure 5-3. Total dissolved solids concentration from Test Area North/Technical Support Facility Well TAN-10A and the effluent (TAN-655). 
Fecal coliform was absent in all samples and wells during the 2003 permit year. In addition, total coliform was absent in all wells for samples collected in April 2003. However, total coliform was identified in TANT-MON-A-001 (background well), TANT-MON-A-002 (compliance well), and TAN-13A (compliance well) in the October samples. The PCS for total coliform is 1 colony/100 $\mathrm{mL}$. The total coliform in wells TANT-MON-A-001, TANT-MON-A-002, and TAN-13A were 4 colonies/100 mL, 17 colonies $/ 100 \mathrm{~mL}$ ( 26 colonies/100 ml, duplicate), and 72 colonies $/ 100 \mathrm{ml}$, respectively. The coliform species identified by the laboratory was Hafnia alvei in wells TANT-MON-A-001 and

TANT-MON-A-002. Two coliform species, Hafnia alvei and Serratia marcescens were identified in well TAN-13A.

The TAN/TSF Disposal Pond effluent contains total coliform bacteria; however, it is unlikely the coliform detected in wells TANT-MON-A-001 and TANT-MON-A-002 was the result of the Disposal Pond effluent. TANT-MON-A-001 is the background well and is not influenced by the Disposal Pond. TANT-MON-A-002 is west/southwest of the Disposal Pond (Figure 5-2), and groundwater flows at TAN are primarily to the south or southeast (DOE-ID 2002, Roback et al. 2001, Johnson et al. 2000); therefore, it is unlikely that bacteria could be transported into the well without significant transverse dispersivity in the vadose zone.

For well TAN-13A, the October 2003 detection is the first time that coliform has been detected in this well since 1996. Because well TAN-13A is located southeast of the Disposal Pond, it is possible that the coliform in the effluent discharged to the pond has affected this well. However, fecal coliform is also present in the effluent but was not detected in TAN-13A.

There are many possible sources for the total coliform detected in the samples from these three wells. Further evaluation will be required to try to identify the specific source of the coliform contamination. If the source can be identified, then appropriate corrective actions can be taken.

Of the three compliance monitoring wells, well TAN-10A exhibited the highest contaminant concentrations (with the exception of total coliform) compared to the background monitoring well. It is difficult, however, to establish a strong relationship between the water quality in TAN-10A and the Disposal Pond due to two factors. First, contaminants in the injectate from a former injection well (located close to TAN-10A and previously used for disposal of numerous waste streams, including those now discharged to the Disposal Pond) are still present in the groundwater and continue to substantially impact groundwater quality. Second, groundwater remediation studies now underway near the former injection well significantly influence local hydraulic gradients and contaminant concentrations near TAN-10A. Groundwater monitoring will continue in TAN-10A (as well as the other three wells) as a part of normal WLAP activities.

No other parameters exceeded permit limits during the 2003 permit year. Monitoring results will continue to be reviewed to specifically monitor parameter concentration changes and the impact of the riser replacements completed during the 2001 permit year.

Four monitoring wells associated with TAN/TSF have been approved for a "no-longer-containedin" (NLCI) determination from DEQ (Monson 1999). The DEQ requires that the volume of purge water placed into the TAN/TSF Disposal Pond as a result of the NLCI determination be reported in the annual WLAP report. These wells include two of the monitoring wells associated with the WLAP (TAN-10A and TAN-13A) and wells TAN-27 and TSFAG-05. During the 2003 permit year, no purge water was discharged to the TAN/TSF Disposal Pond as a result of sampling these wells.

The purge water associated with the April 2003 and October 2003 WLAP sampling of wells TAN-10A and TAN-13A was collected at the time of sampling and turned over to the INEEL Waste 
Generator Services (WGS). The containerized purge water is held in a Resource Conservation and Recovery Act (RCRA) 90-day storage area until characterization of the water is completed by WGS. Based on this characterization, a determination is made on the appropriate disposal path. Currently, if the results of the characterization show that the purge water is not an " $F$ " listed waste in accordance with the NLCI determination, the water is either placed into the TAN-607 Pool or shipped to an off-Site disposal facility. If the water is determined to be an " $F$ " listed waste, the water is shipped to an approved RCRA disposal facility.

During the 2003 permit year, two of these wells (TAN-10A and TAN-27) were sampled in support of the TAN groundwater remediation project, Operable Unit (OU) 1-07B. These sampling efforts are not a requirement of the TAN/TSF WLAP. The purge water generated during the OU 1-07B sampling of wells TAN-10A and TAN-27 was managed in accordance with the OU 1-07B Record of Decision (ROD) (DOE-ID 1995), the OU 1-07B ROD Amendment (DOE-ID 2001), and associated CERCLA documentation, which records agreements reached between the EPA, DEQ, and NE-ID.

Well TSFAG-05 was not sampled during the 2002 permit year.

\subsection{Summary of Environmental Impacts}

The TAN/TSF effluent flow volumes and concentrations were within permit limits. With the exception of total coliform, wells TANT-MON-A-001 (background well), TANT-MON-A-002, and TAN-13A were below their respective PCS and SCS limits for all permit-required constituents monitored in 2003. As in 2002, iron concentrations exceeded the permit limit in well TAN-10A in both April 2003 and October 2003. Elevated iron concentrations historically have been detected in the TAN WLAP monitoring wells. The riser pipes attached to the dedicated submersible pumps were replaced with stainless steel riser pipes in all four TAN WLAP monitoring wells during August 2001. Since the riser pipes were replaced, iron concentrations have decreased in TAN-13A, TANT-MON-A-001, and TANT-MON-A-002. Of the four TAN WLAP wells, TAN-10A is cased with a carbon steel well casing that is corroded most of the way to the water table, and iron concentrations have increased after the maintenance. In 2003, the iron concentrations in well TAN-10A were again above the SCS in both April $(0.433 \mathrm{mg} / \mathrm{L})$ and October $(1.07 \mathrm{mg} / \mathrm{L})$. However, the 2003 iron concentrations were lower then those in October $2002(3.02 \mathrm{mg} / \mathrm{L}$ and $3.22 \mathrm{mg} / \mathrm{L}$, duplicate). The condition of the well casing, coupled with the residual effects of replacing the galvanized riser pipe, may have resulted in the increased iron concentrations in TAN-10A.

Fecal coliform was absent in all of the TAN WLAP wells during the 2003 permit year. In addition, total coliform was absent in all wells in April 2003. However, total coliform was identified in TANT-MON-A-001 (background well), TANT-MON-A-002 (compliance well), and TAN-13A (compliance well) in October 2003. The TAN/TSF Disposal Pond effluent contains total coliform bacteria; however, it is unlikely that the coliform detected in wells TANT-MON-A-001 and TANT-MON-A-002 was the result of the Disposal Pond effluent. For well TAN-13A, the October 2003 detection is the first time that coliform has been detected in this well since 1996. There are many possible sources for the total coliform detected in the samples from these three wells. Further evaluation will be required to try to identify the specific source of the coliform contamination. If the source can be identified, then appropriate corrective actions can be taken. Overall, environmental impacts from TAN/TSF STP operations are considered negligible.

Four monitoring wells associated with the TAN/TSF facility have been approved for a "no-longer-contained-in" determination from DEQ. During the 2002 permit year, no purge water was discharged to the TAN/TSF Disposal Pond as a result of sampling these wells. 


$$
\text { 5-12 }
$$




\section{REFERENCES}

40 CFR 136, 1995, "Guidelines Establishing Test Procedures for the Analysis of Pollutants," Code of Federal Regulations, Office of the Federal Register, August 31, 1995.

Allred, C. S., DEQ, to M. Frei, DOE-ID, November 5, 2001, "Response to DOE Notification of Concerns, WLAP LA-000130-03 INEEL Idaho Nuclear Technology and Engineering Center (INTEC)," CCN 27503.

Bennett, C. M., DOE-ID, to L. Neilsen, DEQ, February 9, 1999, "Wastewater Land Application Permit, \#LA-000141, Renewal Application and Report for the Central Facilities Area Sewage Treatment Plant."

Bohn, H. L., B. L. McNeal, and G. A. O'Connor, 1985, Soil Chemistry, 2nd edition, New York: Wiley and Sons, Inc.

Bruner, D., Cascade Earth Sciences, to T. A. Brock and D. Schiess, INEEL, July 28, 1994, "Revised Water Balances."

CES, 1993, Soil Suitability Investigation for Land Application of Waste Water, Central Facility Area, Idaho National Engineering Laboratory, July 8, 1993.

Clawson, K. L, G. E. Start, and N. R. Ricks, 1989, Climatography of the Idaho National Engineering Laboratory, $2^{\text {nd }}$ edition, DOE/ID-12118, December 1989.

CORRPRO Companies, 2000, Observation Well Pipe Evaluation at Test Area North, January 2000.

Department of Agriculture, 1979, Irrigation Water Requirements, Soil Conservation Service, Engineering Division, Release No. 21.

Department of Agriculture, 1986, Idaho Irrigation Guide, Title 210, Chapter VI, Soil Conservation Services.

DEQ, 2002a, Environmental Monitoring, Data Interpretation, and Annual Report Generation for Wastewater Land Application Facilities, Section 5, "Electronic Data Entry."

DEQ, 2002b, "Procedure for Evaluating Wastewater Treatment Lagoon Seepage Rates," January 22, 2002.

DOE-ID, 1995, Record of Decision for the Technical Support Facility Injection Well (TSF-05) and Surrounding Groundwater Contamination (TSF-23) and Miscellaneous No Action Sites Final Remedial Action, DOE/ID-10139, August 1995.

DOE-ID, 1999, Comprehensive Environmental Response, Compensation and Liability Act (CERCLA) Record of Decision (ROD) for Operating Unit OU 3-13 at the Idaho National Engineering and Environmental Laboratory (INEEL), DOE/ID-10514, September 1999.

DOE-ID, 2001, Record of Decision Amendment for the Technical Support Facility Injection Well (TSF-05) and Surrounding Groundwater Contamination (TSF-023) and Miscellaneous No Action Sites, Final Remedial Action, DOE/ID-10139 Amendment, August 2001. 
DOE-ID, 2002, Idaho National Engineering and Environmental Laboratory Groundwater Monitoring Plan Update, DOE/ID-11034, September 2002.

Eager, G., DEQ, to J. L. Lyle, DOE-ID, and P. H. Divjak, INEEL, September 10, 2001, “INEEL Idaho Nuclear Technology and Engineering Center (INTEC) Wastewater Land Application Permit No. LA-000130-03 (Percolation Ponds).”

Eager, G., DEQ, to J. L. Lyle, DOE-ID, and P. H. Divjak, INEEL, March 28, 2002, "INEEL Idaho Nuclear Technology and Engineering Center (INTEC) Wastewater Land Application Permit No. LA-000130-03 (Percolation Ponds)," CCN 31280.

EG\&G Idaho, Inc., 1993, CFA WLAP Application, Appendix B, Cascade Earth Science, Ltd. Report.

EPA, 1981, Process Design Manual for Land Treatment of Municipal Wastewater, EPA 625/1-81-013, Table 4-26.

EPA, 1984, EPA Method 300.0, Methods for Chemical Analysis of Water and Wastes, EPA-600/144-84-017, March 1984.

Gibby, E. D., INEEL, to G. Eager, DEQ, January 29, 2004, "State Water Self-Disclosure Log," CCN 47293.

Graham, J. F., INEEL, to R. Huddleston, DEQ, November 11, 1998, "Nitrogen Reduction Plan for Idaho Nuclear Technology and Engineering Center (INTEC, formerly ICPP) Sewage Treatment Plant (STP) WLAP \#LA-000115-02," JFG-86-98.

Graham, J. F., INEEL, to G. Eager, DEQ, March 20, 2000, "Wastewater Land Application Permit Renewal Application for the Idaho Nuclear Technology and Engineering Center Sewage Treatment Plant," CCN 00-006031.

Green, O. D., DEQ, to J. M. Wilcynski, DOE-ID, July 27, 1994, “DOE-Central Facilities Area-Sewage Treatment Plant Land Application Permit (INEL-Wastewater Land Application Permit LA-000141-01 (Municipal Wastewater) Response to Comments."

Green, O. D., DEQ, to J. M. Wilcynski, DOE-ID, September 20, 1995, "DOE-Idaho Chemical Processing Plant (ICPP) Sewage Treatment Facility-Land Application Permit (INEL)-Wastewater Land Application Permit LA-000115-02 (Municipal Wastewater).”

Green, O. D., DEQ, to J. M. Wilcynski, DOE-ID, May 9, 1996, “Test Area North Sewage Treatment Facility Wastewater Land Application Permit No. LA-000153-01.”

Guymon, R. H., INEEL, to G. Eager, DEQ, November 2, 2000, "Wastewater Land Application Permit Renewal Application for the Test Area North/Technical Support Facility Sewage Treatment Facility," CCN 14662.

Guymon, R. H., INEEL, to T. Rackow, DEQ, October 23, 2002a, "Cancellation Request for the Idaho National Engineering and Environmental Laboratory's Idaho Nuclear Technology and Engineering Center Existing Percolation Ponds Wastewater Land Application Permit Number LA-000130-02," CCN 36958. 
Guymon, R. H., INEEL, to G. Eager, DEQ, December 17, 2002b, "Submittal of Certification Letter and As-Built Drawings for the Idaho Nuclear Technology and Engineering Center Wastewater Treatment Plant Shear Gate Replacement Project," CCN 38451.

Guymon, R. H., INEEL, to T. A. Rackow, DEQ, January 20, 2003a, "Supporting Information Regarding the Updated Operation and Maintenance Manual for the Idaho National Engineering and Environmental Laboratory Central Facilities Area Sewage Treatment Plant Wastewater Land Application Permit No. LA-000141-01,” CCN 38769.

Guymon, R. H., INEEL to T. A. Rackow, DEQ, June 26, 2003b, "Major Modification Request for the Idaho Nuclear Technology and Engineering Center New Percolation Ponds Wastewater Land Application Permit No. LA-000130-03, INTEC Sewage Treatment Plant Upgrade Project," CCN 43159.

Guymon, R. H., INEEL, to T. A. Rackow, DEQ, March 25, 2003c, "Notice of Completion and Transmittal of the Fate of Nutrients Report for the Idaho Nuclear Technology and Engineering Center New Percolation Ponds," CCN 40534.

Guymon, R. H., INEEL, to G. Eager, DEQ, July 28, 2003d, "State Water Self-Disclosure Log," CCN 43652.

Guymon, R. H., INEEL, to T. A. Rackow, DEQ, January 28, 2003e, "Proposal to Combine the Idaho Nuclear Technology and Engineering Center Sewage Treatment Plant Effluent with the Service Waste System Effluent," CCN 39439.

Guymon, R. H., INEEL, to G. Eager, DEQ, January 29, 2003f, "State Water Self-Disclosure Log," CCN 39298.

Guymon, R. H., INEEL, to G. Eager, DEQ, May 27, 2003g, "State Water Self-Disclosure Log," CCN 42478.

Hukari, N., NOAA, e-mail to M. Lewis, INEEL, "INEEL Climate Summary,” December 11, 2003, CCN 46874.

IDAPA 58.01.11, 1997, “Ground Water Quality Rule," Idaho Administrative Procedures Act, Idaho Department of Health and Welfare, March 27, 1997.

INEEL, 2000, 1999 Annual Wastewater Land Application Site Performance Reports for the Idaho National Engineering and Environmental Laboratory, INEEL/EXT-2000-00078, February 2000.

INEEL, 2002, Surface Aeration Treatment for Nitrogen Reduction at INTEC's Sewage Treatment Plant-Final Report, April 11, 2001-April 26, 2002, INEEL/EXT-02-00869, August 2002.

INEEL, 2003a, 2002 Annual Wastewater Land Application Site Performance Reports for the Idaho National Engineering and Environmental Laboratory, INEEL/EXT-02-01562, February 2003.

INEEL, 2003b, Central Facilities Area Landfills I, II, and III Annual Monitoring Report (2002), INEEL/EXT-03-00024, September 2003.

Johnson, T. M., R. C. Roback, T. L. McLing, T. D. Bullen, D. J. DePaolo, C. Doughty, R. J. Hunt, M. T. Murrell, and R. W. Smith, 2000, 'Groundwater 'Fast Paths' in the Snake River Plain 
Aquifer: Radiogenic Isotope Ratios as Natural Groundwater Tracers," Geology, Vol. 28, pp. 871-874.

Johnston, J., DEQ, to J. Graham, INEEL, September 18, 2000, "INEEL Central Facilities Area (CFA)."

Johnston, J., DEQ, to S. Madson, DOE-ID, January 19, 2001, "INEEL Idaho Nuclear Technology and Engineering Center (INTEC) Sewage Treatment Plant (WLAP No. 000115-02)."

Kaminsky, J. F., et al., 1993, Remedial Investigation Final Report with Addenda for the Test Area North Groundwater Operable Unit at the Idaho National Engineering Laboratory, EGG-ER-10643, Revision 0, December 1993.

Linsley, R. K., M. A. Kohler, and J. L. H. Paulhus, 1982, Hydrology for Engineers, $3^{\text {rd }}$ Volume, New York: McGraw-Hill.

MacConnel, M., INEEL, e-mail to R. Kauffman, et al., DOE-ID, K. Miller, et al., INEEL, "August 29, 2002 DEQ Memo of Conversation - New Perc Ponds Alternative Analytical Methods," September 4, 2002, CCN 35564.

Maloney, S., Cascade Earth Sciences, to D. Schiess, INEEL, June 9, 1993, "Soil Water Balances for the Proposed Land Application Site at the Central Facility Area (CFA)."

Metcalf and Eddy, Inc., 1979, Wastewater Engineering: Treatment Disposal Reuse, New York: McGraw-Hill.

Monson, B. R., DEQ, to D. Wessman, DOE-ID, July 30, 1999, "Response to June 1, 1999, Request for a "no-longer-contained-in" (NLCI) Determination for Six (6) Monitoring Wells Associated with the Wastewater Land Application Permit Wells at the TAN Facility (OFE-EP\&SA-88-89) on the Idaho National Engineering and Environmental Laboratory (INEEL), EPA ID No. ID4980008952.”

Page, A. L. (editor), 1982, Methods of Soil Analysis, Part 2, "Chemical and Microbiological Properties," 2nd edition, Madison, Wisconsin: American Society of Agronomy.

Rackow, T. A., DEQ, to R. Guymon, INEEL, November 4, 2002a, "Cancellation Request for Wastewater Land Application Permit No. LA-000130-02 (Existing Percolation Ponds)," CCN 37330.

Rackow, T. A, DEQ, to J. Graham, INEEL, February, 25, 2002b, "Review and Comments on the Updated Operation and Maintenance Manual for the INEEL Central Facilities Area Sewage Treatment Plant Wastewater Land Application Permit No. LA-000141-01."

Rackow, T. A., DEQ, to R. H. Guymon, INEEL, April 2, 2003a, "Central Facilities Area (CFA) Sewage Treatment Plant (STP) O\&M Manual and Soil Phosphorus Analysis. Wastewater Land Application Permit No. LA-000141-01," CCN 41724.

Rackow, T. A., DEQ, to C. S. Mascarenas, INEEL, November 17, 2003b, "INEEL INTEC New Perc Ponds, Extension for Compliance Activity No. CA-130-02, Wastewater land Application Permit (WLAP) No. LA-000130-03 (Industrial Wastewater)," CCN 46464.

Rackow, T. A., DEQ, to R. H. Guymon, INEEL, April 14, 2003c, "BBWI/DOE-ID Proposal to Combine the INTEC Sewage Treatment Plant Effluent with the INTEC Service Waste System Effluent 
Wastewater Land Application Permit No.'s LA-000130-03 (INTEC New Perc Ponds), and LA-000115-02 (INTEC Sewage Treatment Facility)," CCN 41678.

Roback R. C., T. M. Johnson, T. L. McLing, M. T. Murrell, S. Luo, and T. L. Ku, 2001, "Uranium Isotopic Evidence for Groundwater Chemical Evolution and Flow Patterns in the Eastern Snake River Plain Aquifer, Idaho," Geol. Soc. Amer. Bull., Vol. 113, pp.1133-1141.

Robertson, J. B, R. Schoen, and J. T. Barraclough (USGS), 1974, The Influence of Liquid Waste Disposal on the Geochemistry of Water at the National Reactor Testing Station, Idaho: 1952-1970, IDO-22053.

Rugg, J. E., INEEL, to G. Eager, DEQ, November 29, 2001, “Submittal of Updated Operation and Maintenance Manual for Central Facilities Area Sewage Treatment Plant (WLAP Permit No. LA-000141-01)," CCN 27844.

Rugg, J. E., INEEL, to G. Eager, DEQ, April 9, 2002, "Response to Comments on the Updated Operation and Maintenance (O\&M) Manual for the Idaho National Engineering and Environmental Laboratory (INEEL) Central Facilities Area Sewage Treatment Plant (CFA STP) [Wastewater Land Application Permit (WLAP) No. LA-000141-01]," CCN 31343.

Teuscher, W., DEQ, to J. F. Graham, INEEL, July 12, 2001, "Request for Continued Operation for Land Application Permit \#LA-000153-01."

Teuscher, W., DEQ, to R. Guymon, INEEL, December 23, 2002, "INTEC Record Drawings for WWTP Shear Gate Replacement Project DEQ \#02-03-12,” CCN 38701. 
6-6 


\section{Appendix A}

Central Facilities Area Sewage Treatment Plant Daily Influent and Effluent Flow Readings, Sewage Treatment Plant Photographs, and Electronic Data Files 


$$
\text { A-2 }
$$




\section{Appendix A}

\section{Central Facilities Area Sewage Treatment Plant Daily Influent and Effluent Flow Readings, Sewage Treatment Plant Photographs, and Electronic Data Files}

Table A-1. Central Facilities Area Sewage Treatment Plant daily influent and effluent flows.

\begin{tabular}{|c|c|c|c|c|c|}
\hline Date & $\begin{array}{c}\text { Influent to } \\
\text { Lagoon } \\
\text { (WW-014101) } \\
\left(\mathrm{gpd}^{\mathrm{a}}\right) \\
\end{array}$ & $\begin{array}{c}\text { Effluent to Pivot } \\
(\mathrm{WW}-014102) \\
\left(\mathrm{gpd}^{\mathrm{a}}\right)\end{array}$ & Date & 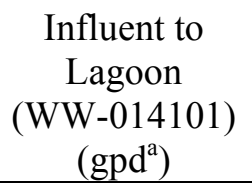 & $\begin{array}{c}\text { Effluent to } \\
\text { Pivot } \\
\text { (WW-014102) } \\
\left(\mathrm{gpd}^{\mathrm{a}}\right) \\
\end{array}$ \\
\hline $12 / 1 / 2002$ & 70,433 & $\mathrm{NF}^{\mathrm{b}}$ & $12 / 26 / 2002$ & 67,383 & $\mathrm{NF}$ \\
\hline $12 / 2 / 2002$ & 75,736 & NF & $12 / 27 / 2002$ & 49,298 & NF \\
\hline $12 / 3 / 2002$ & 93,830 & NF & $12 / 28 / 2002$ & 67,087 & NF \\
\hline $12 / 4 / 2002$ & 97,229 & NF & $12 / 29 / 2002$ & 69,532 & $\mathrm{NF}$ \\
\hline $12 / 5 / 2002$ & 104,673 & NF & $12 / 30 / 2002$ & 53,333 & $\mathrm{NF}$ \\
\hline $12 / 6 / 2002$ & 88,366 & NF & $12 / 31 / 2002$ & 61,289 & NF \\
\hline $12 / 7 / 2002$ & 71,479 & NF & $1 / 1 / 2003$ & 60,809 & NF \\
\hline $12 / 8 / 2002$ & 70,817 & NF & $1 / 2 / 2003$ & 71,170 & NF \\
\hline $12 / 9 / 2002$ & 78,516 & NF & $1 / 3 / 2003$ & 63,378 & NF \\
\hline $12 / 10 / 2002$ & 92,282 & $\mathrm{NF}$ & $1 / 4 / 2003$ & 58,886 & NF \\
\hline $12 / 11 / 2002$ & 97,484 & NF & $1 / 5 / 2003$ & 61,675 & $\mathrm{NF}$ \\
\hline $12 / 12 / 2002$ & 95,307 & NF & $1 / 6 / 2003$ & 82,110 & $\mathrm{NF}$ \\
\hline $12 / 13 / 2002$ & 92,071 & NF & $1 / 7 / 2003$ & 86,087 & NF \\
\hline $12 / 14 / 2002$ & 64,002 & NF & $1 / 8 / 2003$ & 91,562 & $\mathrm{NF}$ \\
\hline $12 / 15 / 2002$ & 73,035 & NF & $1 / 9 / 2003$ & 96,947 & $\mathrm{NF}$ \\
\hline $12 / 16 / 2002$ & 70,170 & NF & $1 / 10 / 2003$ & 80,133 & NF \\
\hline $12 / 17 / 2002$ & 91,022 & NF & $1 / 11 / 2003$ & 74,807 & NF \\
\hline $12 / 18 / 2002$ & 90,661 & NF & $1 / 12 / 2003$ & 65,954 & NF \\
\hline $12 / 19 / 2002$ & 86,062 & NF & $1 / 13 / 2003$ & 78,850 & NF \\
\hline $12 / 20 / 2002$ & 78,035 & NF & $1 / 14 / 2003$ & 106,169 & NF \\
\hline $12 / 21 / 2002$ & 65,606 & $\mathrm{NF}$ & $1 / 15 / 2003$ & 98,337 & $\mathrm{NF}$ \\
\hline $12 / 22 / 2002$ & 63,238 & NF & $1 / 16 / 2003$ & 100,361 & $\mathrm{NF}$ \\
\hline $12 / 23 / 2002$ & 62,886 & NF & $1 / 17 / 2003$ & 81,596 & NF \\
\hline $12 / 24 / 2002$ & 72,054 & $\mathrm{NF}$ & $1 / 18 / 2003$ & 66,548 & NF \\
\hline $12 / 25 / 2002$ & 66,939 & NF & $1 / 19 / 2003$ & 72,059 & NF \\
\hline
\end{tabular}


Table A-1. (continued).

\begin{tabular}{|c|c|c|c|c|c|}
\hline Date & $\begin{array}{c}\text { Influent to } \\
\text { Lagoon } \\
\text { (WW-014101) } \\
\left(\mathrm{gpd}^{\mathrm{a}}\right)\end{array}$ & $\begin{array}{c}\text { Effluent to Pivot } \\
\text { (WW-014102) } \\
\left(\mathrm{gpd}^{\mathrm{a}}\right)\end{array}$ & Date & $\begin{array}{c}\text { Influent to } \\
\text { Lagoon } \\
\text { (WW-014101) } \\
\left(\mathrm{gpd}^{\mathrm{a}}\right)\end{array}$ & $\begin{array}{c}\text { Effluent to } \\
\text { Pivot } \\
\text { (WW-014102) } \\
\left(\mathrm{gpd}^{\mathrm{a}}\right)\end{array}$ \\
\hline $1 / 20 / 2003$ & 68,125 & $\mathrm{NF}$ & $2 / 19 / 2003$ & 98,706 & $\mathrm{NF}$ \\
\hline $1 / 21 / 2003$ & 92,218 & $\mathrm{NF}$ & $2 / 20 / 2003$ & 103,273 & $\mathrm{NF}$ \\
\hline $1 / 22 / 2003$ & 87,685 & $\mathrm{NF}$ & $2 / 21 / 2003$ & 78,703 & $\mathrm{NF}$ \\
\hline $1 / 23 / 2003$ & 100,118 & $\mathrm{NF}$ & $2 / 22 / 2003$ & 67,648 & $\mathrm{NF}$ \\
\hline $1 / 24 / 2003$ & 83,396 & $\mathrm{NF}$ & $2 / 23 / 2003$ & 63,443 & $\mathrm{NF}$ \\
\hline $1 / 25 / 2003$ & 72,187 & $\mathrm{NF}$ & $2 / 24 / 2003$ & 64,771 & $\mathrm{NF}$ \\
\hline $1 / 26 / 2003$ & 68,390 & $\mathrm{NF}$ & $2 / 25 / 2003$ & 85,067 & $\mathrm{NF}$ \\
\hline $1 / 27 / 2003$ & 76,865 & $\mathrm{NF}$ & $2 / 26 / 2003$ & 85,333 & $\mathrm{NF}$ \\
\hline $1 / 28 / 2003$ & 97,114 & $\mathrm{NF}$ & $2 / 27 / 2003$ & 86,773 & $\mathrm{NF}$ \\
\hline $1 / 29 / 2003$ & 94,723 & $\mathrm{NF}$ & $2 / 28 / 2003$ & 82,105 & $\mathrm{NF}$ \\
\hline $1 / 30 / 2003$ & 93,356 & $\mathrm{NF}$ & $3 / 1 / 2003$ & 61,606 & $\mathrm{NF}$ \\
\hline $1 / 31 / 2003$ & 88,497 & $\mathrm{NF}$ & $3 / 2 / 2003$ & 60,571 & $\mathrm{NF}$ \\
\hline $2 / 1 / 2003$ & 71,740 & $\mathrm{NF}$ & $3 / 3 / 2003$ & 73,367 & NF \\
\hline $2 / 2 / 2003$ & 67,335 & $\mathrm{NF}$ & $3 / 4 / 2003$ & 90,886 & $\mathrm{NF}$ \\
\hline $2 / 3 / 2003$ & 67,244 & $\mathrm{NF}$ & $3 / 5 / 2003$ & 84,759 & $\mathrm{NF}$ \\
\hline $2 / 4 / 2003$ & 94,588 & $\mathrm{NF}$ & $3 / 6 / 2003$ & 82,303 & $\mathrm{NF}$ \\
\hline $2 / 5 / 2003$ & 90,475 & NF & $3 / 7 / 2003$ & 79,949 & NF \\
\hline $2 / 6 / 2003$ & 99,206 & $\mathrm{NF}$ & $3 / 8 / 2003$ & 65,088 & $\mathrm{NF}$ \\
\hline $2 / 7 / 2003$ & 80,911 & $\mathrm{NF}$ & $3 / 9 / 2003$ & 60,801 & $\mathrm{NF}$ \\
\hline $2 / 8 / 2003$ & 58,806 & $\mathrm{NF}$ & $3 / 10 / 2003$ & 72,513 & $\mathrm{NF}$ \\
\hline $2 / 9 / 2003$ & 60,974 & $\mathrm{NF}$ & $3 / 11 / 2003$ & 100,871 & $\mathrm{NF}$ \\
\hline $2 / 10 / 2003$ & 67,595 & $\mathrm{NF}$ & $3 / 12 / 2003$ & 101,763 & $\mathrm{NF}$ \\
\hline $2 / 11 / 2003$ & 102,329 & $\mathrm{NF}$ & $3 / 13 / 2003$ & 98,456 & $\mathrm{NF}$ \\
\hline $2 / 12 / 2003$ & 96,631 & $\mathrm{NF}$ & $3 / 14 / 2003$ & 97,922 & $\mathrm{NF}$ \\
\hline $2 / 13 / 2003$ & 86,030 & $\mathrm{NF}$ & $3 / 15 / 2003$ & 71,702 & $\mathrm{NF}$ \\
\hline $2 / 14 / 2003$ & 78,714 & $\mathrm{NF}$ & $3 / 16 / 2003$ & 70,208 & $\mathrm{NF}$ \\
\hline $2 / 15 / 2003$ & 67,590 & $\mathrm{NF}$ & $3 / 17 / 2003$ & 68,007 & $\mathrm{NF}$ \\
\hline $2 / 16 / 2003$ & 72,488 & $\mathrm{NF}$ & $3 / 18 / 2003$ & 114,566 & $\mathrm{NF}$ \\
\hline $2 / 17 / 2003$ & 63,408 & $\mathrm{NF}$ & $3 / 19 / 2003$ & 103,500 & $\mathrm{NF}$ \\
\hline $2 / 18 / 2003$ & 90,179 & $\mathrm{NF}$ & $3 / 20 / 2003$ & 113,771 & $\mathrm{NF}$ \\
\hline
\end{tabular}


Table A-1. (continued).

\begin{tabular}{|c|c|c|c|c|c|}
\hline Date & $\begin{array}{c}\text { Influent to } \\
\text { Lagoon } \\
\text { (WW-014101) } \\
\left(\mathrm{gpd}^{\mathrm{a}}\right) \\
\end{array}$ & $\begin{array}{c}\text { Effluent to Pivot } \\
(\mathrm{WW}-014102) \\
\left(\mathrm{gpd}^{\mathrm{a}}\right)\end{array}$ & Date & $\begin{array}{c}\text { Influent to } \\
\text { Lagoon } \\
\text { (WW-014101) } \\
\left(\mathrm{gpd}^{\mathrm{a}}\right)\end{array}$ & $\begin{array}{c}\text { Effluent to } \\
\text { Pivot } \\
\text { (WW-014102) } \\
\left(\mathrm{gpd}^{\mathrm{a}}\right)\end{array}$ \\
\hline $3 / 21 / 2003$ & 91,810 & NF & $4 / 20 / 2003$ & 83,358 & $\mathrm{NF}$ \\
\hline $3 / 22 / 2003$ & 72,800 & $\mathrm{NF}$ & $4 / 21 / 2003$ & 62,766 & $\mathrm{NF}$ \\
\hline $3 / 23 / 2003$ & 91,222 & NF & $4 / 22 / 2003$ & 104,081 & NF \\
\hline $3 / 24 / 2003$ & 50,963 & NF & $4 / 23 / 2003$ & 103,477 & NF \\
\hline $3 / 25 / 2003$ & 99,560 & $\mathrm{NF}$ & $4 / 24 / 2003$ & 104,161 & $\mathrm{NF}$ \\
\hline $3 / 26 / 2003$ & 88,143 & $\mathrm{NF}$ & $4 / 25 / 2003$ & 93,955 & $\mathrm{NF}$ \\
\hline $3 / 27 / 2003$ & 85,775 & NF & $4 / 26 / 2003$ & 66,450 & NF \\
\hline $3 / 28 / 2003$ & 80,609 & NF & $4 / 27 / 2003$ & 60,669 & NF \\
\hline $3 / 29 / 2003$ & 64,944 & NF & $4 / 28 / 2003$ & 74,231 & NF \\
\hline $3 / 30 / 2003$ & 67,784 & NF & $4 / 29 / 2003$ & 95,459 & NF \\
\hline $3 / 31 / 2003$ & 78,789 & NF & $4 / 30 / 2003$ & 85,134 & NF \\
\hline $4 / 1 / 2003$ & 107,227 & NF & $5 / 1 / 2003$ & 102,949 & NF \\
\hline $4 / 2 / 2003$ & 88,927 & $\mathrm{NF}$ & $5 / 2 / 2003$ & 80,389 & $\mathrm{NF}$ \\
\hline $4 / 3 / 2003$ & 89,171 & $\mathrm{NF}$ & $5 / 3 / 2003$ & 79,764 & NF \\
\hline $4 / 4 / 2003$ & 83,764 & NF & $5 / 4 / 2003$ & 62,695 & NF \\
\hline $4 / 5 / 2003$ & 62,497 & $\mathrm{NF}$ & $5 / 5 / 2003$ & 74,485 & $\mathrm{NF}$ \\
\hline $4 / 6 / 2003$ & 59,748 & NF & $5 / 6 / 2003$ & 98,170 & NF \\
\hline $4 / 7 / 2003$ & 65,026 & $\mathrm{NF}$ & $5 / 7 / 2003$ & 96,829 & $\mathrm{NF}$ \\
\hline $4 / 8 / 2003$ & 92,194 & NF & $5 / 8 / 2003$ & 103,205 & NF \\
\hline $4 / 9 / 2003$ & 108,291 & $\mathrm{NF}$ & $5 / 9 / 2003$ & 91,002 & NF \\
\hline $4 / 10 / 2003$ & 105,617 & $\mathrm{NF}$ & $5 / 10 / 2003$ & 73,855 & $\mathrm{NF}$ \\
\hline $4 / 11 / 2003$ & 90,523 & NF & $5 / 11 / 2003$ & 68,934 & $\mathrm{NF}$ \\
\hline $4 / 12 / 2003$ & 80,163 & NF & $5 / 12 / 2003$ & 81,057 & $\mathrm{NF}$ \\
\hline $4 / 13 / 2003$ & 82,642 & NF & $5 / 13 / 2003$ & 89,436 & NF \\
\hline $4 / 14 / 2003$ & 79,523 & $\mathrm{NF}$ & $5 / 14 / 2003$ & 108,162 & $\mathrm{NF}$ \\
\hline $4 / 15 / 2003$ & 94,451 & $\mathrm{NF}$ & $5 / 15 / 2003$ & 113,255 & $\mathrm{NF}$ \\
\hline $4 / 16 / 2003$ & 92,622 & NF & $5 / 16 / 2003$ & 105,040 & $\mathrm{NF}$ \\
\hline $4 / 17 / 2003$ & 96,369 & NF & $5 / 17 / 2003$ & 79,610 & $\mathrm{NF}$ \\
\hline $4 / 18 / 2003$ & 91,620 & NF & $5 / 18 / 2003$ & 76,482 & NF \\
\hline $4 / 19 / 2003$ & 66,918 & $\mathrm{NF}$ & $5 / 19 / 2003$ & 68,577 & NF \\
\hline
\end{tabular}


Table A-1. (continued).

\begin{tabular}{|c|c|c|c|c|c|}
\hline Date & $\begin{array}{c}\text { Influent to } \\
\text { Lagoon } \\
\text { (WW-014101) } \\
\left(\mathrm{gpd}^{\mathrm{a}}\right) \\
\end{array}$ & $\begin{array}{c}\text { Effluent to Pivot } \\
\text { (WW-014102) } \\
\left(\mathrm{gpd}^{\mathrm{a}}\right)\end{array}$ & Date & $\begin{array}{c}\text { Influent to } \\
\text { Lagoon } \\
\text { (WW-014101) } \\
\left(\mathrm{gpd}^{\mathrm{a}}\right) \\
\end{array}$ & $\begin{array}{c}\text { Effluent to } \\
\text { Pivot } \\
\text { (WW-014102) } \\
\left(\mathrm{gpd}^{\mathrm{a}}\right) \\
\end{array}$ \\
\hline $5 / 20 / 2003$ & 103,186 & $\mathrm{NF}$ & $6 / 19 / 2003$ & 159,840 & 163,200 \\
\hline $5 / 21 / 2003$ & 144,607 & NF & $6 / 20 / 2003$ & 154,452 & NF \\
\hline $5 / 22 / 2003$ & 74,582 & NF & $6 / 21 / 2003$ & 74,027 & NF \\
\hline $5 / 23 / 2003$ & 117,500 & NF & $6 / 22 / 2003$ & 88,138 & NF \\
\hline $5 / 24 / 2003$ & 85,037 & NF & $6 / 23 / 2003$ & 98,874 & $\mathrm{NF}$ \\
\hline $5 / 25 / 2003$ & 93,718 & NF & $6 / 24 / 2003$ & 127,748 & 158,500 \\
\hline $5 / 26 / 2003$ & 91,912 & NF & $6 / 25 / 2003$ & 134,476 & 160,600 \\
\hline $5 / 27 / 2003$ & 109,114 & NF & $6 / 26 / 2003$ & 138,318 & 157,200 \\
\hline $5 / 28 / 2003$ & 128,170 & NF & $6 / 27 / 2003$ & 133,776 & NF \\
\hline $5 / 29 / 2003$ & 153,865 & NF & $6 / 28 / 2003$ & 109,570 & $\mathrm{NF}$ \\
\hline $5 / 30 / 2003$ & 133,890 & NF & $6 / 29 / 2003$ & 99,911 & $\mathrm{NF}$ \\
\hline $5 / 31 / 2003$ & 105,263 & NF & $6 / 30 / 2003$ & 128,839 & 142,200 \\
\hline $6 / 1 / 2003$ & 91,152 & NF & $7 / 1 / 2003$ & 147,628 & 153,700 \\
\hline $6 / 2 / 2003$ & 101,704 & NF & $7 / 2 / 2003$ & 143,280 & 151,900 \\
\hline $6 / 3 / 2003$ & 129,927 & NF & $7 / 3 / 2003$ & 158,235 & 159,000 \\
\hline $6 / 4 / 2003$ & 131,531 & NF & $7 / 4 / 2003$ & 133,439 & NF \\
\hline $6 / 5 / 2003$ & 135,612 & NF & $7 / 5 / 2003$ & 103,574 & NF \\
\hline $6 / 6 / 2003$ & 116,809 & NF & $7 / 6 / 2003$ & 127,059 & NF \\
\hline $6 / 7 / 2003$ & 102,057 & $\mathrm{NF}$ & $7 / 7 / 2003$ & 105,756 & $\mathrm{NF}$ \\
\hline $6 / 8 / 2003$ & 78,502 & NF & $7 / 8 / 2003$ & 145,877 & $\mathrm{NF}$ \\
\hline $6 / 9 / 2003$ & 99,633 & NF & $7 / 9 / 2003$ & 152,783 & 160,000 \\
\hline $6 / 10 / 2003$ & 132,366 & NF & $7 / 10 / 2003$ & 147,611 & 161,800 \\
\hline $6 / 11 / 2003$ & 122,940 & NF & $7 / 11 / 2003$ & 151,299 & NF \\
\hline $6 / 12 / 2003$ & 135,964 & NF & $7 / 12 / 2003$ & 33,218 & $\mathrm{NF}$ \\
\hline $6 / 13 / 2003$ & 120,310 & NF & $7 / 13 / 2003$ & 20,637 & NF \\
\hline $6 / 14 / 2003$ & 100,841 & NF & $7 / 14 / 2003$ & 129,727 & NF \\
\hline $6 / 15 / 2003$ & 97,569 & NF & $7 / 15 / 2003$ & 82,176 & 156,400 \\
\hline $6 / 16 / 2003$ & 118,938 & 162,900 & $7 / 16 / 2003$ & 137,474 & $\mathrm{NF}$ \\
\hline $6 / 17 / 2003$ & 135,906 & 139,600 & $7 / 17 / 2003$ & 169,098 & NF \\
\hline $6 / 18 / 2003$ & 178,156 & 162,700 & $7 / 18 / 2003$ & 154,048 & $\mathrm{NF}$ \\
\hline
\end{tabular}


Table A-1. (continued).

\begin{tabular}{|c|c|c|c|c|c|}
\hline Date & 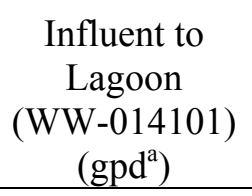 & $\begin{array}{c}\text { Effluent to Pivot } \\
\text { (WW-014102) } \\
\left(\mathrm{gpd}^{\mathrm{a}}\right)\end{array}$ & Date & 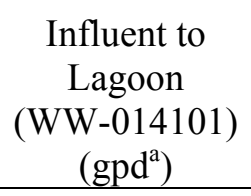 & $\begin{array}{c}\text { Effluent to } \\
\text { Pivot } \\
\text { (WW-014102) } \\
\left(\mathrm{gpd}^{\mathrm{a}}\right)\end{array}$ \\
\hline $7 / 19 / 2003$ & 130,902 & NF & $8 / 18 / 2003$ & 141,499 & $\mathrm{NF}$ \\
\hline $7 / 20 / 2003$ & 127,483 & NF & $8 / 19 / 2003$ & 165,548 & 159,000 \\
\hline $7 / 21 / 2003$ & 139,984 & NF & $8 / 20 / 2003$ & 171,110 & 159,300 \\
\hline $7 / 22 / 2003$ & 162,612 & $\mathrm{NF}$ & $8 / 21 / 2003$ & 182,924 & 158,200 \\
\hline $7 / 23 / 2003$ & 168,881 & 162,800 & $8 / 22 / 2003$ & 169,032 & $\mathrm{NF}$ \\
\hline $7 / 24 / 2003$ & 166,344 & $\mathrm{NF}$ & $8 / 23 / 2003$ & 141,522 & $\mathrm{NF}$ \\
\hline $7 / 25 / 2003$ & 188,795 & $\mathrm{NF}$ & $8 / 24 / 2003$ & 118,121 & $\mathrm{NF}$ \\
\hline $7 / 26 / 2003$ & 121,140 & $\mathrm{NF}$ & $8 / 25 / 2003$ & 142,776 & $\mathrm{NF}$ \\
\hline $7 / 27 / 2003$ & 130,012 & NF & $8 / 26 / 2003$ & 174,225 & 157,300 \\
\hline $7 / 28 / 2003$ & 133,159 & $\mathrm{NF}$ & $8 / 27 / 2003$ & 174,995 & 158,800 \\
\hline $7 / 29 / 2003$ & 162,771 & $\mathrm{NF}$ & $8 / 28 / 2003$ & 186,645 & 158,300 \\
\hline $7 / 30 / 2003$ & 152,729 & 165,400 & $8 / 29 / 2003$ & 159,133 & $\mathrm{NF}$ \\
\hline $7 / 31 / 2003$ & 179,800 & 150,700 & $8 / 30 / 2003$ & 118,899 & $\mathrm{NF}$ \\
\hline $8 / 1 / 2003$ & 151,651 & $\mathrm{NF}$ & $8 / 31 / 2003$ & 117,110 & $\mathrm{NF}$ \\
\hline $8 / 2 / 2003$ & 141,370 & NF & $9 / 1 / 2003$ & 118,718 & $\mathrm{NF}$ \\
\hline $8 / 3 / 2003$ & 144,098 & NF & $9 / 2 / 2003$ & 142,620 & $\mathrm{NF}$ \\
\hline $8 / 4 / 2003$ & 132,661 & NF & $9 / 3 / 2003$ & 157,147 & 158,400 \\
\hline $8 / 5 / 2003$ & 95,065 & 148,900 & $9 / 4 / 2003$ & 168,036 & 159,700 \\
\hline $8 / 6 / 2003$ & 163,021 & $\mathrm{NF}$ & $9 / 5 / 2003$ & 168,057 & $\mathrm{NF}$ \\
\hline $8 / 7 / 2003$ & 188,256 & $\mathrm{NF}$ & $9 / 6 / 2003$ & 126,693 & $\mathrm{NF}$ \\
\hline $8 / 8 / 2003$ & 149,076 & NF & $9 / 7 / 2003$ & 130,349 & $\mathrm{NF}$ \\
\hline 8/9/2003 & 145,945 & NF & 9/8/2003 & 140,714 & $\mathrm{NF}$ \\
\hline $8 / 10 / 2003$ & 117,664 & $\mathrm{NF}$ & 9/9/2003 & 133,874 & NF \\
\hline $8 / 11 / 2003$ & 152,823 & NF & $9 / 10 / 2003$ & 144,661 & 162,500 \\
\hline $8 / 12 / 2003$ & 170,469 & 159,100 & $9 / 11 / 2003$ & 152,111 & 156,500 \\
\hline $8 / 13 / 2003$ & 171,936 & 159,100 & $9 / 12 / 2003$ & 145,282 & NF \\
\hline $8 / 14 / 2003$ & 166,705 & 158,700 & $9 / 13 / 2003$ & 109,246 & $\mathrm{NF}$ \\
\hline $8 / 15 / 2003$ & 175,177 & $\mathrm{NF}$ & $9 / 14 / 2003$ & 96,830 & NF \\
\hline $8 / 16 / 2003$ & 152,553 & NF & $9 / 15 / 2003$ & 106,653 & 155,500 \\
\hline $8 / 17 / 2003$ & 130,783 & $\mathrm{NF}$ & $9 / 16 / 2003$ & 125,430 & 157,400 \\
\hline
\end{tabular}


Table A-1. (continued).

\begin{tabular}{|c|c|c|c|c|c|}
\hline Date & 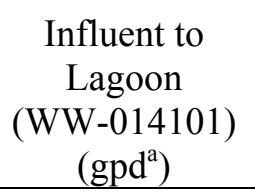 & $\begin{array}{c}\text { Effluent to Pivot } \\
\text { (WW-014102) } \\
\left(\mathrm{gpd}^{\mathrm{a}}\right)\end{array}$ & Date & 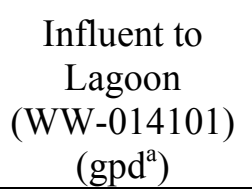 & $\begin{array}{c}\text { Effluent to } \\
\text { Pivot } \\
\text { (WW-014102) } \\
\left(\mathrm{gpd}^{\mathrm{a}}\right)\end{array}$ \\
\hline $9 / 17 / 2003$ & 128,701 & 157,600 & $10 / 16 / 2003$ & 109,855 & $\mathrm{NF}$ \\
\hline $9 / 18 / 2003$ & 126,728 & 150,300 & $10 / 17 / 2003$ & 104,613 & NF \\
\hline 9/19/2003 & 109,303 & $\mathrm{NF}$ & $10 / 18 / 2003$ & 69,239 & $\mathrm{NF}$ \\
\hline $9 / 20 / 2003$ & 103,155 & NF & $10 / 19 / 2003$ & 84,688 & $\mathrm{NF}$ \\
\hline $9 / 21 / 2003$ & 100,260 & NF & $10 / 20 / 2003$ & 103,492 & NF \\
\hline $9 / 22 / 2003$ & 104,761 & NF & $10 / 21 / 2003$ & 116,383 & $\mathrm{NF}$ \\
\hline $9 / 23 / 2003$ & 141,755 & 158,300 & $10 / 22 / 2003$ & 111,420 & $\mathrm{NF}$ \\
\hline $9 / 24 / 2003$ & 131,230 & 157,900 & $10 / 23 / 2003$ & 128,935 & NF \\
\hline $9 / 25 / 2003$ & 148,234 & 156,600 & $10 / 24 / 2003$ & 104,040 & NF \\
\hline $9 / 26 / 2003$ & 155,116 & $\mathrm{NF}$ & $10 / 25 / 2003$ & 88,396 & $\mathrm{NF}$ \\
\hline $9 / 27 / 2003$ & 104,510 & NF & $10 / 26 / 2003$ & 94,806 & $\mathrm{NF}$ \\
\hline $9 / 28 / 2003$ & 127,237 & NF & $10 / 27 / 2003$ & 91,294 & NF \\
\hline $9 / 29 / 2003$ & 127,507 & NF & $10 / 28 / 2003$ & 121,453 & NF \\
\hline $9 / 30 / 2003$ & 145,376 & NF & $10 / 29 / 2003$ & 121,041 & NF \\
\hline $10 / 1 / 2003$ & 141,663 & NF & $10 / 30 / 2003$ & 117,892 & NF \\
\hline $10 / 2 / 2003$ & 142,106 & $\mathrm{NF}$ & $10 / 31 / 2003$ & 99,420 & NF \\
\hline $10 / 3 / 2003$ & 136,022 & NF & $11 / 1 / 2003$ & 87,907 & NF \\
\hline $10 / 4 / 2003$ & 97,890 & NF & $11 / 2 / 2003$ & 79,630 & $\mathrm{NF}$ \\
\hline $10 / 5 / 2003$ & 96,153 & $\mathrm{NF}$ & $11 / 3 / 2003$ & 93,853 & NF \\
\hline $10 / 6 / 2003$ & 107,313 & NF & $11 / 4 / 2003$ & 99,817 & $\mathrm{NF}$ \\
\hline $10 / 7 / 2003$ & 133,597 & NF & $11 / 5 / 2003$ & 101,983 & NF \\
\hline $10 / 8 / 2003$ & 133,651 & $\mathrm{NF}$ & $11 / 6 / 2003$ & 98,674 & NF \\
\hline $10 / 9 / 2003$ & 131,347 & NF & $11 / 7 / 2003$ & 77,514 & NF \\
\hline $10 / 10 / 2003$ & 114,356 & NF & $11 / 8 / 2003$ & 69,494 & NF \\
\hline $10 / 10 / 2003$ & 114,356 & NF & $11 / 9 / 2003$ & 71,847 & $\mathrm{NF}$ \\
\hline $10 / 11 / 2003$ & 84,451 & NF & $11 / 10 / 2003$ & 78,257 & NF \\
\hline $10 / 12 / 2003$ & 174,677 & NF & $11 / 11 / 2003$ & 91,429 & NF \\
\hline $10 / 13 / 2003$ & 97,232 & $\mathrm{NF}$ & $11 / 12 / 2003$ & 93,812 & $\mathrm{NF}$ \\
\hline $10 / 14 / 2003$ & 112,397 & NF & $11 / 13 / 2003$ & 98,537 & $\mathrm{NF}$ \\
\hline $10 / 15 / 2003$ & 122,203 & $\mathrm{NF}$ & $11 / 14 / 2003$ & 102,473 & NF \\
\hline
\end{tabular}


Table A-1. (continued).

\begin{tabular}{rcc|ccc}
\hline & $\begin{array}{c}\text { Influent to } \\
\text { Lagoon } \\
(\mathrm{WW-014101)} \\
\left(\mathrm{gpd}^{\mathrm{a}}\right)\end{array}$ & $\begin{array}{c}\text { Effluent to Pivot } \\
(\mathrm{WW-014102}) \\
\left(\mathrm{gpd}^{\mathrm{a}}\right)\end{array}$ & Date & $\begin{array}{c}\text { Influent to } \\
\text { Lagoon } \\
(\mathrm{WW-014101)} \\
\left(\mathrm{gpd}^{\mathrm{a}}\right)\end{array}$ & $\begin{array}{c}\text { Effluent to } \\
\text { Pivot } \\
(\mathrm{WW}-014102) \\
\left(\mathrm{gpd}^{\mathrm{a}}\right)\end{array}$ \\
\hline $11 / 15 / 2003$ & 78,244 & $\mathrm{NF}$ & $11 / 23 / 2003$ & 69,735 & $\mathrm{NF}$ \\
$11 / 16 / 2003$ & 80,739 & $\mathrm{NF}$ & $11 / 24 / 2003$ & 71,321 & $\mathrm{NF}$ \\
$11 / 17 / 2003$ & 81,388 & $\mathrm{NF}$ & $11 / 25 / 2003$ & 92,778 & $\mathrm{NF}$ \\
$11 / 18 / 2003$ & 98,582 & $\mathrm{NF}$ & $11 / 26 / 2003$ & 89,038 & $\mathrm{NF}$ \\
$11 / 19 / 2003$ & 114,132 & $\mathrm{NF}$ & $11 / 27 / 2003$ & 96,459 & $\mathrm{NF}$ \\
$11 / 20 / 2003$ & 103,492 & $\mathrm{NF}$ & $11 / 28 / 2003$ & 66,999 & $\mathrm{NF}$ \\
$11 / 21 / 2003$ & 90,007 & $\mathrm{NF}$ & $11 / 29 / 2003$ & 66,633 & $\mathrm{NF}$ \\
$11 / 22 / 2003$ & 68,754 & $\mathrm{NF}$ & $11 / 30 / 2003$ & 77,779 & $\mathrm{NF}$ \\
\hline a. $\quad$ gpd-Gallons per day. & & & & \\
b. NF-No flow. & & & & \\
\hline
\end{tabular}




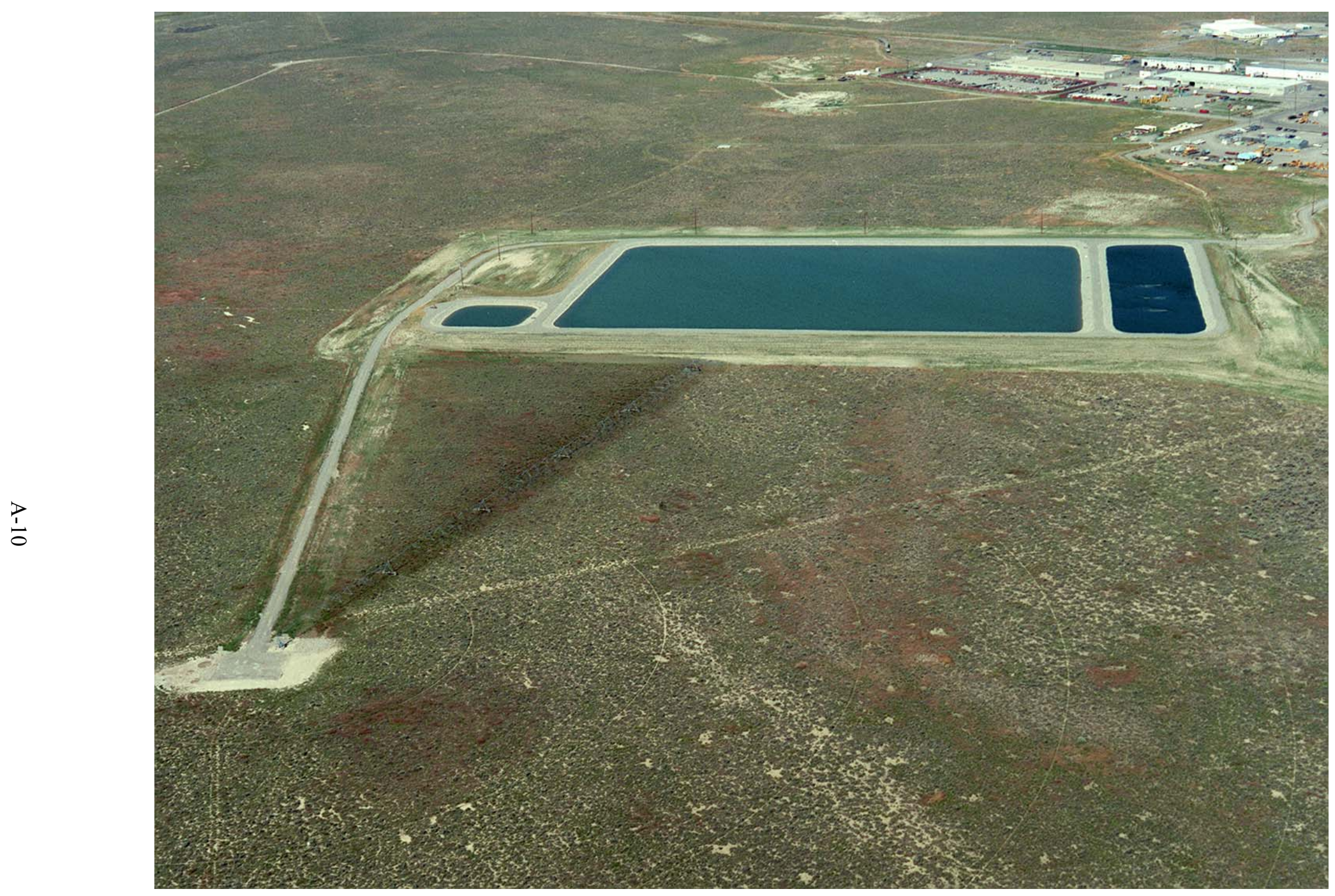

Figure A-1. Central Facilities Area Sewage Treatment Plant, 1995 (95-627-7-4). 




Figure A-2. Central Facilities Area Sewage Treatment Plant, 1996 (96-174-9-8). 


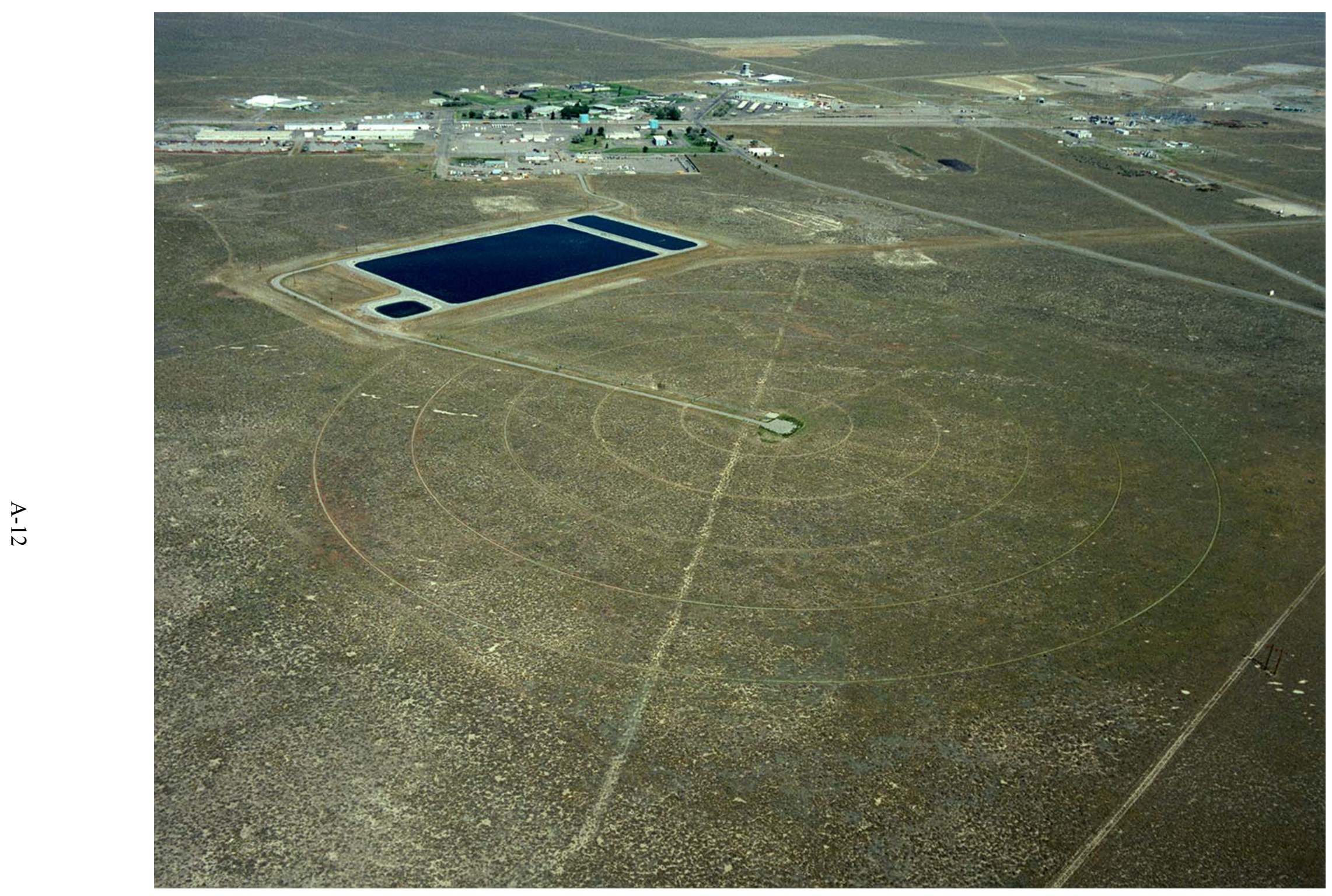

Figure A-3. Central Facilities Area Sewage Treatment Plant, 1997 (97-620-5-14). 


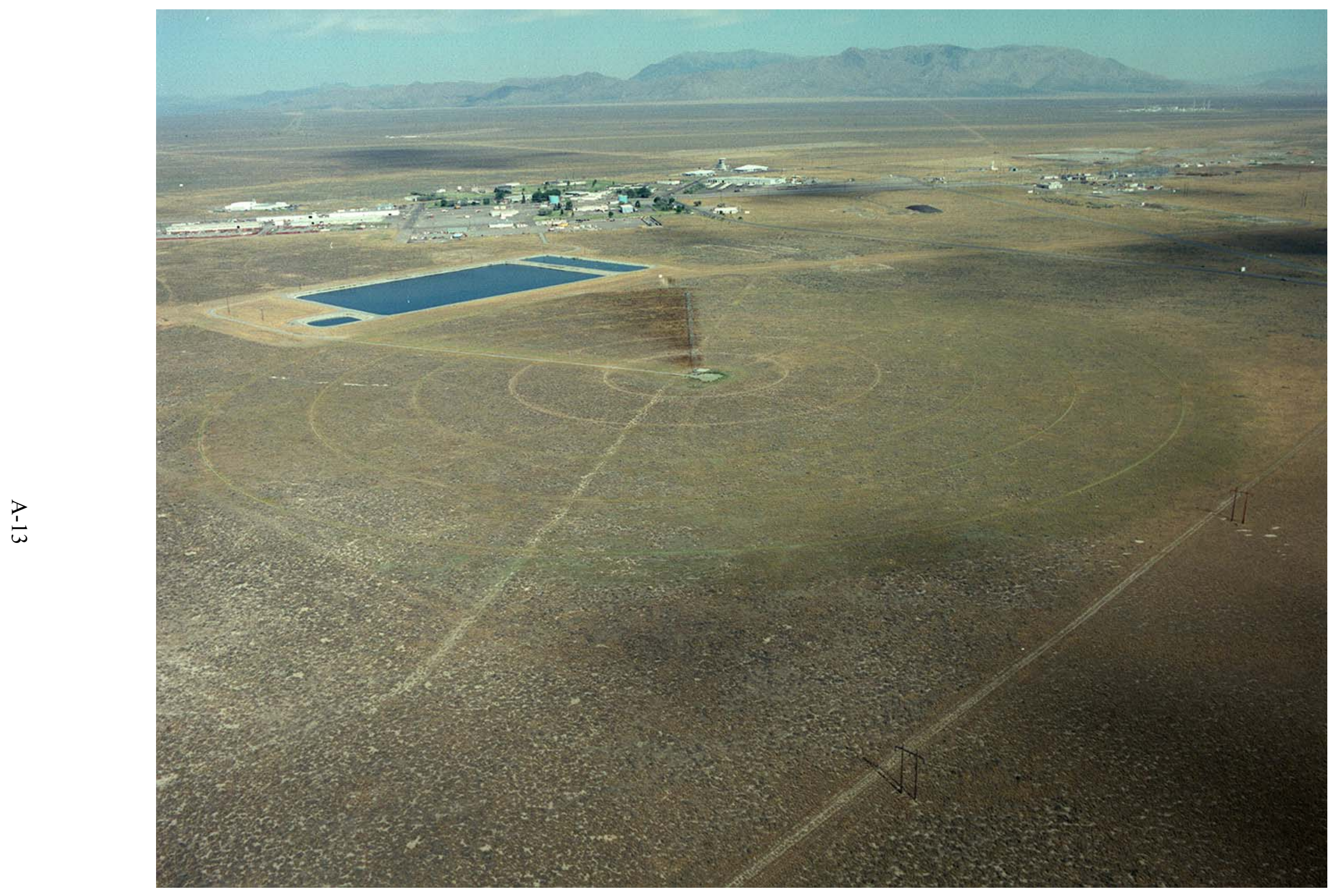

Figure A-4. Central Facilities Area Sewage Treatment Plant, 1998 (98-454-11-6). 


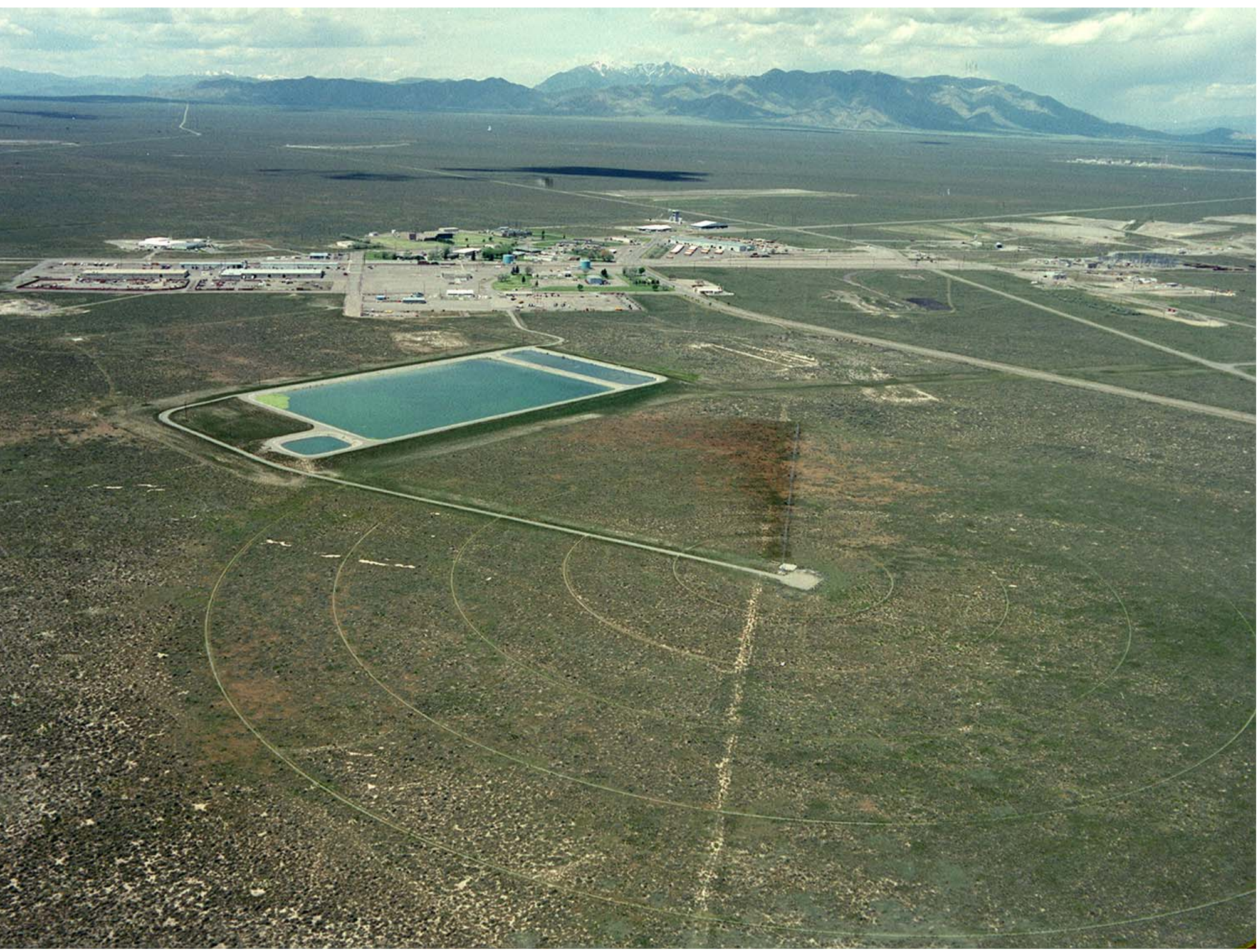

Figure A-5. Central Facilities Area Sewage Treatment Plant, 1999 (99-344-10-9). 


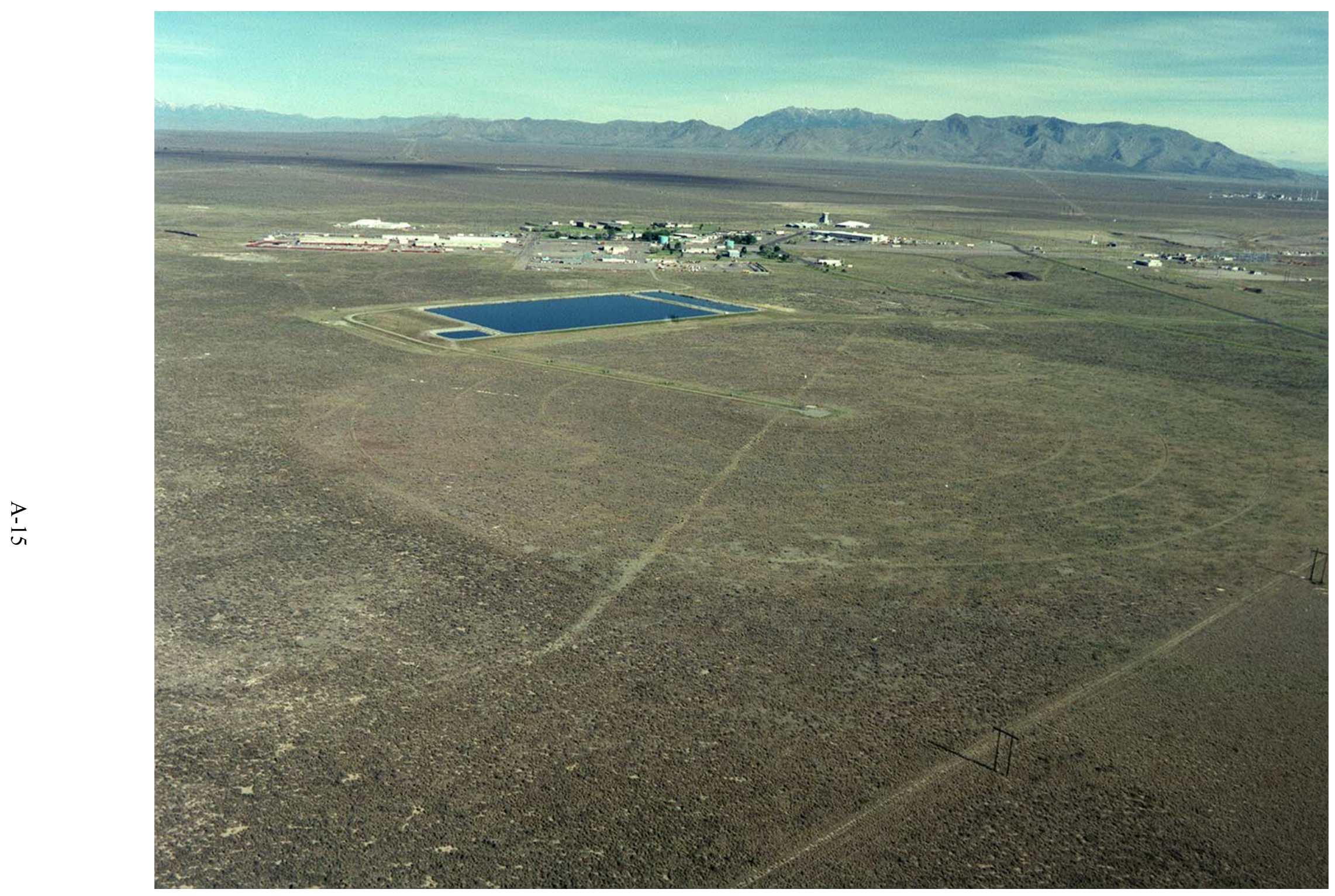

Figure A-6. Central Facilities Area Sewage Treatment Plant, 2000 (00-296-2-2). 


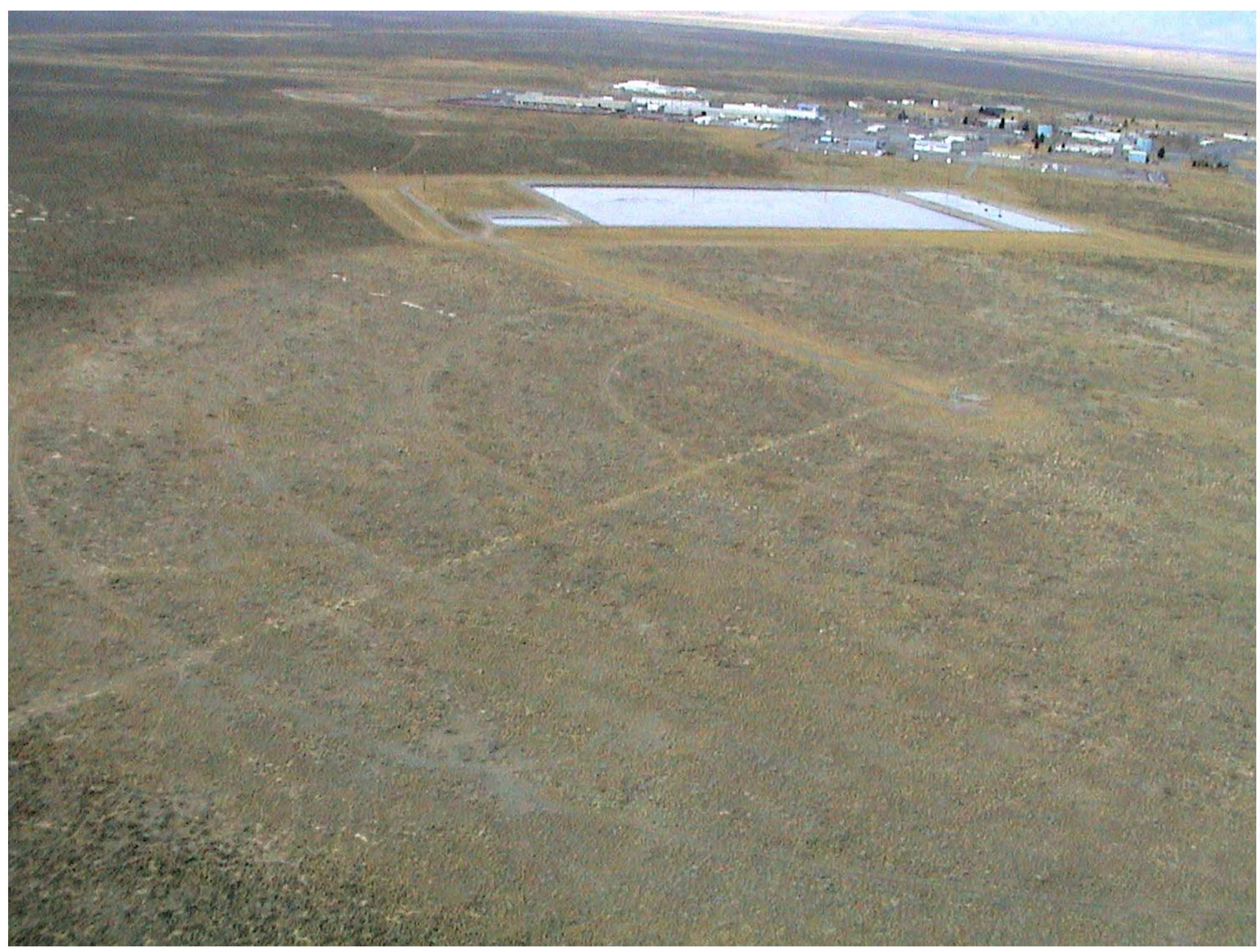

Figure A-7. Central Facilities Area Sewage Treatment Plant, 2002 (PD020741-02). 


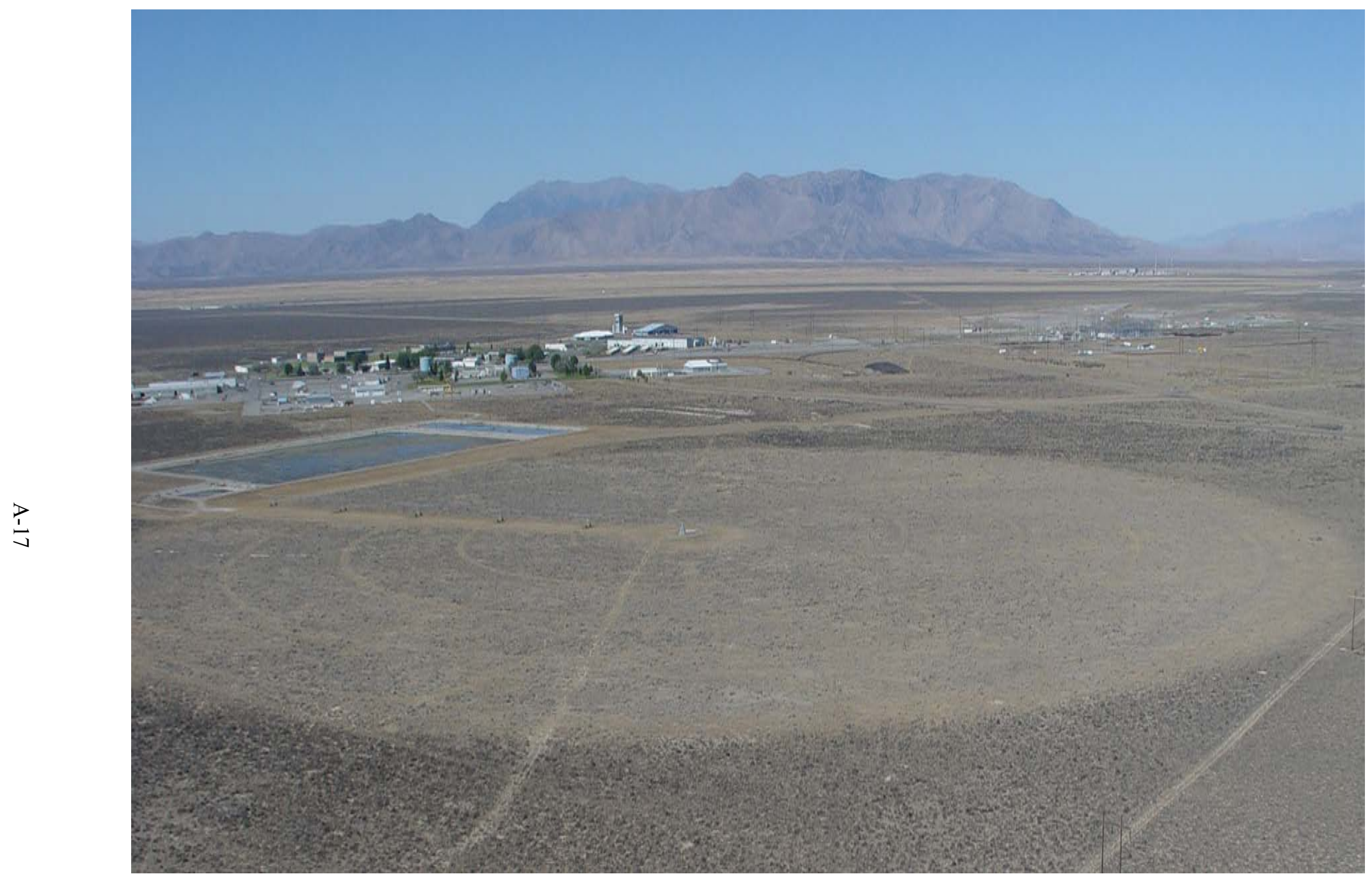

Figure A-8. Central Facilities Area Sewage Treatment Plant, 2003 (PD030339-01) 
The following tables (Tables A-2 through A-6) represent hardcopies of the electronic WLAP data files required by the DEQ (DEQ 2002a). Section 5, "Electronic Data Entry," of DEQ 2002a, states "assemble data tables (electronic tables) with other parts of the annual report." The following tables were first compiled as worksheets within the WLAP Data Entry for LA-141-1.xls file using Microsoft Excel 97. The individual worksheets were saved as text files and incorporated as tables in this appendix. Other than formatting to fit the page, and tabulating the data columns, no other formatting was performed. Columns for those parameters not required by the permit are not included in the tables, nor are rejected results shown in these data tables. 
Table A-2. Hydraulic Worksheet from WLAP Data Entry for LA-141-1.XLS

LAND APPLICATION OF WASTEWATER PROGRAM

ANNUAL REPORT FORMS

For Reporting Year -> 2002-2003

WLAP Permit No.--> LA-000141-01

Software and Version no.:-----> MS Excel 97 SR-2

HYDRAULIC APPLICATION RATE

\begin{tabular}{|l|l|l|l|l|l|l|}
\hline & & & & Suppl & & \\
\hline & Month & Manage- & WW & Irrig W & & \\
\hline Permit & (use 15th & ment & Applied & Applied & & \\
\hline No. & as date) & Unit & (MG) & (MG) & & \\
\hline permitno & month & mangunit & wwapp & irrwapp & & \\
\hline LA-000141 & $6 / 15 / 03$ & MU-014101 & 1.25 & & & \\
\hline LA-000141 & $7 / 15 / 03$ & MU-014101 & 1.42 & & & \\
\hline LA-000141 & $8 / 15 / 03$ & MU-014101 & 1.58 & & & \\
\hline LA-000141 & $9 / 15 / 03$ & MU-014101 & 1.73 & & & \\
\hline
\end{tabular}

Note: 1. Dates here denote each month of the year.

2 . These dates by convention shall be the 15 th of the month.

3. Each twelve month cycle is repeated for each management unit.

4. If the management unit was not used for land application, enter all zeros.

5. For monthly date, use date function.

6. Do not change any protected cell.

3. Make sure units for data entered are consistent with units specified in column headings. 
Table A-3. MU Summary Worksheet from WLAP Data Entry for LA-141-1.XLS

LAND APPLICATION OF WASTEWATER PROGRAM

ANNUAL REPORT FORMS

For Reporting Year -> 2002-2003

WLAP Permit No.--> LA-000141-01

Software and Version no.:-----> MS Excel 97 SR-2

Management Unit Summary Format

\begin{tabular}{|c|c|c|c|c|c|c|c|c|c|c|c|c|c|c|c|}
\hline & & & & (2) & & & & & & & & (10) & & & \\
\hline & & & & WW & (3) & & & & & & & COD & (11) & (12) & \\
\hline & & & & Applied & WW & (4) & (5) & (6) & & & (9) & Applied & COD & COD & \\
\hline & & & (1) & Non- & Applied & Suppl & $\mathrm{N}$ from & Fert & & (8) & Crop & Non- & Applied & Applied & (13) \\
\hline & Report- & Manage- & WW & Growing & Growing & Irrig W & WW & $\mathrm{N}$ & (7) & Crop & $\mathrm{N}$ & Growing & Growing & Yearly & $\mathrm{P}$ \\
\hline Permit & ing & ment & Applied & Season & Season & Applied & Applied & Applied & Crop & Yield & Removed & Season & Season & Ave & Applied \\
\hline No. & Year & Unit & MGA & $\mathrm{in} / \mathrm{ac} / \mathrm{yr}$ & $\mathrm{in} / \mathrm{ac} / \mathrm{yr}$ & $\mathrm{in} / \mathrm{ac} / \mathrm{yr}$ & $\mathrm{lb} / \mathrm{ac} / \mathrm{yr}$ & $1 \mathrm{~b} / \mathrm{ac} / \mathrm{yr}$ & Type & $\mathrm{lb} / \mathrm{ac} / \mathrm{yr}$ & $1 \mathrm{~b} / \mathrm{ac} / \mathrm{yr}$ & $1 \mathrm{~b} / \mathrm{ac} / \mathrm{d}$ & $1 \mathrm{~b} / \mathrm{ac} / \mathrm{d}$ & $1 \mathrm{~b} / \mathrm{ac} / \mathrm{d}$ & $\mathrm{lb} / \mathrm{ac} / \mathrm{yr}$ \\
\hline permitno & repyear & mangunit & wwapp & wwngs & wwgs & irrapp & napplied & fertnapp & croptype & cropyield & cnrem & codngs & codgs & codapp & phosapp \\
\hline LA-000141 & 2003 & MU-014101 & 5.98 & & & & 2.70 & & & & & & & 0.07 & 0.194 \\
\hline
\end{tabular}

(1) Total of twelve months WW loadings (million gallons per annum MGA).

(2) Non-growing season WW application.

(3) Growing season WW application.

(4) Growing season Irrigation water application

(5) Multiply total WW loading (in MG) by flow-weighted total constituent concentration (ppm); then multiply by 8.327 ; divide by acreage of management unit

(6) Multiply pounds of fertilizer applied by the nitrogen fertilizer guarentee number; then divide by 100 and divide again by acreage of management unit

(7) Crop type (e.g. wheat, corn). Use standard names provided in documentation

(8) Weight per acre of harvested portion of crop.

(9) multiply crop yield (converted to pounds/acre) by total nitrogen percent (from tissue test);

(10) Multiply NGS WW loading (MG) by flow-weighted constituent concentration (ppm); then multiply by 8.327 ; divide by acreage of management unit and number of NGS days

(11) Multiply GS WW loading (MG) by flow-weighted constituent concentration (ppm); then multiply by 8.327; divide by acreage of management unit and number of GS days

(12) Multiply total WW loading (MG) by flow-weighted constituent concentration (ppm); then multiply by 8.327 ; divide by acreage of management unit and 365 days

(13) See No (5)

All columns are formatted for the appropriate decimal places - do not modify.

Do not change any protected cell.

All units should be as noted below each column heading. 
Table A-4. Soils Worksheet from WLAP Data Entry for LA-141-1.XLS

\section{LAND APPLICATION OF WASTEWATER PROGRAM}

\section{ANNUAL REPORT FORMS}

For Reporting Year -> 2002-2003

WLAP Permit No.--> LA-000141-01

Software and Version no.:-----> MS Excel 97 SR-2

Soil Analyses

\begin{tabular}{|l|l|l|l|l|l|l|l|l|l|l|l|}
\hline & & depth & depth & Soil & organic & & & & EC & & Plant Avail \\
\hline Permit & Sample & top & bottom & Mon. & matter & Nitrate & Ammonia & & (umhos/ & pH & Phos \\
\hline No. & Date & (inches) & (inches) & Unit & $(\%)$ & (ppm) & (ppm) & SAR & cm) & (S.U.) & (ppm) \\
\hline permitno & smpldate & depthtop & depthbot & soilunit & ssom & ssnitrate & ssammonia & sssar & ssec & ssph & ssp_avail \\
\hline LA-000141 & $11 / 19 / 2003$ & 0 & 12 & SU-014101-5 & 1.15 & 4.03 & -4.07 & 6.20 & 1220 & 7.97 & 8.85 \\
\hline LA-000141 & $11 / 19 / 2003$ & 12 & 24 & SU-014101-5 & 0.62 & 1.06 & -4.00 & 9.12 & 1270 & 8.02 & -4.09 \\
\hline
\end{tabular}

1. If a parameter was analyzed but not detected, put the method detection limit (MDL) preceeded by a minus (-) sign. Contact your laboratory for the MDL if not known. 2. If a parameter was not analyzed, leave blank.

3. Make sure units for data entered are consistent with units specified in column headings.

4. For Date field, utilize date cell.

5. All columns are formatted for appropriate decimal places - do not modify.

6. Do not change any protected cell. You may add parameters on right hand side of spreadsheet if needed. You may hide columns that are not typically used. 
Table A-5. Wastewater Worksheet from WLAP Data Entry for LA-141-1.XLS

LAND APPLICATION OF WASTEWATER PROGRAM

ANNUAL REPORT FORMS

For Reporting Year -> 2002-2003

WLAP Permit No.--> LA-000141-01

Software and Version no.:-----> MS Excel 97 SR-2

Wastewater Quality Data

\begin{tabular}{|c|c|c|c|c|c|c|c|c|c|c|c|}
\hline & & Sampling & & total & & & total & & & fecal & nitrate+ \\
\hline Permit & Sample & Location & COD & coli & TKN & $\mathrm{pH}$ & phos & TSS & BOD & coli & nitrite \\
\hline No. & Date & (Station) & (ppm) & (count) & $(\mathrm{ppm})$ & (S.U.) & (ppm) & (ppm) & (ppm) & (count) & (ppm) \\
\hline permitno & smpldate & station & wwcod & wwtotalc & wwtkn & wwph & wwphostot & wwtss & wwbod & wwfecalc & wwnnn \\
\hline LA-000141 & $01 / 22 / 2003$ & WW-014101 & 196 & & 19.5 & 7.65 & & 28.3 & 49.7 & & 0.499 \\
\hline LA-000141 & $02 / 04 / 2003$ & WW-014101 & 147 & & 1.73 & 7.92 & & 95.7 & 51.2 & & 0.336 \\
\hline LA-000141 & $03 / 05 / 2003$ & WW-014101 & 93.3 & & 24.9 & 8.15 & & 55.9 & 54.6 & & 0.774 \\
\hline LA-000141 & $04 / 29 / 2003$ & WW-014101 & 94.9 & & 1.72 & 8.21 & & 39.9 & 27 & & 0.532 \\
\hline LA-000141 & $04 / 29 / 2003$ & WW-014101 & 110 & & 1.48 & & & 33 & 32.7 & & 0.429 \\
\hline LA-000141 & $05 / 28 / 2003$ & WW-014101 & 77.4 & & 12.8 & 7.7 & & 40.5 & 56.8 & & 1.22 \\
\hline LA-000141 & $06 / 19 / 2003$ & WW-014101 & 56.5 & & 12.3 & 7.62 & & 31.1 & 53.5 & & 0.642 \\
\hline LA-000141 & $07 / 30 / 2003$ & WW-014101 & 73.5 & & 10.3 & 7.66 & & 18.9 & 23 & & 0.979 \\
\hline LA-000141 & $08 / 20 / 2003$ & WW-014101 & 41.8 & & 11.6 & 7.95 & & 33.8 & 37.4 & & 0.409 \\
\hline LA-000141 & $09 / 24 / 2003$ & WW-014101 & 54.6 & & 5.13 & 7.76 & & 48.4 & 44.1 & & 0.765 \\
\hline LA-000141 & $10 / 14 / 2003$ & WW-014101 & 79.2 & & 17.7 & 7.75 & & 68.5 & 47.8 & & 0.354 \\
\hline LA-000141 & $11 / 04 / 2003$ & WW-014101 & 120 & & 14.6 & 7.82 & & 324 & 59.1 & & 0.479 \\
\hline LA-000141 & $12 / 10 / 2002$ & WW-014101 & 119 & & 18.2 & 7.92 & & 76 & 58.4 & & 0.42 \\
\hline LA-000141 & $06 / 18 / 2003$ & WW-014102 & & 8 & & & & & & 1 & \\
\hline LA-000141 & $06 / 19 / 2003$ & WW-014102 & 35.3 & & 1.81 & 9.89 & 0.316 & 6.5 & 4.35 & & 0.071 \\
\hline LA-000141 & $07 / 29 / 2003$ & WW-014102 & & & & 8.77 & & & & & \\
\hline LA-000141 & $07 / 30 / 2003$ & WW-014102 & 34.5 & & 4.25 & 9.49 & 0.408 & -4 & 2.14 & & 0.034 \\
\hline LA-000141 & $07 / 31 / 2003$ & WW-014102 & & 6 & & & & & & 1 & \\
\hline LA-000141 & $08 / 20 / 2003$ & WW-014102 & & 80 & & & & & & 29 & \\
\hline LA-000141 & $08 / 20 / 2003$ & WW-014102 & 40.1 & & 6.7 & 9.48 & 0.235 & -4 & 7.38 & & 0.012 \\
\hline LA-000141 & $09 / 24 / 2003$ & WW-014102 & 41.6 & & 2.9 & 9.56 & 0.213 & -4 & 3.15 & & 0.012 \\
\hline LA-000141 & $09 / 25 / 2003$ & WW-014102 & & 1 & & & & & & 1 & \\
\hline
\end{tabular}


Table A-5. (continued).

Wastewater Quality Data

1. If a parameter was analyzed but not detected, put the method detection limit (MDL) preceeded by a minus (-) sign.. Contact your laboratory for the MDL if it is not known.

2. If a parameter was not analyzed, leave blank.

3. Make sure units for data entered are consistent with units specified in column headings.

4. Bacteria are plate counts; $\mathrm{pH}$ in standard units; sp cond in umhos $/ \mathrm{cm}$; gross alpha \& beta in $\mathrm{pCi} / \mathrm{L}$.

5. Note also that alkalinity should be expressed as $\mathrm{CaCO} 3$.

6. For Date field, utilize a date cell.

7. All columns are formatted for appropriate decimal places - do not modify.

8. Do not change any protected cell. You may add parameter on right hand side of spreadsheet if needed.

9. You may hide columns that are not typically used. 
Table A-6. Site Summary Worksheet from WLAP Data Entry for LA-141-1.XLS

LAND APPLICATION OF WASTEWATER PROGRAM

ANNUAL REPORT FORMS

For Reporting Year -> 2002-2003

WLAP Permit No.--> LA-000141-01

Software and Version no.:-----> MS Excel 97 SR-2

Permitted Site Summary

\begin{tabular}{|l|l|l|l|}
\hline & & & $(2)$ \\
\hline & & $(1)$ & WW \\
\hline & Report- & WW & Application \\
\hline Permit & ing & Applied & Season \\
\hline No. & Year & MGA & (days) \\
\hline permitno & repyear & wwgen & Wwgenday \\
\hline LA-000141 & 2003 & 5.98 & 102 \\
\hline
\end{tabular}

(1) Total WW applied in million gallons per annum (MGA).

(2) Length of wastewater application season.

1. There should only be one entry for each permit number on this spreadsheet.

2. Make sure units for data entered are consistent with units specified in column headings.

3. All columns are formatted for the appropriate decimal places - do not modify.

4. Do not change any protected cell. 


\section{Appendix B}

Idaho Nuclear Technology and Engineering Center New Percolation Ponds Daily Effluent Flow Readings and Electronic Data Files 
B-2 


\section{Appendix B}

\section{Idaho Nuclear Technology and Engineering Center New Percolation Ponds Daily Effluent Flow Readings and Electronic Data Files}

Table B-1. Idaho Nuclear Technology and Engineering Center New Percolation Ponds daily effluent flows.

\begin{tabular}{|c|c|c|c|}
\hline Date & $\begin{array}{c}\text { Effluent } \\
\text { (WW-013001) } \\
\text { CPP-797 } \\
\left(\mathrm{gpd}^{\mathrm{a}}\right)\end{array}$ & Date & $\begin{array}{c}\text { Effluent } \\
\text { (WW-013001) } \\
\text { CPP-797 } \\
\left(\mathrm{gpd}^{\mathrm{a}}\right)\end{array}$ \\
\hline $11 / 1 / 2002$ & $1,489,600$ & $11 / 25 / 2002$ & $1,551,300$ \\
\hline $11 / 2 / 2002$ & $1,779,400$ & $11 / 26 / 2002$ & $1,559,600$ \\
\hline $11 / 3 / 2002$ & $1,818,000$ & $11 / 27 / 2002$ & $1,544,300$ \\
\hline $11 / 4 / 2002$ & $1,821,400$ & $11 / 28 / 2002$ & $1,545,900$ \\
\hline $11 / 5 / 2002$ & $1,806,300$ & $11 / 29 / 2002$ & $1,539,200$ \\
\hline $11 / 6 / 2002$ & $1,853,200$ & $11 / 30 / 2002$ & $1,526,100$ \\
\hline $11 / 7 / 2002$ & $1,819,700$ & $12 / 1 / 2002$ & $1,575,400$ \\
\hline $11 / 8 / 2002$ & $1,778,200$ & $12 / 2 / 2002$ & $1,595,400$ \\
\hline $11 / 9 / 2002$ & $1,707,300$ & $12 / 3 / 2002$ & $1,580,900$ \\
\hline $11 / 10 / 2002$ & $1,690,900$ & $12 / 4 / 2002$ & $1,573,400$ \\
\hline $11 / 11 / 2002$ & $1,630,200$ & $12 / 5 / 2002$ & $1,580,400$ \\
\hline $11 / 12 / 2002$ & $1,633,400$ & $12 / 6 / 2002$ & $1,553,200$ \\
\hline $11 / 13 / 2002$ & $1,636,600$ & $12 / 7 / 2002$ & $1,613,900$ \\
\hline $11 / 14 / 2002$ & $1,636,800$ & $12 / 8 / 2002$ & $1,625,200$ \\
\hline $11 / 15 / 2002$ & $1,606,800$ & $12 / 9 / 2002$ & $1,569,400$ \\
\hline $11 / 16 / 2002$ & $1,613,900$ & $12 / 10 / 2002$ & $1,564,600$ \\
\hline $11 / 17 / 2002$ & $1,618,100$ & $12 / 11 / 2002$ & $1,539,800$ \\
\hline $11 / 18 / 2002$ & $1,583,200$ & $12 / 12 / 2002$ & $1,524,100$ \\
\hline $11 / 19 / 2002$ & $1,611,600$ & $12 / 13 / 2002$ & $1,556,100$ \\
\hline $11 / 20 / 2002$ & $1,580,500$ & $12 / 14 / 2002$ & $1,554,300$ \\
\hline $11 / 21 / 2002$ & $1,596,100$ & $12 / 15 / 2002$ & $1,521,100$ \\
\hline $11 / 22 / 2002$ & $1,558,700$ & $12 / 16 / 2002$ & $1,534,000$ \\
\hline $11 / 23 / 2002$ & $1,579,200$ & $12 / 17 / 2002$ & $1,600,500$ \\
\hline $11 / 24 / 2002$ & $1,589,600$ & $12 / 18 / 2002$ & $1,601,100$ \\
\hline
\end{tabular}


Table B-1. (continued).

\begin{tabular}{|c|c|c|c|}
\hline Date & $\begin{array}{c}\text { Effluent } \\
\text { (WW-013001) } \\
\text { CPP-797 } \\
\left(\mathrm{gpd}^{\mathrm{a}}\right)\end{array}$ & Date & $\begin{array}{c}\text { Effluent } \\
\text { (WW-013001) } \\
\text { CPP-797 } \\
\left(\mathrm{gpd}^{\mathrm{a}}\right)\end{array}$ \\
\hline $12 / 19 / 2002$ & $1,572,200$ & $1 / 18 / 2003$ & $1,569,100$ \\
\hline $12 / 20 / 2002$ & $1,559,400$ & $1 / 19 / 2003$ & $1,562,800$ \\
\hline $12 / 21 / 2002$ & $1,511,500$ & $1 / 20 / 2003$ & $1,545,200$ \\
\hline $12 / 22 / 2002$ & $1,486,900$ & $1 / 21 / 2003$ & $1,532,500$ \\
\hline $12 / 23 / 2002$ & $1,488,400$ & $1 / 22 / 2003$ & $1,543,800$ \\
\hline $12 / 24 / 2002$ & $1,478,200$ & $1 / 23 / 2003$ & $1,544,600$ \\
\hline $12 / 25 / 2002$ & $1,512,800$ & $1 / 24 / 2003$ & $1,519,300$ \\
\hline $12 / 26 / 2002$ & $1,561,100$ & $1 / 25 / 2003$ & $1,532,800$ \\
\hline $12 / 27 / 2002$ & $1,550,900$ & $1 / 26 / 2003$ & $1,558,300$ \\
\hline $12 / 28 / 2002$ & $1,536,300$ & $1 / 27 / 2003$ & $1,536,800$ \\
\hline $12 / 29 / 2002$ & $1,554,800$ & $1 / 28 / 2003$ & $1,557,700$ \\
\hline $12 / 30 / 2002$ & $1,523,000$ & $1 / 29 / 2003$ & $1,526,000$ \\
\hline $12 / 31 / 2002$ & $1,558,500$ & $1 / 30 / 2003$ & $1,545,000$ \\
\hline $1 / 1 / 2003$ & $1,550,600$ & $1 / 31 / 2003$ & $1,525,500$ \\
\hline $1 / 2 / 2003$ & $1,574,900$ & $2 / 1 / 2003$ & $1,537,000$ \\
\hline $1 / 3 / 2003$ & $1,530,900$ & $2 / 2 / 2003$ & $1,515,000$ \\
\hline $1 / 4 / 2003$ & $1,531,000$ & $2 / 3 / 2003$ & $1,607,100$ \\
\hline $1 / 5 / 2003$ & $1,525,400$ & $2 / 4 / 2003$ & $1,551,100$ \\
\hline $1 / 6 / 2003$ & $1,605,600$ & $2 / 5 / 2003$ & $1,550,500$ \\
\hline $1 / 7 / 2003$ & $1,583,600$ & $2 / 6 / 2003$ & $1,556,900$ \\
\hline $1 / 8 / 2003$ & $1,564,600$ & $2 / 7 / 2003$ & $1,602,500$ \\
\hline $1 / 9 / 2003$ & $1,662,400$ & $2 / 8 / 2003$ & $1,611,400$ \\
\hline $1 / 10 / 2003$ & $1,570,400$ & $2 / 9 / 2003$ & $1,602,100$ \\
\hline $1 / 11 / 2003$ & $1,634,300$ & $2 / 10 / 2003$ & $1,578,800$ \\
\hline $1 / 12 / 2003$ & $1,576,300$ & $2 / 11 / 2003$ & $1,626,200$ \\
\hline $1 / 13 / 2003$ & $1,566,800$ & $2 / 12 / 2003$ & $1,588,400$ \\
\hline $1 / 14 / 2003$ & $1,568,700$ & $2 / 13 / 2003$ & $1,604,300$ \\
\hline $1 / 15 / 2003$ & $1,558,500$ & $2 / 14 / 2003$ & $1,626,000$ \\
\hline $1 / 16 / 2003$ & $1,544,800$ & $2 / 15 / 2003$ & $1,532,600$ \\
\hline $1 / 17 / 2003$ & $1,559,900$ & $2 / 16 / 2003$ & $1,526,600$ \\
\hline
\end{tabular}


Table B-1. (continued).

\begin{tabular}{|c|c|c|c|}
\hline Date & $\begin{array}{c}\text { Effluent } \\
\text { (WW-013001) } \\
\text { CPP-797 } \\
\left(\mathrm{gpd}^{\mathrm{a}}\right)\end{array}$ & Date & $\begin{array}{c}\text { Effluent } \\
\text { (WW-013001) } \\
\text { CPP-797 } \\
\left(\mathrm{gpd}^{\mathrm{a}}\right)\end{array}$ \\
\hline $2 / 17 / 2003$ & $1,552,100$ & $3 / 19 / 2003$ & $1,426,800$ \\
\hline $2 / 18 / 2003$ & $1,525,400$ & $3 / 20 / 2003$ & $1,394,800$ \\
\hline $2 / 19 / 2003$ & $1,531,300$ & $3 / 21 / 2003$ & $1,405,100$ \\
\hline $2 / 20 / 2003$ & $1,539,000$ & $3 / 22 / 2003$ & $1,416,100$ \\
\hline $2 / 21 / 2003$ & $1,469,000$ & $3 / 23 / 2003$ & $1,394,600$ \\
\hline $2 / 22 / 2003$ & $1,428,300$ & $3 / 24 / 2003$ & $1,419,200$ \\
\hline $2 / 23 / 2003$ & $1,422,000$ & $3 / 25 / 2003$ & $1,384,900$ \\
\hline $2 / 24 / 2003$ & $1,405,800$ & $3 / 26 / 2003$ & $1,398,600$ \\
\hline $2 / 25 / 2003$ & $1,522,500$ & $3 / 27 / 2003$ & $1,404,300$ \\
\hline $2 / 26 / 2003$ & $1,429,200$ & $3 / 28 / 2003$ & $1,376,700$ \\
\hline $2 / 27 / 2003$ & $1,400,200$ & $3 / 29 / 2003$ & $1,381,300$ \\
\hline $2 / 28 / 2003$ & $1,420,100$ & $3 / 30 / 2003$ & $1,382,800$ \\
\hline $3 / 1 / 2003$ & $1,401,700$ & $3 / 31 / 2003$ & $1,400,600$ \\
\hline $3 / 2 / 2003$ & $1,420,100$ & $4 / 1 / 2003$ & $1,406,100$ \\
\hline $3 / 3 / 2003$ & $1,451,900$ & $4 / 2 / 2003$ & $1,384,200$ \\
\hline $3 / 4 / 2003$ & $1,419,400$ & $4 / 3 / 2003$ & $1,409,200$ \\
\hline $3 / 5 / 2003$ & $1,436,000$ & $4 / 4 / 2003$ & $1,390,100$ \\
\hline $3 / 6 / 2003$ & $1,428,000$ & $4 / 5 / 2003$ & $1,367,600$ \\
\hline $3 / 7 / 2003$ & $1,447,700$ & $4 / 6 / 2003$ & $1,352,400$ \\
\hline $3 / 8 / 2003$ & $1,444,300$ & $4 / 7 / 2003$ & $1,407,900$ \\
\hline $3 / 9 / 2003$ & $1,435,200$ & $4 / 8 / 2003$ & $1,364,200$ \\
\hline $3 / 10 / 2003$ & $1,403,800$ & 4/9/2003 & $1,463,900$ \\
\hline $3 / 11 / 2003$ & $1,434,300$ & $4 / 10 / 2003$ & $1,485,000$ \\
\hline $3 / 12 / 2003$ & $1,397,300$ & $4 / 11 / 2003$ & $1,443,400$ \\
\hline $3 / 13 / 2003$ & $1,432,500$ & $4 / 12 / 2003$ & $1,444,600$ \\
\hline $3 / 14 / 2003$ & $1,404,500$ & $4 / 13 / 2003$ & $1,475,400$ \\
\hline $3 / 15 / 2003$ & $1,408,300$ & $4 / 14 / 2003$ & $1,436,000$ \\
\hline $3 / 16 / 2003$ & $1,442,700$ & $4 / 15 / 2003$ & $1,410,200$ \\
\hline $3 / 17 / 2003$ & $1,405,100$ & $4 / 16 / 2003$ & $1,362,200$ \\
\hline $3 / 18 / 2003$ & $1,389,100$ & $4 / 17 / 2003$ & $1,415,400$ \\
\hline
\end{tabular}


Table B-1. (continued).

\begin{tabular}{|c|c|c|c|}
\hline Date & $\begin{array}{c}\text { Effluent } \\
\text { (WW-013001) } \\
\text { CPP-797 } \\
\left(\mathrm{gpd}^{\mathrm{a}}\right)\end{array}$ & Date & $\begin{array}{c}\text { Effluent } \\
\text { (WW-013001) } \\
\text { CPP-797 } \\
\left(\mathrm{gpd}^{\mathrm{a}}\right)\end{array}$ \\
\hline $4 / 18 / 2003$ & $1,397,300$ & $5 / 18 / 2003$ & $1,257,600$ \\
\hline $4 / 19 / 2003$ & $1,378,600$ & $5 / 19 / 2003$ & $1,254,400$ \\
\hline $4 / 20 / 2003$ & $1,387,500$ & $5 / 20 / 2003$ & $1,258,600$ \\
\hline $4 / 21 / 2003$ & $1,382,500$ & $5 / 21 / 2003$ & $1,192,000$ \\
\hline $4 / 22 / 2003$ & $1,386,100$ & $5 / 22 / 2003$ & $1,281,300$ \\
\hline $4 / 23 / 2003$ & $1,411,100$ & $5 / 23 / 2003$ & $1,314,200$ \\
\hline $4 / 24 / 2003$ & $1,396,300$ & $5 / 24 / 2003$ & $1,348,000$ \\
\hline $4 / 25 / 2003$ & $1,373,500$ & $5 / 25 / 2003$ & $1,442,300$ \\
\hline $4 / 26 / 2003$ & $1,341,800$ & $5 / 26 / 2003$ & $1,392,000$ \\
\hline $4 / 27 / 2003$ & $1,346,300$ & $5 / 27 / 2003$ & $1,327,300$ \\
\hline $4 / 28 / 2003$ & $1,340,900$ & $5 / 28 / 2003$ & $1,281,500$ \\
\hline $4 / 29 / 2003$ & 763,200 & $5 / 29 / 2003$ & $1,388,700$ \\
\hline $4 / 30 / 2003$ & 912,400 & $5 / 30 / 2003$ & $1,439,000$ \\
\hline $5 / 1 / 2003$ & $1,308,800$ & $5 / 31 / 2003$ & $1,505,400$ \\
\hline $5 / 2 / 2003$ & $1,296,000$ & $6 / 1 / 2003$ & $1,431,100$ \\
\hline $5 / 3 / 2003$ & $1,294,800$ & $6 / 2 / 2003$ & $1,475,100$ \\
\hline $5 / 4 / 2003$ & $1,306,000$ & $6 / 3 / 2003$ & $1,469,400$ \\
\hline $5 / 5 / 2003$ & $1,293,700$ & $6 / 4 / 2003$ & $1,471,300$ \\
\hline $5 / 6 / 2003$ & $1,293,100$ & $6 / 5 / 2003$ & $1,434,300$ \\
\hline $5 / 7 / 2003$ & $1,227,700$ & $6 / 6 / 2003$ & $1,435,200$ \\
\hline $5 / 8 / 2003$ & $1,188,700$ & $6 / 7 / 2003$ & $1,424,600$ \\
\hline $5 / 9 / 2003$ & $1,017,200$ & $6 / 8 / 2003$ & $1,292,000$ \\
\hline $5 / 10 / 2003$ & $1,206,400$ & $6 / 9 / 2003$ & $1,292,800$ \\
\hline $5 / 11 / 2003$ & $1,358,300$ & $6 / 10 / 2003$ & $1,413,000$ \\
\hline $5 / 12 / 2003$ & $1,155,000$ & $6 / 11 / 2003$ & $1,477,700$ \\
\hline $5 / 13 / 2003$ & $1,111,100$ & $6 / 12 / 2003$ & $1,489,300$ \\
\hline $5 / 14 / 2003$ & $1,112,800$ & $6 / 13 / 2003$ & $1,456,500$ \\
\hline $5 / 15 / 2003$ & $1,209,000$ & $6 / 14 / 2003$ & $1,413,100$ \\
\hline $5 / 16 / 2003$ & $1,305,800$ & $6 / 15 / 2003$ & $1,314,900$ \\
\hline $5 / 17 / 2003$ & $1,261,200$ & $6 / 16 / 2003$ & $1,240,900$ \\
\hline
\end{tabular}


Table B-1. (continued).

\begin{tabular}{|c|c|c|c|}
\hline Date & $\begin{array}{c}\text { Effluent } \\
\text { (WW-013001) } \\
\text { CPP-797 } \\
\left(\mathrm{gpd}^{\mathrm{a}}\right)\end{array}$ & Date & $\begin{array}{c}\text { Effluent } \\
\text { (WW-013001) } \\
\text { CPP-797 } \\
\left(\mathrm{gpd}^{\mathrm{a}}\right)\end{array}$ \\
\hline $6 / 17 / 2003$ & $1,283,300$ & $7 / 17 / 2003$ & $1,524,700$ \\
\hline $6 / 18 / 2003$ & $1,469,000$ & $7 / 18 / 2003$ & $1,457,300$ \\
\hline $6 / 19 / 2003$ & $1,451,600$ & $7 / 19 / 2003$ & $1,454,100$ \\
\hline $6 / 20 / 2003$ & $1,492,100$ & $7 / 20 / 2003$ & $1,471,900$ \\
\hline $6 / 21 / 2003$ & $1,527,300$ & $7 / 21 / 2003$ & $1,470,300$ \\
\hline $6 / 22 / 2003$ & $1,488,000$ & $7 / 22 / 2003$ & $1,534,400$ \\
\hline $6 / 23 / 2003$ & $1,431,300$ & $7 / 23 / 2003$ & $1,490,400$ \\
\hline $6 / 24 / 2003$ & $1,441,600$ & $7 / 24 / 2003$ & $1,507,100$ \\
\hline $6 / 25 / 2003$ & $1,430,000$ & $7 / 25 / 2003$ & $1,401,200$ \\
\hline $6 / 26 / 2003$ & $1,367,000$ & $7 / 26 / 2003$ & $1,316,100$ \\
\hline $6 / 27 / 2003$ & $1,352,400$ & $7 / 27 / 2003$ & $1,323,400$ \\
\hline $6 / 28 / 2003$ & $1,508,800$ & $7 / 28 / 2003$ & $1,373,900$ \\
\hline $6 / 29 / 2003$ & $1,552,400$ & $7 / 29 / 2003$ & $1,335,900$ \\
\hline $6 / 30 / 2003$ & $1,538,800$ & $7 / 30 / 2003$ & $1,287,200$ \\
\hline $7 / 1 / 2003$ & $1,503,500$ & $7 / 31 / 2003$ & $1,308,400$ \\
\hline $7 / 2 / 2003$ & $1,519,800$ & $8 / 1 / 2003^{b}$ & $1,280,500$ \\
\hline $7 / 3 / 2003$ & $1,536,400$ & $8 / 2 / 2003$ & $1,273,100$ \\
\hline $7 / 4 / 2003$ & $1,553,500$ & $8 / 3 / 2003$ & $1,218,700$ \\
\hline $7 / 5 / 2003$ & $1,530,100$ & $8 / 4 / 2003$ & $1,180,500$ \\
\hline $7 / 6 / 2003$ & $1,562,400$ & $8 / 5 / 2003$ & $1,187,800$ \\
\hline $7 / 7 / 2003$ & $1,440,500$ & $8 / 6 / 2003$ & $1,025,900$ \\
\hline $7 / 8 / 2003$ & $1,406,600$ & $8 / 7 / 2003$ & $1,038,100$ \\
\hline $7 / 9 / 2003$ & $1,305,100$ & $8 / 8 / 2003$ & $1,060,800$ \\
\hline $7 / 10 / 2003$ & $1,333,200$ & $8 / 9 / 2003$ & $1,053,700$ \\
\hline $7 / 11 / 2003$ & $1,324,800$ & $8 / 10 / 2003$ & $1,040,000$ \\
\hline $7 / 12 / 2003$ & $1,495,400$ & $8 / 11 / 2003$ & $1,024,300$ \\
\hline $7 / 13 / 2003$ & $1,510,600$ & $8 / 12 / 2003$ & $1,040,600$ \\
\hline $7 / 14 / 2003$ & $1,506,400$ & $8 / 13 / 2003$ & $1,249,900$ \\
\hline $7 / 15 / 2003$ & $1,485,600$ & $8 / 14 / 2003$ & $1,125,600$ \\
\hline $7 / 16 / 2003$ & $1,449,000$ & $8 / 15 / 2003$ & $1,207,900$ \\
\hline
\end{tabular}


Table B-1. (continued).

\begin{tabular}{|c|c|c|c|}
\hline Date & $\begin{array}{c}\text { Effluent } \\
\text { (WW-013001) } \\
\text { CPP-797 } \\
\left(\mathrm{gpd}^{\mathrm{a}}\right)\end{array}$ & Date & $\begin{array}{c}\text { Effluent } \\
\text { (WW-013001) } \\
\text { CPP-797 } \\
\left(\mathrm{gpd}^{\mathrm{a}}\right)\end{array}$ \\
\hline $8 / 16 / 2003$ & $1,157,200$ & $9 / 15 / 2003$ & $1,066,600$ \\
\hline $8 / 17 / 2003$ & $1,093,200$ & $9 / 16 / 2003$ & $1,128,900$ \\
\hline $8 / 18 / 2003$ & 996,600 & $9 / 17 / 2003$ & $1,076,100$ \\
\hline $8 / 19 / 2003$ & $1,082,300$ & $9 / 18 / 2003$ & $1,098,100$ \\
\hline $8 / 20 / 2003$ & $1,190,800$ & $9 / 19 / 2003$ & $1,111,900$ \\
\hline $8 / 21 / 2003$ & $1,156,400$ & $9 / 20 / 2003$ & $1,085,700$ \\
\hline $8 / 22 / 2003$ & $1,166,700$ & $9 / 21 / 2003$ & $1,080,900$ \\
\hline $8 / 23 / 2003$ & $1,161,300$ & $9 / 22 / 2003$ & $1,067,100$ \\
\hline $8 / 24 / 2003$ & $1,062,300$ & $9 / 23 / 2003$ & $1,049,100$ \\
\hline $8 / 25 / 2003$ & $1,058,700$ & $9 / 24 / 2003$ & $1,049,400$ \\
\hline $8 / 26 / 2003$ & $1,063,300$ & $9 / 25 / 2003$ & $1,078,000$ \\
\hline $8 / 27 / 2003$ & $1,051,000$ & $9 / 26 / 2003$ & $1,102,900$ \\
\hline $8 / 28 / 2003$ & 663,400 & $9 / 27 / 2003$ & $1,083,700$ \\
\hline $8 / 29 / 2003$ & 833,900 & $9 / 28 / 2003$ & $1,100,300$ \\
\hline $8 / 30 / 2003$ & 910,900 & $9 / 29 / 2003$ & $1,070,900$ \\
\hline $8 / 31 / 2003$ & 920,600 & $9 / 30 / 2003$ & $1,127,300$ \\
\hline $9 / 1 / 2003$ & 921,800 & $10 / 1 / 2003$ & $1,118,800$ \\
\hline $9 / 2 / 2003$ & 909,200 & $10 / 2 / 2003$ & $1,186,700$ \\
\hline $9 / 3 / 2003$ & 903,200 & $10 / 3 / 2003$ & $1,228,364$ \\
\hline $9 / 4 / 2003$ & 947,700 & $10 / 4 / 2003$ & $1,218,000$ \\
\hline $9 / 5 / 2003$ & 927,800 & $10 / 5 / 2003$ & $1,216,500$ \\
\hline $9 / 6 / 2003$ & 925,300 & $10 / 6 / 2003$ & $1,219,500$ \\
\hline $9 / 7 / 2003$ & 903,900 & $10 / 7 / 2003$ & $1,237,800$ \\
\hline $9 / 8 / 2003$ & 932,000 & $10 / 8 / 2003$ & $1,244,800$ \\
\hline $9 / 9 / 2003$ & 888,200 & $10 / 9 / 2003$ & $1,288,600$ \\
\hline $9 / 10 / 2003$ & 869,800 & $10 / 10 / 2003$ & $1,299,100$ \\
\hline $9 / 11 / 2003$ & 863,000 & $10 / 11 / 2003$ & $1,275,500$ \\
\hline $9 / 12 / 2003$ & $1,063,400$ & $10 / 12 / 2003$ & $1,276,000$ \\
\hline $9 / 13 / 2003$ & $1,056,200$ & $10 / 13 / 2003$ & $1,254,000$ \\
\hline $9 / 14 / 2003$ & $1,083,400$ & $10 / 14 / 2003$ & $1,272,700$ \\
\hline
\end{tabular}


Table B-1. (continued).

\begin{tabular}{cc|cc}
\hline & $\begin{array}{c}\text { Effluent } \\
(\text { WW-013001) } \\
\text { CPP-797 } \\
\left(\text { gpd }^{\mathrm{a}}\right)\end{array}$ & Date & $\begin{array}{c}\text { Effluent } \\
(\text { WW-013001) } \\
\text { CPP-797 } \\
\left(\mathrm{gpd}^{\mathrm{a}}\right)\end{array}$ \\
\hline $10 / 15 / 2003$ & $1,259,300$ & $10 / 24 / 2003$ & 766,200 \\
$10 / 16 / 2003$ & $1,047,200$ & $10 / 25 / 2003$ & 954,340 \\
$10 / 17 / 2003$ & $1,219,200$ & $10 / 26 / 2003$ & $1,201,200$ \\
$10 / 18 / 2003$ & $1,202,600$ & $10 / 27 / 2003$ & $1,227,000$ \\
$10 / 19 / 2003$ & $1,144,800$ & $10 / 28 / 2003$ & $1,105,780$ \\
$10 / 20 / 2003$ & $1,160,100$ & $10 / 29 / 2003$ & 959,170 \\
$10 / 21 / 2003$ & $1,024,340$ & $10 / 30 / 2003$ & $1,071,790$ \\
$10 / 22 / 2003$ & $1,019,650$ & $10 / 31 / 2003$ & $1,189,650$ \\
$10 / 23 / 2003$ & 882,140 & & \\
\hline
\end{tabular}

a. gpd-Gallons per day.

b. On August 1, 2003, the discharge was switched from the south pond to the north pond. 
The following tables (Tables B-2 through B-5) represent hardcopies of the electronic WLAP data files required by the DEQ (DEQ 2002a). Section 5, "Electronic Data Entry," of DEQ 2002a, states "assemble data tables (electronic tables) with other parts of the annual report." The following tables were first compiled as worksheets within the WLAP Data Entry for LA-130-3.xls file using Microsoft Excel 97. The individual worksheets were saved as text files and incorporated as tables in this appendix. Other than formatting to fit the page, and tabulating the data columns, no other formatting was performed. Columns for those parameters not required by the permit are not included in the tables, nor are rejected results shown in these data tables. 
Table B-2. Hydraulic Worksheet from WLAP Data Entry for LA-130-3.XLS

LAND APPLICATION OF WASTEWATER PROGRAM

ANNUAL REPORT FORMS

For Reporting Year -> 2002-2003

WLAP Permit No.--> LA-000130-03

Software and Version no.:-----> MS Excel 97 SR-2

HYDRAULIC APPLICATION RATE

\begin{tabular}{|l|l|l|l|l|}
\hline & & & & Suppl \\
\hline & Month & Manage- & WW & Irrig W \\
\hline Permit & (use 15th & ment & Applied & Applied \\
\hline No. & as date) & Unit & (MG) & (MG) \\
\hline permitno & month & mangunit & wwapp & irrwapp \\
\hline LA-000130 & $11 / 15 / 2002$ & MU-013003 & 49.31 & \\
\hline LA-000130 & $12 / 15 / 2002$ & MU-013003 & 48.16 & \\
\hline LA-000130 & $01 / 15 / 2003$ & MU-013003 & 48.31 & \\
\hline LA-000130 & $02 / 15 / 2003$ & MU-013003 & 42.86 & \\
\hline LA-000130 & $03 / 15 / 2003$ & MU-013003 & 43.79 & \\
\hline LA-000130 & $04 / 15 / 2003$ & MU-013003 & 40.84 & \\
\hline LA-000130 & $05 / 15 / 2003$ & MU-013003 & 39.63 & \\
\hline LA-000130 & $06 / 15 / 2003$ & MU-013003 & 42.86 & \\
\hline LA-000130 & $07 / 15 / 2003$ & MU-013003 & 44.72 & \\
\hline LA-000130 & $11 / 15 / 2002$ & MU-013003 & 49.31 & \\
\hline LA-000130 & $12 / 15 / 2002$ & MU-013003 & 48.16 & \\
\hline LA-000130 & $08 / 15 / 2003$ & MU-013004 & 33.58 & \\
\hline LA-000130 & $09 / 15 / 2003$ & MU-013004 & 30.57 & \\
\hline LA-000130 & $10 / 15 / 2003$ & MU-013004 & 35.77 & \\
\hline
\end{tabular}

Note: 1. Dates here denote each month of the year.

2. These dates by convention shall be the 15 th of the month.

3. Each twelve month cycle is repeated for each management unit.

4. If the management unit was not used for land application, enter all zeros.

5. For monthly date, use date function.

6 . Do not change any protected cell.

3. Make sure units for data entered are consistent with units specified in column headings. 
Table B-3. Groundwater Worksheet from WLAP Data Entry for LA-130-3.XLS

LAND APPLICATION OF WASTEWATER PROGRAM

ANNUAL REPORT FORMS

For Reporting Year -> 2002-2003

WLAP Permit No.--> LA-000130-03

Software and Version no.:-----> MS Excel 97 SR-2

Ground Water Quality Data

\begin{tabular}{|c|c|c|c|c|c|c|c|c|c|c|c|c|c|}
\hline & & & & Static & & & & & & & & & \\
\hline & & & & Water & & & & & & & & & total \\
\hline Permit & Sample & Sampling & Well & Level & chloride & nitrate & $\mathrm{pH}$ & $\mathrm{Fe}$ & $\mathrm{Mn}$ & $\mathrm{Na}$ & TDS & fluoride & phos \\
\hline No. & Date & Station & ID & (feet) & (ppm) & (ppm) & (S.U.) & $(\mathrm{ppm})$ & $(\mathrm{ppm})$ & $(\mathrm{ppm})$ & $(\mathrm{ppm})$ & $(\mathrm{ppm})$ & $(\mathrm{ppm})$ \\
\hline permitno & smpldate & station & wellid & wtrdepth & chloride & nitrate & $\mathrm{ph}$ & irontotal & mangtotal & sodium & tds & fluoride & phostot \\
\hline LA-000130 & $4 / 14 / 2003$ & 03N 29E 26cab01 & GW-013005 & 495.53 & 12.5 & 0.48 & 8.46 & 3.92 & 0.0696 & 13.4 & 205 & 0.19 & 0.20 \\
\hline LA-000130 & $4 / 15 / 2003$ & 03N 29E 35bac01 & GW-013006 & 500.62 & 16.2 & 0.76 & 8.20 & 0.0613 & -0.0025 & 8.08 & 224 & 0.21 & 0.074 \\
\hline LA-000130 & $4 / 14 / 2003$ & 03N 29E 34aaa01 & GW-013007 & 505.13 & 6.8 & 0.26 & 8.06 & 0.217 & 0.0697 & 9.15 & 185 & 0.26 & -0.03 \\
\hline LA-000130 & $4 / 14 / 2003$ & 03N 29E 34aaa01 & GW-013007 & 505.13 & 13.6 & 0.23 & 8.06 & 0.238 & 0.0692 & 9.22 & 175 & 0.24 & 0.062 \\
\hline LA-000130 & $4 / 17 / 2003$ & 03N 29E 26cbd01 & GW-013009 & 117.85 & 91.4 & 0.82 & 8.04 & 1.240 & 0.0202 & 47.10 & 407 & 0.28 & 0.043 \\
\hline LA-000130 & $4 / 22 / 2003$ & 03N 29E 26cca01 & GW-013010 & 238.25 & 66.8 & 0.69 & 8.13 & 0.0631 & -0.0025 & 11.40 & 404 & 0.14 & 0.074 \\
\hline LA-000130 & $10 / 6 / 2003$ & 03N 29E 26cab01 & GW-013005 & 495.29 & 7.1 & 0.46 & 7.88 & 3.68 & 0.0681 & 13.9 & 203 & 0.11 & 0.31 \\
\hline LA-000130 & $10 / 6 / 2003$ & 03N 29E 26cab01 & GW-013005 & 495.29 & 7.2 & 0.43 & 7.88 & 4.13 & 0.0758 & 14.0 & 213 & 0.13 & 0.27 \\
\hline LA-000130 & $10 / 6 / 2003$ & 03N 29E 35bac01 & GW-013006 & 500.62 & 17.5 & 0.62 & 7.55 & 0.0655 & -0.0025 & 10.0 & 234 & 0.12 & -0.10 \\
\hline LA-000130 & $10 / 6 / 2003$ & 03N 29E 34aaa01 & GW-013007 & 506.48 & 6.8 & 0.14 & 7.52 & 0.939 & 0.072 & 9.75 & 178 & 0.14 & -0.10 \\
\hline LA-000130 & $10 / 7 / 2003$ & 03N 29E 26cbd01 & GW-013009 & 111.04 & 213 & 0.93 & 7.52 & 0.355 & 0.0054 & 134.0 & 554 & 0.39 & -0.10 \\
\hline LA-000130 & $10 / 7 / 2003$ & 03N 29E 26cca01 & GW-013010 & 234.94 & 112 & 0.84 & 7.56 & 0.147 & -0.0025 & 21.2 & 412 & 0.21 & -0.10 \\
\hline
\end{tabular}

\begin{tabular}{|c|c|c|c|c|c|c|c|c|c|c|c|c|c|}
\hline & & & & Static & & & & & & & & & \\
\hline & & & & Water & & & & & & & & & \\
\hline Permit & Sample & Sampling & Well & Level & TKN & $\mathrm{Hg}$ & nitrite & As & $\mathrm{Cd}$ & $\mathrm{Cr}$ & $\mathrm{Se}$ & $\mathrm{Ag}$ & $\mathrm{Cu}$ \\
\hline No. & Date & Station & ID & (feet) & (ppm) & $(\mathrm{ppm})$ & (ppm) & (ppm) & (ppm) & (ppm) & $(\mathrm{ppm})$ & (ppm) & (ppm) \\
\hline permitno & smpldate & Station & wellid & wtrdepth & tkn & mercury & nitrite & arsenic & cadmium & chromium & selinium & silver & copper \\
\hline LA-000130 & $4 / 14 / 2003$ & 03N 29E 26cab01 & GW-013005 & 495.53 & -0.90 & -0.0002 & -0.10 & 0.0026 & -0.001 & 0.0136 & -0.0025 & -0.0025 & 0.0157 \\
\hline LA-000130 & $4 / 15 / 2003$ & 03N 29E 35bac01 & GW-013006 & 500.62 & -1.8 & -0.0002 & -0.10 & -0.0025 & -0.001 & 0.0105 & -0.0025 & -0.0025 & -0.001 \\
\hline LA-000130 & $4 / 14 / 2003$ & 03N 29E 34aaa01 & GW-013007 & 505.13 & -0.90 & -0.0002 & -0.10 & -0.0025 & -0.001 & 0.0078 & -0.0025 & -0.0025 & -0.001 \\
\hline LA-000130 & $4 / 14 / 2003$ & 03N 29E 34aaa01 & GW-013007 & 505.13 & -0.90 & -0.0002 & -0.10 & -0.0025 & -0.001 & 0.0091 & -0.0025 & -0.0025 & -0.001 \\
\hline LA-000130 & $4 / 17 / 2003$ & 03N 29E 26cbd01 & GW-013009 & 117.85 & -1.8 & -0.0002 & -0.10 & 0.0029 & -0.001 & 0.0063 & -0.0025 & -0.0025 & 0.0026 \\
\hline LA-000130 & $4 / 22 / 2003$ & 03N 29E 26cca01 & GW-013010 & 238.25 & -1.8 & -0.0002 & -0.10 & -0.0025 & -0.001 & 0.0061 & -0.0025 & -0.0025 & 0.001 \\
\hline LA-000130 & $10 / 6 / 2003$ & 03N 29E 26cab01 & GW-013005 & 495.29 & -1.0 & -0.0002 & -0.10 & 0.0033 & -0.001 & 0.0147 & -0.0025 & -0.0025 & 0.0174 \\
\hline LA-000130 & $10 / 6 / 2003$ & 03N 29E 26cab01 & GW-013005 & 495.29 & -1.0 & -0.0002 & -0.10 & -0.0025 & -0.001 & 0.0186 & -0.0025 & -0.0025 & 0.0182 \\
\hline LA-000130 & $10 / 6 / 2003$ & 03N 29E 35bac01 & GW-013006 & 500.62 & -1.0 & -0.0002 & -0.10 & -0.0025 & -0.001 & 0.0084 & -0.0025 & -0.0025 & 0.0014 \\
\hline LA-000130 & $10 / 6 / 2003$ & 03N 29E 34aaa01 & GW-013007 & 506.48 & -1.0 & -0.0002 & -0.10 & -0.0025 & -0.001 & 0.0177 & -0.0025 & -0.0025 & 0.004 \\
\hline LA-000130 & $10 / 7 / 2003$ & $03 \mathrm{~N} 29 \mathrm{E} 26 \mathrm{cbd} 01$ & GW-013009 & 111.04 & -1.0 & -0.0002 & -0.10 & -0.0025 & -0.001 & 0.0075 & -0.0025 & -0.0025 & 0.0029 \\
\hline LA-000130 & $10 / 7 / 2003$ & 03N 29E 26cca01 & GW-013010 & 234.94 & -1.0 & -0.0002 & -0.10 & -0.0025 & -0.001 & 0.0066 & -0.0025 & -0.0025 & 0.001 \\
\hline
\end{tabular}


Table B-3. (continued).

Ground Water Quality Data

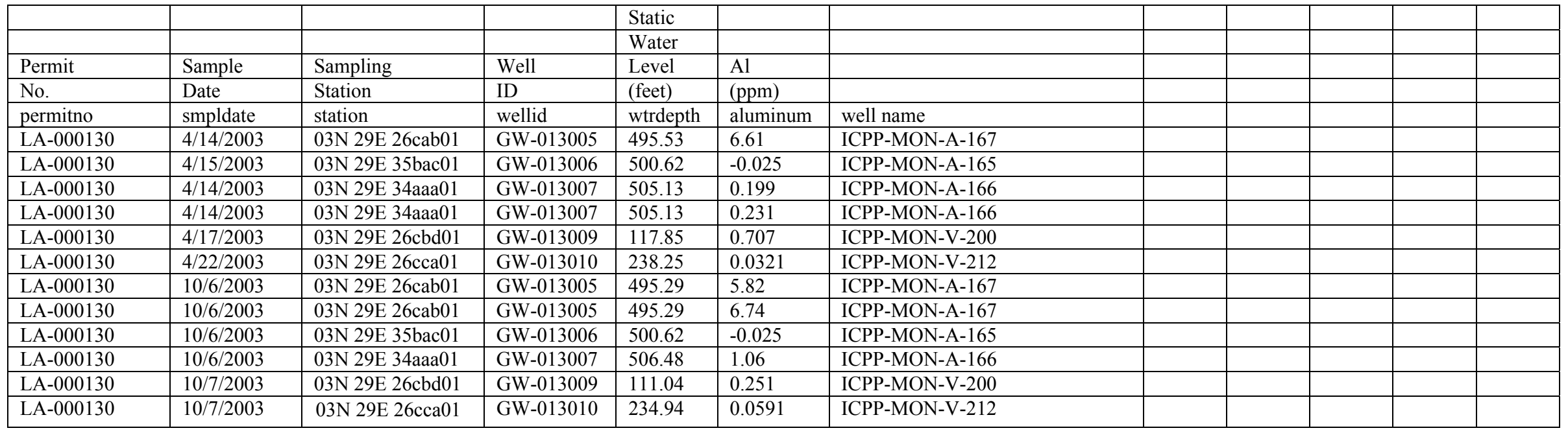

1. If a parameter was analyzed but not detected, put the method detection limit (MDL) preceeded by a minus (-) sign. Contact your laboratory for the MDL if not known.a -1.0

2. If a parameter was not analyzed, leave blank

3. Make sure units for data entered are consistent with units specified in column headings.

4. Bacteria are plate counts; $\mathrm{pH}$ in standard units; sp cond in umhos/cm; gross alpha \& beta in $\mathrm{pCi} / \mathrm{L}$.

5. Alkalinity should be expressed as $\mathrm{CaCO} 3$; static water level in feet.

6. For Date field, utilize date cell.

7. All columns are formated for appropriate decimal places- do not modify.

8. Sample methods are listed in the DEQ "Handbook for Land Application of Municipal and Industrial Wasteawter", April 1996, page IV-99-1 through 10.

Do not change any protected cell. You may add parameters on right hand side of spreadsheet if needed. You may hide columns that are not typically used 
Table B-4. Wastewater Worksheet from WLAP Data Entry for LA-130-3.XLS

LAND APPLICATION OF WASTEWATER PROGRAM

ANNUAL REPORT FORMS

For Reporting Year -> 2002-2003

WLAP Permit No.--> LA-000130-03

Software and Version no.:-----> MS Excel 97 SR-2

Wastewater Quality Data

\begin{tabular}{|c|c|c|c|c|c|c|c|c|c|c|c|c|}
\hline & & Sampling & & & & & & total & & & & \\
\hline Permit & Sample & Location & chloride & nitrate & TKN & pH_grab & $\mathrm{Na}$ & phos & TDS & fluoride & $\mathrm{Fe}$ & $\mathrm{Mn}$ \\
\hline No. & Date & (Station) & (ppm) & (ppm) & (ppm) & & (ppm) & (ppm) & (ppm) & (ppm) & (ppm) & (ppm) \\
\hline permitno & smpldate & station & wwchloride & wwnitrate & wwtkn & wwphgrb & wwsodium & wwphostot & wwtds & wwflride & wwiron & wwmn \\
\hline LA-000130 & $\frac{1}{11 / 04 / 2002}$ & WW-013001 & 76.1 & 0.89 & -0.24 & 8.1 & 64.1 & 0.0231 & 338 & 0.2 & -0.0161 & 0.0008 \\
\hline LA-000130 & $12 / 02 / 2002$ & WW-013001 & 806 & 0.93 & -0.24 & 7.9 & 95.8 & 0.0684 & 1265 & 0.16 & 0.278 & 0.0032 \\
\hline LA-000130 & $01 / 07 / 2003$ & WW-013001 & 647 & 0.53 & -0.24 & 7.9 & 351 & 0.0276 & 1210 & 0.12 & -0.0132 & 0.0005 \\
\hline LA-000130 & $01 / 07 / 2003$ & WW-013001 & & & & 7.9 & & & & & & \\
\hline LA-000130 & $02 / 10 / 2003$ & WW-013001 & 15.9 & 0.89 & -0.19 & 8 & 39.2 & 0.0219 & 243 & -0.01 & 0.0111 & 0.0005 \\
\hline LA-000130 & $03 / 17 / 2003$ & WW-013001 & 17.2 & 0.91 & -0.19 & 8 & 43.1 & 0.0271 & 242 & 0.16 & 0.0302 & 0.0009 \\
\hline LA-000130 & $04 / 08 / 2003$ & WW-013001 & 72.7 & 1 & -0.19 & 7.5 & 46.8 & 0.0243 & 327 & 0.21 & 0.0198 & 0.001 \\
\hline LA-000130 & $05 / 06 / 2003$ & WW-013001 & 67.3 & 0.96 & -0.19 & 8.1 & 69.6 & 0.0242 & 314 & 0.26 & -0.0107 & 0.0008 \\
\hline LA-000130 & $06 / 03 / 2003$ & WW-013001 & 139 & 0.93 & -0.19 & 8.3 & 57.6 & 0.0255 & 448 & 0.2 & 0.019 & 0.0007 \\
\hline LA-000130 & $07 / 14 / 2003$ & WW-013001 & 132 & 0.88 & -0.13 & 8.1 & 58.1 & 0.023 & 412 & 0.19 & 0.0141 & 0.0009 \\
\hline LA-000130 & $08 / 25 / 2003$ & WW-013001 & 278 & 0.99 & -0.13 & 8.2 & 172 & 0.02 & 671 & 0.21 & -0.0055 & -0.0003 \\
\hline LA-000130 & $09 / 08 / 2003$ & WW-013001 & 427 & 1 & -0.13 & 8.2 & 258 & 0.0282 & 893 & 0.19 & 0.0096 & 0.0005 \\
\hline LA-000130 & $10 / 27 / 2003$ & WW-013001 & 73.8 & 0.96 & -0.13 & 8.03 & 61.8 & 0.0295 & 330 & 0.2 & -0.0063 & -0.0003 \\
\hline & & Sampling & & & & & & & & & & \\
\hline Permit & Sample & Location & Arsenic & Chromium & Mercury & Selenium & Nitrite & Aluminum & Silver & Copper & Cadmium & \\
\hline No. & Date & (Station) & (ppm) & $(\mathrm{ppm})$ & (ppm) & (ppm) & (ppm) & (ppm) & (ppm) & $(\mathrm{ppm})$ & (ppm) & \\
\hline permitno & smpldate & station & wwarsenic & wwchromium & wwmercury & wwselenium & wwnitrite & wwalumin & wwsilver & wwcopper & wwcadmium & \\
\hline LA-000130 & $11 / 04 / 2002$ & WW-013001 & -0.0043 & 0.0057 & -0.00008 & -0.003 & -0.0061 & -0.0061 & -0.002 & 0.0043 & -0.0006 & \\
\hline LA-000130 & $12 / 02 / 2002$ & WW-013001 & -0.0049 & 0.0072 & -0.00008 & 0.0046 & -3 & 0.0198 & -0.003 & 0.0112 & -0.0006 & \\
\hline LA-000130 & $01 / 07 / 2003$ & WW-013001 & -0.004 & 0.0057 & -0.00008 & -0.0036 & -1.7 & -0.0054 & -0.0015 & 0.0036 & 0.0004 & \\
\hline LA-000130 & $01 / 07 / 2003$ & WW-013001 & & & & & & & & & & \\
\hline LA-000130 & $02 / 10 / 2003$ & WW-013001 & -0.004 & 0.0056 & -0.00008 & -0.0036 & -0.02 & -0.0054 & -0.0015 & 0.0022 & -0.0003 & \\
\hline LA-000130 & $03 / 17 / 2003$ & WW-013001 & -0.0043 & 0.006 & -0.00008 & -0.0039 & -0.017 & -0.0093 & -0.0017 & 0.0104 & -0.0004 & \\
\hline LA-000130 & $04 / 08 / 2003$ & WW-013001 & -0.0043 & 0.0058 & -0.00008 & -0.0039 & -0.0037 & -0.0093 & -0.0017 & 0.0046 & -0.0004 & \\
\hline LA-000130 & $05 / 06 / 2003$ & WW-013001 & -0.0043 & 0.0063 & -0.00008 & -0.0039 & -0.0037 & -0.0093 & -0.0017 & 0.0069 & -0.0004 & \\
\hline LA-000130 & $06 / 03 / 2003$ & WW-013001 & -0.0043 & 0.0063 & -0.00008 & -0.0037 & -0.0037 & -0.0107 & -0.0016 & 0.0019 & -0.0007 & \\
\hline LA-000130 & $07 / 14 / 2003$ & WW-013001 & -0.0035 & 0.006 & -0.00008 & -0.0038 & -0.0037 & 0.0121 & -0.0022 & 0.0025 & -0.0004 & \\
\hline LA-000130 & $08 / 25 / 2003$ & WW-013001 & -0.0043 & 0.0056 & -0.00008 & -0.0037 & -0.0037 & -0.0107 & -0.0016 & -0.0009 & -0.0007 & \\
\hline LA-000130 & $09 / 08 / 2003$ & WW-013001 & -0.0053 & 0.0058 & -0.00008 & -0.0035 & -0.0037 & -0.0073 & -0.0032 & 0.0033 & -0.0004 & \\
\hline LA-000130 & $10 / 27 / 2003$ & WW-013001 & -0.0047 & 0.006 & -0.00008 & -0.0049 & -0.0058 & -0.0077 & -0.0016 & 0.0026 & 0.0021 & \\
\hline
\end{tabular}


Table B-4. (continued).

Wastewater Quality Data

1. If a parameter was analyzed but not detected, put the method detection limit (MDL) preceeded by a minus (-) sign.. Contact your laboratory for the MDL if it is not known.

2. If a parameter was not analyzed, leave blank.

3. Make sure units for data entered are consistent with units specified in column headings.

4. Bacteria are plate counts; $\mathrm{pH}$ in standard units; sp cond in umhos $/ \mathrm{cm}$; gross alpha \& beta in $\mathrm{pCi} / \mathrm{L}$.

5. Note also that alkalinity should be expressed as $\mathrm{CaCO} 3$.

6. For Date field, utilize a date cell.

7. All columns are formatted for appropriate decimal places - do not modify.

8. Do not change any protected cell. You may add parameter on right hand side of spreadsheet if needed.

9. You may hide columns that are not typically used. 
Table B-5 Site Summary Worksheet from WLAP Data Entry for LA-130-3.XLS

LAND APPLICATION OF WASTEWATER PROGRAM

ANNUAL REPORT FORMS

For Reporting Year -> 2002-2003

WLAP Permit No.--> LA-000130-03

Software and Version no.:-----> MS Excel 97 SR-2

Permitted Site Summary

\begin{tabular}{|c|c|c|c|}
\hline & & & $(2)$ \\
\hline & & (1) & WW \\
\hline & Report- & WW & Application \\
\hline Permit & ing & Applied & Season \\
\hline No. & Year & MGA & (days) \\
\hline permitno & repyear & wwgen & wwgenday \\
\hline LA-000130 & 2003 & 500.38 & 365 \\
\hline
\end{tabular}

(1) Total WW applied in million gallons per annum (MGA).

(2) Length of wastewater application season.

1. There should only be one entry for each permit number on this spreadsheet.

2. Make sure units for data entered are consistent with units specified in column headings.

3. All columns are formatted for the appropriate decimal places - do not modify.

4. Do not change any protected cell. 


\section{Appendix C}

Idaho Nuclear Technology and Engineering Center Sewage Treatment Plant Influent and Effluent Flow Readings and Electronic Data Files 
C-2 


\section{Appendix C}

\section{Idaho Nuclear Technology and Engineering Center Sewage Treatment Plant Daily Influent and Effluent Flow Readings and Electronic Data Files}

Table C-1. Idaho Nuclear Technology and Engineering Center Sewage Treatment Plant daily influent and effluent flows.

\begin{tabular}{|c|c|c|c|c|c|}
\hline Date & $\begin{array}{c}\text { Influent } \\
\left(\begin{array}{c}\text { WW-011501) } \\
\left(\mathrm{gpd}^{\mathrm{a}}\right)\end{array}\right.\end{array}$ & 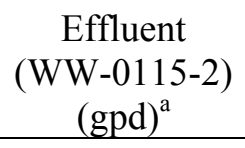 & Date & $\begin{array}{c}\text { Influent } \\
\left(\begin{array}{c}\text { WW-011501) } \\
\left(\mathrm{gpd}^{\mathrm{a}}\right)\end{array}\right. \\
\end{array}$ & $\begin{array}{c}\begin{array}{c}\text { Effluent } \\
(\mathrm{WW}-0115-2) \\
(\mathrm{gpd})^{\mathrm{a}}\end{array} \\
\end{array}$ \\
\hline $11 / 1 / 2002$ & $32,852^{b}$ & 19,954 & $11 / 25 / 2002$ & $40,227^{b}$ & 31,195 \\
\hline $11 / 2 / 2002$ & $32,852^{\mathrm{b}}$ & 19,954 & $11 / 26 / 2002$ & $57,647^{b}$ & 40,414 \\
\hline $11 / 3 / 2002$ & $41,560^{b}$ & 20,420 & $11 / 27 / 2002$ & $54,373^{b}$ & 40,263 \\
\hline $11 / 4 / 2002$ & $41,724^{b}$ & 21,168 & $11 / 28 / 2002$ & $50,409^{\mathrm{b}}$ & 41,315 \\
\hline $11 / 5 / 2002$ & $49,412^{b}$ & 28,227 & $11 / 29 / 2002$ & $41,722^{b}$ & 32,632 \\
\hline $11 / 6 / 2002$ & $51,757^{b}$ & 43,211 & $11 / 30 / 2002$ & $38,751^{b}$ & 29,606 \\
\hline $11 / 7 / 2002$ & $56,745^{\mathrm{b}}$ & 33,387 & $12 / 1 / 2002$ & $44,083^{b}$ & 32,916 \\
\hline $11 / 8 / 2002$ & $53,130^{\mathrm{b}}$ & 48,486 & $12 / 2 / 2002$ & $42,627^{b}$ & 29,757 \\
\hline $11 / 9 / 2002$ & $25,995^{\mathrm{b}}$ & 15,390 & $12 / 3 / 2002$ & $54,729^{b}$ & 37,926 \\
\hline $11 / 10 / 2002$ & $27,174^{b}$ & 20,215 & $12 / 4 / 2002$ & $55,870^{\mathrm{b}}$ & 40,552 \\
\hline $11 / 11 / 2002$ & $34,886^{\mathrm{b}}$ & 11,810 & $12 / 5 / 2002$ & $62,707^{b}$ & 44,760 \\
\hline $11 / 12 / 2002$ & $55,204^{\mathrm{b}}$ & 31,097 & $12 / 6 / 2002$ & $58,115^{\mathrm{b}}$ & 48,182 \\
\hline $11 / 13 / 2002$ & $54,033^{\mathrm{b}}$ & 32,422 & $12 / 7 / 2002$ & $35,265^{b}$ & 26,801 \\
\hline $11 / 14 / 2002$ & $53,167^{b}$ & 30,882 & $12 / 8 / 2002$ & $41,068^{\mathrm{b}}$ & 32,672 \\
\hline $11 / 15 / 2002$ & $53,523^{b}$ & 45,203 & $12 / 9 / 2002$ & $40,859^{\mathrm{b}}$ & 29,923 \\
\hline $11 / 16 / 2002$ & $42,015^{\mathrm{b}}$ & 39,433 & $12 / 10 / 2002$ & $59,895^{\mathrm{b}}$ & 42,295 \\
\hline $11 / 17 / 2002$ & $36,258^{b}$ & 31,863 & $12 / 11 / 2002$ & $54,966^{\mathrm{b}}$ & 44,248 \\
\hline $11 / 18 / 2002$ & $37,541^{b}$ & 29,971 & $12 / 12 / 2002$ & $77,914^{\mathrm{b}}$ & 43,097 \\
\hline $11 / 19 / 2002$ & $55,997^{b}$ & 44,107 & $12 / 13 / 2002$ & $\mathrm{NR}^{\mathrm{c}, \mathrm{d}}$ & 43,871 \\
\hline $11 / 20 / 2002$ & $52,770^{b}$ & 44,475 & $12 / 14 / 2002$ & $74,201^{\mathrm{b}}$ & 38,724 \\
\hline $11 / 21 / 2002$ & $53,306^{\mathrm{b}}$ & 43,708 & $12 / 15 / 2002$ & $20,688^{b}$ & 34,364 \\
\hline $11 / 22 / 2002$ & $45,208^{b}$ & 48,583 & $12 / 16 / 2002$ & $28,398^{\mathrm{b}}$ & 30,949 \\
\hline $11 / 23 / 2002$ & $41,790^{\mathrm{b}}$ & 34,903 & $12 / 17 / 2002$ & $52,467^{\mathrm{b}}$ & 46,309 \\
\hline $11 / 24 / 2002$ & $3,430^{\mathrm{b}}$ & 39,009 & $12 / 18 / 2002$ & $50,656^{\mathrm{b}}$ & 38,632 \\
\hline
\end{tabular}


Table C-1. (continued).

\begin{tabular}{|c|c|c|c|c|c|}
\hline Date & $\begin{array}{c}\text { Influent } \\
\left(\begin{array}{c}\text { WW-011501) } \\
\left(\mathrm{gpd}^{\mathrm{a}}\right)\end{array}\right.\end{array}$ & $\begin{array}{c}\text { Effluent } \\
(\text { WW-0115-2) } \\
(\mathrm{gpd})^{\mathrm{a}}\end{array}$ & Date & $\begin{array}{c}\text { Influent } \\
\left(\begin{array}{c}\text { WW-011501) } \\
\left(\mathrm{gpd}^{\mathrm{a}}\right)\end{array}\right.\end{array}$ & $\begin{array}{c}\begin{array}{c}\text { Effluent } \\
(\mathrm{WW}-0115-2) \\
(\mathrm{gpd})^{\mathrm{a}}\end{array}\end{array}$ \\
\hline $12 / 19 / 2002$ & $45,724^{\mathrm{b}}$ & 35,230 & $1 / 19 / 2003$ & $28,262^{\mathrm{b}}$ & 13,955 \\
\hline $12 / 20 / 2002$ & $42,923^{b}$ & 33,736 & $1 / 20 / 2003$ & $29,438^{b}$ & 15,227 \\
\hline $12 / 21 / 2002$ & $36,192^{b}$ & 26,157 & $1 / 21 / 2003$ & $47,707^{\mathrm{b}}$ & 25,356 \\
\hline $12 / 22 / 2002$ & $29,665^{\mathrm{b}}$ & 26,542 & $1 / 22 / 2003$ & $40,869^{b}$ & 29,332 \\
\hline $12 / 23 / 2002$ & $26,295^{\mathrm{b}}$ & 21,990 & $1 / 23 / 2003$ & $42,972^{b}$ & 25,225 \\
\hline $12 / 24 / 2002$ & $44,891^{\mathrm{b}}$ & 28,773 & $1 / 24 / 2003$ & $38,689^{\mathrm{b}}$ & 28,182 \\
\hline $12 / 25 / 2002$ & $29,475^{b}$ & 23,532 & $1 / 25 / 2003$ & $28,164^{b}$ & 19,705 \\
\hline $12 / 26 / 2002$ & $31,420^{\mathrm{b}}$ & 24,729 & $1 / 26 / 2003$ & $40,163^{b}$ & 21,906 \\
\hline $12 / 27 / 2002$ & $25,471^{b}$ & 25,537 & $1 / 27 / 2003$ & $39,167^{\mathrm{b}}$ & 23,279 \\
\hline $12 / 28 / 2002$ & $26,124^{b}$ & 27,903 & $1 / 28 / 2003$ & $44,383^{b}$ & 34,837 \\
\hline $12 / 29 / 2002$ & $26,871^{b}$ & 26,578 & $1 / 29 / 2003$ & $40,110^{\mathrm{b}}$ & 27,531 \\
\hline $12 / 30 / 2002$ & $26,100^{\mathrm{b}}$ & 24,616 & $1 / 30 / 2003$ & $46,938^{b}$ & 28,660 \\
\hline $12 / 31 / 2002$ & $22,364^{b}$ & 20,800 & $1 / 31 / 2003$ & $36,858^{\mathrm{b}}$ & 26,362 \\
\hline $1 / 1 / 2003$ & $27,182^{\mathrm{b}}$ & 26,615 & $2 / 1 / 2003$ & $33,789^{b}$ & 23,665 \\
\hline $1 / 2 / 2003$ & $30,036^{\mathrm{b}}$ & 24,720 & $2 / 2 / 2003$ & $29,511^{b}$ & 21,892 \\
\hline $1 / 3 / 2003$ & $32,309^{b}$ & 26,898 & $2 / 3 / 2003$ & $31,101^{b}$ & 17,006 \\
\hline $1 / 4 / 2003$ & $24,648^{\mathrm{b}}$ & 20,454 & $2 / 4 / 2003$ & $44,364^{\mathrm{b}}$ & 26,364 \\
\hline $1 / 5 / 2003$ & $32,958^{\mathrm{b}}$ & 26,441 & $2 / 5 / 2003$ & $43,014^{\mathrm{b}}$ & 25,751 \\
\hline $1 / 6 / 2003$ & $30,192^{b}$ & 21,938 & $2 / 6 / 2003$ & $50,487^{b}$ & 28,303 \\
\hline $1 / 7 / 2003$ & $53,140^{b}$ & 37,271 & $2 / 7 / 2003$ & $41,128^{b}$ & 27,605 \\
\hline $1 / 8 / 2003$ & $49,889^{b}$ & 38,101 & $2 / 8 / 2003$ & $24,058^{b}$ & 15,389 \\
\hline $1 / 9 / 2003$ & $48,568^{\mathrm{b}}$ & 39,893 & $2 / 9 / 2003$ & $33,221^{\mathrm{b}}$ & 19,824 \\
\hline $1 / 10 / 2003$ & $41,425^{\mathrm{b}}$ & 35,672 & $2 / 10 / 2003$ & $30,178^{b}$ & 18,672 \\
\hline $1 / 11 / 2003$ & $29,300^{\mathrm{b}}$ & 30,099 & $2 / 11 / 2003$ & $43,432^{b}$ & 28,616 \\
\hline $1 / 12 / 2003$ & $24,476^{\mathrm{b}}$ & 15,659 & $2 / 12 / 2003$ & $61,227^{\mathrm{b}}$ & 28,844 \\
\hline $1 / 13 / 2003$ & $21,567^{b}$ & 16,648 & $2 / 13 / 2003$ & 62,144 & 28,902 \\
\hline $1 / 14 / 2003$ & $47,233^{\mathrm{b}}$ & 26,180 & $2 / 14 / 2003$ & 60,121 & 36,633 \\
\hline $1 / 15 / 2003$ & $44,993^{\mathrm{b}}$ & 29,744 & $2 / 15 / 2003$ & 47,794 & 27,128 \\
\hline $1 / 16 / 2003$ & $49,942^{\mathrm{b}}$ & 29,253 & $2 / 16 / 2003$ & 43,892 & 22,332 \\
\hline $1 / 17 / 2003$ & $45,297^{\mathrm{b}}$ & 24,200 & $2 / 17 / 2003$ & 49,239 & 26,256 \\
\hline $1 / 18 / 2003$ & $18,106^{\mathrm{b}}$ & 24,732 & $2 / 18 / 2003$ & 60,316 & 30,467 \\
\hline
\end{tabular}


Table C-1. (continued).

\begin{tabular}{|c|c|c|c|c|c|}
\hline Date & $\begin{array}{c}\text { Influent } \\
\left(\begin{array}{c}\text { WW-011501) } \\
\left(\mathrm{gpd}^{\mathrm{a}}\right)\end{array}\right.\end{array}$ & 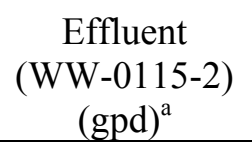 & Date & $\begin{array}{c}\text { Influent } \\
\left(\begin{array}{c}\text { WW-011501) } \\
\left(\mathrm{gpd}^{\mathrm{a}}\right)\end{array}\right.\end{array}$ & $\begin{array}{c}\text { Effluent } \\
(\mathrm{WW}-0115-2) \\
(\mathrm{gpd})^{\mathrm{a}}\end{array}$ \\
\hline $2 / 19 / 2003$ & 52,969 & 25,382 & $3 / 22 / 2003$ & 42,879 & 5,436 \\
\hline $2 / 20 / 2003$ & 56,954 & 26,448 & $3 / 23 / 2003$ & 54,430 & 10,033 \\
\hline $2 / 21 / 2003$ & 55,883 & 26,738 & $3 / 24 / 2003$ & 49,406 & 4,802 \\
\hline $2 / 22 / 2003$ & 39,549 & 19,039 & $3 / 25 / 2003$ & 62,927 & 13,260 \\
\hline $2 / 23 / 2003$ & 40,963 & 16,705 & $3 / 26 / 2003$ & 54,626 & 12,724 \\
\hline $2 / 24 / 2003$ & 28,129 & 10,949 & $3 / 27 / 2003$ & 56,830 & 11,847 \\
\hline $2 / 25 / 2003$ & 60,996 & 22,653 & $3 / 28 / 2003$ & 62,159 & 12,967 \\
\hline $2 / 26 / 2003$ & 44,533 & 21,714 & $3 / 29 / 2003$ & 45,867 & $2,300^{\mathrm{e}}$ \\
\hline $2 / 27 / 2003$ & 49,037 & 21,834 & $3 / 30 / 2003$ & 44,747 & $328^{\mathrm{e}}$ \\
\hline $2 / 28 / 2003$ & 45,661 & 22,248 & $3 / 31 / 2003$ & 44,933 & $664^{\mathrm{e}}$ \\
\hline $3 / 1 / 2003$ & 31,231 & 14,549 & $4 / 1 / 2003$ & 56,104 & $7,700^{\mathrm{e}}$ \\
\hline $3 / 2 / 2003$ & 30,054 & 12,344 & $4 / 2 / 2003$ & 58,945 & $13,901^{\mathrm{e}}$ \\
\hline $3 / 3 / 2003$ & 32,486 & 12,670 & $4 / 3 / 2003$ & 57,813 & $12,831^{\mathrm{e}}$ \\
\hline $3 / 4 / 2003$ & 53,112 & 21,673 & $4 / 4 / 2003$ & 57,337 & $9,040^{\mathrm{e}}$ \\
\hline $3 / 5 / 2003$ & 48,018 & 23,213 & $4 / 5 / 2003$ & 41,683 & $2,521^{\mathrm{e}}$ \\
\hline $3 / 6 / 2003$ & 47,334 & 21,882 & $4 / 6 / 2003$ & 41,562 & $772^{\mathrm{e}}$ \\
\hline $3 / 7 / 2003$ & 41,861 & 19,700 & $4 / 7 / 2003$ & 40,855 & $833^{\mathrm{e}}$ \\
\hline $3 / 8 / 2003$ & 34,984 & 16,362 & $4 / 8 / 2003$ & 51,216 & $7,220^{\mathrm{e}}$ \\
\hline $3 / 9 / 2003$ & 27,114 & 10,931 & 4/9/2003 & 50,403 & $8,239^{\mathrm{e}}$ \\
\hline $3 / 10 / 2003$ & 33,108 & 14,528 & $4 / 10 / 2003$ & 48,774 & $8,343^{\mathrm{e}}$ \\
\hline $3 / 11 / 2003$ & 56,056 & 23,362 & $4 / 11 / 2003$ & $\mathrm{NR}^{\mathrm{f}}$ & $6,379^{\mathrm{e}}$ \\
\hline $3 / 12 / 2003$ & 48,419 & 21,676 & $4 / 12 / 2003$ & $\mathrm{NR}^{\mathrm{f}}$ & $735^{\mathrm{e}}$ \\
\hline $3 / 13 / 2003$ & 48,705 & 20,841 & $4 / 13 / 2003$ & $\mathrm{NR}^{\mathrm{f}}$ & $84^{\mathrm{e}}$ \\
\hline $3 / 14 / 2003$ & 47,541 & 20,904 & $4 / 14 / 2003$ & $N^{f}$ & $769^{\mathrm{e}}$ \\
\hline $3 / 15 / 2003$ & 45,127 & 16,759 & $4 / 15 / 2003$ & 52,866 & $18,951^{\mathrm{e}}$ \\
\hline $3 / 16 / 2003$ & 43,557 & 17,015 & $4 / 16 / 2003$ & 47,281 & $18,828^{\mathrm{e}}$ \\
\hline $3 / 17 / 2003$ & 43,497 & 5,520 & $4 / 17 / 2003$ & 42,782 & $9,461^{\mathrm{e}}$ \\
\hline $3 / 18 / 2003$ & 61,500 & 11,785 & $4 / 18 / 2003$ & 45,243 & $10,904^{\mathrm{e}}$ \\
\hline $3 / 19 / 2003$ & 55,130 & 10,547 & $4 / 19 / 2003$ & 31,606 & $1,777^{\mathrm{e}}$ \\
\hline $3 / 20 / 2003$ & 59,294 & 13,543 & $4 / 20 / 2003$ & 26,042 & $214^{\mathrm{e}}$ \\
\hline $3 / 21 / 2003$ & 58,711 & 14,115 & $4 / 21 / 2003$ & 32,027 & $18^{\mathrm{e}}$ \\
\hline
\end{tabular}


Table C-1. (continued).

\begin{tabular}{|c|c|c|c|c|c|}
\hline Date & $\begin{array}{c}\text { Influent } \\
(\mathrm{WW-011501)} \\
\left(\mathrm{gpd}^{\mathrm{a}}\right)\end{array}$ & $\begin{array}{c}\text { Effluent } \\
(\text { WW-0115-2) } \\
(\text { gpd })^{\mathrm{a}}\end{array}$ & Date & $\begin{array}{c}\text { Influent } \\
(\mathrm{WW}-011501) \\
\left(\mathrm{gpd}^{\mathrm{a}}\right)\end{array}$ & 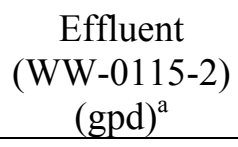 \\
\hline $4 / 22 / 2003$ & 30,247 & $1,129^{\mathrm{e}}$ & $5 / 23 / 2003$ & 23,644 & 12,412 \\
\hline $4 / 23 / 2003$ & $\mathrm{NR}^{\mathrm{g}}$ & $3,767^{\mathrm{e}}$ & $5 / 24 / 2003$ & $\mathrm{NR}^{\mathrm{h}}$ & 3,980 \\
\hline $4 / 24 / 2003$ & 33,086 & $12,916^{\mathrm{e}}$ & $5 / 25 / 2003$ & $\mathrm{NR}^{\mathrm{h}}$ & 611 \\
\hline $4 / 25 / 2003$ & 38,768 & $2,643^{\mathrm{e}}$ & $5 / 26 / 2003$ & $\mathrm{NR}^{\mathrm{h}}$ & 2,670 \\
\hline $4 / 26 / 2003$ & 14,239 & $465^{\mathrm{e}}$ & $5 / 27 / 2003$ & 33,762 & 667 \\
\hline $4 / 27 / 2003$ & 15,110 & $77^{\mathrm{e}}$ & $5 / 28 / 2003$ & 45,949 & 6,059 \\
\hline $4 / 28 / 2003$ & 17,244 & $\mathrm{NR}^{\mathrm{e}}$ & $5 / 29 / 2003$ & 53,491 & 19,804 \\
\hline $4 / 29 / 2003$ & 32,599 & $11,220^{\mathrm{e}}$ & $5 / 30 / 2003$ & 41,787 & 18,648 \\
\hline $4 / 30 / 2003$ & 36,476 & $10,654^{\mathrm{e}}$ & $5 / 31 / 2003$ & 29,308 & 4,971 \\
\hline $5 / 1 / 2003$ & 33,316 & $3,851^{\mathrm{e}}$ & $6 / 1 / 2003$ & 30,606 & 3,394 \\
\hline $5 / 2 / 2003$ & 29,506 & $2,876^{\mathrm{e}}$ & $6 / 2 / 2003$ & 30,077 & 3,629 \\
\hline $5 / 3 / 2003$ & 16,801 & $22,350^{\mathrm{e}}$ & $6 / 3 / 2003$ & 46,750 & 13,051 \\
\hline $5 / 4 / 2003$ & 14,074 & $1,683^{\mathrm{e}}$ & $6 / 4 / 2003$ & 50,895 & 22,537 \\
\hline $5 / 5 / 2003$ & 16,037 & $\mathrm{NR}^{\mathrm{e}}$ & $6 / 5 / 2003$ & 45,787 & 18,703 \\
\hline $5 / 6 / 2003$ & 34,061 & $3,753^{\mathrm{e}}$ & $6 / 6 / 2003$ & 47,222 & 24,249 \\
\hline $5 / 7 / 2003$ & 37,764 & $4,089^{\mathrm{e}}$ & $6 / 7 / 2003$ & 28,499 & 7,902 \\
\hline $5 / 8 / 2003$ & 31,075 & $1,258^{\mathrm{e}}$ & $6 / 8 / 2003$ & 30,541 & 5,931 \\
\hline $5 / 9 / 2003$ & 43,062 & $649^{e}$ & $6 / 9 / 2003$ & 32,559 & 8,572 \\
\hline $5 / 10 / 2003$ & 27,127 & $31^{\mathrm{e}}$ & $6 / 10 / 2003$ & 49,947 & 16,574 \\
\hline $5 / 11 / 2003$ & 34,103 & $\mathrm{NR}^{\mathrm{e}}$ & $6 / 11 / 2003$ & 53,902 & 17,910 \\
\hline $5 / 12 / 2003$ & 32,562 & $157^{\mathrm{e}}$ & $6 / 12 / 2003$ & 53,720 & 20,247 \\
\hline $5 / 13 / 2003$ & 40,456 & $837^{\mathrm{e}}$ & $6 / 13 / 2003$ & 59,175 & 32,204 \\
\hline $5 / 14 / 2003$ & 52,862 & $1,783^{\mathrm{e}}$ & $6 / 14 / 2003$ & 33,512 & 11,592 \\
\hline $5 / 15 / 2003$ & 45,208 & $1,386^{\mathrm{e}}$ & $6 / 15 / 2003$ & 30,660 & 5,201 \\
\hline $5 / 16 / 2003$ & 61,415 & $798^{\mathrm{e}}$ & $6 / 16 / 2003$ & 38,646 & 10,738 \\
\hline $5 / 17 / 2003$ & 25,923 & $3,900^{\mathrm{e}}$ & $6 / 17 / 2003$ & 58,876 & 24,265 \\
\hline $5 / 18 / 2003$ & 32,185 & $8,607^{\mathrm{e}}$ & $6 / 18 / 2003$ & 68,865 & 24,458 \\
\hline $5 / 19 / 2003$ & 30,262 & $1,852^{\mathrm{e}}$ & $6 / 19 / 2003$ & 79,739 & 22,856 \\
\hline $5 / 20 / 2003$ & 55,300 & $11,479^{\mathrm{e}}$ & $6 / 20 / 2003$ & 70,929 & 19,817 \\
\hline $5 / 21 / 2003$ & 30,386 & $69^{e}$ & $6 / 21 / 2003$ & 52,427 & 5,495 \\
\hline $5 / 22 / 2003$ & 39,079 & 13,168 & $6 / 22 / 2003$ & 56,307 & 2,553 \\
\hline
\end{tabular}


Table C-1. (continued).

\begin{tabular}{|c|c|c|c|c|c|}
\hline Date & $\begin{array}{c}\text { Influent } \\
\left(\begin{array}{c}\text { WW-011501) } \\
\left(\mathrm{gpd}^{\mathrm{a}}\right)\end{array}\right.\end{array}$ & 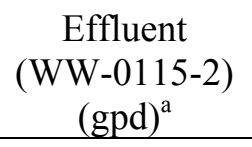 & Date & $\begin{array}{c}\text { Influent } \\
(\mathrm{WW}-011501) \\
\left(\mathrm{gpd}^{\mathrm{a}}\right)\end{array}$ & $\begin{array}{c}\text { Effluent } \\
(\text { WW-0115-2) } \\
(\mathrm{gpd})^{\mathrm{a}}\end{array}$ \\
\hline $6 / 23 / 2003$ & 47,768 & 4,428 & $7 / 24 / 2003$ & 53,995 & 26,727 \\
\hline $6 / 24 / 2003$ & 64,720 & 31,078 & $7 / 25 / 2003$ & 56,860 & 20,500 \\
\hline $6 / 25 / 2003$ & 50,565 & 30,429 & $7 / 26 / 2003$ & 45,373 & 13,669 \\
\hline $6 / 26 / 2003$ & 48,941 & 31,999 & $7 / 27 / 2003$ & 51,993 & 21,803 \\
\hline $6 / 27 / 2003$ & 42,112 & 25,550 & $7 / 28 / 2003$ & 47,678 & 14,585 \\
\hline $6 / 28 / 2003$ & 40,264 & 14,444 & $7 / 29 / 2003$ & 68,580 & 36,658 \\
\hline $6 / 29 / 2003$ & 38,569 & 11,124 & $7 / 30 / 2003$ & 62,600 & 35,569 \\
\hline $6 / 30 / 2003$ & 33,739 & 9,341 & $7 / 31 / 2003$ & 69,611 & 32,610 \\
\hline $7 / 1 / 2003$ & 49,279 & 17,301 & $8 / 1 / 2003$ & 50,891 & 25,881 \\
\hline $7 / 2 / 2003$ & 57,730 & 20,800 & $8 / 2 / 2003$ & $\mathrm{NR}^{\mathrm{i}}$ & $\mathrm{NR}^{\mathrm{i}}$ \\
\hline $7 / 3 / 2003$ & 48,499 & 18,053 & $8 / 3 / 2003$ & $\mathrm{NR}^{\mathrm{i}}$ & $\mathrm{NR}^{\mathrm{i}}$ \\
\hline $7 / 4 / 2003$ & 46,360 & 15,218 & $8 / 4 / 2003$ & $\mathrm{NR}^{\mathrm{i}}$ & $\mathrm{NR}^{\mathrm{i}}$ \\
\hline $7 / 5 / 2003$ & 43,011 & 12,360 & $8 / 5 / 2003$ & $\mathrm{NR}^{\mathrm{i}}$ & $\mathrm{NR}^{\mathrm{i}}$ \\
\hline $7 / 6 / 2003$ & 51,360 & 10,308 & $8 / 6 / 2003$ & $\mathrm{NR}^{\mathrm{i}}$ & 32,832 \\
\hline $7 / 7 / 2003$ & 45,122 & 9,296 & $8 / 7 / 2003$ & 60,250 & 24,381 \\
\hline $7 / 8 / 2003$ & 53,472 & 21,702 & $8 / 8 / 2003$ & 53,625 & 27,590 \\
\hline $7 / 9 / 2003$ & 51,153 & 13,547 & $8 / 9 / 2003$ & 38,421 & 15,587 \\
\hline $7 / 10 / 2003$ & 49,357 & 21,181 & $8 / 10 / 2003$ & 48,895 & 16,741 \\
\hline $7 / 11 / 2003$ & 50,378 & 23,737 & $8 / 11 / 2003$ & 43,473 & 14,123 \\
\hline $7 / 12 / 2003$ & 53,297 & 12,827 & $8 / 12 / 2003$ & 59,786 & 29,582 \\
\hline $7 / 13 / 2003$ & 32,882 & 7,018 & $8 / 13 / 2003$ & 55,287 & 30,257 \\
\hline $7 / 14 / 2003$ & 34,188 & 1,010 & $8 / 14 / 2003$ & 56,215 & 28,470 \\
\hline $7 / 15 / 2003$ & 47,573 & 17,403 & $8 / 15 / 2003$ & 57,996 & 33,188 \\
\hline $7 / 16 / 2003$ & 48,743 & 22,604 & $8 / 16 / 2003$ & 39,632 & 20,684 \\
\hline $7 / 17 / 2003$ & 49,314 & 18,678 & $8 / 17 / 2003$ & 39,178 & 10,012 \\
\hline $7 / 18 / 2003$ & 44,682 & 15,925 & $8 / 18 / 2003$ & 43,346 & 16,108 \\
\hline $7 / 19 / 2003$ & 26,900 & 9,865 & $8 / 19 / 2003$ & 55,243 & 31,822 \\
\hline $7 / 20 / 2003$ & 28,521 & 5,995 & $8 / 20 / 2003$ & 57,040 & 33,533 \\
\hline $7 / 21 / 2003$ & 32,398 & 4,089 & $8 / 21 / 2003$ & 58,918 & 30,628 \\
\hline $7 / 22 / 2003$ & 55,052 & 27,386 & $8 / 22 / 2003$ & 60,030 & 43,815 \\
\hline $7 / 23 / 2003$ & 56,147 & 27,399 & $8 / 23 / 2003$ & 45,632 & 28,369 \\
\hline
\end{tabular}


Table C-1. (continued).

\begin{tabular}{|c|c|c|c|c|c|}
\hline Date & $\begin{array}{c}\text { Influent } \\
\left(\begin{array}{c}\text { WW-011501) } \\
\left(\mathrm{gpd}^{\mathrm{a}}\right)\end{array}\right.\end{array}$ & 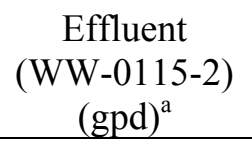 & Date & $\begin{array}{c}\text { Influent } \\
(\mathrm{WW}-011501) \\
\left(\mathrm{gpd}^{\mathrm{a}}\right)\end{array}$ & $\begin{array}{c}\text { Effluent } \\
(\text { WW-0115-2) } \\
(\mathrm{gpd})^{\mathrm{a}}\end{array}$ \\
\hline $8 / 24 / 2003$ & 41,787 & 21,019 & $9 / 24 / 2003$ & 45,104 & 19,127 \\
\hline $8 / 25 / 2003$ & 45,451 & 19,001 & $9 / 25 / 2003$ & 41,070 & 18,449 \\
\hline $8 / 26 / 2003$ & 67,747 & 43,808 & $9 / 26 / 2003$ & 39,631 & 18,293 \\
\hline $8 / 27 / 2003$ & 60,645 & 39,742 & $9 / 27 / 2003$ & 30,717 & 8,043 \\
\hline $8 / 28 / 2003$ & 61,245 & 35,180 & $9 / 28 / 2003$ & 24,067 & 5,107 \\
\hline $8 / 29 / 2003$ & 58,496 & 33,483 & $9 / 29 / 2003$ & 29,247 & 4,939 \\
\hline $8 / 30 / 2003$ & 38,297 & 22,897 & $9 / 30 / 2003$ & 48,683 & 19,265 \\
\hline $8 / 31 / 2003$ & 48,505 & 27,944 & $10 / 1 / 2003$ & 45,342 & 20,124 \\
\hline $9 / 1 / 2003$ & 34,564 & 25,462 & $10 / 2 / 2003$ & 41,487 & 21,260 \\
\hline $9 / 2 / 2003$ & 56,619 & 23,800 & $10 / 3 / 2003$ & $\mathrm{NR}^{\mathrm{j}}$ & 37,003 \\
\hline $9 / 3 / 2003$ & 54,990 & 37,921 & $10 / 4 / 2003$ & $\mathrm{NR}^{\mathrm{j}}$ & 5,462 \\
\hline $9 / 4 / 2003$ & 62,980 & 33,161 & $10 / 5 / 2003$ & $\mathrm{NR}^{\mathrm{j}}$ & 9,574 \\
\hline $9 / 5 / 2003$ & 57,423 & 32,238 & $10 / 6 / 2003$ & $\mathrm{NR}^{\mathrm{j}}$ & 10,125 \\
\hline $9 / 6 / 2003$ & 59,882 & 29,294 & $10 / 7 / 2003$ & $\mathrm{NR}^{\mathrm{j}}$ & 30,602 \\
\hline $9 / 7 / 2003$ & 52,936 & 46,954 & $10 / 8 / 2003$ & $\mathrm{NR}^{\mathrm{j}}$ & 32,892 \\
\hline $9 / 8 / 2003$ & 42,040 & 20,809 & $10 / 9 / 2003$ & $\mathrm{NR}^{\mathrm{j}}$ & 35,053 \\
\hline $9 / 9 / 2003$ & 50,878 & 24,832 & $10 / 10 / 2003$ & 40,275 & 31,913 \\
\hline $9 / 10 / 2003$ & 50,017 & 35,234 & $10 / 11 / 2003$ & 44,720 & 18,651 \\
\hline $9 / 11 / 2003$ & 56,163 & 36,985 & $10 / 12 / 2003$ & 41,208 & 15,981 \\
\hline $9 / 12 / 2003$ & 47,860 & 28,477 & $10 / 13 / 2003$ & 44,744 & 13,406 \\
\hline $9 / 13 / 2003$ & 31,312 & 9,327 & $10 / 14 / 2003$ & 60,670 & 34,506 \\
\hline $9 / 14 / 2003$ & 31,930 & 13,685 & $10 / 15 / 2003$ & 60,160 & 35,501 \\
\hline $9 / 15 / 2003$ & 34,804 & 17,062 & $10 / 16 / 2003$ & 56,489 & 30,993 \\
\hline $9 / 16 / 2003$ & 53,734 & 32,066 & $10 / 17 / 2003$ & 47,912 & 30,540 \\
\hline $9 / 17 / 2003$ & 49,080 & 27,063 & $10 / 18 / 2003$ & 36,301 & 16,086 \\
\hline $9 / 18 / 2003$ & 38,622 & 23,275 & $10 / 19 / 2003$ & 35,662 & 13,955 \\
\hline $9 / 19 / 2003$ & 35,398 & 22,299 & $10 / 20 / 2003$ & 38,617 & 12,682 \\
\hline $9 / 20 / 2003$ & 18,368 & 6,563 & $10 / 21 / 2003$ & 48,790 & 26,442 \\
\hline $9 / 21 / 2003$ & 21,805 & 4,829 & $10 / 22 / 2003$ & 50,146 & 28,392 \\
\hline $9 / 22 / 2003$ & 21,392 & 5,712 & $10 / 23 / 2003$ & 68,125 & 36,293 \\
\hline $9 / 23 / 2003$ & 51,193 & 23,047 & $10 / 24 / 2003$ & 64,314 & 35,172 \\
\hline
\end{tabular}


Table C-1. (continued).

\begin{tabular}{ccc|ccc}
\hline & $\begin{array}{c}\text { Influent } \\
(\mathrm{WW-011501)} \\
\left(\mathrm{gpd}^{\mathrm{a}}\right)\end{array}$ & $\begin{array}{c}\text { Effluent } \\
(\mathrm{WW-0115-2}) \\
(\mathrm{gpd})^{\mathrm{a}}\end{array}$ & Date & $\begin{array}{c}\text { Influent } \\
(\mathrm{WW-011501)} \\
\left(\mathrm{gpd}^{\mathrm{a}}\right)\end{array}$ & $\begin{array}{c}\text { Effluent } \\
(\mathrm{WW-0115-2}) \\
(\mathrm{gpd})^{\mathrm{a}}\end{array}$ \\
\hline $10 / 25 / 2003$ & 58,905 & 29,178 & $10 / 29 / 2003$ & 79,450 & 41,322 \\
$10 / 26 / 2003$ & 65,563 & 32,468 & $10 / 30 / 2003$ & 75,450 & 40,748 \\
$10 / 27 / 2003$ & 61,192 & 31,897 & $10 / 31 / 2003$ & 83,072 & 41,881 \\
$10 / 28 / 2003$ & 70,763 & 39,485 & & & \\
\hline
\end{tabular}

a. gpd-Gallons per day.

b. The south influent flow meter was out of service (OOS) from November 1, 2002, through February 12, 2003. Based on historical data and worst-case scenario calculations, the influent flow is estimated to be 68,514 gpd during November; 50,291 gpd during December; 52,583 during January; and 55,580 from February 1 through February 12.

c. NR-No flow reading available.

d. No influent reading was taken on December 13, 2002. Based on worst case scenario calculations, the influent flow is estimated to be is 53,860 gpd.

e. Effluent meter readings from March 29, 2003, through May 21, 2003 are suspect due to a leaking weir plate discharge valve. Based on historical data and worst-case scenario calculations, the effluent flow is estimated to be 29,157 gpd during this period.

f. No influent reading taken due to power outage. Based on worst case scenario calculations, the influent flow is estimated to be 43,381 gpd.

g. No influent reading taken due to work being performed on new power supply. Based on worst case scenario calculations, the influent flow is estimated to be 53,340 gpd.

h. No influent reading available due to the readings being incorrectly taking. Based on worst case scenario calculations, the influent flow is estimated to be 42,160 gpd for this period.

i. Flow meters were OOS due to a power outage. Based on historical data and worst-case scenario calculations, the influent flow is estimated to be 48,276 gpd during this period. Based on historical data and worst-case scenario calculations, the effluent flow is estimated to be 27,286 gpd during this period.

j. No influent reading taken due to power outage. Based on historical data and worst-case scenario calculations, the influent flow is estimated to be $51,347 \mathrm{gpd}$ during this period. 
The following tables (Tables C-2 through C-5) represent hardcopies of the electronic WLAP data files required by the DEQ (DEQ 2002a). Section 5, "Electronic Data Entry," of DEQ 2002a, states "assemble data tables (electronic tables) with other parts of the annual report." The following tables were first compiled as worksheets within the WLAP Data Entry for LA-115-2.xls file using Microsoft Excel 97. The individual worksheets were saved as text files and incorporated as tables in this appendix. Other than formatting to fit the page, and tabulating the data columns, no other formatting was performed. Columns for those parameters not required by the permit are not included in the tables, nor are rejected results shown in these data tables. 
Table C-2. Hydraulic Worksheet from WLAP Data Entry for LA-115-2.XLS

LAND APPLICATION OF WASTEWATER PROGRAM

ANNUAL REPORT FORMS

For Reporting Year -> 2002-2003

WLAP Permit No.--> LA-000115-02

Software and Version no.:-----> MS Excel 97 SR-2

HYDRAULIC APPLICATION RATE

\begin{tabular}{|c|c|c|c|c|}
\hline & & & & Suppl \\
\hline & Month & Manage- & WW & Irrig W \\
\hline Permit & (use 15th & ment & Applied & Applied \\
\hline No. & as date) & Unit & $(\mathrm{MG})$ & (MG) \\
\hline permitno & month & mangunit & wwapp & irrwapp \\
\hline LA-000115 & $11 / 15 / 02$ & MU-011501 & 0.21 & \\
\hline LA-000115 & $12 / 15 / 02$ & MU-011501 & 0.261 & \\
\hline LA-000115 & $01 / 15 / 03$ & MU-011501 & 0.219 & \\
\hline LA-000115 & $02 / 15 / 03$ & MU-011501 & 0.16 & \\
\hline LA-000115 & $03 / 15 / 03$ & MU-011501 & 0.127 & \\
\hline LA-000115 & $04 / 15 / 03$ & MU-011501 & 0.069 & \\
\hline LA-000115 & $05 / 15 / 03$ & MU-011501 & 0.081 & \\
\hline LA-000115 & $06 / 15 / 03$ & MU-011501 & 0.152 & \\
\hline LA-000115 & $07 / 15 / 03$ & MU-011501 & 0.142 & \\
\hline LA-000115 & $08 / 15 / 03$ & MU-011501 & 0.189 & \\
\hline LA-000115 & $09 / 15 / 03$ & MU-011501 & 0.133 & \\
\hline LA-000115 & $10 / 15 / 03$ & MU-011501 & 0.175 & \\
\hline LA-000115 & $11 / 15 / 02$ & MU-011502 & 0.223 & \\
\hline LA-000115 & $12 / 15 / 02$ & MU-011502 & 0.277 & \\
\hline LA-000115 & $01 / 15 / 03$ & MU-011502 & 0.165 & \\
\hline LA-000115 & $02 / 15 / 03$ & MU-011502 & 0.191 & \\
\hline LA-000115 & $03 / 15 / 03$ & MU-011502 & 0.135 & \\
\hline LA-000115 & $04 / 15 / 03$ & MU-011502 & 0.032 & \\
\hline LA-000115 & $05 / 15 / 03$ & MU-011502 & 0.01 & \\
\hline LA-000115 & $06 / 15 / 03$ & MU-011502 & 0.105 & \\
\hline LA-000115 & $07 / 15 / 03$ & MU-011502 & 0.213 & \\
\hline LA-000115 & $08 / 15 / 03$ & MU-011502 & 0.248 & \\
\hline LA-000115 & $09 / 15 / 03$ & MU-011502 & 0.123 & \\
\hline LA-000115 & $10 / 15 / 03$ & MU-011502 & 0.201 & \\
\hline LA-000115 & $11 / 15 / 02$ & MU-011503 & 0.285 & \\
\hline LA-000115 & $12 / 15 / 02$ & MU-011503 & 0.238 & \\
\hline LA-000115 & $01 / 15 / 03$ & MU-011503 & 0.165 & \\
\hline LA-000115 & $02 / 15 / 03$ & MU-011503 & 0.171 & \\
\hline LA-000115 & $03 / 15 / 03$ & MU-011503 & 0.071 & \\
\hline LA-000115 & $04 / 15 / 03$ & MU-011503 & 0.061 & \\
\hline LA-000115 & $05 / 15 / 03$ & MU-011503 & 0.031 & \\
\hline LA-000115 & $06 / 15 / 03$ & MU-011503 & 0.112 & \\
\hline LA-000115 & $07 / 15 / 03$ & MU-011503 & 0.109 & \\
\hline LA-000115 & $08 / 15 / 03$ & MU-011503 & 0.117 & \\
\hline LA-000115 & $09 / 15 / 03$ & MU-011503 & 0.228 & \\
\hline LA-000115 & $10 / 15 / 03$ & MU-011503 & 0.289 & \\
\hline LA-000115 & $11 / 15 / 02$ & MU-011504 & 0.276 & \\
\hline LA-000115 & $12 / 15 / 02$ & MU-011504 & 0.257 & \\
\hline LA-000115 & $01 / 15 / 03$ & MU-011504 & 0.266 & \\
\hline LA-000115 & $02 / 15 / 03$ & MU-011504 & 0.145 & \\
\hline LA-000115 & $03 / 15 / 03$ & MU-011504 & 0.085 & \\
\hline LA-000115 & $04 / 15 / 03$ & MU-011504 & 0.021 & \\
\hline LA-000115 & $05 / 15 / 03$ & MU-011504 & 0.033 & \\
\hline LA-000115 & $06 / 15 / 03$ & MU-011504 & 0.11 & \\
\hline LA-000115 & $07 / 15 / 03$ & MU-011504 & 0.091 & \\
\hline LA-000115 & $08 / 15 / 03$ & MU-011504 & 0.182 & \\
\hline LA-000115 & $09 / 15 / 03$ & MU-011504 & 0.169 & \\
\hline LA-000115 & $10 / 15 / 03$ & MU-011504 & 0.175 & \\
\hline
\end{tabular}


Table C-2. (continued).

HYDRAULIC APPLICATION RATE

Note: 1. Dates here denote each month of the year.

2. These dates by convention shall be the 15 th of the month.

3 . Each twelve month cycle is repeated for each management unit.

4. If the management unit was not used for land application, enter all zeros.

5. For monthly date, use date function.

6 . Do not change any protected cell.

3. Make sure units for data entered are consistent with units specified in column headings. 
Table C-3. Groundwater Worksheet from WLAP Data Entry for LA-115-2.XLS

LAND APPLICATION OF WASTEWATER PROGRAM

ANNUAL REPORT FORMS

For Reporting Year -> 2002-2003

WLAP Permit No.--> LA-000115-02

Software and Version no.:-----> MS Excel 97 SR-2

Ground Water Quality Data

\begin{tabular}{|c|c|c|c|c|c|c|c|c|c|c|c|}
\hline & & & & Static & & & & & & & \\
\hline & & & & Water & & & & & & fecal & total \\
\hline Permit & Sample & Sampling & Well & Level & chloride & nitrate & ammonium & TDS & BOD & coli & coli \\
\hline No. & Date & Station & ID & (feet) & (ppm) & (ppm) & (ppm) & (ppm) & (ppm) & (count) & (count) \\
\hline permitno & smpldate & station & wellid & wtrdepth & chloride & nitrate & ammonia & tds & bod & fecalcoli & totalcoli \\
\hline LA-000115 & $04 / 15 / 03$ & 03N 30E 19bda01 & GW-011502 & 61.55 & 91.0 & 10.8 & -0.100 & 422 & 3.8 & 0 & 0 \\
\hline LA-000115 & $04 / 14 / 03$ & 03N 30E 19cac01 & GW-011501 & 457.26 & 31.3 & 3.7 & -0.100 & 261 & 2.5 & 0 & 0 \\
\hline LA-000115 & $04 / 14 / 03$ & $03 \mathrm{~N} 30 \mathrm{E} 19 \mathrm{cac} 01$ & GW-011501 & 457.26 & 31.5 & 3.7 & -0.100 & 214 & 2.8 & 0 & 0 \\
\hline LA-000115 & $04 / 15 / 03$ & $03 \mathrm{~N} 30 \mathrm{E} 18 \mathrm{ccc} 01$ & GW-011503 & 460.92 & 12.2 & 0.70 & -0.100 & 178 & 3.0 & 0 & 0 \\
\hline LA-000115 & $10 / 08 / 02$ & 03N 30E 19bda01 & GW-011502 & 63.8 & 139 & 5.8 & -0.100 & 569 & -2.0 & 2 & 500 \\
\hline LA-000115 & $10 / 21 / 02$ & 03N 30E 19cac01 & GW-011501 & 459.32 & 25.8 & 2.7 & -0.100 & 254 & -2.0 & 0 & 0 \\
\hline LA-000115 & $10 / 21 / 02$ & 03N 30E 19cac01 & GW-011501 & 459.32 & 25.8 & 2.6 & -0.100 & 257 & -2.0 & 0 & 0 \\
\hline LA-000115 & $10 / 08 / 02$ & $03 \mathrm{~N} 30 \mathrm{E} 18 \mathrm{ccc} 01$ & GW-011503 & 460.94 & 12.0 & 0.70 & -0.100 & 219 & -2.0 & 0 & 0 \\
\hline
\end{tabular}


Table C-3. (continued).

Ground Water Quality Data

\begin{tabular}{|l|l|l|l|l|l|l|l|l|}
\hline & & & Static & & & \\
\hline & & & & Water & total & & & \\
\hline Permit & Sample & Sampling & Well & Level & phos & TKN & nitrite & \\
\hline No. & Date & Station & ID & (feet) & (ppm) & (ppm) & $(\mathrm{ppm})$ & \\
\hline permitno & smpldate & station & wellid & wtrdepth & phostot & tkn & nitrite & well name \\
\hline LA-000115 & $04 / 15 / 03$ & 03N 30E 19bda01 & GW-011502 & 61.55 & 2.1 & -0.90 & -0.10 & ICPP-MON-PW-024 \\
\hline LA-000115 & $04 / 14 / 03$ & 03N 30E 19cac01 & GW-011501 & 457.26 & 0.068 & -0.90 & -0.10 & USGS-52 \\
\hline LA-000115 & $04 / 14 / 03$ & 03N 30E 19cac01 & GW-011501 & 457.26 & 0.085 & -0.90 & -0.10 & USGS-52 (duplicate) \\
\hline LA-000115 & $04 / 15 / 03$ & 03N 30E 18ccc01 & GW-011503 & 460.92 & 0.077 & -0.90 & -0.10 & USGS-121 \\
\hline & & & & & & & \\
\hline LA-000115 & $10 / 08 / 02$ & 03N 30E 19bda01 & GW-011502 & 63.8 & 2.4 & -1.00 & -0.10 & ICPP-MON-PW-024 \\
\hline LA-000115 & $10 / 21 / 02$ & 03N 30E 19cac01 & GW-011501 & 459.32 & -0.10 & -1.00 & -0.10 & USGS-52 \\
\hline LA-000115 & $10 / 21 / 02$ & 03N 30E 19cac01 & GW-011501 & 459.32 & -0.10 & -1.00 & -0.10 & USGS-52 (duplicate) \\
\hline LA-000115 & $10 / 08 / 02$ & 03N 30E 18ccc01 & GW-011503 & 460.94 & -0.10 & -1.00 & -0.10 & USGS-121 \\
\hline
\end{tabular}

1. If a parameter was analyzed but not detected, put the method detection limit (MDL) preceeded by a minus (-) sign. Contact your laboratory for the MDL if not known.a -1.0

2. If a parameter was not analyzed, leave blank

3. Make sure units for data entered are consistent with units specified in column headings.

4. Bacteria are plate counts; $\mathrm{pH}$ in standard units; $\mathrm{sp}$ cond in umhos $/ \mathrm{cm}$; gross alpha \& beta in $\mathrm{pCi} / \mathrm{L}$.

5. Alkalinity should be expressed as $\mathrm{CaCO} 3$; static water level in feet.

6. For Date field, utilize date cell.

7. All columns are formated for appropriate decimal places- do not modify.

8. Sample methods are listed in the DEQ "Handbook for Land Application of Municipal and Industrial Wasteawter", April 1996, page IV-99-1 through 10.

9. Do not change any protected cell. You may add parameters on right hand side of spreadsheet if needed. You may hide columns that are not typically used 
Table C-4. Wastewater Worksheet from WLAP Data Entry for LA-115-2.XLS

LAND APPLICATION OF WASTEWATER PROGRAM

ANNUAL REPORT FORMS

For Reporting Year -> 2002-2003

WLAP Permit No.--> LA-000115-02

Software and Version no.:-----> MS Excel 97 SR-2

Wastewater Quality Data

\begin{tabular}{|c|c|c|c|c|c|c|c|c|c|c|c|}
\hline & & Sampling & total & sp cond & & & total & & & & No3-N + \\
\hline Permit & Sample & Location & coli & (umhos/ & chloride & TKN & phos & TSS & TDS & BOD & No2-N \\
\hline No. & Date & (Station) & (count) & $\mathrm{cm})$ & (ppm) & (ppm) & (ppm) & (ppm) & (ppm) & (ppm) & (ppm) \\
\hline permitno & smpldate & station & wwtotalc & wwspcond & wwchloride & wwtkn & wwphostot & wwtss & wwtds & wwbod & wwnnn \\
\hline LA-000115 & $11 / 20 / 02$ & WW-011501 & & & & 27.2 & 3.75 & 228 & & 81 & 0.096 \\
\hline LA-000115 & $12 / 03 / 02$ & WW-011501 & & & & 36.2 & 5.05 & 260 & & 137 & 0.209 \\
\hline LA-000115 & $01 / 29 / 03$ & WW-011501 & & & & 29.2 & 5.87 & 236 & & 169 & 0.302 \\
\hline LA-000115 & $02 / 19 / 03$ & WW-011501 & & & & 48.5 & 5.12 & 132 & & 137 & 0.365 \\
\hline LA-000115 & $03 / 25 / 03$ & WW-011501 & & & & 36.4 & 5.79 & 133 & & 135 & 0.309 \\
\hline LA-000115 & $04 / 16 / 03$ & WW-011501 & & & & 36.8 & 5.35 & 195 & & 180 & 0.245 \\
\hline LA-000115 & $05 / 15 / 03$ & WW-011501 & & & & 68 & 8.79 & 280 & & 365 & 0.144 \\
\hline LA-000115 & $06 / 11 / 03$ & WW-011501 & & & & 46.5 & 6.92 & 163 & & 879 & 0.21 \\
\hline LA-000115 & $07 / 08 / 03$ & WW-011501 & & & & 65 & 6.17 & 55.2 & & 122 & 0.073 \\
\hline LA-000115 & $07 / 08 / 03$ & WW-011501 & & & & 65.4 & 6.56 & 92.2 & & 121 & 0.071 \\
\hline LA-000115 & $08 / 14 / 03$ & WW-011501 & & & & 52.9 & 5.83 & 175 & & 255 & 0.133 \\
\hline LA-000115 & $09 / 03 / 03$ & WW-011501 & & & & 41.9 & 6.32 & 164 & & 162 & 0.073 \\
\hline LA-000115 & $10 / 01 / 03$ & WW-011501 & & & & 73.4 & 10.4 & 388 & & 534 & 0.156 \\
\hline LA-000115 & $11 / 20 / 02$ & WW-011502 & & 918.2 & 136 & 12.5 & 3.64 & 18.6 & 483 & 10.9 & 3.2 \\
\hline LA-000115 & $11 / 21 / 02$ & WW-011502 & 1580 & & & & & & & & \\
\hline LA-000115 & $12 / 03 / 02$ & WW-011502 & & 874.5 & 154 & 14 & 3.14 & 107 & 663 & 9.23 & 3.61 \\
\hline LA-000115 & $12 / 04 / 02$ & WW-011502 & 940 & & & & & & & & \\
\hline LA-000115 & $01 / 29 / 03$ & WW-011502 & 2700 & & & & & & & & \\
\hline LA-000115 & $01 / 29 / 03$ & WW-011502 & & 736 & 86.1 & 13.3 & 3.21 & 7.5 & 359 & 8.74 & 3 \\
\hline LA-000115 & $02 / 19 / 03$ & WW-011502 & 4300 & & & & & & & & \\
\hline LA-000115 & $02 / 19 / 03$ & WW-011502 & & 651 & 70 & 15.5 & 2.98 & 12.8 & 296 & 17.9 & 2.24 \\
\hline LA-000115 & $03 / 25 / 03$ & WW-011502 & & 592.8 & 69 & 27.8 & 3.09 & 47.5 & 349 & 19.3 & 1.16 \\
\hline
\end{tabular}


Table C-4. (continued).

Wastewater Quality Data

\begin{tabular}{|c|c|c|c|c|c|c|c|c|c|c|c|}
\hline & & Sampling & total & sp cond & & & total & & & & No3-N + \\
\hline Permit & Sample & Location & coli & (umhos/ & chloride & TKN & phos & TSS & TDS & BOD & No2-N \\
\hline No. & Date & (Station) & (count) & $\mathrm{cm})$ & $(\mathrm{ppm})$ & $(\mathrm{ppm})$ & $(\mathrm{ppm})$ & $(\mathrm{ppm})$ & $(\mathrm{ppm})$ & $(\mathrm{ppm})$ & $(\mathrm{ppm})$ \\
\hline permitno & smpldate & station & wwtotalc & wwspcond & wwchloride & wwtkn & wwphostot & wwtss & wwtds & wwbod & wwnnn \\
\hline LA-000115 & $03 / 26 / 03$ & WW-011502 & 8000 & & & & & & & & \\
\hline LA-000115 & $04 / 16 / 03$ & WW-011502 & 3000 & 632.7 & 78.2 & 7.7 & 3.02 & 27.7 & 450 & 35.6 & 1.09 \\
\hline LA-000115 & $05 / 13 / 03$ & WW-011502 & 50 & & & & & & & & \\
\hline LA-000115 & $05 / 15 / 03$ & WW-011502 & & 686.9 & 97.6 & 13.3 & 3.91 & 25.2 & 451 & 19.2 & 1.12 \\
\hline LA-000115 & $06 / 11 / 03$ & WW-011502 & & 356.3 & 115 & 9.75 & 3.72 & 69.1 & 518 & 387 & 0.099 \\
\hline LA-000115 & $06 / 12 / 03$ & WW-011502 & 700 & & & & & & & & \\
\hline LA-000115 & $07 / 08 / 03$ & WW-011502 & & 877.4 & 151 & 12.7 & 2.95 & 67.8 & 573 & 27.4 & 0.262 \\
\hline LA-000115 & $07 / 08 / 03$ & WW-011502 & & & 152 & 15.1 & 3 & 67 & 574 & 25.4 & 0.268 \\
\hline LA-000115 & $07 / 10 / 03$ & WW-011502 & 100 & & & & & & & & \\
\hline LA-000115 & $08 / 14 / 03$ & WW-011502 & 143 & 1045 & 181 & 12 & 4.19 & 10.6 & 681 & 29 & 0.433 \\
\hline LA-000115 & $09 / 03 / 03$ & WW-011502 & & 997.6 & 173 & 12.1 & 3.97 & 22.6 & 640 & 27.1 & 2 \\
\hline LA-000115 & $09 / 04 / 03$ & WW-011502 & 7900 & & & & & & & & \\
\hline LA-000115 & $10 / 01 / 03$ & WW-011502 & & 960.2 & 162 & 9.97 & 4.29 & 33.5 & 873 & 18.3 & 0.484 \\
\hline LA-000115 & $10 / 02 / 03$ & WW-011502 & 840 & & & & & & & & \\
\hline
\end{tabular}

1. If a parameter was analyzed but not detected, put the method detection limit (MDL) preceeded by a minus (-) sign.. Contact your laboratory for the MDL if it is not known.

2. If a parameter was not analyzed, leave blank.

3. Make sure units for data entered are consistent with units specified in column headings.

4. Bacteria are plate counts; $\mathrm{pH}$ in standard units; sp cond in umhos $/ \mathrm{cm}$; gross alpha \& beta in $\mathrm{pCi} / \mathrm{L}$.

5. Note also that alkalinity should be expressed as $\mathrm{CaCO} 3$.

6. For Date field, utilize a date cell.

7. All columns are formatted for appropriate decimal places - do not modify.

8. Do not change any protected cell. You may add parameter on right hand side of spreadsheet if needed.

9. You may hide columns that are not typically used. 
Table C-5. Site Summary Worksheet from WLAP Data Entry for LA-115-2.XLS

LAND APPLICATION OF WASTEWATER PROGRAM

ANNUAL REPORT FORMS For Reporting Year -> 2002-2003

WLAP Permit No.--> LA-000115-02

Software and Version no.:-----> MS Excel 97 SR-2

Permitted Site Summary

\begin{tabular}{|l|l|l|l|}
\hline & & & $(2)$ \\
\hline & & $(1)$ & WW \\
\hline & Report- & WW & Application \\
\hline Permit & ing & Applied & Season \\
\hline No. & Year & MGA & (days) \\
\hline permitno & repyear & wwgen & wwgenday \\
\hline LA-000115 & 2003 & 7.53 & 365 \\
\hline
\end{tabular}

(1) Total WW applied in million gallons per annum (MGA).

(2) Length of wastewater application season.

1. There should only be one entry for each permit number on this spreadsheet.

2. Make sure units for data entered are consistent with units specified in column headings.

3. All columns are formatted for the appropriate decimal places - do not modify.

4. Do not change any protected cell. 
C-18 


\section{Appendix D \\ Test Area North/Technical Support Facility Sewage Treatment Plant Daily Effluent Flow Readings and Electronic Data Files}


D-2 


\section{Appendix D}

\section{Test Area North/Technical Support Facility Sewage Treatment Plant Daily Effluent Flow Readings and Electronic Data Files}

Table D-1. Test Area North/Technical Support Facility Sewage Treatment Plant daily effluent flows.

\begin{tabular}{|c|c|c|c|}
\hline Date & $\begin{array}{c}\text { Effluent } \\
(\mathrm{WW}-15301) \\
\left(\mathrm{gpd}^{\mathrm{a}}\right)\end{array}$ & Date & $\begin{array}{c}\text { Effluent } \\
(\mathrm{WW}-15301) \\
\left(\mathrm{gpd}^{\mathrm{a}}\right)\end{array}$ \\
\hline $11 / 1 / 2002$ & 7,000 & $11 / 26 / 2002$ & 33,000 \\
\hline $11 / 2 / 2002$ & 13,000 & $11 / 27 / 2002$ & 24,000 \\
\hline $11 / 3 / 2002$ & 12,000 & $11 / 28 / 2002$ & 32,000 \\
\hline $11 / 4 / 2002$ & 30,000 & $11 / 29 / 2002$ & 31,000 \\
\hline $11 / 5 / 2002$ & 41,000 & $11 / 30 / 2002$ & 30,000 \\
\hline $11 / 6 / 2002$ & 26,000 & $12 / 1 / 2002$ & 28,000 \\
\hline $11 / 7 / 2002$ & 23,000 & $12 / 2 / 2002$ & 30,000 \\
\hline $11 / 8 / 2002$ & 31,000 & $12 / 3 / 2002$ & 31,000 \\
\hline $11 / 9 / 2002$ & 21,000 & $12 / 4 / 2002$ & 32,000 \\
\hline $11 / 10 / 2002$ & 28,000 & $12 / 5 / 2002$ & 31,000 \\
\hline $11 / 11 / 2002$ & 5,000 & $12 / 6 / 2002$ & 31,000 \\
\hline $11 / 12 / 2002$ & 17,000 & $12 / 7 / 2002$ & 34,000 \\
\hline $11 / 13 / 2002$ & 23,000 & $12 / 8 / 2002$ & 26,000 \\
\hline $11 / 14 / 2002$ & 11,000 & $12 / 9 / 2002$ & 26,000 \\
\hline $11 / 15 / 2002$ & 16,000 & $12 / 10 / 2002$ & 34,000 \\
\hline $11 / 16 / 2002$ & 20,000 & $12 / 11 / 2002$ & 26,000 \\
\hline $11 / 17 / 2002$ & 27,000 & $12 / 12 / 2002$ & 35,000 \\
\hline $11 / 18 / 2002$ & 21,000 & $12 / 13 / 2002$ & 33,000 \\
\hline $11 / 19 / 2002$ & 30,000 & $12 / 14 / 2002$ & 33,000 \\
\hline $11 / 20 / 2002$ & 30,000 & $12 / 15 / 2002$ & 34,000 \\
\hline $11 / 21 / 2002$ & 31,000 & $12 / 16 / 2002$ & 32,000 \\
\hline $11 / 22 / 2002$ & 19,000 & $12 / 17 / 2002$ & 32,000 \\
\hline $11 / 23 / 2002$ & 25,000 & $12 / 18 / 2002$ & 37,000 \\
\hline $11 / 24 / 2002$ & 29,000 & $12 / 19 / 2002$ & 35,000 \\
\hline $11 / 25 / 2002$ & 25,000 & $12 / 20 / 2002$ & 40,000 \\
\hline
\end{tabular}


Table D-1. (continued).

\begin{tabular}{|c|c|c|c|}
\hline Date & $\begin{array}{c}\text { Effluent } \\
(\mathrm{WW}-15301) \\
\left(\mathrm{gpd}^{\mathrm{a}}\right)\end{array}$ & Date & $\begin{array}{c}\text { Effluent } \\
(\mathrm{WW}-15301) \\
\left(\mathrm{gpd}^{\mathrm{a}}\right)\end{array}$ \\
\hline $12 / 21 / 2002$ & 25,000 & $1 / 21 / 2003$ & 31,000 \\
\hline $12 / 22 / 2002$ & 34,000 & $1 / 22 / 2003$ & 36,000 \\
\hline $12 / 23 / 2002$ & 34,000 & $1 / 23 / 2003$ & 31,000 \\
\hline $12 / 24 / 2002$ & 30,000 & $1 / 24 / 2003$ & 29,000 \\
\hline $12 / 25 / 2002$ & 33,000 & $1 / 25 / 2003$ & 37,000 \\
\hline $12 / 26 / 2002$ & 42,000 & $1 / 26 / 2003$ & 28,000 \\
\hline $12 / 27 / 2002$ & 27,000 & $1 / 27 / 2003$ & 32,000 \\
\hline $12 / 28 / 2002$ & 32,000 & $1 / 28 / 2003$ & 35,000 \\
\hline $12 / 29 / 2002$ & 32,000 & $1 / 29 / 2003$ & 34,000 \\
\hline $12 / 30 / 2002$ & 34,000 & $1 / 30 / 2003$ & 35,000 \\
\hline $12 / 31 / 2002$ & 34,000 & $1 / 31 / 2003$ & 32,000 \\
\hline $1 / 1 / 2003$ & 32,000 & $2 / 1 / 2003$ & 30,000 \\
\hline $1 / 2 / 2003$ & 34,000 & $2 / 2 / 2003$ & 31,000 \\
\hline $1 / 3 / 2003$ & 36,000 & $2 / 3 / 2003$ & 32,000 \\
\hline $1 / 4 / 2003$ & 30,000 & $2 / 4 / 2003$ & 38,000 \\
\hline $1 / 5 / 2003$ & 32,000 & $2 / 5 / 2003$ & 35,000 \\
\hline $1 / 6 / 2003$ & 37,000 & $2 / 6 / 2003$ & 35,000 \\
\hline $1 / 7 / 2003$ & 35,000 & $2 / 7 / 2003$ & 37,000 \\
\hline $1 / 8 / 2003$ & 35,000 & $2 / 8 / 2003$ & 31,000 \\
\hline $1 / 9 / 2003$ & 35,000 & $2 / 9 / 2003$ & 33,000 \\
\hline $1 / 10 / 2003$ & 31,000 & $2 / 10 / 2003$ & 34,000 \\
\hline $1 / 11 / 2003$ & 32,000 & $2 / 11 / 2003$ & 31,000 \\
\hline $1 / 12 / 2003$ & 30,000 & $2 / 12 / 2003$ & 34,000 \\
\hline $1 / 13 / 2003$ & 34,000 & $2 / 13 / 2003$ & 35,000 \\
\hline $1 / 14 / 2003$ & 33,000 & $2 / 14 / 2003$ & 33,000 \\
\hline $1 / 15 / 2003$ & 31,000 & $2 / 15 / 2003$ & 30,000 \\
\hline $1 / 16 / 2003$ & 34,000 & $2 / 16 / 2003$ & 28,000 \\
\hline $1 / 17 / 2003$ & 34,000 & $2 / 17 / 2003$ & 33,000 \\
\hline $1 / 18 / 2003$ & 32,000 & $2 / 18 / 2003$ & 33,000 \\
\hline $1 / 19 / 2003$ & 32,000 & $2 / 19 / 2003$ & 32,000 \\
\hline $1 / 20 / 2003$ & 31,000 & $2 / 20 / 2003$ & 32,000 \\
\hline
\end{tabular}


Table D-1. (continued).

\begin{tabular}{|c|c|c|c|}
\hline Date & $\begin{array}{c}\text { Effluent } \\
(\mathrm{WW}-15301) \\
\left(\mathrm{gpd}^{\mathrm{a}}\right)\end{array}$ & Date & $\begin{array}{c}\text { Effluent } \\
(\mathrm{WW}-15301) \\
\left(\mathrm{gpd}^{\mathrm{a}}\right)\end{array}$ \\
\hline $2 / 21 / 2003$ & 34,000 & $3 / 24 / 2003$ & $3,000^{\mathrm{b}}$ \\
\hline $2 / 22 / 2003$ & 29,000 & $3 / 25 / 2003$ & $4,000^{\mathrm{b}}$ \\
\hline $2 / 23 / 2003$ & 30,000 & $3 / 26 / 2003$ & $4,000^{b}$ \\
\hline $2 / 24 / 2003$ & 33,000 & $3 / 27 / 2003$ & $2,000^{\mathrm{b}}$ \\
\hline $2 / 25 / 2003$ & 33,000 & $3 / 28 / 2003$ & $1,000^{\mathrm{b}}$ \\
\hline $2 / 26 / 2003$ & 43,000 & $3 / 29 / 2003$ & $\mathrm{NR}^{\mathrm{b}, \mathrm{c}}$ \\
\hline $2 / 27 / 2003$ & 33,000 & $3 / 30 / 2003$ & $1,000^{\mathrm{b}}$ \\
\hline $2 / 28 / 2003$ & 26,000 & $3 / 31 / 2003$ & $\mathrm{NR}^{\mathrm{b}}$ \\
\hline $3 / 1 / 2003$ & 33,000 & $4 / 1 / 2003$ & $1,000^{\mathrm{b}}$ \\
\hline $3 / 2 / 2003$ & 30,000 & $4 / 2 / 2003$ & $1,000^{\mathrm{b}}$ \\
\hline $3 / 3 / 2003$ & 35,000 & $4 / 3 / 2003$ & $\mathrm{NR}^{\mathrm{b}}$ \\
\hline $3 / 4 / 2003$ & 30,000 & $4 / 4 / 2003$ & $\mathrm{NR}^{\mathrm{b}}$ \\
\hline $3 / 5 / 2003$ & 30,000 & $4 / 5 / 2003$ & $\mathrm{NR}^{\mathrm{b}}$ \\
\hline $3 / 6 / 2003$ & 35,000 & $4 / 6 / 2003$ & $\mathrm{NR}^{\mathrm{b}}$ \\
\hline $3 / 7 / 2003$ & 32,000 & $4 / 7 / 2003$ & $\mathrm{NR}^{\mathrm{b}}$ \\
\hline $3 / 8 / 2003$ & 28,000 & $4 / 8 / 2003$ & $1,000^{\mathrm{b}}$ \\
\hline $3 / 9 / 2003$ & 33,000 & 4/9/2003 & $\mathrm{NR}^{\mathrm{b}}$ \\
\hline $3 / 10 / 2003$ & 35,000 & $4 / 10 / 2003$ & $\mathrm{NR}^{\mathrm{b}}$ \\
\hline $3 / 11 / 2003$ & 28,000 & $4 / 11 / 2003$ & $\mathrm{NR}^{\mathrm{b}}$ \\
\hline $3 / 12 / 2003$ & 33,000 & $4 / 12 / 2003$ & $1,000^{\mathrm{b}}$ \\
\hline $3 / 13 / 2003$ & 31,000 & $4 / 13 / 2003$ & $\mathrm{NR}^{\mathrm{b}}$ \\
\hline $3 / 14 / 2003$ & 29,000 & $4 / 14 / 2003$ & $\mathrm{NR}^{\mathrm{b}}$ \\
\hline $3 / 15 / 2003$ & 26,000 & $4 / 15 / 2003$ & $\mathrm{NR}^{\mathrm{b}}$ \\
\hline $3 / 16 / 2003$ & 29,000 & $4 / 16 / 2003$ & $\mathrm{NR}^{\mathrm{b}}$ \\
\hline $3 / 17 / 2003$ & 28,000 & $4 / 17 / 2003$ & $1,000^{\mathrm{b}}$ \\
\hline $3 / 18 / 2003$ & 22,000 & $4 / 18 / 2003$ & $\mathrm{NR}^{\mathrm{b}}$ \\
\hline $3 / 19 / 2003$ & $10,000^{\mathrm{b}}$ & $4 / 19 / 2003$ & $1,000^{\mathrm{b}}$ \\
\hline $3 / 20 / 2003$ & $15,000^{\mathrm{b}}$ & $4 / 20 / 2003$ & $\mathrm{NR}^{\mathrm{b}}$ \\
\hline $3 / 21 / 2003$ & $3,000^{\mathrm{b}}$ & $4 / 21 / 2003$ & $2,000^{\mathrm{b}}$ \\
\hline $3 / 22 / 2003$ & $9,000^{\mathrm{b}}$ & $4 / 22 / 2003$ & $\mathrm{NR}^{\mathrm{b}}$ \\
\hline $3 / 23 / 2003$ & $2,000^{\mathrm{b}}$ & $4 / 23 / 2003$ & $\mathrm{NR}^{\mathrm{b}}$ \\
\hline
\end{tabular}


Table D-1. (continued).

\begin{tabular}{|c|c|c|c|}
\hline Date & $\begin{array}{c}\text { Effluent } \\
(\mathrm{WW}-15301) \\
\left(\mathrm{gpd}^{\mathrm{a}}\right)\end{array}$ & Date & $\begin{array}{c}\text { Effluent } \\
(\mathrm{WW}-15301) \\
\left(\mathrm{gpd}^{\mathrm{a}}\right)\end{array}$ \\
\hline $4 / 24 / 2003$ & $\mathrm{NR}^{\mathrm{b}}$ & $5 / 25 / 2003$ & $\mathrm{NR}^{\mathrm{b}}$ \\
\hline $4 / 25 / 2003$ & $\mathrm{NR}^{\mathrm{b}}$ & $5 / 26 / 2003$ & $\mathrm{NR}^{\mathrm{b}}$ \\
\hline $4 / 26 / 2003$ & $\mathrm{NR}^{\mathrm{b}}$ & $5 / 27 / 2003$ & $\mathrm{NR}^{\mathrm{b}}$ \\
\hline $4 / 27 / 2003$ & $\mathrm{NR}^{\mathrm{b}}$ & $5 / 28 / 2003$ & $\mathrm{NR}^{\mathrm{b}}$ \\
\hline $4 / 28 / 2003$ & $\mathrm{NR}^{\mathrm{b}}$ & $5 / 29 / 2003$ & $\mathrm{NR}^{\mathrm{b}}$ \\
\hline $4 / 29 / 2003$ & $\mathrm{NR}^{\mathrm{b}}$ & $5 / 30 / 2003$ & $\mathrm{NR}^{\mathrm{b}}$ \\
\hline $4 / 30 / 2003$ & $\mathrm{NR}^{\mathrm{b}}$ & $5 / 31 / 2003$ & $\mathrm{NR}^{\mathrm{b}}$ \\
\hline $5 / 1 / 2003$ & $\mathrm{NR}^{\mathrm{b}}$ & $6 / 1 / 2003$ & $\mathrm{NR}^{\mathrm{b}}$ \\
\hline $5 / 2 / 2003$ & $\mathrm{NR}^{\mathrm{b}}$ & $6 / 2 / 2003$ & $\mathrm{NR}^{\mathrm{b}}$ \\
\hline $5 / 3 / 2003$ & $\mathrm{NR}^{\mathrm{b}}$ & $6 / 3 / 2003$ & $\mathrm{NR}^{\mathrm{b}}$ \\
\hline $5 / 4 / 2003$ & $\mathrm{NR}^{\mathrm{b}}$ & $6 / 4 / 2003$ & $\mathrm{NR}^{\mathrm{b}}$ \\
\hline $5 / 5 / 2003$ & $\mathrm{NR}^{\mathrm{b}}$ & $6 / 5 / 2003$ & $\mathrm{NR}^{\mathrm{b}}$ \\
\hline $5 / 6 / 2003$ & $\mathrm{NR}^{\mathrm{b}}$ & $6 / 6 / 2003$ & $\mathrm{NR}^{\mathrm{b}}$ \\
\hline $5 / 7 / 2003$ & $\mathrm{NR}^{\mathrm{b}}$ & $6 / 7 / 2003$ & $\mathrm{NR}^{\mathrm{b}}$ \\
\hline $5 / 8 / 2003$ & $\mathrm{NR}^{\mathrm{b}}$ & $6 / 8 / 2003$ & $\mathrm{NR}^{\mathrm{b}}$ \\
\hline $5 / 9 / 2003$ & $\mathrm{NR}^{\mathrm{b}}$ & $6 / 9 / 2003$ & $\mathrm{NR}^{\mathrm{b}}$ \\
\hline $5 / 10 / 2003$ & $\mathrm{NR}^{\mathrm{b}}$ & $6 / 10 / 2003$ & $\mathrm{NR}^{\mathrm{b}}$ \\
\hline $5 / 11 / 2003$ & $\mathrm{NR}^{\mathrm{b}}$ & $6 / 11 / 2003$ & $\mathrm{NR}^{\mathrm{b}}$ \\
\hline $5 / 12 / 2003$ & $1,000^{\mathrm{b}}$ & $6 / 12 / 2003$ & $\mathrm{NR}^{\mathrm{b}}$ \\
\hline $5 / 13 / 2003$ & $\mathrm{NR}^{\mathrm{b}}$ & $6 / 13 / 2003$ & $\mathrm{NR}^{\mathrm{b}}$ \\
\hline $5 / 14 / 2003$ & $\mathrm{NR}^{\mathrm{b}}$ & $6 / 14 / 2003$ & $\mathrm{NR}^{\mathrm{b}}$ \\
\hline $5 / 15 / 2003$ & $\mathrm{NR}^{\mathrm{b}}$ & $6 / 15 / 2003$ & $\mathrm{NR}^{\mathrm{b}}$ \\
\hline $5 / 16 / 2003$ & $\mathrm{NR}^{\mathrm{b}}$ & $6 / 16 / 2003$ & $\mathrm{NR}^{\mathrm{b}}$ \\
\hline $5 / 17 / 2003$ & $\mathrm{NR}^{\mathrm{b}}$ & $6 / 17 / 2003$ & $\mathrm{NR}^{\mathrm{b}}$ \\
\hline $5 / 18 / 2003$ & $\mathrm{NR}^{\mathrm{b}}$ & $6 / 18 / 2003$ & $\mathrm{NR}^{\mathrm{b}}$ \\
\hline $5 / 19 / 2003$ & $\mathrm{NR}^{\mathrm{b}}$ & $6 / 19 / 2003$ & $\mathrm{NR}^{\mathrm{b}}$ \\
\hline $5 / 20 / 2003$ & $\mathrm{NR}^{\mathrm{b}}$ & $6 / 20 / 2003$ & $\mathrm{NR}^{\mathrm{b}}$ \\
\hline $5 / 21 / 2003$ & $\mathrm{NR}^{\mathrm{b}}$ & $6 / 21 / 2003$ & 33,000 \\
\hline $5 / 22 / 2003$ & $\mathrm{NR}^{\mathrm{b}}$ & $6 / 22 / 2003$ & 35,000 \\
\hline $5 / 23 / 2003$ & $\mathrm{NR}^{\mathrm{b}}$ & $6 / 23 / 2003$ & 30,000 \\
\hline $5 / 24 / 2003$ & $\mathrm{NR}^{\mathrm{b}}$ & $6 / 24 / 2003$ & 36,000 \\
\hline
\end{tabular}


Table D-1. (continued).

\begin{tabular}{|c|c|c|c|}
\hline Date & $\begin{array}{c}\text { Effluent } \\
(\mathrm{WW}-15301) \\
\left(\mathrm{gpd}^{\mathrm{a}}\right)\end{array}$ & Date & $\begin{array}{c}\text { Effluent } \\
(\mathrm{WW}-15301) \\
\left(\mathrm{gpd}^{\mathrm{a}}\right)\end{array}$ \\
\hline $6 / 25 / 2003$ & $67,000^{d}$ & $7 / 26 / 2003$ & 35,000 \\
\hline $6 / 26 / 2003$ & 44,000 & $7 / 27 / 2003$ & 37,000 \\
\hline $6 / 27 / 2003$ & $30,000^{\mathrm{e}}$ & $7 / 28 / 2003$ & 36,000 \\
\hline $6 / 28 / 2003$ & $30,000^{\mathrm{e}}$ & $7 / 29 / 2003$ & 45,000 \\
\hline $6 / 29 / 2003$ & 32,000 & $7 / 30 / 2003$ & 42,000 \\
\hline $6 / 30 / 2003$ & 30,000 & $7 / 31 / 2003$ & 41,000 \\
\hline $7 / 1 / 2003$ & 40,000 & $8 / 1 / 2003$ & 44,000 \\
\hline $7 / 2 / 2003$ & 36,000 & $8 / 2 / 2003$ & 30,000 \\
\hline $7 / 3 / 2003$ & 34,000 & $8 / 3 / 2003$ & 37,000 \\
\hline $7 / 4 / 2003$ & 32,000 & $8 / 4 / 2003$ & 36,000 \\
\hline $7 / 5 / 2003$ & 33,000 & $8 / 5 / 2003$ & 42,000 \\
\hline $7 / 6 / 2003$ & 34,000 & $8 / 6 / 2003$ & 48,000 \\
\hline $7 / 7 / 2003$ & 33,000 & $8 / 7 / 2003$ & 38,000 \\
\hline $7 / 8 / 2003$ & 35,000 & $8 / 8 / 2003$ & 40,000 \\
\hline $7 / 9 / 2003$ & 37,000 & $8 / 9 / 2003$ & 35,000 \\
\hline $7 / 10 / 2003$ & 36,000 & $8 / 10 / 2003$ & 36,000 \\
\hline $7 / 11 / 2003$ & 35,000 & $8 / 11 / 2003$ & 37,000 \\
\hline $7 / 12 / 2003$ & 26,000 & $8 / 12 / 2003$ & 40,000 \\
\hline $7 / 13 / 2003$ & 25,000 & $8 / 13 / 2003$ & 39,000 \\
\hline $7 / 14 / 2003$ & 29,000 & $8 / 14 / 2003$ & 38,000 \\
\hline $7 / 15 / 2003$ & 39,000 & $8 / 15 / 2003$ & 45,000 \\
\hline $7 / 16 / 2003$ & 36,000 & $8 / 16 / 2003$ & 38,000 \\
\hline $7 / 17 / 2003$ & 46,000 & $8 / 17 / 2003$ & 39,000 \\
\hline $7 / 18 / 2003$ & 46,000 & $8 / 18 / 2003$ & 41,000 \\
\hline $7 / 19 / 2003$ & 35,000 & $8 / 19 / 2003$ & 43,000 \\
\hline $7 / 20 / 2003$ & 32,000 & $8 / 20 / 2003$ & 47,000 \\
\hline $7 / 21 / 2003$ & 37,000 & $8 / 21 / 2003$ & 50,000 \\
\hline $7 / 22 / 2003$ & 45,000 & $8 / 22 / 2003$ & 43,000 \\
\hline $7 / 23 / 2003$ & 46,000 & $8 / 23 / 2003$ & 39,000 \\
\hline $7 / 24 / 2003$ & 42,000 & $8 / 24 / 2003$ & 39,000 \\
\hline $7 / 25 / 2003$ & 41,000 & $8 / 25 / 2003$ & 45,000 \\
\hline
\end{tabular}


Table D-1. (continued).

\begin{tabular}{|c|c|c|c|}
\hline Date & $\begin{array}{c}\text { Effluent } \\
(\mathrm{WW}-15301) \\
\left(\mathrm{gpd}^{\mathrm{a}}\right)\end{array}$ & Date & $\begin{array}{c}\text { Effluent } \\
(\mathrm{WW}-15301) \\
\left(\mathrm{gpd}^{\mathrm{a}}\right)\end{array}$ \\
\hline $8 / 26 / 2003$ & 40,000 & $9 / 26 / 2003$ & 34,000 \\
\hline $8 / 27 / 2003$ & 46,000 & $9 / 27 / 2003$ & 30,000 \\
\hline $8 / 28 / 2003$ & 44,000 & $9 / 28 / 2003$ & 29,000 \\
\hline $8 / 29 / 2003$ & 43,000 & $9 / 29 / 2003$ & 27,000 \\
\hline $8 / 30 / 2003$ & 39,000 & $9 / 30 / 2003$ & 30,000 \\
\hline $8 / 31 / 2003$ & 37,000 & $10 / 1 / 2003$ & 33,000 \\
\hline $9 / 1 / 2003$ & 38,000 & $10 / 2 / 2003$ & 31,000 \\
\hline $9 / 2 / 2003$ & 39,000 & $10 / 3 / 2003$ & 31,000 \\
\hline $9 / 3 / 2003$ & 42,000 & $10 / 4 / 2003$ & 32,000 \\
\hline $9 / 4 / 2003$ & 42,000 & $10 / 5 / 2003$ & 29,000 \\
\hline $9 / 5 / 2003$ & 43,000 & $10 / 6 / 2003$ & 30,000 \\
\hline $9 / 6 / 2003$ & 42,000 & $10 / 7 / 2003$ & 30,000 \\
\hline $9 / 7 / 2003$ & 41,000 & $10 / 8 / 2003$ & 31,000 \\
\hline $9 / 8 / 2003$ & 40,000 & $10 / 9 / 2003$ & 32,000 \\
\hline $9 / 9 / 2003$ & 40,000 & $10 / 10 / 2003$ & 31,000 \\
\hline $9 / 10 / 2003$ & 41,000 & $10 / 11 / 2003$ & 28,000 \\
\hline $9 / 11 / 2003$ & 34,000 & $10 / 12 / 2003$ & 30,000 \\
\hline $9 / 12 / 2003$ & 32,000 & $10 / 13 / 2003$ & 28,000 \\
\hline $9 / 13 / 2003$ & 28,000 & $10 / 14 / 2003$ & 32,000 \\
\hline $9 / 14 / 2003$ & 30,000 & $10 / 15 / 2003$ & 35,000 \\
\hline $9 / 15 / 2003$ & 29,000 & $10 / 16 / 2003$ & 31,000 \\
\hline $9 / 16 / 2003$ & 33,000 & $10 / 17 / 2003$ & 30,000 \\
\hline $9 / 17 / 2003$ & 32,000 & $10 / 18 / 2003$ & 28,000 \\
\hline $9 / 18 / 2003$ & 33,000 & $10 / 19 / 2003$ & 30,000 \\
\hline $9 / 19 / 2003$ & 29,000 & $10 / 20 / 2003$ & 29,000 \\
\hline $9 / 20 / 2003$ & 29,000 & $10 / 21 / 2003$ & 33,000 \\
\hline $9 / 21 / 2003$ & 30,000 & $10 / 22 / 2003$ & 29,000 \\
\hline $9 / 22 / 2003$ & 27,000 & $10 / 23 / 2003$ & 32,000 \\
\hline $9 / 23 / 2003$ & 33,000 & $10 / 24 / 2003$ & 28,000 \\
\hline $9 / 24 / 2003$ & 26,000 & $10 / 25 / 2003$ & 26,000 \\
\hline $9 / 25 / 2003$ & 35,000 & $10 / 26 / 2003$ & 29,000 \\
\hline
\end{tabular}


Table D-1. (continued).

\begin{tabular}{cc|cc}
\hline Date & $\begin{array}{c}\text { Effluent } \\
(\mathrm{WW-15301)} \\
\left(\mathrm{gpd}^{\mathrm{a}}\right)\end{array}$ & Date & $\begin{array}{c}\text { Effluent } \\
(\mathrm{WW}-15301) \\
\left(\mathrm{gpd}^{\mathrm{a}}\right)\end{array}$ \\
\hline $10 / 27 / 2003$ & 26,000 & $10 / 30 / 2003$ & 29,000 \\
$10 / 28 / 2003$ & 34,000 & $10 / 31 / 2003$ & 31,000 \\
$10 / 29 / 2003$ & 29,000 & & \\
\hline
\end{tabular}

a. gpd-Gallons per day.

b. Effluent flow meter readings are suspect from March 19, 2003, through June 20, 2003, when the flow meter was replaced. Based on historical data and worst-case scenario calculations, the effluent flow is estimated to be 30,400 gpd during this period.

c. NR-No flow reading available.

d. The high flow on June 25, 2003, was the result of a complete water outage occurring on that day, in which all water hydrants were opened to allow for the lines to drain.

e. Effluent flows shown are the average of the flow from June 28, 2003, because no flow readings were taken on June 27, 2003. 
The following tables (Tables D-2 through D-5) represent hardcopies of the electronic WLAP data files required by the DEQ (DEQ 2002a). Section 5, "Electronic Data Entry," of DEQ 2002a, states "assemble data tables (electronic tables) with other parts of the annual report." The following tables were first compiled as worksheets within the WLAP Data Entry for LA-153-1.xls file using Microsoft Excel 97. The individual worksheets were saved as text files and incorporated as tables in this appendix. Other than formatting to fit the page, and tabulating the data columns, no other formatting was performed. Columns for those parameters not required by the permit are not included in the tables, nor are rejected results shown in these data tables. 
Table D-2. Hydraulic Worksheet from WLAP Data Entry for LA-153-1.XLS

LAND APPLICATION OF WASTEWATER PROGRAM

ANNUAL REPORT FORMS

For Reporting Year -> 2002-2003

WLAP Permit No.--> LA-000153-01

Software and Version no.:-----> MS Excel 97 SR-2

HYDRAULIC APPLICATION RATE

\begin{tabular}{|l|l|l|l|l|}
\hline & & & & Suppl \\
\hline & Month & Manage- & WW & Irrig W \\
\hline Permit & (use 15th & ment & Applied & Applied \\
\hline No. & as date) & Unit & (MG) & (MG) \\
\hline permitno & month & mangunit & wwapp & irrwapp \\
\hline LA-000153 & $11 / 15 / 2002$ & MU-015301 & 0.71 & \\
\hline LA-000153 & $12 / 15 / 2002$ & MU-015301 & 1.00 & \\
\hline LA-000153 & $01 / 15 / 2003$ & MU-015301 & 1.02 & \\
\hline LA-000153 & $02 / 15 / 2003$ & MU-015301 & 0.92 & \\
\hline LA-000153 & $03 / 15 / 2003$ & MU-015301 & 0.60 & \\
\hline LA-000153 & $04 / 15 / 2003$ & MU-015301 & 0.01 & \\
\hline LA-000153 & $05 / 15 / 2003$ & MU-015301 & 0.00 & \\
\hline LA-000153 & $06 / 15 / 2003$ & MU-015301 & 0.37 & \\
\hline LA-000153 & $07 / 15 / 2003$ & MU-015301 & 1.15 & \\
\hline LA-000153 & $08 / 15 / 2003$ & MU-015301 & 1.26 & \\
\hline LA-000153 & $09 / 15 / 2003$ & MU-015301 & 1.02 & \\
\hline LA-000153 & $10 / 15 / 2003$ & MU-015301 & 0.94 & \\
\hline
\end{tabular}

Note: 1. Dates here denote each month of the year.

2 . These dates by convention shall be the 15 th of the month.

3. Each twelve month cycle is repeated for each management unit.

4. If the management unit was not used for land application, enter all zeros.

5. For monthly date, use date function.

6. Do not change any protected cell.

3. Make sure units for data entered are consistent with units specified in column headings. 
Table D-3. Groundwater Worksheet from WLAP Data Entry for LA-153-1.XLS

LAND APPLICATION OF WASTEWATER PROGRAM

ANNUAL REPORT FORMS

For Reporting Year -> 2002-2003

WLAP Permit No.--> LA-000153-01

Software and Version no.:-----> MS Excel 97 SR-2

Ground Water Quality Data

\begin{tabular}{|c|c|c|c|c|c|c|c|c|c|c|c|c|}
\hline & & & & Static & & & & & & & & \\
\hline & & & & Water & & & & & & & & \\
\hline Permit & Sample & Sampling & Well & Level & sulfate & chloride & nitrate & ammonium & $\mathrm{Fe}$ & $\mathrm{Mn}$ & $\mathrm{Na}$ & TDS \\
\hline No. & Date & Station & ID & (feet) & (ppm) & $(\mathrm{ppm})$ & $(\mathrm{ppm})$ & (ppm) & $(\mathrm{ppm})$ & (ppm) & (ppm) & (ppm) \\
\hline permitno & smpldate & station & wellid & wtrdepth & sulfate & chloride & nitrate & ammonia & irontotal & mangtotal & sodium & tds \\
\hline LA-000153 & $04 / 21 / 03$ & 06N 31E 14aad01 & GW-015301 & 206.31 & 32.8 & 121 & 0.83 & -0.10 & 0.0356 & -0.0025 & 7.56 & 248 \\
\hline LA-000153 & $04 / 21 / 03$ & 06N 31E 14dad01 & GW-015304 & 210.73 & 13.3 & 3.6 & 0.48 & -0.10 & 0.172 & 0.0039 & 5.49 & 225 \\
\hline LA-000153 & $04 / 21 / 03$ & 06N 31E 14dad01 & GW-015304 & 210.73 & 13.4 & 3.1 & 0.51 & -0.10 & 0.158 & 0.0034 & 5.56 & 216 \\
\hline LA-000153 & $04 / 16 / 03$ & 06N 31E 13cba01 & GW-015303 & 206.93 & 39.6 & 101 & 1.1 & -0.10 & 0.433 & 0.0082 & 51.9 & 424 \\
\hline LA-000153 & $04 / 16 / 03$ & $06 \mathrm{~N} 31 \mathrm{E} 13 \mathrm{cca} 01$ & GW-015302 & 209.35 & 14.2 & 7.2 & 0.40 & -0.10 & 0.0387 & -0.0025 & 5.63 & 147 \\
\hline LA-000153 & $10 / 14 / 03$ & 06N 31E 14aad01 & GW-015301 & 207.96 & 30.8 & 10.9 & 0.79 & -0.10 & 0.0538 & -0.0025 & 7.14 & 225 \\
\hline LA-000153 & $10 / 14 / 03$ & 06N 31E 14dad01 & GW-015304 & 211.41 & 14.0 & 3.3 & 0.50 & -0.10 & 0.0935 & -0.0025 & 5.87 & 196 \\
\hline LA-000153 & $10 / 14 / 03$ & 06N 31E 14dad01 & GW-015304 & 211.41 & 13.6 & 3.2 & 0.52 & -0.10 & 0.0777 & -0.0025 & 5.83 & 188 \\
\hline LA-000153 & $10 / 01 / 03$ & $06 \mathrm{~N} 31 \mathrm{E} 13 \mathrm{cba} 01$ & GW-015303 & 209.79 & 39.5 & 99.6 & 0.83 & -0.10 & 1.07 & 0.0111 & 48.6 & 479 \\
\hline LA-000153 & $10 / 01 / 03$ & $06 \mathrm{~N} 31 \mathrm{E} 13 \mathrm{cca} 01$ & GW-015302 & 209.05 & 13.8 & 3.2 & 0.40 & -0.10 & 0.0932 & -0.0025 & 5.54 & 95 \\
\hline
\end{tabular}

\begin{tabular}{|c|c|c|c|c|c|c|c|c|c|c|c|c|}
\hline & & & & Static & & & & & & & & \\
\hline & & & & Water & & fecal & total & & total & & & \\
\hline Permit & Sample & Sampling & Well & Level & BOD & coli & coli & fluoride & phos & TKN & $\mathrm{Hg}$ & nitrite \\
\hline No. & Date & Station & ID & (feet) & (ppm) & (count) & (count) & (ppm) & (ppm) & (ppm) & (ppm) & (ppm) \\
\hline permitno & smpldate & station & wellid & wtrdepth & bod & fecalcoli & totalcoli & fluoride & phostot & tkn & mercury & nitrite \\
\hline LA-000153 & $04 / 21 / 03$ & 06N 31E 14aad01 & GW-015301 & 206.31 & 2.9 & 0 & 0 & 0.16 & 0.084 & -0.90 & -0.0002 & -0.1 \\
\hline LA-000153 & $04 / 21 / 03$ & 06N 31E 14dad01 & GW-015304 & 210.73 & 2.6 & 0 & 0 & 0.18 & -0.030 & -1.8 & -0.0002 & -0.1 \\
\hline LA-000153 & $04 / 21 / 03$ & 06N 31E 14dad01 & GW-015304 & 210.73 & 2.8 & 0 & 0 & 0.19 & 0.084 & -1.8 & -0.0002 & -0.1 \\
\hline LA-000153 & $04 / 16 / 03$ & $06 \mathrm{~N} 31 \mathrm{E} 13 \mathrm{cba} 01$ & GW-015303 & 206.93 & 3.1 & 0 & 0 & 0.11 & 0.21 & -1.8 & -0.0002 & -0.1 \\
\hline LA-000153 & $04 / 16 / 03$ & $06 \mathrm{~N} 31 \mathrm{E} 13 \mathrm{cca} 01$ & GW-015302 & 209.35 & -2.0 & 0 & 0 & 0.18 & -0.030 & -0.90 & -0.0002 & -0.1 \\
\hline LA-000153 & $10 / 14 / 03$ & 06N 31E 14aad01 & GW-015301 & 207.96 & -2.0 & 0 & 4 & 0.17 & 0.12 & 2.2 & -0.0002 & -0.1 \\
\hline LA-000153 & $10 / 14 / 03$ & 06N 31E 14dad01 & GW-015304 & 211.41 & -2.0 & 0 & 17 & 0.16 & -0.10 & 2.0 & -0.0002 & -0.1 \\
\hline LA-000153 & $10 / 14 / 03$ & 06N 31E 14dad01 & GW-015304 & 211.41 & -2.0 & 0 & 26 & 0.12 & -0.10 & 1.7 & -0.0002 & -0.1 \\
\hline LA-000153 & $10 / 01 / 03$ & $06 \mathrm{~N} 31 \mathrm{E} 13 \mathrm{cba} 01$ & GW-015303 & 209.79 & -2.0 & 0 & 0 & 0.17 & -0.10 & -1.0 & -0.0002 & -0.1 \\
\hline LA-000153 & $10 / 01 / 03$ & $06 \mathrm{~N} 31 \mathrm{E} 13 \mathrm{cca} 01$ & GW-015302 & 209.05 & -2.0 & 0 & 72 & 0.21 & -0.50 & -1.0 & -0.0002 & -0.1 \\
\hline
\end{tabular}


Table D-3. (continued).

Ground Water Quality Data

\begin{tabular}{|c|c|c|c|c|c|c|c|c|c|c|c|}
\hline & & & & Static & & & & & & & \\
\hline & & & & Water & & & & & & & \\
\hline Permit & Sample & Sampling & Well & Level & As & $\mathrm{Cr}$ & $\mathrm{Se}$ & $\mathrm{Ba}$ & $\mathrm{Pb}$ & $\mathrm{Zn}$ & \\
\hline No. & Date & Station & ID & (feet) & (ppm) & (ppm) & (ppm) & (ppm) & (ppm) & (ppm) & \\
\hline permitno & smpldate & station & wellid & wtrdepth & arsenic & chromium & selinium & barium & lead & zinc & well name \\
\hline LA-000153 & $04 / 21 / 03$ & $06 \mathrm{~N} 31 \mathrm{E} 14 \mathrm{aad} 01$ & GW-015301 & 206.31 & -0.0025 & 0.0043 & -0.0025 & 0.0806 & -0.0015 & 0.0506 & TANT-MON-A-001 \\
\hline LA-000153 & $04 / 21 / 03$ & 06N 31E 14dad01 & GW-015304 & 210.73 & 0.0027 & 0.0089 & -0.0025 & 0.0800 & -0.0015 & 0.201 & TANT-MON-A-002 \\
\hline LA-000153 & $04 / 21 / 03$ & 06N 31E 14dad01 & GW-015304 & 210.73 & -0.0025 & 0.0057 & -0.0025 & 0.0796 & -0.0015 & 0.188 & TANT-MON-A-002 (duplicate) \\
\hline LA-000153 & $04 / 16 / 03$ & $06 \mathrm{~N} 31 \mathrm{E} 13 \mathrm{cba} 01$ & GW-015303 & 206.93 & -0.0025 & -0.0025 & -0.0025 & 0.241 & -0.0015 & 0.0291 & TAN-10A \\
\hline LA-000153 & $04 / 16 / 03$ & $06 \mathrm{~N} 31 \mathrm{E} 13 \mathrm{cca} 01$ & GW-015302 & 209.35 & -0.0025 & 0.0044 & -0.0025 & 0.0752 & -0.0015 & 0.171 & TAN-13A \\
\hline LA-000153 & $10 / 14 / 03$ & $06 \mathrm{~N} 31 \mathrm{E}$ 14aad01 & GW-015301 & 207.96 & 0.0027 & 0.0042 & -0.0025 & 0.078 & -0.0015 & 0.0398 & TANT-MON-A-001 \\
\hline LA-000153 & $10 / 14 / 03$ & 06N 31E 14dad01 & GW-015304 & 211.41 & 0.0027 & 0.0079 & -0.0025 & 0.0773 & -0.0015 & 0.107 & TANT-MON-A-002 \\
\hline LA-000153 & $10 / 14 / 03$ & 06N 31E 14dad01 & GW-015304 & 211.41 & 0.0038 & 0.0064 & -0.0025 & 0.0769 & -0.0015 & 0.103 & TANT-MON-A-002 (duplicate) \\
\hline LA-000153 & $10 / 01 / 03$ & 06N 31E 13cba01 & GW-015303 & 209.79 & -0.0025 & -0.0025 & -0.0025 & 0.242 & -0.0015 & 0.0226 & TAN-10A \\
\hline LA-000153 & $10 / 01 / 03$ & $06 \mathrm{~N} 31 \mathrm{E} 13 \mathrm{cca} 01$ & GW-015302 & 209.05 & -0.0025 & 0.0058 & -0.0025 & 0.0748 & -0.0015 & 0.174 & TAN-13A \\
\hline
\end{tabular}

1. If a parameter was analyzed but not detected, put the method detection limit (MDL) preceeded by a minus (-) sign. Contact your laboratory for the MDL if not known.a -1.0

2. If a parameter was not analyzed, leave blank

3. Make sure units for data entered are consistent with units specified in column headings.

4. Bacteria are plate counts; $\mathrm{pH}$ in standard units; sp cond in umhos $/ \mathrm{cm}$; gross alpha \& beta in $\mathrm{pCi} / \mathrm{L}$.

5. Alkalinity should be expressed as $\mathrm{CaCO} 3$; static water level in feet.

6. For Date field, utilize date cell.

7. All columns are formated for appropriate decimal places- do not modify.

8. Sample methods are listed in the DEQ "Handbook for Land Application of Municipal and Industrial Wasteawter", April 1996, page IV-99-1 through 10.

9. Do not change any protected cell. You may add parameters on right hand side of spreadsheet if needed. You may hide columns that are not typically used 
Table D-4. Wastewater Worksheet from WLAP Data Entry for LA-153-1.XLS

LAND APPLICATION OF WASTEWATER PROGRAM

ANNUAL REPORT FORMS

For Reporting Year -> 2002-2003

WLAP Permit No.--> LA-000153-01

Software and Version no.:-----> MS Excel 97 SR-2

Wastewater Quality Data

\begin{tabular}{|c|c|c|c|c|c|c|c|c|c|c|c|}
\hline & & Sampling & total & & & & & total & & & \\
\hline Permit & Sample & Location & coli & chloride & TKN & ammonium & $\mathrm{Na}$ & phos & TSS & TDS & BOD \\
\hline No. & Date & (Station) & (count) & (ppm) & $(\mathrm{ppm})$ & $(\mathrm{ppm})$ & (ppm) & (ppm) & (ppm) & $(\mathrm{ppm})$ & $(\mathrm{ppm})$ \\
\hline permitno & smpldate & station & wwtotalc & wwchloride & wwtkn & wwammonia & wwsodium & wwphostot & wwtss & wwtds & wwbod \\
\hline LA-000153 & $11 / 14 / 02$ & WW-015301 & 80000 & & & & & & & & \\
\hline LA-000153 & $11 / 14 / 02$ & WW-015301 & & 323 & 3.49 & 2.55 & 177 & 0.722 & 13.6 & 798 & 15.2 \\
\hline LA-000153 & $12 / 17 / 02$ & WW-015301 & & 136 & 1.13 & 0.053 & 83 & 2.18 & -4 & 496 & 7.19 \\
\hline LA-000153 & $12 / 17 / 02$ & WW-015301 & & 138 & 1.16 & 0.058 & 83.6 & 2.22 & -4 & 489 & 7.4 \\
\hline LA-000153 & $12 / 19 / 02$ & WW-015301 & 90000 & & & & & & & & \\
\hline LA-000153 & $01 / 15 / 03$ & WW-015301 & & 196 & 2.14 & 0.709 & 122 & 0.557 & 5.3 & 412 & 15.6 \\
\hline LA-000153 & $01 / 15 / 03$ & WW-015301 & & 198 & 2.41 & 0.715 & 120 & 0.566 & 6 & 438 & 13.7 \\
\hline LA-000153 & $01 / 16 / 03$ & WW-015301 & 80000 & & & & & & & & \\
\hline LA-000153 & $02 / 26 / 03$ & WW-015301 & & 108 & 3.53 & 0.405 & 93.4 & 0.207 & -4 & 485 & 8.42 \\
\hline LA-000153 & $02 / 27 / 03$ & WW-015301 & 79000 & & & & & & & & \\
\hline LA-000153 & $03 / 11 / 03$ & WW-015301 & & 245 & 2 & 0.76 & 137 & 0.545 & 5.3 & 962 & 12.1 \\
\hline LA-000153 & $03 / 13 / 03$ & WW-015301 & 80000 & & & & & & & & \\
\hline LA-000153 & $04 / 02 / 03$ & WW-015301 & & 19.3 & 2.49 & 0.544 & 19.1 & 0.536 & 5.1 & 260 & 7.21 \\
\hline LA-000153 & $04 / 03 / 03$ & WW-015301 & 80000 & & & & & & & & \\
\hline LA-000153 & $05 / 20 / 03$ & WW-015301 & & 31.6 & 3.54 & 1.07 & 22.9 & 0.573 & 8.8 & 333 & 10.9 \\
\hline LA-000153 & $05 / 22 / 03$ & WW-015301 & 80000 & & & & & & & & \\
\hline LA-000153 & $06 / 26 / 03$ & WW-015301 & 60000 & & & & & & & & \\
\hline LA-000153 & $06 / 26 / 03$ & WW-015301 & & 19.5 & 8.02 & 0.942 & 8.69 & 0.507 & 8.6 & 264 & 10.6 \\
\hline LA-000153 & $07 / 24 / 03$ & WW-015301 & 53000 & & & & & & & & \\
\hline LA-000153 & $07 / 24 / 03$ & WW-015301 & & 19.3 & 2.73 & 1 & 10.6 & 0.644 & -4 & 262 & 7.19 \\
\hline LA-000153 & $08 / 05 / 03$ & WW-015301 & & 19.6 & 2.05 & 0.698 & 9.67 & 0.555 & 10.1 & 284 & 11.7 \\
\hline LA-000153 & $08 / 07 / 03$ & WW-015301 & 80000 & & & & & & & & \\
\hline LA-000153 & $09 / 17 / 03$ & WW-015301 & 80000 & & & & & & & & \\
\hline LA-000153 & $09 / 18 / 03$ & WW-015301 & & 24.8 & 4.99 & 1.78 & 10.5 & 0.731 & 9.2 & 306 & 7.75 \\
\hline LA-000153 & $10 / 22 / 03$ & WW-015301 & 160000 & & & & & & & & \\
\hline LA-000153 & $10 / 22 / 03$ & WW-015301 & & 47.1 & 3 & 1.06 & 26.1 & 0.755 & 7.7 & 285 & 12.6 \\
\hline
\end{tabular}


Table D-4. (continued).

Wastewater Quality Data

\begin{tabular}{|c|c|c|c|c|c|c|c|c|c|c|c|}
\hline & & Sampling & fecal & & & & nitrate + & & & & \\
\hline Permit & Sample & Location & coli & fluoride & $\mathrm{Fe}$ & $\mathrm{Mn}$ & nitrite & arsenic & barium & chromium & lead \\
\hline No. & Date & (Station) & (count) & (ppm) & (ppm) & (ppm) & (ppm) & (ppm) & $(\mathrm{ppm})$ & (ppm) & (ppm) \\
\hline permitno & smpldate & station & wwfecalc & wwflride & wwiron & wwmn & wwnnn & wwarsenic & wwbarium & wwchrom & wwlead \\
\hline LA-000153 & $11 / 14 / 02$ & WW-015301 & 45000 & & & & & & & & \\
\hline LA-000153 & $11 / 14 / 02$ & WW-015301 & & 0.227 & 0.16 & 0.01 & 3.87 & -0.003 & 0.122 & 0.003 & 0.003 \\
\hline LA-000153 & $12 / 17 / 02$ & WW-015301 & & 0.201 & 0.065 & 0.003 & 1.3 & -0.003 & 0.094 & 0.003 & -0.002 \\
\hline LA-000153 & $12 / 17 / 02$ & WW-015301 & & -0.2 & 0.057 & 0.003 & 1.31 & -0.003 & 0.095 & 0.003 & -0.002 \\
\hline LA-000153 & $12 / 19 / 02$ & WW-015301 & 23000 & & & & & & & & \\
\hline LA-000153 & $01 / 15 / 03$ & WW-015301 & & 0.253 & 0.153 & 0.004 & 4 & -0.003 & 0.097 & 0.003 & -0.002 \\
\hline LA-000153 & $01 / 15 / 03$ & WW-015301 & & 0.247 & 0.155 & 0.004 & 4.01 & -0.003 & 0.098 & 0.003 & -0.002 \\
\hline LA-000153 & $01 / 16 / 03$ & WW-015301 & 5000 & & & & & & & & \\
\hline LA-000153 & $02 / 26 / 03$ & WW-015301 & & 0.276 & 0.137 & 0.005 & 4.09 & -0.003 & 0.092 & 0.003 & 0.001 \\
\hline LA-000153 & $02 / 27 / 03$ & WW-015301 & 5600 & & & & & & & & \\
\hline LA-000153 & $03 / 11 / 03$ & WW-015301 & & 0.23 & 0.184 & 0.005 & 3.84 & 0.003 & 0.114 & -0.003 & -0.0004 \\
\hline LA-000153 & $03 / 13 / 03$ & WW-015301 & 79000 & & & & & & & & \\
\hline LA-000153 & $04 / 02 / 03$ & WW-015301 & & 0.236 & 0.101 & 0.004 & 2.65 & 0.003 & 0.092 & 0.003 & 0.0004 \\
\hline LA-000153 & $04 / 03 / 03$ & WW-015301 & 34000 & & & & & & & & \\
\hline LA-000153 & $05 / 20 / 03$ & WW-015301 & & -0.2 & 0.175 & 0.006 & 3.24 & 0.004 & 0.097 & 0.004 & 0.001 \\
\hline LA-000153 & $05 / 22 / 03$ & WW-015301 & 42000 & & & & & & & & \\
\hline LA-000153 & $06 / 26 / 03$ & WW-015301 & 25000 & & & & & & & & \\
\hline LA-000153 & $06 / 26 / 03$ & WW-015301 & & 0.228 & 0.125 & 0.004 & 3.09 & -0.003 & 0.091 & 0.003 & 0.001 \\
\hline LA-000153 & $07 / 24 / 03$ & WW-015301 & 14000 & & & & & & & & \\
\hline LA-000153 & $07 / 24 / 03$ & WW-015301 & & 0.239 & 0.091 & 0.003 & 4.07 & -0.003 & 0.097 & -0.003 & -0.0004 \\
\hline LA- 000153 & $08 / 05 / 03$ & WW-015301 & & 0.237 & 0.112 & 0.003 & 2.71 & -0.003 & 0.096 & -0.003 & -0.001 \\
\hline LA-000153 & $08 / 07 / 03$ & WW-015301 & 46000 & & & & & & & & \\
\hline LA-000153 & $09 / 17 / 03$ & WW-015301 & 60000 & & & & & & & & \\
\hline LA-000153 & $09 / 18 / 03$ & WW-015301 & & 0.233 & 0.131 & 0.004 & 5.07 & 0.005 & 0.103 & 0.003 & -0.001 \\
\hline LA-000153 & $10 / 22 / 03$ & WW-015301 & 76000 & & & & & & & & \\
\hline LA-000153 & $10 / 22 / 03$ & WW-015301 & & 0.242 & 0.178 & 0.004 & 4.35 & -0.003 & 0.1 & 0.004 & 0.001 \\
\hline
\end{tabular}


Table D-4. (continued).

Wastewater Quality Data

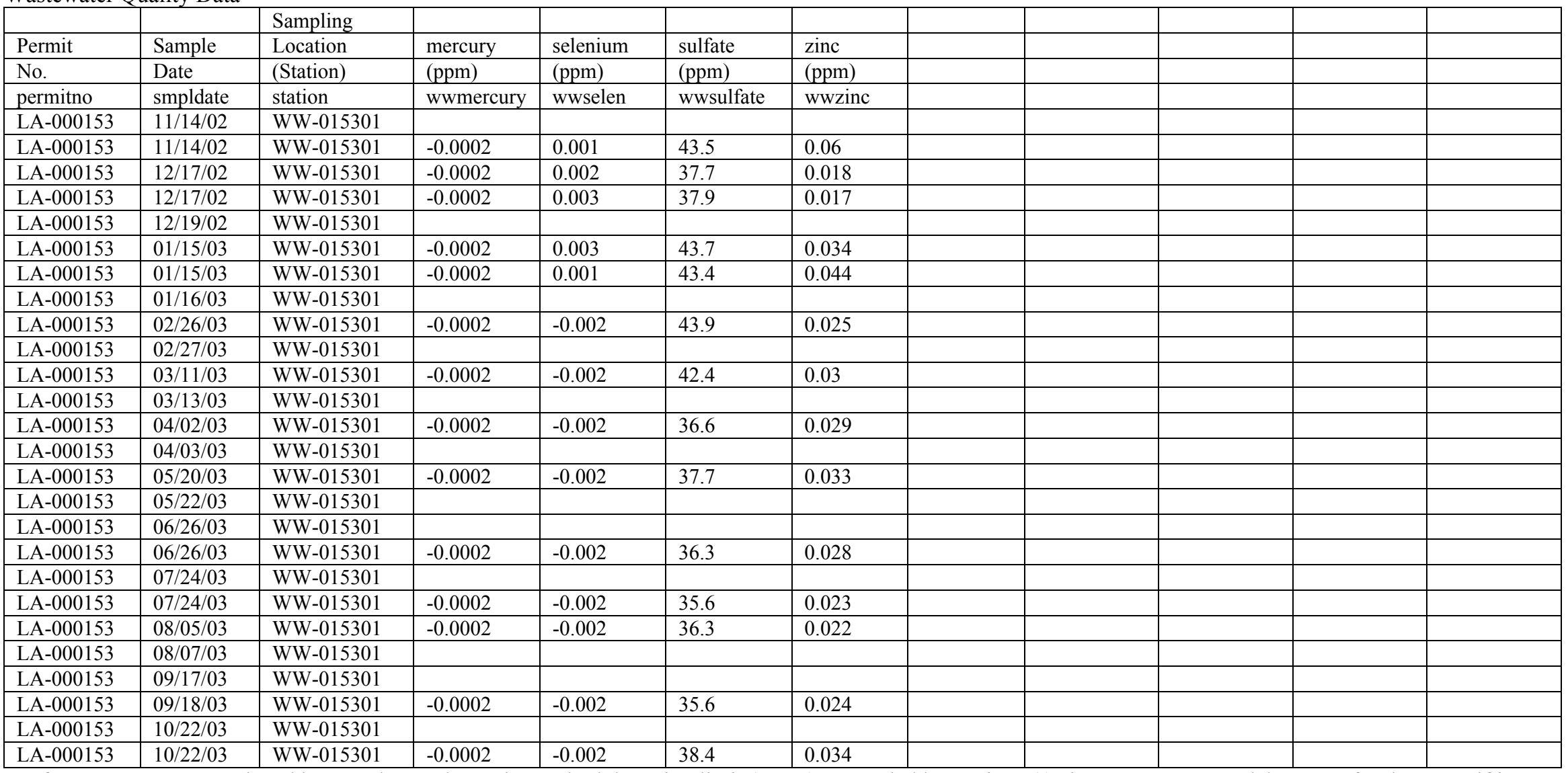

1. If a parameter was analyzed but not detected, put the method detection limit (MDL) preceeded by a minus (-) sign.. Contact your laboratory for the MDL if it is not known.

2. If a parameter was not analyzed, leave blank.

3. Make sure units for data entered are consistent with units specified in column headings.

4. Bacteria are plate counts; $\mathrm{pH}$ in standard units; sp cond in umhos $/ \mathrm{cm}$; gross alpha \& beta in $\mathrm{pCi} / \mathrm{L}$.

5. Note also that alkalinity should be expressed as $\mathrm{CaCO} 3$.

6. For Date field, utilize a date cell.

7. All columns are formatted for appropriate decimal places - do not modify.

8. Do not change any protected cell. You may add parameter on right hand side of spreadsheet if needed.

9. You may hide columns that are not typically used. 
Table D-5. Site Summary Worksheet from WLAP Data Entry for LA-153-1.XLS

LAND APPLICATION OF WASTEWATER PROGRAM

ANNUAL REPORT FORMS

For Reporting Year -> 2002-2003

WLAP Permit No.--> LA-000153-01

Software and Version no.:-----> MS Excel 97 SR-2

Permitted Site Summary

\begin{tabular}{|l|l|l|l|}
\hline & & & $(2)$ \\
\hline & & $(1)$ & WW \\
\hline & Report- & WW & Application \\
\hline Permit & ing & Applied & Season \\
\hline No. & Year & MGA & (days) \\
\hline permitno & repyear & wwgen & wwgenday \\
\hline LA-000153 & 2003 & 8.98 & 365 \\
\hline
\end{tabular}

(1) Total WW applied in million gallons per annum (MGA).

(2) Length of wastewater application season.

1. There should only be one entry for each permit number on this spreadsheet.

2. Make sure units for data entered are consistent with units specified in column headings.

3. All columns are formatted for the appropriate decimal places - do not modify.

4. Do not change any protected cell. 
D-18 